\title{
FREEDOM OF INFORMATION REFORM IN CHINA: INFORMATION FLOW ANALYSIS
}

\author{
by \\ Weibing Xiao, BArts (History) LLM \\ Submitted in fulfilment of the requirements for the Degree of \\ Doctor of Philosophy, \\ University of Tasmania,
}

February 2010 


\section{DECLARATION OF ORIGINAL AUTHORSHIP}

This thesis contains no material which has been accepted for a degree or diploma by the University or any other institution, except by way of background information and duly acknowledged in the thesis, and to the best of the candidate's knowledge and belief no material previously published or written by another person except where due acknowledgement is made in the text of the thesis, nor does the thesis contain any material that infringes copyright.

\section{STATEMENT OF AUTHORITY OF ACCESS}

This thesis may be made available for loan and limited copying in accordance with the Copyright Act 1968 (Cth).

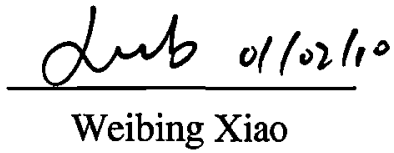

February 2010 


\begin{abstract}
Most non-Chinese scholars have approached Freedom of Information (FOI) in China as a recent, strange and intriguing phenomenon. This thesis uses an array of Chinese sources, interviews with Chinese officials and citizens and information flow analysis to propose a more complex and detailed understanding of the evolution of FOI in China.
\end{abstract}

The thesis argues that information flow, a theme to explore the gradual development of government receptivity to FOI in an information environment through time, can be used as a new explanatory model for FOI reform in a jurisdiction. China serves as an example to substantiate this argument. The origins of China's FOI legislation need to be understood within the context of improved information flow conditions resulting from multifaceted factors, including social, political, legal and economic ones. This improved information flow has constituted an enabling environment for the adoption of FOI legislation.

This thesis also argues that it is necessary to reassess the widely divergent origins of FOI reform in China. By applying information flow analysis, the thesis asserts that social, political and legal factors should be accorded central roles in understanding the development of FOI in China. Economic growth and anti-corruption efforts in the process should be allocated important but secondary roles.

This thesis uses information flow analysis to find that FOI reform in China formed part of a much longer process of increased transparency in the Chinese information environment, which gradually shifted from the acceptance of proactive disclosure to that of reactive disclosure. FOI thus has become a beneficiary of this gradual transformation of the Chinese information environment. This is the reason China has adopted a push model of FOI legislation stressing proactive disclosure of government information, which differs from many countries that have introduced a pull version of FOI legislation emphasising reactive disclosure through responses to access requests. 
The thesis maintains that existing compliance analysis focuses heavily on reactive disclosure, and thus is restricted in its application to China. It therefore utilises a revised compliance analysis model that focuses on both proactive and reactive disclosure. The revised model incorporates findings from empirical research conducted in China, allowing a more effective and dynamic analysis of compliance issues in China. Whilst information flow analysis in this thesis is limited in its application to an explanation of China's FOI phenomenon, it may have wider applicability as it is a dynamic and systematic explanatory framework for FOI. 


\section{ACKNOWLEDGEMENTS}

The work of writing up a doctoral thesis would not have been completed without the support of:

My supervisors, Mr. Rick Snell and Professor Don Chalmers, who constantly supplied me informative and useful commentaries and friendly working environment.

My friends, Paul Hubbard, Rhys Stubbs, Professor Randall Peerenboom and Professor Gino Dal Pont, who made helpful and inspirational comments on my drafts.

Mr. Colin Darch and Professor Peter Underwood, who made a prepublication version of 'Freedom of Information and the Developing World: The Citizen, the State and Models of Openness' available.

My editing team, Dr. Claire Hiller, Andrea Pentecost, Louise Oxley and Morag Porteous, who helped me proofread my thesis and improve my expression.

My employer, Shanghai University of Political Science and Law, who granted me study leave.

My parents, Shuihua Cheng and Xiaoxing Xiao, who sponsored my long journey of study.

My wife, Jing $\mathrm{Li}$, who encouraged me to do $\mathrm{PhD}$ research in abroad and then backed me throughout from every aspect.

I owe gratitude to all of them. 


\section{TABLE OF CONTENTS}

ABSTRACT

ACKNOWLEDGEMENTS $\quad v$

TABLE OF CONTENTS vi

ABBREVIATIONS $\quad x$

LIST OF TABLES

LIST OF FIGURES

1: INTRODUCTION 1

1.0 Introduction 1

1.1 Two explanatory models: accountability deficit and globalisation 2

1.2 Reassessment of FOI reform in China: local information flow conditions 11

1.3 Implementation: a revised compliance analysis model 20

$\begin{array}{ll}1.4 \text { The need for this research } & 27\end{array}$

$\begin{array}{ll}1.5 \text { Aims of research } & 29\end{array}$

$\begin{array}{ll}1.6 \text { Methodology } & 29\end{array}$

1.7 Note on terminology 31

1.8 Chapter summaries $\quad 32$

2: INFORMATION FLOW AS AN ANALYTICAL DEVICE FOR FOI RESEARCH $\quad 34$

2.0 Introduction $\quad 34$

2.1 The reasons for developing an analytical device for FOI research 35

2.2 The basis for developing information flow analysis 37

2.3 Information flow analysis $\quad 41$

2.4 High utility of information flow analysis 44

2.5 Limitations of the application of information flow analysis 48

$\begin{array}{ll}2.6 \text { Conclusion } & 49\end{array}$

3: THE IMTROVED INFORMATIONENVIRONMENT'AS'-A ${ }^{-1}$

RATIONALE FOR FOI REFORM IN CHINA

3.0 Introduction $\quad 50$

3.1 The past: limited information flow in the Chinese information environment 51 
3.2 The present: improved information flow in the Chinese information environment

3.3 A beneficiary of improved information flow: FOI legislation 69

$\begin{array}{ll}3.4 \text { Conclusion } & 70\end{array}$

4: DEMOCRATISATION AS A RATIONALE FOR FOI REFORM IN CHINA $\quad 71$

$\begin{array}{ll}4.0 \text { Introduction } & 71\end{array}$

4.1 A type of FOI emphasising information flow: an acceptable version 72

4.2 Grassroots democracy: an experiment in transparency 83

4.3 Socialist democracy: developing by Openness in Government $\begin{array}{ll}\text { Affairs at all levels } & 87\end{array}$

4.4 FOI legislation: institutionalising Openness in Government Affairs 93

$\begin{array}{ll}4.5 \text { Conclusion } & 95\end{array}$

5: LAW-BASED ADMINISTRATION AS A RATIONALE FOR FOI REFORM IN CHINA $\quad 96$

$\begin{array}{ll}5.0 \text { Introduction } & 96\end{array}$

5.1 Administrative law reforms: improving information flow 97

5.2 Administrative law reforms: a firm basis for FOI legislation $\quad 100$

5.3 FOI legislation: an integral part of law-based administration $\quad 110$

$\begin{array}{ll}5.4 \text { Conclusion } & 112\end{array}$

6: REASSESSMENT OF ECONOMIC GROWTH AND ANTI-CORRUPTION EFFORTS AS RATIONALES FOR FOI REFORM IN CHINA 113

$\begin{array}{ll}6.0 \text { Introduction } & 113\end{array}$

6.1 Reassessing economic development as a rationale for FOI 114

6.2 Reassessing anti-corruption efforts as a rationale for FOI 125

6.3 Conclusion 131

7: GRADUAL LEGISLATIVE PROCESS FOR FOI IN CHINA 132

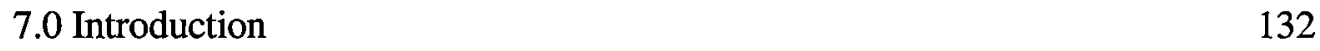

7.1 Openness in Government Affairs: a firm basis for FOI legislation 133

7.2 FOI legislation: developments at the sub-national level 138

7.3 FOI legislation: developments at the national level 141

$\begin{array}{ll}7.4 \text { Conclusion } & 146\end{array}$ 


\section{8: CHINA'S LIMITED PUSH MODEL OF FOI LEGISLATION}

8.0 Introduction

8.1 Models of FOI legislation: pull versus push

8.2 A unique proactive disclosure system: evidence for a push model

8.3 A limited access mechanism

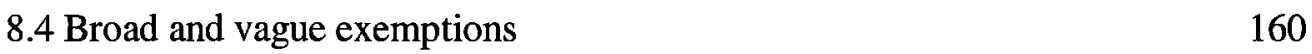

8.5 Omission of the maximum disclosure principle 163

$\begin{array}{ll}8.6 \text { Conclusion } & 164\end{array}$

9: COMPLIANCE WITH PROACTIVE DISCLOSURE REQUIREMENTS IN PRACTICE $\quad 165$

$\begin{array}{ll}9.0 \text { Introduction } & 165\end{array}$

9.1 The supply side: willingness and capability to implement FOI legislation 166

9.2 The supply side: compliance with proactive disclosure in practice 181

9.3 Review systems: increasing the capacity of the demand side to redress non-compliance with proactive disclosure

9.4 The demand side: willingness to redress non-compliance with proactive disclosure

9.5 Conclusion

\section{0: NON-COMPLIANCE WITH REACTIVE DISCLOSURE} REQUIREMENTS IN PRACTICE

10.0 Introduction

10.1 Low willingness from the supply side: a controlling flow approach

10.2 Review systems: limiting the capacity of the demand side to request government information

10.3 The demand side: diverse interests in the use of FOI legislation

10.4 Conclusion

\section{1: CONCLUSION}

11.0 Introduction

11.1 Information flow analysis: explaining the adoption of FOI legislation in China

11.2 Information flow analysis: understanding the implementation of FOI legislation in China

11.3 FOI: moving from a beneficiary to a contributor to the Chinese information environment 
APPENDICES

Appendix 1: Participant information sheet 231

Appendix 2: Consent form 233

Appendix 3: China's Freedom of Information Regulations 234

Appendix 4: FOI legislation in comparatively larger cities 236

Appendix 5: FOI legislation in provinces and special municipalities 236

Appendix 6: FOI proposals submitted by deputies of the National People's Congress

Appendix 7: The main economic indicators in 1978 and in $2007 \quad 237$

Appendix 8: Examples of Chinese citizens' use of FOI legislation 238

Appendix 9: Examples of Chinese journalists' use of FOI legislation 240

Appendix 10: Examples of Chinese legal professionals' use of FOI legislation 241

BIBLIOGRAPHY $\quad 243$

References $\quad 243$

$\begin{array}{ll}\text { Cases } & 279\end{array}$

Legislation $\quad 280$

$\begin{array}{ll}\text { Policy documents } & 283\end{array}$ 
ABBREVIATIONS

CCDI

CPC

FOI

LGNI

LGNOGA

NCCPC

NGOs

NPC

OGA

OTASP

OVA

SARS

SCIO

SMS

WTO
Central Commission for Discipline Inspection

Communist Party of China

Freedom of Information

Leading Group on National Informatisation

Leading Group on National Openness in Government Affairs

National Congress of the Communist Party of China

Non-Government Organisations

National People's Congress

Openness in Government Affairs

Openness in Two Areas and Supervision by the Public Openness in Village Affairs

Severe Acute Respiratory Syndrome

Informatisation Office of the State Council

Short Message Services

World Trade Organisation 


\section{LIST OF TABLES}

Table 1 The Roberts-Snell compliance analysis model 22

Table 2 The use of the Internet and cell phone in China 60

Table 3 The percentage of websites launched by government agencies 67

\section{LIST OF FIGURES}

Figure 1 Information flow in an information environment 42

Figure 2 Limited information flow in the Chinese information environment 52

Figure 3 Improved information flow in the Chinese information environment $\quad 58$

Figure 4 The role of democratisation in improving information flow 83

Figure 5 The role of administrative law reforms in improving information flow 101 


\section{1: INTRODUCTION}

\subsection{Introduction}

China's FOI phenomenon, which refers to the introduction of FOI legislation into mainland China in January 2007, presents a puzzle to the world, demanding explanation and understanding. To solve this puzzle, the following questions need to be clarified. What reasons are there for the adoption of FOI legislation in China? What corresponding legislative process has occurred in China? What type of FOI legislation has been adopted in China? What are the prospects for the implementation of China's FOI legislation? These questions have sparked the research informing this thesis.

'It's FOI, but not as we know it'. 'That was a comment made by an English academic colleague when she spoke with Rick Snell about China's Freedom of Information (FOI) reform some years ago. Friends from different countries, including Australia, Canada, New Zealand, Indonesia, Laos, Malaysia and Nigeria, also raised doubts about the feasibility and effectiveness of FOI legislation in China. They considered Chinese FOI as a 'strange' and 'intriguing' phenomenon. ${ }^{2}$ This phenomenon is regarded as strange because a one-party state like China has not established any of the preconditions - such as liberal democracy, the rule of law, a developed economy, media freedom and an active civil society - normally associated with the easy adoption and implementation of FOI legislation. Non-Chinese academics are further confused by the rapid uptake of FOI legislation in China. The first national FOI legislation was adopted after only five years' consideration from 2002 to 2007 .

\footnotetext{
Rick Snell and Weibing Xiao, 'Freedom of Information Returns to China' (2007) 10 Public Administration Today 44, 47. Ibid 44.
} 
Above all, non-Chinese observers ${ }^{3}$ find it difficult to fully understand China's FOI phenomenon, as it does not fit with the view that FOI is a liberal democratic tool used to limit government power.

This chapter explores two explanatory models normally used to explain the diffusion of FOI, examines the origins and nature of China's FOI reform, explains the need for research, introduces the aims of this research, includes a note on terminology and summarises the remaining chapters.

\subsection{Two explanatory models: accountability deficit and globalisation}

Accountability deficit and globalisation are two common explanatory models for the diffusion of FOI reform. The former is used to explain the wave of FOI before the 1990s in longstanding liberal democracies, such as the US, Australia, New Zealand and Canada. ${ }^{4}$ The latter model is generally used to explain the recent wave of FOI since the 1990 s, especially the 2000 s. ${ }^{5}$ However, both of these explanatory models have limitations when applied to China's FOI phenomenon. The origins of China's FOI legislation need to be understood within the context of improved information flow resulting from changed social, political, legal and economic conditions (see 1.2.3). This improved information flow has constituted an enabling environment for the adoption of FOI legislation. This thesis suggests using information flow analysis (see Chapter 2) to better understand the adoption of FOI in China, and as an improved form of FOI analysis in general.

3 Only a handful of non-Chinese, like Horsley, do not consider China's FOI as a strange phenomenon or paradox. See Jamie Horsley, 'Toward a More Open China?' in Ann Florini (ed), The Right to Know: Transparency for an Open World (2007) 54, 54-91; Jamie Horsley, China Adopts First Nationwide Open Government Information Regulations (2007) Freedom of Information Organisation <http://www.freedominfo.org/features/20070509.htm> at 28 August 2007.

4 Colin Bennett, 'Understanding Ripple Effects: The Cross-National Adoption of Policy Instruments for Bureaucratic Accountability' (1997) 10 Governance: An International Journal of Policy and Administration 213, 213.

5 Thomas Blanton, 'The Openness Revolution: The Rise of a Global Movement for Freedom of Information' (2002) 1 Development Dialogue 7, 16. 


\subsubsection{FOI adoption before the 1990s: a tool for solving accountability deficit}

A dominant theme in the FOI literature, especially before 2000, presupposed two necessary conditions for the adoption of FOI legislation: the perception of growth of government and the development of liberal democracy. ${ }^{6}$ However, this theme has been challenged since the wave of FOI legislation began to spread across many developing countries, including China, Mexico, India, Nepal, Chile and Indonesia, after $2000 .^{7}$

The wave of FOI legislation before the 1990s favoured the argument that FOI was an ingredient to solve a perceived accountability deficit and enhance liberal democracy. ${ }^{8}$ This wave involved countries with long democratic traditions. ${ }^{9}$ While some advanced democracies, such as the UK and Germany, postponed the adoption of FOI legislation until the early 2000 s, they found it increasingly difficult to justify not adopting' this legislation, ${ }^{10}$ especially after the adoption had become a global movement. The fact that most affluent countries have introduced FOI legislation reinforced the notion that FOI was primarily a tool for addressing concerns about the

6 Bennett, above n 4; Colin Bennett, Globalisation and Access to Information Regimes (2001) Access to Information Review Task Force <http://www.atirtf-geai.gc.ca/paper-globalisation1e.html> at 30 January 2008.

$7 \quad$ Alasdair Roberts, Blacked out: Government Secrecy in the Information Age (1 ${ }^{\text {st }}$ ed, 2006) 108-9; Colin Darch and Peter Underwood, Freedom of Information and the Developing World: The Citizen, the State and Models of Openness ( $\left.1^{\text {st }} \mathrm{ed}, 2009\right)$ 13-5.

8 Bennett, above n 4; Roberts argues that these two preconditions only 'capture the realities of the 1970 s and 1980s'. See Roberts, above n 7,107.

9 The world's first FOI law was adopted in Sweden in 1766, although its influences for other FOI adopters were very limited. After the US introduced its FOI legislation in 1966, four countries in the 1970 s and another five in the 1980s followed suit. Denmark, Norway, France and Netherlands adopted their FOI laws in 1970s. Australia, New Zealand, Canada, Greece and Austria adopted their FOI laws in 1980s. See Roger Vleugels, Overview of FOIA Countries Worldwide - February 12006 (2006) State Watch <http://www.statewatch.org/news/2006/feb/foia-feb-2006.pdf> at 3 October 2008.

10 John Ackerman and Irma Sandoval-Ballesteros, 'The Global Explosion of Freedom of Information Laws' (2006) 58 Administrative Law Review 85, 113. 
erosion of government accountability due to expansion of bureaucratic power ${ }^{11}$ and domination of parliaments by the executive. ${ }^{12}$

FOI reform in Australia reflected this need to address an accountability deficit. The traditional methods of accountability based on parliament were inadequate after the government increased its 'impact on the lives of individuals, groups and corporations' over the post-war period. ${ }^{13}$ Missen argued that the executive had too much power, and its 'control over information is a power in itself. Parliament must restore the balance of power and FOI will assist it'. ${ }^{14}$ In addition, question time did not assist members of parliament in acquiring the information they needed. ${ }^{15}$ It was found that 'many members of the Parliament feel themselves unable to fulfil their proper role as elected representatives'. ${ }^{16}$ The accountability deficit and the commitment to liberal democracy were also the origins of FOI legislation in the US, ${ }^{17}$ New Zealand ${ }^{18}$ and Canada. $^{19}$

\subsubsection{FOI adoption after the 1990s: globalisation}

The accountability deficit was an effective explanatory model for the wave of countries adopting FOI legislation before the 1990s. However, FOI newcomers, such

$11 \quad$ Ibid 107-8.

12 Bennett, above n 4, 222.

13 The Australian Attorney-General's Department, Freedom of Information Act 1982 Annual report 1982-1983, 1.2.2; Greg Terrill, 'The Rise and Decline of Freedom of Information in Australia' in Andrew McDonald and Greg Terrill (eds), Open Government: Freedom of Information and Privacy (1998) 89, 90.

14 Alan Missen, 'Freedom of Information - The Australian Experience' (2002) 100 Freedom of Information Review 42, 43.

15 Ibid.

16 The Australian Senate Standing Committee on Constitutional and Legal Affairs, Parliament of Commonwealth, Freedom of Information (1979) [3.14].

17 Ackerman and Sandoval-Ballesteros, above n 10, 116-9.

18 The New Zealand Committee on Official Information observed that one motive for FOI legislation was the concern about the extent of executive powers, arguing that ' $[t]$ he Government has a pervasive involvement in our every day national life ... [and this] circumstances give New Zealanders special reason for wanting to know what their government is doing and why'. See The New Zealand Committee on Official Information, Towards Open Government: General Report (1980) 14; Judith Aitken, 'Open Government in New Zealand' in Andrew McDonald and Greg Terrill (eds), Open Government: Freedom of Information and Privacy (1998) 117, 117.

19 Robert Gillis, 'Freedom of Information and Open Government in Canada' in Andrew McDonald and Greg Terrill (eds), Open Government: Freedom of Information and Privacy (1998) 143, 143-5. 
as Mexico (2002) and India (2005), have focused attention on a different set of explanatory measures. Most of the FOI adopters during the last two decades have very different political and social systems to FOI adopters before the 1990s. They have been prompted by various motives, such as fulfilment of democratic transition, elimination of corruption, protection of human rights, and economic development. ${ }^{20}$ The idea of necessary conditions for FOI reform (see 1.1.1) was refuted by the diffusion of FOI legislation in newly democratic countries in the $1990 \mathrm{~s}^{21}$ and other states in the 2000 s. $^{22}$

An alternative view has been that the FOI movement is being influenced by globalisation. ${ }^{23}$ Globalisation necessitates cross-national learning and emulation, ${ }^{24}$ and drives the introduction of FOI legislation to align with international standards. For Blanton, this is evidence that globalisation, rather than regional varieties, plays a key role in standardising the concept of FOI legislation for 'more value-neutral meanings', ${ }^{25}$ like economic growth. Yet authors, such as Darch, Underwood and Snell, contest the uniformity, necessity or even desirability of this standardisation of response. ${ }^{26}$ Darch and Underwood state that 'the Chinese example ... possibly represents the most serious practical challenge to the idea, implicit in much of the activist literature, that freedom of information procedures are essentially nomothetic, rule-based and universal' ${ }^{27}$ A critique built upon Darch and Underwood's comment is developed in Chapter 6.

20 Roberts, above n 7, 107-11; Blanton, above n 5; Ackerman and Sandoval-Ballesteros, above n 10, 92-3.

21 Roberts argues that the wave of FOI legislation sweeping newly democratic countries in the 1990s began to demonstrate that the argument about the necessary conditions for FOI reform was 'inadequate'. See Roberts, above $n 7,108$. The new democracies introduced FOI legislation as part of their fulfilment of a democratic transition, in contrast to the requirement that affluent democracy should be a precondition for FOI. See Ackerman and Sandoval-Ballesteros, above n 10, 114.

Snell and Xiao, above $n 1,45$.

Blanton, above $\mathrm{n} 5$.

Bennett, above $\mathrm{n} 6$.

Blanton, above $\mathrm{n} 5$.

Darch and Underwood, above n 7, 172; Rick Snell, 'Using Comparative Studies to Improve Freedom of Information Analysis: Insights from Australia, Canada and New Zealand' (Paper presented at Sixth National and Second International Congress on the Right to Information, Mexico, 8-11 November 2005).

27 Darch and Underwood, above n 7, 172. 


\subsubsection{Non-government players: major contributors to FOI reform}

The explanatory models of both accountability deficit and globalisation demonstrate that demand side players, who are information receivers (see 2.3), are key contributors to FOI reform. While domestic players, such as the media and parliament, played significant roles in FOI reform in advanced democracies for addressing the deficit in government accountability, international players, such as the World Bank and the human rights organisation Article 19, have played an increasing role in FOI reform during the last two decades to prompt the idea of a global move in the adoption of FOI legislation. FOI legislation was therefore generally adopted in the hostile circumstances, especially during the wave of FOI legislation before the $1990 \mathrm{~s},{ }^{28}$ which was a largely reactive response to strong pressure from demand side drivers.

\section{Domestic non-government players: FOI adoption before the 1990s}

The diffusion of FOI legislation in advanced democracies suggests that FOI reform is only likely where there is a vigorous campaign ran by non-government players (the media, the Opposition or public interest groups). International players were largely absent from this wave of FOI. As FOI is likely to limit the power of the executive and the bureaucracy, conventional wisdom argues that the government would be more likely to resist such reforms than introduce them. Thus, a common theme, albeit with different emphasis, occurs after the exploration of the comparative development of FOI in countries, such as the US, Australia and New Zealand. ${ }^{29}$ FOI reform in these liberal democracies generally has displayed the following three features: strong pressure from non-government players, adoption by main opposition parties, and

28 Schartum argues that 'an antagonistic relationship between government and citizens fits well with the mode of the 1950s and 1960s, when [FOI] legislation was prepared, and when legislation, to a large extent, came into existence to protect individuals from an ever stronger government'. See Dag Wiese Schartum, 'Information Access Legislation for the Future? Possibilities according to a Norwegian Experience' in Georg Aichholzer and Herbert Burkert (eds), Public Sector Information in the Digital Age. Between Markets, Public Management and Citizens' Rights (2004) 69,78 .

29 Herbert Foerstel, Freedom of Information and the Right to Know: The Origins and Applications of the Freedom of Information Act $\left(1^{\text {st }}\right.$ ed, 2000) 14-26; Terrill, above $\mathrm{n} 13$; Aitken, above $\mathrm{n} 18$. 
various degrees of resistance by the government and/or bureaucracy. ${ }^{30}$ The following two points explain this.

First, the media and members of parliament were significant players on the campaign for FOI in the wave of countries adopting FOI legislation between the 1960s and the 1980s. In the US, both members of Congress and media groups played a key role in prompting the government to consider FOI law. ${ }^{31}$ This was also the case in Australia, the organisation Freedom of Information Legislation Campaign was established in 1976 to promote FOI legislation, ${ }^{32}$ becoming 'the primary pressure group in the campaign which was mounted with varying degrees of intensity through to the passage of the FOI Bill 1981 by the Senate in June 1981'.33

Furthermore, FOI reform was mainly used as an election issue, and thus the Opposition became another major pressure on government to reconsider its predilection for secrecy. In Australia, Senator Evans observed that 'FOI tends to be espoused as a concept rather more passionately by oppositions out of office than by governments sitting in office'. ${ }^{34}$ At the end of the 1972 election campaign, the Opposition Australian Labor Party declared that it would adopt FOI law. ${ }^{35}$ To meet

30 Alasdair Roberts, Limited Access. Assessing the Health of Canada's Freedom of Information Laws (1998) Canadian Newspaper Association <http://www.cna-acj.ca/Client/CNA/cna.nsf/object /LimitedAccess/\$file/limitedaccess.pdf $>$ at 17 November 2006; Rick Snell, 'Administrative Compliance - Evaluating the Effectiveness of Freedom of Information' (2001) 93 Freedom of Information Review 26, 29; Rick Snell, 'FOI and the Delivery of Diminishing Returns, or How Spin-Doctors and Journalists Have Mistreated a Volatile Reform' (2002) 3 The Drawing Board: An Australian Review of Public Affairs 187-203.

31 McCrann observes that '[a] major factor was no doubt the 11 years worth of publicity and pressure engendered by the Moss Subcommittee, as well as the parallel publicity and coverage by the American media'. The Moss Subcommittee was established in 1955 with strong support from Congressman Moss John. See Grace-Ellen McCrann, 'An Examination of the Conditions Surrounding the Passage of the 1966 US Freedom of Information Act' (2007) 1 Open Government: A Journal on Freedom of Information <http://www.opengovjournal.org/article/viewArticle/995> at 22 July 2009; Foerstel, above n 29; Stephen Lamble, Computer-Assisted Reporting and Freedom of Information (D Phil Thesis, Queensland University, 2002) 100-2.

32 Peter Bayne, Freedom of Information: An Analysis of the Freedom of Information Act 1982 (Cth) and a Synopsis of the Freedom of Information Act 1982 (Vic) $\left(1^{\text {st }} \mathrm{ed}, 1984\right) 4$.

33 Ibid 5.

34 Commonwealth, Parliamentary Debates, House of Representatives, 8 April 1981, 1232 (Senator Evans).

35 Gough Whitlam, 'It Is Time for Leadership' (Speech delivered at the Blacktown Civic Centre, Sydney, 13 November 1972). See http://whitlamdismissal.com/speeches/72-11-13 it\%27stime.shtml. 
this election promise, the Cabinet of the first Whitlam government established an Inter-Departmental Committee in 1973 to prepare FOI legislation. ${ }^{36}$ However, the introduction of FOI legislation by the Labor Party was interrupted after Whitlam's dismissal in 1975, and this incomplete task was transferred to the incoming LiberalNational Country Party, which committed to adopt FOI legislation in its 1975 election campaign. ${ }^{37}$

While the FOI Bill was introduced in the Senate in 1978, it lapsed due to the 1980 federal election. About one month before the election, the Fraser government responded to the Senate Committee's Report on Freedom of Information published in $1979 .{ }^{38}$ The FOI Bill was passed by the Senate in 1981 without complete acceptance of significant recommendations by the Senate Committee ${ }^{39}$ Only the Labor Party, the Opposition party at the 1982 federal election, committed to fully implementing the Senate Committee's suggestions. ${ }^{40}$ The Australian Labor Party won the 1982 election, and delivered on its commitment rapidly, passing the first amendment to FOI legislation in October $1983 .^{41}$

In New Zealand, the Opposition also pressured the government to consider FOI legislation. Eagles and others argue that FOI 'became a political issue in New Zealand in the mid-1970s'. ${ }^{42}$ An opposition Labor MP, Richard Prebble, introduced an FOI Bill in 1977, but 'it lapsed after the first reading' ${ }^{43}$ In 1981 , as observed by Aitken, 'the government was under pressure from the opposition Labor Party which was intending to make freedom of information an election issue' ${ }^{44}$ In consequence, the National Party government immediately introduced a bill drafted by the

\footnotetext{
36 Australia, Attorney-General's Department, Proposed Freedom of Information Legislation: Report of Interdepartmental Committee, AGPS, Canberra, 1974, 1.

37 Greg Terrill, Secrecy and Openness: The Federal Government from Menzies to Whitlam and beyond ( $1^{\text {st }}$ ed, 2000) 109 .

38 The Australian Attorney-General's Department, above n 13, 2.7.1; The Senate Standing Committee on Constitutional and Legal Affairs, above $\mathbf{n} 16$.

39 The Australian Attorney-General's Department, above n 38, [2.8].

40 Bayne, above n 32, 6; Terrill, above $n 13$.

41 The Australian Attorney-General's Department, above n 38.

42 Ian Eagles et al, Freedom of Information in New Zealand $\left(1^{\text {st }}\right.$ ed, 1992) 1.

43 Ibid.

44 Aitken, above n 18, 122.
} 
Committee on Official Information into the House of Representatives. ${ }^{45}$ The fact that public servants predominated in the Committee on Official Information was essential to make draft FOI legislation become friendlier toward the supply side/government, which is an information supplier (see 2.3). ${ }^{46}$ This is a notable contrast to the situations in other countries, such as the US, Australia and Canada, where little attention was paid to the capacity of the supply side for FOI reform as their bureaucratic reactions were hostile or at least uninterested. ${ }^{47}$

FOI reform in the US, Australia and Canada ${ }^{48}$ demonstrates that the reform was, to a large extent, 'interparty politics ${ }^{, 49}$ and required significant and active impetus from the Opposition and other players on the demand side, such as the media and public interest groups. Whilst the pressure from demand side players also influenced the adoption of FOI legislation in New Zealand, the New Zealand case indicated that the receptivity of the supply side to FOI was crucial to smooth the adoption and implementation of FOI. This theme is addressed in relation to China in more detail in Chapters 3, 4, 5, 6 and 9.

\section{International players: FOI adoption after the 1990s}

Intergovernmental institutions, international non-government organisations (NGOs) and foreign governments interested in transparency issues ${ }^{50}$ have contributed to the global FOI movement by motivating or pushing many developing states to introduce FOI legislation since the 1990s. This is a notable point of difference with the reform process between the 1960 s and the 1980 s in which international players were largely absent. Several intergovernmental institutions, like the Council of Europe, established a required standard on access to information in early 2000s, which prompted its

45 Eagles et al, above n 42, 2; Aitken, above n 18, 122; Rick Snell, 'The Kiwi Paradox - A Comparison of Freedom of Information in Australia and New Zealand' (2000) 28 Federal Law Review 575, 583.

46 Eagles et al, above n 42, 1; Snell, above n 45, 583; Rick Snell, 'Freedom of Information Practices' (2006) 13 Agenda 291, 297.

Snell, above $n$ 45, 578 .

Gillis, above n 19.

Ackerman and Sandoval-Ballesteros, above n 10, 119.

Roberts, above n 7, 109-10. 
potential members to adopt FOI legislation. ${ }^{51}$ The United Nations Educational Scientific and Cultural Organisation, the United Nations Development Programme, the Organisation of American States and the Pacific Islands Forum Secretariat have also assisted states in introducing FOI legislation. ${ }^{52}$

Some multilateral institutions, including the International Monetary Fund, required the passage of FOI legislation as a prerequisite for further funding, for example the adoption of FOI legislation in Pakistan. ${ }^{53}$ Some international NGOs, such as Transparency International and the Carter Centre, used FOI legislation as a tool for tackling corruption. ${ }^{54}$ NGOs, such as Article 19, the Commonwealth Human Rights Initiatives, the Carter Centre, and the Open Society Justice Initiative, encouraged countries to introduce FOI legislation for protecting the right to know as a fundamental human right. ${ }^{55}$ Foreign governments, including the US, ${ }^{56}$ also

51 Article 19, Promoting Practical Access to Democracy: A Survey of Freedom of Information in Central and Eastern Europe (2002) <http://www.article19.org/pdfs/publications/freedom-ofinformation-survey-of-central-and-e.pdf $>$ at 25 February 2009.

52 Kati Suominen, 'Access to Information in Latin America and the Caribbean' (2003) 2 Comparative Media Law Journal 30, 33. The United Nations Educational Scientific and Cultural Organisation: See http://portal.unesco.org/ci/en/ev.php-URL ID=19488\&URL DO= DOTOPIC \&URL SECTION=201.html; The United Nations Development Programme: http:// www.undp.org/oslocentre/resources/search db dev.html; The Pacific Islands Forum Secretariat: http://www.forumsec.org/pages.cfm/good-governance/good-governance-mechanisms. html.

53 Mukhtar Ahmad Ali, Freedom of Information in South Asia: Comparative Perspectives on Civil Society Initiative (2003) Journalists for Democracy and Human Rights <http://www.jdhr.org/publi cations/papers/Mukhtar\%20A\%20Ali-Media\%20panel-0Edited\%2027.4.pdf > at 25 February 2009. However, Darch and Underwood hold a different view, arguing that there is little evidence which shows that FOI is an explicit policy of these intergovernmental and multilateral institutions. See Darch and Underwood, above n 7,53.

54 Roberts, above n 7, 110; Transparency International's websites: http://www.transparency.org/; The Carter Centre 'continues its anti-corruption programming through the Access to Information Project', stating that 'a focus on Access to Information would serve both to prevent and fight corruption as well as to strengthen overall governance'. See http://www.cartercenter.org/peace/am ericas/anti-corruption.html.

55 See http://www.article19.org/about/index.html; The Commonwealth Human Rights Initiatives' website: http://www.humanrightsinitiative.org/programs/al/rti/rti.htm; The Carter Centre released Atlanta Declaration and Plan of Action for the Advancement of the Right of Access to Information in February 2008, declaring that 'access to information is a fundamental human right'. See http://www.cartercenter.com/documents/Atlanta\%20Declaration\%20and\%20Plan\%20of\%20Actio n.pdf. The Open Society Justice Initiative, Transparency \& Silence: A Survey of Access to Information Laws and Practices in 14 Countries (2006) Open Society Institute \& Soros Foundations Network <http://www.soros.org/resources/articles_publications/publications/transpar ency_20060928/transparency_20060928.pdf> at 12 November 2006.

56 Lamble points out that the US determined to promote FOI through bilateral treaties or agreements in the 1940s. See Stephen Lamble, 'FOI as a United States' Foreign Policy Tool: A Carrot and 
encouraged other countries to adopt FOI legislation by funding international NGOs that collaborated with local demand side players to help catalyse local demand for government information. Cambodia serves as a case in point. ${ }^{57}$

\subsection{Reassessment of FOI reform in China: local information flow conditions}

This thesis argues that the wide diffusion of FOI reform in the last decade across numerous and diverse political and administrative systems may necessitate a rethink about the explanatory models used for FOI reform. In particular, domestic or local information flow conditions over time may justify a higher and more dominate explanatory role (see Chapters 2, 3,4 and 5). The economic growth, globalisation and anti-corruption explanations for FOI reform in China fail to sufficiently account for and identify the significant and constantly evolving changes in the social, political and legal environment. These more traditional explanatory models, in particular, obscure or downplay the importance of improved information flow, which has created an enabling environment for FOI reform in China.

\subsubsection{FOI reform in China: missing liberal democratic elements}

Liberal democratic values, processes and institutions are rarely found in China and the presence of FOI reform in the absence of these elements has caused a quandary for non-Chinese scholars. It is observed that ' $[\mathrm{t}]$ he real paradox of [FOI] in China is its introduction into a non-democratic political system' ${ }^{58}$ Kolhammar also argues that 'it might seem paradoxical that a traditionally authoritarian state such as China is implementing a regulation that is giving citizens greater insight into the dealings of

Stick Approach' (2003) 105 Freedom of Information Review 38, 38-41. The United State Agency for International Development now plays a similar role. See http://www.usaid.gov/.

57 The United State Agency for International Development has funded Pact Cambodia to assist Cambodia to develop a policy paper on FOI since 2007. See http://cambodia.usembassy.gov/usaid monasri mou.html.

58 Paul Hubbard, 'China's Regulations on Open Government Information: Challenges of Nationwide Policy Implementation' (2008) 1 Open Government: A Journal on Freedom of Information <http://www.opengovjournal.org/article/viewArticle/2651> at 22 July 2009. 
the state' ${ }^{59}$ These statements are based on the dominant argument that FOI reform should come later than other fundamental liberal democratic values, which can tolerate FOI. ${ }^{60}$ China, in the absence of these liberal democratic elements, provides a significant and divergent case study in FOI reform (see Chapter 4).

\subsubsection{Globalisation: a follow up to FOI reform rather than a key driver}

In contrast to the claims made by Blanton and others for the integral role of globalisation in FOI reform after the $1990 \mathrm{~s},{ }^{61}$ its role in China has been secondary in terms of importance and timing. Globalisation advocates have stressed the role of emulation, international players and policy convergence in contributing to the spread of FOI reform. ${ }^{62}$ These three factors have played a minor role in China.

First, China's FOI reform was not simply an emulation of 'better-off states' ${ }^{63}$ or liberal democracies (see 4.1.2 and 4.2). Second, whilst the most recent FOI reform saw growing involvement of external assistance, the initial role played by international players, including multilateral organisations and NGOs, was minimal in China. This contrasts with the dominant transparency efforts of international institutions that marked most of the recent FOI adopters in the Asian region. ${ }^{64}$ However, international involvement or cooperation was important in formulating the actual content of FOI legislation in China. The EU-China Information Society Project and the China Law Centre at Yale University provided fora for international

59 Jens Kolhammar, The Challenge to Implement the Open Government Information Regulation in China (2008) China Elections <http://en.chinaelections.org/newsinfo.asp?newsid=17891> at 2 October 2008.

60 Bennett, above n 4, 223.

61 Blanton, above n 5.

62 An implicit assumption by some academics is that globalisation leads to policy convergence. FOI legislation has not been an exception. See Bennett, above n 4; Colin Bennett, 'Review Article: What Is Policy Convergence and What Causes It?' (1991) 21 British Journal of Political Science 215-33.

63 Roberts predicted that one reason for other less wealthy countries to adopt FOI legislation might have been an emulation of 'better-off states'. See Roberts, above n 7, 109.

64 Such as Pakistan and the efforts in Cambodia. Pakistan adopted its FOI legislation to respond to the call of the Asian Development Bank. See David Banisar, Freedom of Information around the World 2006: A Global Survey of Access to Government Information Laws (2006) Freedom of Information Organisation <http://www.freedominfo.org/documents/global_survey2006.pdf > at 9 November 2006. 
cooperation in this area. ${ }^{65}$

Third, policy convergence, as a result of globalisation, was not a significant factor in Chinese FOI reform. Several substantive mechanisms, which are generally advocated and regarded by international players as decisive factors to promote increased transparency, such as the right of everyone to access information, a principle of maximum disclosure, a general public interest test and an independent oversight body ${ }^{66}$ did not surface in China's FOI legislation. Indeed, the only convergence occurred on many of the non-substantive measures, such as forms of requests, partial disclosure, fees for requests, time limits and an annual report. ${ }^{67}$ This partly explains the lukewarm and often negative reception given to the news of FOI reform in China.

China's reform is an example that can be used to support warnings against the dominant notion, which holds that ' $\mathrm{FOI}$ is a readily transplantable law and therefore there is little need for analysis'. ${ }^{68}$ Globalisation fails to provide a satisfactory justification for FOI reform in China. A consideration of FOI reform in China necessitates a search for improved forms of analysis capable of explaining the deviations from expected patterns. Information flow is such an improved form of analysis (See 1.2.3).

\subsubsection{Local information flow conditions: an explanatory model}

The current explanatory models of accountability deficit and globalisation do not explain China's FOI phenomenon, suggesting the need for a new analytical device. Information flow is developed in this thesis as a possible improvement in FOI

65 The EU-China Information Society Project is a 4-year cooperation project between the Chinese government and the EU (2005-2009). Access to government information is its important part. See http://www.eu-china-infso.org/regulations.asp?ClassID $=1$. The China Law Centre at Yale University did not directly contribute to the first national FOI legislation in China. However, it has been involved in legislative processes of local FOI Rules, such as Guangzhou and Shanghai. Email from Jamie Horsley to Weibing Xiao, 6 May 2009.

66 The Open Society Justice Initiative, above n 55; Article 19, Right to Know: Principles on Freedom of Information Legislation $(1999)<\mathrm{http}: / /$ www.article19.org/pdfs/standards/righttoknow. pdf $>$ at 1 July 2007.

67 Freedom of Information Regulations 2007 (China) Art 20, 22, 27, 31.

68 Snell, above n 26. 
analysis. Information flow is a theme that can be used to explore the gradual development of government receptivity to FOI in the Chinese information environment through time. Information flow analysis, which focuses on a historical exploration of the shifting dynamics of the Chinese information environment resulting from social, political, legal and economic factors, has a high explanatory capability for China's FOI phenomenon (see 2.4).

An information flow analysis model builds on, and brings together, multiple strands from several disciplines (see 2.2). Information flow, including flow from the government to citizens and from citizens to government, and flow among governments, and among citizens, is a critical concept to understanding an information environment (see 2.3). Furthermore, as all streams of information flow are correlative, this analysis brings greater flexibility and a more dynamic understanding to the processes involved. An information environment is a complex system where all the key elements impact on, and are impacted by, other elements. Information flow analysis has some capacity to take into account this dynamic interaction (see 2.4.2). It is an analytical framework used in this thesis for examining the improvement of the Chinese information environment that has paved the way for FOI reform in China.

Information flow analysis is first used in this thesis to provide a better understanding and explanation of the changing capacity of the Chinese information environment over time to support or accommodate FOI as an important policy instrument of government. For China, the thesis argues, FOI has become both a beneficiary and important contributor to the transformation of the Chinese information environment assisted by a gradual improvement in information flow conditions over time (see 3.3). Furthermore, information flow analysis can improve existing compliance analysis by focusing on a broad, dynamic and cross-jurisdictional analysis of FOI performance (see 1.3.3). Whilst information flow analysis in this thesis is limited in its application to an explanation of China's FOI phenomenon, it may have wider applicability (see 2.4). 


\subsubsection{Reappraisal of reasons for China's FOI reform}

The social, political, legal and economic context of information flow in recent Chinese history is fundamental to fully understanding the development of FOI in China. Both Chinese and non-Chinese scholars have given China's FOI a primary role in contributing to economic growth ${ }^{69}$ and anti-corruption efforts. ${ }^{70}$ These two driving forces are commonly used to explain the apparent paradox of China's FOI phenomenon, ${ }^{71}$ but this thesis asserts that they have been over-stressed in the existing literature. Close scrutiny of the historical background to the introduction of FOI finds that the new mode of economic growth - informatisation which means the modernisation of China's information technology infrastructure - was used as a means of making FOI reform more politically acceptable, rather than as a primary driving force for FOI reform (see 6.1). Furthermore, the role of the impetus of anticorruption measures for FOI reform should be downplayed, as the link between anticorruption initiatives and FOI appeared late, and the access mechanism was not considered as a primary anti-corruption tool (see 6.2).

There are three other driving forces for China's FOI reform that should receive higher prominence. First, improved information flow lessened the level of information asymmetry in the longstanding secretive Chinese information environment, which in turn increased China's capacity to accept a form of FOI. The relaxation of the Chinese information environment prompted the Chinese government to abandon a secretive and reactive approach to information management, and instead to adopt a more transparent and proactive approach. Under this approach, FOI became a useful

69 Hanhua Zhou, Academic Draft of FOI Regulations (in Chinese) (1 $1^{\text {st }}$ ed, 2003) 19-20; Mingjie Zhang, Open Government: Research on FOI Laws (in Chinese) (1 $1^{\text {st }}$ ed, 2003) 212-3; Blanton, above $\mathrm{n} 5$.

70 Zhengqun Zhao, 'Discussion of Anti-Corruption through Openness in Government Affairs' (in Chinese) (2001) 6 Theory and Modernisation, 51, 54; Roberts, above n 7, 110; Horsley, above n 3; Blanton, above $\mathrm{n} 5$.

71 Darch and Underwood, above n 7, 171; Blanton, above n 5; Toby Mendel, 'Corruption, Access to Information and Human Development' (Draft at 9 August 2008); Graham Sutton and Sarah Holsen, 'China Progresses Information Access and Data Protection Laws' (2006) 2 Open Government: A Journal on Freedom of Information <http://www.opengovjournal.org/article/view/ $621 / 482>$ at 22 July 2009. 
tool in a more open environment. Arguably, the more open environment, rather than crises, including Severe Acute Respiratory Syndrome and the Songhuajiang River contamination, created the necessity for FOI reform (see Chapter 3 ). ${ }^{72}$

Second, China's FOI reform formed part of a wider package of transparency reforms linked to a long term democratisation process. This wider transparency reform package relaxed the secretive Chinese information environment, and this in turn increased the receptivity of the Chinese government to an access mechanism. Openness practices, including Openness in Village Affairs and Openness in Government Affairs (OGA), were first introduced to develop grassroots democracy, a key political reform program for China to gradually develop its socialist democracy (see 4.2). ${ }^{73}$ OGA was extended to a higher level of socialist democracy through developing democratic means (democratic decision-making, management and supervision) and democratic rights (the rights to know, freedom of expression, participate and supervise). These proactive disclosure practices, which preceded FOI, softened the secretive information environment in China. This change gradually increased the Chinese government's receptivity to FOI (see Chapter 4).

Third, three decades of administrative law reforms mellowed the secretive Chinese information environment, thus resulting in the acceptance of FOI in China. After earlier administrative law reforms had moved toward creating effective checks on government power from ex ante and procedural perspectives, the capacity to accept FOI increased. In 2004, the central government's law-based administration initiative associated with administrative law reforms, further contributed to the acceptance of an access mechanism in China (see Chapter 5).

72 Some Chinese scholars observe that after the SARS crisis, the legislative process of FOI was accelerated. Professor Hanhua Zhou, a key member of drafting China's FOI legislation, held this view when he was interviewed by a newspaper reporter of China Youth Daily. See Yijun Wang, 'The Breakthrough of Legislating on FOI after a Decade' (in Chinese) China Youth Daily (Beijing) 25 April 2007, 3. Datong Li, a Chinese Journalist, also held the similar view. See Datong Li, $A n$ End to Exclusivity (2007) Open Democracy <http://www.opendemocracy.net/ node/4585> at 7 March 2009. Darch and Underwood agreed with Li on this. See Darch and Underwood, above n 7 , 178.

73 The CPC Central Committee, Communique of the Fifth Plenary Session of the $15^{\text {th }}$ CPC Central Committee (2000). 


\subsubsection{Internally generated FOI reform}

The Chinese central government initiated and promoted FOI reform in China. ${ }^{74}$ The passage of the first FOI legislation in 2007 became 'another self-revolution' of the government following the adoption of the Administrative Permission Law 2003. ${ }^{75}$ This self-revolution action led to the departure of FOI reform in China from the more typical FOI reform process, creating a problem for non-Chinese academics' understanding of China's FOI phenomenon. Concern has been expressed about the feasibility of this self-revolution action. After all, the initiative in FOI reform has rarely come from the government. ${ }^{76}$ Roberts states that ' $[\mathrm{a}]$ natural question is why the leaders of a one-party state would be eager to (emphasis added) adopt a policy that is usually sold as a tool for limiting governmental power' ${ }^{77}$ Answers to this question require an understanding of China's FOI reform from broader and historical perspectives.

The central role played by the Communist Party of China (CPC) or the Chinese central government is analysed in Chapters 4,5 and 7. Without this support and leadership role, China could not have achieved its historic FOI breakthrough in early 2007. There were several reasons why a particular type of FOI program, which emphasises information flow, was more attractive to the CPC than a pure type of FOI which is closely associated with liberal democracy. Nevertheless, despite this CPC leadership, the adoption of FOI was not universally supported throughout all layers of the Chinese government or all areas of government. The adoption of FOI in China is a rationalist story of many transparency advocates and activities taking place amid the absence of any uniform or strong opposition due to the CPC's support of a

74 Hanhua Zhou, 'Significance and Features of Introducing FOI Legislation in China' (in Chınese) (2007) 6 China Today Forum 29, 30.

75 Weipo Wen, Chinese Scholars Hail Government Information Transparency Regulations (2008) China Elections <http://en.chinaelections.org/newsinfo.asp?newsid=17678> at 2 October 2008.

76 Blanton, above n 5, 7; Ackerman and Sandoval-Ballesteros, above n 10, 121. Snell would argue that New Zealand was a particular and important exception to this assertion. See Snell, above $\mathrm{n} 46$.

77 Alasdair Roberts, Freedom of Information: From Millions to Billions (2008) Sunshine Week $<$ http://www.sunshineweek.org/sunshineweek/roberts08> at 2 October 2008. 
general move toward greater transparency. ${ }^{78}$

FOI reform was invigorated by informatisation agencies in 2002 to develop the new mode of economic growth - informatisation. ${ }^{79}$ This reform was subsequently strengthened by anti-corruption agencies' endeavours to tackle corruption. ${ }^{80}$ Other agencies, such as the State Council Information Office and the State Secrecy Bureau, also made contributions to greater transparency by improving proactive disclosure systems and classification respectively (see 3.2.3 and 6.1.3). Whilst these agencies promoted FOI to further their interests, their direct and indirect efforts assisted in generating favourable consideration of FOI reform by the central government. Their efforts are further explored in Chapters 3 to 7.

In retrospect, rather than being a completely unexpected development in China, FOI was in part a long term policy development that was strongly supported by several key organs of the Chinese government. The feasibility of FOI reform increased with each major development in wider government information policy, practice and changing information flow between government and citizens in China.

\subsubsection{Gradualism: the hallmark of FOI reform}

Gradualism has been the hallmark of political and law reforms in China. ${ }^{81}$ Political and legal tools like FOI have been no exception. Contrary to the external perception that FOI reform in China occurred essentially overnight or in a very limited time period from 2002 to 2007 , the reform formed part of a much longer process of

78 Hanhua Zhou, Speech delivered at Seminar on the Challenges and Possibilities for Government Information Disclosure, Beijing, 25 June 2008. See http://www.gongmeng.cn/sub_r.php?zyj_id=1 774. Horsley in her 'Toward a More Open China?' article states that 'the primary motivating force is domestic dynamics'. See Horsley, above n 3, 54.

79 Explanation Memorandum, The Draft of FOI Regulations 2002 (China) 23.

80 Yong He, 'The Speech of Yong He at the Second Meeting of the Leading Group on National Openness in Government Affairs' (Speech delivered at Beijing, 29 April 2004).

81 Gradualism refers to the belief that changes occur, or ought to occur, slowly in the form of gradual steps. The gradual approach is a key element of Dengism that is a series of political and economic ideologies first developed by Chinese political leader Xiaoping Deng. This theory was written into the CPC's Party Constitution and the preface of the Constitution in 1999. See Xiaoping Deng, Selected Works of Xiaoping Deng (Volume II) $\left(2^{\text {nd }}\right.$ ed, 1994) 168; Xiaoping Deng, Selected Works of Xiaoping Deng (Volume III) (in Chinese) (2nd $\mathrm{ed}, 1994) 285$. 
increased transparency. Indeed, the apparent fast tracking of formal FOI legislation at city, provincial and national level was conditional on the Chinese government having acquired confidence from various openness practices in the last three decades. These practices included openness in village and government affairs and local FOI rulemaking activities in particular (see Chapter 7). They, together with more proactive disclosure of crisis information (see 3.2.3) and administrative transparency appearing many administrative laws (see 5.2.4), gradually reduced the level of secrecy in the Chinese information environment, developing a favourable environment for FOI.

\subsubsection{A limited push model of FOI legislation}

China's FOI legislation focuses on proactive disclosure or 'push', rather than citizens-initiated access or 'pull' (see 8.1.2). ${ }^{82}$ The terms push and pull, supply and demand, proactive and reactive disclosure/access are used interchangeably in this thesis. ${ }^{83}$ The greater focus on proactive disclosure in China's FOI legislation, which regards information requests as a last or at least secondary resort, ${ }^{84}$ is a significant divergence from a traditional or classical version of FOI legislation. However, it should be noted that a push model of FOI legislation is emerging around the globe. A few countries, including the UK and Mexico, and several states in Australia, namely Queensland, Tasmania and New South Wales, are seeking to amend their FOI legislation by strengthening proactive disclosure (see 8.1.1).

82 The use of the term push and pull to differentiate models of FOI legislation comes from the work of Kubicek and Paterson. See Herbert Kubicek, 'Third-Generation Freedom of Information in the Context of E-Government: The Case of Bremen, Germany' in Georg Aichholzer and Herbert Burkert (eds), Public Sector Information in the Digital Age: Between Markets, Public Management and Citizens' Rights (2004) 275, 280; Moira Paterson, Freedom of Information and Privacy in Australia ( $1^{\text {st }} \mathrm{ed}$, 2005) 498. There is a common use of the terms pull and push in Australia, led by the FOI Independent Review Panel chaired by David Solomon. See The FOI Independent Review Panel, The Right to Information: Reviewing Queensland's Freedom of Information Act (2008). The discussion paper of Queensland's FOI legislation also agreed on the use of this term. See The FOI Independent Review Panel, Enhanced Open and Accountable Government: Review of the Freedom of Information Act 1992, Discussion Paper (2009).

83 The economic terms supply and demand developed by Marshall for market analysis are used here to help form a clear description of the situation of information flow from the government to the public (see 2.3). Supply and demand are two ways of information flow. The supply side refers to the government which controls and releases information, and the demand side refers to the public which receives information. See Alfred Marshall, Principles of Economics (first published 1890, $8^{\text {th }}$ ed, 1920) $323-503$.

84 See above $\mathrm{n} 82$ and the companying text. 
China's push model grew out of its local conditions, including two decades of limited proactive disclosure practices and an improved information environment due to the formation of multiple paths for information flow. Other local conditions, including a dense population, vast territory and high volume of government information, ${ }^{85}$ also contributed to the push model. However, the degree of China's push model of FOI legislation has been restricted by several factors, including a limited access mechanism, broad and vague exemptions and omission of the principle of maximum disclosure (see Chapter 8).

\subsection{Implementation: a revised compliance analysis model}

The current FOI compliance analysis model created and developed by Roberts, Snell, Darch and Underwood ${ }^{86}$ to explain the differential performance of government compliance with FOI legislation in a jurisdiction ${ }^{87}$ is restricted in its application to China. The model was developed largely on the experiences of FOI in advanced liberal democracies, such as Canada, Australia and New Zealand, and new democracies like South Africa. A mechanical use of the current compliance analysis to China produces a far too negative picture. Thus, without undermining the analytical integrity of the existing compliance model, the thesis suggests a modification of this model to provide a better explanatory framework for Chinese FOI, and to reveal the real strengths and weaknesses of China's FOI reform.

\subsubsection{Reflection on the current compliance analysis model}

The development of a compliance analysis model is 'an important step forward in a generally under-theorized field'. ${ }^{88}$ This model has been named the Roberts-Snell

\footnotetext{
85 Xueshan Yang, 'Subsidiary Report on Learning FOI Regulations' (Speech delivered at Conference on Learning FOI Regulations, Beijing, 19 May 2007).

86 Roberts, above n 30; Snell, above n 30; Darch and Underwood, above n 7, 119; Colin Darch and Peter Underwood, 'Freedom of Information Legislation, State Compliance and the Discourse of Knowledge: The South African Experience' (2005) 37 International Information and Library Review 77, 77-80.

87 Snell, above 46, 298.

88 Darch and Underwood, above n 86, 80.
} 
model ${ }^{89}$ However, this model remains in an early stage of development. It analyses compliance issues from reactive disclosure and in a static way. As discussed below, this model is also ineffective in comparing FOI performance across different jurisdictions. The current compliance analysis model can be improved through the incorporation of a push and pull focus inherent in an information flow perspective (see 1.3.3).

\section{The Roberts-Snell compliance analysis model}

A prototype of the compliance analysis model was first developed by Roberts in 1998 for analysing government non-compliance with FOI legislation in Canada. ${ }^{90}$ Snell developed this model between 1999 and 2001 by exploring government compliance and non-compliance with FOI legislation in Australia in terms of the types of information sought and information requestors. ${ }^{91}$ However, the factor of government capacity and willingness was only implied in the Roberts-Snell compliance analysis model. Delagrave added this factor to the Roberts-Snell model in order to examine the role of a culture of openness in ensuring compliance. ${ }^{92}$ Government and public capacity to ensure compliance was explicitly addressed by Roberts in $2005,{ }^{93}$ but government and public willingness was still implicitly addressed. Darch and Underwood revised the Roberts-Snell model by adding the variables of government capacity and willingness to different levels of government compliance and non-

Ibid. Darch and Underwood, above n 7, 119.

Roberts, above n 30. In 2002, Roberts developed government non-compliance or bureaucratic resistance and classified it into two categories: formal and informal ones. See Alasdair Roberts, 'New Strategies for Enforcement of the Access to Information Act' (2002) 27 Queen's Law Journal 647, 650-9; Alasdair Roberts, 'Dashed Expectations: Governmental Adaptation to Transparency Rules' in Christopher Hood and David Heald (eds), Transparency: The Key to Better Governance? (2006) 107, 109-17. Other scholars, such as Pasquier and Vileneuve, also established a typology to observe bureaucratic resistance to FOI legislation. See Martial Pasquier and Jean-Patrick Vileneuve, 'The Totally Transparent Administration: Radical Change or Bureaucratic Illusion?' (Paper presented at Conference on Public Managers under Pressure between Politics, Professionalism and Civil Society, Milan, 6 September 2006).

91 Rick Snell, 'Administrative Compliance and Freedom of Information in Three Jurisdictions: Australia, Canada and New Zealand' (Paper presented at Conference on Freedom of Information: One Year on, Dublin, 23 April 1999); Snell, above n 30.

92 Andrée Delagrave, Creating a Culture of Openness \& Transparency (2001) Access to Information Review Task Force <http://www.atirtf-geai.gc.ca/speeches/london01-e.html> at 18 August 2009.

93 Roberts, above n 30, 107-123. 
compliance (Table 1) ${ }^{94}$ They applied this revised model to analyse compliance issues in South Africa.

\section{Table 1 The Roberts-Snell compliance analysis model}

\begin{tabular}{||l|l|l||}
\hline Level & Continuum & Behaviours \\
\hline $\begin{array}{l}\text { Proactive } \\
\text { compliance }\end{array}$ & $\begin{array}{l}\text { High capacity } \\
\text { High willingness }\end{array}$ & $\begin{array}{l}\text { Information made available before requests; } \\
\text { exemptions waived; review perceived as } \\
\text { quality control. }\end{array}$ \\
\hline $\begin{array}{l}\text { Administrative } \\
\text { compliance }\end{array}$ & $\begin{array}{l}\text { Capacity } \\
\text { Willingness }\end{array}$ & $\begin{array}{l}\text { Co-operative attitudes; exemptions used } \\
\text { minimally; review seen as guide for future } \\
\text { decisions. }\end{array}$ \\
\hline $\begin{array}{l}\text { Administrative } \\
\text { non-compliance }\end{array}$ & $\begin{array}{l}\text { Low capacity } \\
\text { Willingness in doubt }\end{array}$ & $\begin{array}{l}\text { Inadequate resources; poor record keeping; } \\
\text { FOI accorded low priority. }\end{array}$ \\
\hline Adversarialism & $\begin{array}{l}\text { Capacity irrelevant } \\
\text { Unwillingness }\end{array}$ & $\begin{array}{l}\text { Us-and-them attitude; exemptions relied on; } \\
\text { delaying tactics; no explanations. }\end{array}$ \\
\hline $\begin{array}{l}\text { Malicious } \\
\text { non-compliance }\end{array}$ & $\begin{array}{l}\text { Capacity irrelevant } \\
\text { Malice }\end{array}$ & $\begin{array}{l}\text { Shredding; information not filed / kept; } \\
\text { documents removed from files. }\end{array}$ \\
\hline $\begin{array}{l}\text { Pre-emptive } \\
\text { destruction }\end{array}$ & Criminality & $\begin{array}{l}\text { Shredding; burning; expatriation of records; } \\
\text { documents removed from files. }\end{array}$ \\
\hline \hline
\end{tabular}

Source: Derived from Chapter 4 in Colin Darch and Peter Underwood, Freedom of Information and the Developing World: The Citizen, the State and Models of Openness ( $1^{\text {st }}$ ed, 2009) 119.

The Roberts-Snell compliance model assumes certain conditions for making FOI legislation operate in practice, which generally relate to both the capacity and willingness of the supply side/government and the demand side/the public. The following two points explain this. First, from the supply side, the compliance analysis literature requires certain capacity, including advanced democratic institutions, a well-developed rule of law, good record keeping practices, a professional civil service and adequate resources to comply with FOI legislation. ${ }^{95}$ However, the existing literature presupposes low willingness of the government to comply, because FOI legislation limits its power, and this encourages aggressive and often negative administration of FOI legislation. ${ }^{96}$ The enduring adversarial nature of FOI in

94 Darch and Underwood, above n 7, 119; Darch and Underwood, above n 86.

95 Roberts, above n 7, 107-16.

96 The information asymmetry theory developed by Nobel Prize winners like Stiglitz can be used to illustrate this agency problem. Stiglitz argues that 'even seemingly public-spirited public servants often engage in secrecy'. See Joseph Stiglitz, 'Transparency in Government' in the World Bank (ed), The Right to Tell: The Role of Mass Media in Economic Development (2002) 27, 34-5; Joseph Stiglitz, 'On Liberty, the Right to Know, and Public Discourse: The Role of Transparency 
countries, such as Australia, is a central feature of compliance with FOI legislation. Bureaucrats often regard many requesters as their opponents who want to discredit them. ${ }^{97}$

Second, while strong or even aggressive input from the demand side is needed to ensure compliance, this input requires users to have a strong sense of citizenship, capacity to use government information, a free press and independent NGOs. ${ }^{98}$ Strong capacity of players on the demand side only means that the possibility of applying for government information is high. Actual use of FOI legislation may not realise this high possibility. In addition to this capacity, the compliance analysis literature presumes strong willingness of demand side players to continue after a passionate and vigorous campaign for FOI reform. In reality, the willingness of the demand side drivers, especially the media, is constrained by many factors arising from their own issues, such as personal relationships, readership and unwillingness to undertake difficult tasks, ${ }^{99}$ and government non-compliance practices. ${ }^{100}$

in Public Life' (Speech delivered at Oxford Amnesty Lecture, Oxford, 27 January 1999). Sociological theories of bureaucracy developed by Weber, Marx and others can also be used to explain the negative administration of FOI. FOI scholars, such as Darch, Underwood and Terrill, have already pointed out this. See Darch and Underwood, above n 7, 91-8 and Terrill, above n 13, 60.

97 Missen, above n 14, 42; Stephen Brown, 'Freedom of Information' (Paper presented at Seminar on Freedom of Information - A Cultural Perspective, Canberra, 21 February 2000). The Australian Commonwealth Ombudsman found, for instance, that 'a number of agencies were displaying an apparent disregard of, or apathy toward, the provisions of the FOI Act'. The Commonwealth Ombudsman, Annual Report 1996-1997, 75.

98 Roberts, above $\mathrm{n} 7,116-22$.

99 Jack Herman, 'The Urgent Need for Reform of Freedom of Information in Australia' (Speech delivered at Conference on Public Right to Know, Sydney, 21 August 2004); Kavi Chongkittavorn, 'Thai Journalists and Access to Information' (Paper presented at Conference on Freedom of Information and Civil Society in Asia, Tokyo, 13-14 April 2001); Snell, above n 30, 198-9.

100 The practices include long processing time, high fees, wholesale redactions and sweeping exemptions. See Simon James, 'The Potential Benefits of Freedom of Information' in Richard Chapman and Michael Hunt (eds), Open Government in a Theoretical and Practical Context (2006) 27, 27-8; Martin Rosenbaum, 'Open to Question - Journalism and Freedom of Information' (2004) 9 Communications Law 126, 131; Lamble, above n 31. 


\section{Assessment of the Roberts-Snell compliance analysis model}

The Roberts-Snell compliance analysis model has weaknesses in analysing FOI performance in a broad, dynamic and cross-jurisdictional way, as explained in detail below. First, it only focuses on the pull/demand aspect of FOI, paying little attention to the push/supply aspect of FOI. A singular focus on the pull aspect of FOI does not help obtain a broad picture in an information environment. Second, the current model evinces a static rather than dynamic analytical framework. Information or information release, rather than information flow in an information environment, is its focus. It consequently lacks explanatory power for comparing FOI performance over time. This thesis does not undertake a long-run comparison of FOI performance in China, only examining it over six months (1 May 2008-31 October 2008) due to time and resource constraints. However, analysis of this brief period is valuable as it demonstrates that information flow in China has improved, especially the push aspect of FOI (see Chapter 9). Third, the current compliance analysis model lacks effectiveness in a dynamic comparison of the differentials of FOI performance across jurisdictions. ${ }^{101}$

Information flow analysis has the potential to enhance the current compliance analysis. It puts FOI into a wide information environment. This helps identify twodirectional nature of FOI - the push and pull aspects of information flow, and capture the dynamics of FOI or changes in these two aspects of FOI over time.

\subsubsection{Concerns about implementation of FOI legislation in China}

Concerns about the implementation of FOI legislation in China are related to the willingness and capability of both the supply and demand sides, as explained in detail below. First, the concern over compliance with FOI legislation in China generally arises from doubts about the Chinese government's willingness to subject itself to the normal demand side drivers of FOI, including journalists, lawyers, NGOs and

101 Snell, above n 46, 300. 
citizens seeking to hold government agencies to account. ${ }^{102}$ Further, there are concerns about China's capability to comply with its own legislation due to existing poor records management, ${ }^{103}$ insufficient resources ${ }^{104}$ and bureaucratic culture. ${ }^{105}$ The worry about poor records management is justified as chaotic records management cannot ensure the availability of information for access. ${ }^{106}$ In particular, the central government's capacity to force its subordinates to implement FOI legislation raises doubt over compliance with FOI legislation as ' $[\mathrm{t}]$ he policy applies across the largest bureaucratic complex on the planet'. ${ }^{107}$ In addition, the current literature, both Chinese and non-Chinese, highlights potential unwillingness of the Chinese government to enforce FOI legislation arising out of concerns over the diminution of the central government's impetus after the change of policy objectives $^{108}$ and the nature of China's bureaucracy. ${ }^{109}$

Second, a focus on the demand side raises concerns about the incentives for citizens to request government information, and their capacity to act on it (see 10.3.1). Roberts states that '[i]t remains to be seen how well this policy will work. ... The lack of a free press, limited political rights, and a weak judiciary also complicate matters. What good is information, after all, if you lack the capacity to act on it? ${ }^{110}$ There are concerns about citizens' lack of incentives to request government information, especially public information. Darch and Underwood doubt the concept of citizenship as a tool for asserting rights against the state in China, arguing that the

102 Snell argues that the type of requesters is a key determinant of government compliance. Aggressive use of FOI legislation by the demand side drivers, journalists in particular, can only lead to a high level of non-compliance. See Snell, above n 46, 298-9.

103 Hanhua Zhou, 'FOI Regulations Will Bring about Six Changes' (in Chinese) People's Daily (Beijing) 14 February 2007, 13; Suzanne Piotrowski et al, 'Key Issues for Implementation of the Chinese Open Government Information Regulations' (2009) 69 (Supplement 1) Public Administration Review 129, 131.

104 Roberts, above n 7, 113.

105 Darch and Underwood, above n 7, 173.

106 Peter Sebina, Freedom of Information and Records Management: A Learning Curve for Botswana (D Phil Thesis, University College London, 2006) 190; Rick Snell and Peter Sebina, 'Information Flows: The Real Art of Information Management and Freedom of Information' (2007) 35 Archives and Manuscripts 54, 73.

107 Roberts, above $\mathrm{n} 77$.

108 Zhou, above n 74.

109 Darch and Underwood, above n 7, 173.

110 Roberts, above n 77. 
state's relation to citizens is 'conceptualised in a way that leaves virtually no space' for claiming the access right. ${ }^{111}$ Furthermore, there are concerns about an apparent low use of FOI legislation by Chinese journalists, primarily due to government control of media (see 10.3.2). ${ }^{112}$ Some authors are, moreover, sceptical of the role of Chinese courts in compelling government compliance with access requests. ${ }^{113}$

\subsubsection{A revised compliance analysis model incorporating a push and pull focus}

A singular focus on the problems of reactive disclosure and effective enforcement in China would be misleading. This thesis thus utilises a revised compliance analysis model that focuses on the outcome of information flow resulting from a changed willingness and capability of players on both the supply and demand sides to examine compliance issues in China. The revised compliance analysis model incorporating a push and pull focus allows the application of a broad and long-run analysis. Chapters 9 and 10 apply this revised analytical model.

The current compliance analysis pays too little attention to the specifics of China's FOI reform, which is largely generated internally and focuses on the proactive disclosure duty of the government. The current compliance model is constructed on the basis that the FOI initiative rarely comes from the supply side, ${ }^{114}$ therefore possibly undermining its persuasive power in explaining China's FOI phenomenon. The internally generated nature of FOI reform suggests incentives for the Chinese government to enforce FOI legislation. Also, the current compliance model is based on FOI legislation where reactive disclosure features prominently, and so is at odds with China's FOI legislation, which places more emphasis on proactive than reactive disclosure.

Darch and Underwood, above n 7, 174.

112 Roberts, above n 7, 121; Rowan Callick, 'Chinese FOI Act Tied by Red Tape' The Australian (Sydney) 1 May 2008, 32.

113 Horsley, above n 3; Hubbard, above n 58, 11.

114 Blanton, above n 5, 7; Ackerman and Sandoval-Ballesteros, above n 10, 115. 
The changed willingness and capability of both the supply and demand sides have assisted in prompting government compliance with proactive disclosure in practice (see Chapter 9). In the last three decades there have been significant changes and trends that influence the Chinese government's willingness and capacity to comply with FOI legislation. A central political commitment and a number of transparency advocacy groups on the supply side have created willingness for other government agencies to become more transparent. Furthermore, the capacity of the government to implement FOI legislation has increased due to its changed technological, political, legal, economic and civil service conditions. Also, the demand side is not the same as it was three decades ago. Chinese citizens have improved their rights consciousness (see 10.3.1); media competition has increased and journalists enjoy greater freedom to publish (see 10.3.2); Chinese rights activists and lawyers are able and willing to request public information, becoming a major group of requesters to ensure government compliance (see 9.4); and Chinese review bodies, including administrative reconsideration agencies and courts, also aid in increasing the capacity of demand side players to redress government non-compliance with proactive disclosure requirements (see 9.3).

However, at this stage of implementation, there remain obstacles to compliance with reactive disclosure or the pull aspect of information flow in China. The Chinese government has typically responded with a controlling flow approach to information requests. Courts have bolstered this approach through various restrictions on FOI lawsuits, thus restricting the capacity of demand side players to request information flow from the supply side. And the use of FOI legislation by demand side players has been hamstrung by legal, political and resources constraints. The current problematic implementation of the access mechanism precludes any overly optimistic view about compliance with FOI legislation (see Chapter 10).

\subsection{The need for this research}

The research on China's FOI is necessary for at least two reasons. First, it affords a fuller understanding of the apparent paradox of the introduction of FOI legislation 
into China. The current analysis fails to provide a full and accurate account for this introduction (see 1.2). Some non-Chinese authors have grappled with the FOI phenomenon in China, but their explanations are limited. ${ }^{115}$ Roberts argues that the Chinese government recognised that FOI legislation might have helped improve control over a vast and unresponsive bureaucracy'. ${ }^{116}$ Another similar explanation is that FOI was endorsed by the Chinese central government to strengthen 'bureaucratic control'. ${ }^{117}$ This explanation cannot provide a more complete answer to the paradox of FOI legislation in China because it does not consider the influence and contribution of three decades of social, political, legal and economic reforms. Horsley's reference to 'economic and political motives' for FOI reform in China ${ }^{118}$ is accurate to a degree. ${ }^{119}$ However, a more extensive and systematic analysis of these motives is needed. Therefore, the existing literature should be supplemented and reconfigured to provide a more accurate analysis of the development of FOI in China.

Secondly, the concerns expressed, especially by non-Chinese observers, over the prospects of FOI implementation need to be addressed (see 1.3.2). The current compliance analysis, which focuses on reactive disclosure, is liable to misinterpret the actual dynamics of FOI reform in China. In part, it underplays the differences caused by a greater - if not almost exclusive - emphasis on proactive disclosure, and possibly overplays the weaknesses on the demand side. Further, it may overlook or attach too little significance to the slow but steady changes in social, political and legal reforms over the last three decades. Finally, the narrative about Chinese FOI, which is being generated by non-Chinese scholars, has shifted focus and study away from the internal or unique Chinese aspects of this reform process.

\footnotetext{
Roberts, above n 77; Horsley, above n 3; Hubbard, above n 58.

Roberts, above $n 7,110$.

Hubbard, above $\mathrm{n} 58,5$.

Horsley, above $\mathrm{n} 3$.

19 Jamie Horsley, China's Pioneering Foray into Open Government: A Tale of Two Cities (2003) Freedom of Information Organisation <http://www.freedominfo.org/news/20030714.htm $>$ at 23 August 2006; Jamie Horsley, Shanghai Advances the Cause of Open Government Information in China (2004) Freedom of Information Organisation <http://www.freedominfo.org/news/20040420. $\mathrm{htm}>$ at 23 August 2006; Jamie Horsley, 'Introduction on Open Government Information Implementation' (2006) 23 Government Information Quarterly 5-10; Horsley, above n 3.
} 


\subsection{Aims of research}

This research seeks to more thoroughly analyse the Chinese FOI phenomenon. Its specific aims are to:

1. Better understand the adoption of FOI legislation in China. This thesis examines the nature and extent of the driving forces behind FOI reform in China.

2. Better elucidate the legislative process of FOI in China. This research examines the process of gradual legislative reforms leading up to the introduction of FOI legislation in China.

3. Analyse a limited push model of FOI legislation in China.

4. More effectively assess the implementation of FOI legislation in China, and evaluate the strengths and weaknesses in the enforcement process.

\subsection{Methodology}

A critical examination of primary and secondary sources has been the main method used in this thesis. The documentary data was gathered from a variety of sources, which included publicly available policy documents, published news reports, journal articles, books, theses, conference papers, transcripts of speeches, relevant laws and regulations and so on. This method was conducted primarily via searching the Internet, accessing databases, and visiting libraries and archives, particularly in China.

The documentary data is analysed through a historical and comparative approach, as explained in detail below. First, analysis of changes over time is essential to gain broad and dynamic insights into China's FOI phenomenon. The review of historical literature reveals a trend toward government receptivity to FOI in China. FOI has received 'little historical treatment' ${ }^{120}$ A few scholars, such as Lamble and Terrill have applied historical analysis to FOI phenomena. ${ }^{121}$ The thesis provides another

120 Terrill, above n 37, 3; Lamble, above $n 31$.

121 Terrill, above n 37; Lamble, above $n 31$. 
example for the application of this analysis. Second, the application of the comparative approach is a response to the call of Snell, who urges more comparative studies in FOI. Snell observes that the comparison of FOI is 'relatively unexplored', ${ }^{122}$ thus calling for 'comparative studies in this area which include, but extend beyond, singular case studies or collections of case studies'. ${ }^{123}$ To respond to the call of 'cross-jurisdictional analysis' ${ }^{124}$ of FOI developments, this thesis attempts to better understand China's response to FOI through comparisons with other countries' FOI developments, and also presents a special FOI case for future comparative studies.

The second method is an extensive range of interviews conducted in China between June and August 2008 with Chinese participants in six provinces located in Central, East and North China, including government officials (central: 4; local: 5), archivists (6), librarians (6), academics (3) and ordinary citizens (12). Participants were selected based on their expertise or interest in FOI. The variety of localities, ranks and groups indicates that the empirical findings in this thesis are illustrative and representative.

The collection of interview data adhered to the following process according to Australian human research ethics requirements. Approval for the project was obtained from the Social Sciences Human Research Ethics Committee (Tasmania) Network (Ethics Reference Number: H9865). Sample interview questions were designed prior to the interviews. The interviews were accompanied by an information sheet and a consent form (Appendix 1 and 2). Most of the interviews were conducted on an individual basis. The interviews were undertaken personally or by phone dependent on factors such as time, availability and distance. Interview questions were distributed to all participants via a variety of methods, such as emails, telephone calls and in person. Extra questions were asked after direct communications with participants. The study was explained to them, and they all knew that their involvement in this study was voluntary. All participants required the assurance of

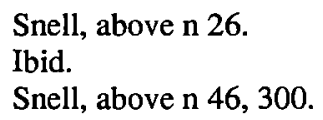


anonymity, and this research has maintained this requested level of confidentiality. The interviews were transcribed and returned to the participants for verification and modification when feasible.

The interviews provide an invaluable source of information on both demand and supply side players' view on many issues related to FOI. Interview data is analysed through a qualitative research approach to provide insights into the real situation of information flow in China, and verify some key arguments in the thesis. In particular, some parts of Chapters 9 and 10 rely on this collected data (see 9.1 and 10.3).

\subsection{Note on terminology}

Some terms need to be clarified. Openness in Government Affairs or OGA (Zhengwu Gongkai) means that government agencies proactively disclose information at their own discretion. ${ }^{125}$ OGA was practiced in China before implementation of FOI legislation. Freedom of information (Zhengfu Xinxi Gongkai) refers to proactive and reactive information disclosure. Two aspects of FOI, including push/proactive disclosure and pull/reactive disclosure are discussed in this thesis. China's FOI legislation, titled 'Zhengfu Xinxi Gongkai Tiaoli', in the thesis is translated as Freedom of Information Regulations, rather than Open Government Information Regulations which is generally used. One key reason for this translation is that the term Zhengfu Xinxi Gongkai was originally used to diminish the political sensitivity of FOI (see 6.1.3). ${ }^{126}$ Another reason is that the use of the phrase Open Government Information for China's FOI has already created the wrong impression that transparency reform in China focuses on discretionary disclosure without 'the

125 There is no general consensus about the coverage of Zhengwu Gongkai in China. The coverage has been explained to include all openness practices implemented by any state agency and party apparatus. However, sometimes, the coverage has been interpreted to only include government agencies. See Hongchao Lin, 'An Overview of FOI' in Yuchuan Mo and Hongchao Lin (eds), Interpretations of China's FOI Regulations (in Chinese) (2008) 27, 35-7. While the coverage could be understood diversely, there is a consensus that Zhengwu Gongkai is a non legallybinding proactive way of information disclosure.

126 Hanhua Zhou, 'The Legislative History of FOI Regulations in China' (in Chinese) (2008) $7 \mathrm{E}$ Government 15, 16. 
creation of enforceable legal obligations'. ${ }^{127}$ This is because 'open government information' has been used in a pejorative sense in the western world, the UK in particular. ${ }^{128}$ In fact, Chinese experts, such as Zhou, argue that the Chinese term Zhengfu Xinxi Gongkai has been used to strengthen the government's legally-binding disclosure duty ${ }^{129}$ without the pejorative connotations. This means that the term Freedom of Information Regulations or FOI Regulations should not be regarded as a misnomer for China's legislation.

Legislation in this thesis is an Act or law, regulation and rule.

\subsection{Chapter summaries}

Chapter 1 comprises this introduction.

Chapter 2 explores the capacity and effectiveness of information flow analysis as an analytical device to further advance the current understanding of FOI in relation to China, but also possibly for other jurisdictions, and to enable comparisons.

Chapter 3 examines the influence of the improved Chinese information environment on China's capacity to accept FOI. It compares different information management approaches to crises taken by the Chinese government over time, and argues that without the improvement of the information environment, the Chinese government would have been unlikely to be receptive to FOI reform.

127 Steve Wood, when discussing several articles on China's FOI development published by the Government Information Quarterly, states that 'China is perhaps not the first place that springs to mind when we think about FOI and Open Government, especially in general terms of freedom of expression and use of the Internet ... Though it has to be emphasised that Open Government and Freedom of Information legislation are two different things, the former is more focused upon proactive, discretionary release of information, the latter on a presumptive right to know and right of access to all public information (with some exemptions) enshrined in law'. See http://foia.blogspot.com/2006/06/open-government-in-china-china-is.html.

The reason for Wood holding this viewpoint is that the term Open Government or Openness, as noted by Birkinshaw, 'has been used in a pejorative sense in the UK to avoid legal obligations of access to information'. See Patrick Birkinshaw, 'Freedom of Information and Openness: Fundamental Human Rights' (2006) 58 Administrative Law Review 177, 190; David Heald, 'Varieties of Transparency' in Christopher Hood and David Heald (eds), Transparency: The Key to Better Governance? (2006) 25, 26; 'Freedom of Information Draft Bill', Public Administration Committee, HC 570, $3^{\text {rd }}$ Report Session 1998-99, HC 570-I, Para 28.

129 Zhou, above n 69, 15; Lin, above n 125, 58. 
Chapter 4 examines the influence of a long democratisation process on China's capacity to accept FOI. It argues that FOI reform in China was conditional on the dynamics of gradually upgrading openness practices associated with the democratisation reform agenda.

Chapter 5 explores the influence of administrative law reforms on China's capacity to accept FOI. It argues that three decades of administrative law reforms gradually ameliorated the Chinese information environment, resulting in an acceptance of the pull aspect of FOI in China.

Chapter 6 examines the roles of two main driving forces - economic growth and anti-corruption efforts - in influencing China's capacity to accept FOI. It argues that these two forces should be accorded an important but secondary role in FOI reform, as they only have a limited and indirect influence on relaxing the secretive Chinese information environment.

Chapter 7 explores the process of gradual legislative reforms leading up to the introduction of FOI legislation in China. It shows that the FOI Regulations were a key but interim result of many increments.

Chapter 8 examines China's FOI Regulations. It argues that China has adopted a push model of FOI legislation that emphasises proactive disclosure of government information.

Chapter 9 explores the strengths in the implementation of FOI legislation in China. It argues that the real strength of the way that FOI legislation is implemented in China is in compliance with proactive disclosure requirements.

Chapter 10 explores the weaknesses in the implementation of FOI legislation in China. It argues that while significant steps to government compliance with proactive disclosure requirements can be ensured, it is difficult to anticipate that reactive disclosure will operate effectively in China at this early stage of implementation.

Chapter 11 concludes the thesis. 


\section{2: INFORMATION FLOW AS AN}

\section{ANALYTICAL DEVICE FOR FOI RESEARCH}

\subsection{Introduction}

This chapter explores the capacity and effectiveness of information flow analysis as an analytical device to advance the current understanding of FOI in relation to China, but also possibly for other jurisdictions, and to enable comparisons. Information flow analysis is an analytical tool that can be used to explore the gradual development over time of government receptivity to FOI in the Chinese information environment. The primary objective of this chapter is to develop information flow analysis. This is a necessary first step in evolving a theory of information flow. The thesis argues, for China, improved information flow resulting from enhanced social, political, legal and economic conditions has decreased the level of information asymmetry in the Chinese information environment, thus increasing government receptivity to FOI.

This chapter has five sections. Section one explores the reasons for developing an analytical device in order to analyse FOI. Section two examines the foundation on which the analytical tool of information flow has been developed. Section three discusses the concept of information flow as an analytical device for theoretical and comparative analysis of FOI. Section four examines high utility of information flow as a tool for analysing and comparing FOI developments. The final section explores the limitations of the application of information flow analysis.

Information flow analysis presented in this thesis has been jointly developed with Rick Snell, Paul Hubbard and Rhys Stubbs. Their contributions are acknowledged. 


\subsection{The reasons for developing an analytical device for FOI research}

FOI is 'a generally under-theorized field'. ${ }^{1}$ Academic analysis of FOI needs to shift its focus from 'descriptive case studies' ${ }^{2}$ to 'comparative or theoretical analysis' better explain the divergence of FOI developments around the world. This involves three elements.

First, academic analysis of FOI is still in a very early stage of theoretical development. ${ }^{4}$ Darch and Underwood's critique places FOI theoretical development more at the concept, rather than the mini-theory stage. ${ }^{5}$ The rapid spread of FOI in the last decade to a diverse range of countries and political systems has outpaced the development of a critical literature and analysis to fully explain this phenomenon. FOI analysis is struggling as more and more exceptions to the general explanatory models (see 1.1) appear. The divergence is not just at the development stage, but extends to the implementation phase. A better understanding of the divergence of FOI developments around the world necessitates the utilisation of a new explanatory model.

Furthermore, China's FOI phenomenon has caused the distance between theoretical understanding and the divergence of FOI developments to become much greater than before. It is said that "the "rhetoric of transparency" ... has been spreading as far as

1 Colin Darch and Peter Underwood, 'Freedom of Information Legislation, State Compliance and the Discourse of Knowledge: The South African Experience' (2005) 37 International Information and Library Review 77, 80.

2 Darch and Underwood argue that the existing FOI literature is 'largely ... descriptive case studies' and 'relatively little in the way of comparative or theoretical analysis'. See Colin Darch and Peter Underwood, Freedom of Information and the Developing World: The Citizen, the State and Models of Openness ( $\left.1^{\text {st }} \mathrm{ed}, 2009\right) 50$.

3 Darch and Underwood, above n 2; Rick Snell, 'Using Comparative Studies to Improve Freedom of Information Analysis: Insights from Australia, Canada and New Zealand' (Paper presented at Sixth National and Second International Congress on the Right to Information, Mexico, 8-11 November 2005).

4 Van de Donk and Snellen classify theory development into four key phases: concepts as mini theories, statements as prototheories, empirical generalisations as embryonic theories and more or less mature theories. See Wim B.H.J.van de Donk and Ignace Th.M. Snellen, 'Towards a Theory of Public Administration in an Information Age?' in I.Th.M. Snellen and W.B.H.J.van de Donk (eds), Public Administration in an Information Age: A Handbook (1998) 3, 3-8.

5 Darch and Underwood, above $\mathbf{n} 1$. 
China in the past few decades ${ }^{6}{ }^{6}$ There is a need to add more intellectual rigour, understanding and analysis to accounts of China's FOI phenomenon. The current explanations, including economic growth, globalisation and the fight against corruption, cannot fully account for this phenomenon because other social, political and legal rationales have not been taken into account. A new analytical device may bridge the gap in understanding the wide and rapid diffusion of FOI around the globe.

Second, a more effective analytical device is needed for comparative analysis of FOI, which remains at an early stage of development (see 1.6). The current Roberts-Snell compliance analysis model (see 1.3.1) is a useful tool for comparing FOI performance, but it has limitations particularly with regard to comparisons of FOI performance between very different systems, ${ }^{7}$ like those of Australia and China, and within jurisdictions over time.

Third, a broad and dynamic approach is essential to building better understanding of China's FOI phenomenon. Understanding of China's FOI is 'not a simple matter' comparing its FOI legislation with model FOI laws. It should be understood in a broad way and within a multifaceted context related to the changed social, political, legal and economic conditions. It also needs to be viewed from a historical or dynamic perspective. Observing and analysing changes over time is fundamental to understanding the genesis of the current push version of FOI legislation (see Chapter 8). The future of FOI reform cannot be fully realised without a sense of how local conditions have altered over time. North argues that ' $[\mathrm{h}]$ istory matters ... . Today's and tomorrow's choices are shaped by the past'. ${ }^{9}$ Lenin argued in 1919 that:

The most reliable thing in a question of social science ... is not to forget the underlying historical connection, to examine every question from the standpoint

6 Jeremy Lewis, FOIA Blog: Freedom of Information Laws and Policies (2009) Huntingdon College <http://ww 1.huntingdon.edu/jlewis/FOIA/FOIAlog.htm $>$ at 19 August 2009.

7 Rick Snell, 'Freedom of Information Practices' (2006) 13 Agenda 291, 300.

8 Paul Hubbard, 'China's Regulations on Open Government Information: Challenges of Nationwide Policy Implementation' (2008) 1 Open Government: A Journal on Freedom of Information $<$ http://www.opengov journal.org/article/viewArticle/2651> at 22 July 2009.

9 Douglass North, Institutions, Institutional Change and Economic Performance (1 $\left.{ }^{\text {st }} \mathrm{ed}, 1990\right)$ vii. North received the Nobel memorial prize in 1993. 
of how the given phenomenon arose in history and what were the principal stages in its development, and, from the standpoint of its development, to examine what it has become today. ${ }^{10}$

\subsection{The basis for developing information flow analysis}

This thesis argues that information flow analysis has the potential to improve the current theoretical and comparative analysis of FOI. Its potential can be demonstrated by its application to an explanation of China's FOI. Information flow analysis builds on a diverse range of literature, especially that concerning law, public administration and economics. Information asymmetry - a term used by economists, such as Stiglitz, Akerlof and Spence, who shared the 2001 Nobel memorial prize for their analyses of markets with asymmetric information ${ }^{11}$ - has been applied to FOI by some scholars. ${ }^{12}$ This application has provided an important part of the foundation for information flow analysis.

\subsubsection{FOI and information asymmetry}

Information flow analysis follows on from the efforts of various scholars who have been searching for ways to better analyse and explain all aspects of FOI including adoption, implementation and performance. The Roberts-Snell compliance analysis model is an important step in this process. In particular, it has assisted the thesis in paying attention to the roles of both government and public capacity and willingness in influencing FOI performance. However, Snell recognises the shortcomings of the

$10 \quad$ Vladimir Lenin, Lenin Collected Works (Volume 29) $\left(1^{\text {st }} \mathrm{ed}, 1961\right) 473$.

11 See http://nobelprize.org/nobel prizes/economics/laureates/2001/. Stiglitz applied the theory of information asymmetry to FOI. See Joseph Stiglitz, 'Transparency in Government' in the World Bank (ed), The Right to Tell: The Role of Mass Media in Economic Development (2002) 27, 27 44; Joseph Stiglitz, 'On Liberty, the Right to Know, and Public Discourse: The Role of Transparency in Public Life' (Speech delivered at Oxford Amnesty Lecture, Oxford, 27 January 1999).

12 Such as Snell, Sebina and Hubbard. Rick Snell and Peter Sebina, 'Information Flows: The Real Art of Information Management and Freedom of Information' (2007) 35 Archives and Manuscripts 54, 62-8; Snell, above n 7, 300-303; Paul Hubbard, 'Accountability in the Grey Area: Employing Stiglitz to Tackle Compliance in a World of Structural Pluralism: A Comparative Study' (2004) 111 Freedom of Information Review 26-32; Paul Hubbard, 'Freedom of Information and Security Intelligence: An Economic Analysis in an Australian Context' (2005) 1 Open Government: A Journal on Freedom of Information <http://www.opengovjournal.org/article/view Article/334> at 21 May 2009. 
current compliance analysis model, such as its singular focus on FOI legislation itself, and static analysis or comparison of compliance issues within jurisdictions (see 1.3.1). His work in 2006 went some distance toward overcoming the limitations of the current compliance analysis model. ${ }^{13} \mathrm{He}$ developed a simplified model of information asymmetry to compare the differentials in FOI performance between Australia and New Zealand over time. ${ }^{14}$

The application of the theory of information asymmetry to FOI has led to the idea of information flow analysis. First, the concept of information asymmetry provides a benchmark to compare changes in the level of information asymmetry in a particular jurisdiction over time. ${ }^{15}$ It can also be used as an effective measure to capture the different levels of information asymmetry across jurisdictions. ${ }^{16}$ However, the current comparison from an information asymmetry perspective is largely descriptive. It has less power to explain the reasons for the different levels of information asymmetry. An analytical tool, like information flow analysis, which focuses on information relationships in an information environment, can improve this explanatory capacity. Improved information flow between government and citizens resulting from social, political, legal and economic factors can shift a system from a closed or highly asymmetrical information environment to an open or less asymmetrical one in the long run. ${ }^{17}$

Second, the link between the development of FOI and a broad information environment has been explicitly or implicitly addressed in existing scholarly work. ${ }^{18}$ This has contributed to this thesis by recognising that an analysis of an information environment is relevant to an understanding of FOI reform. ${ }^{19}$ The concept of an

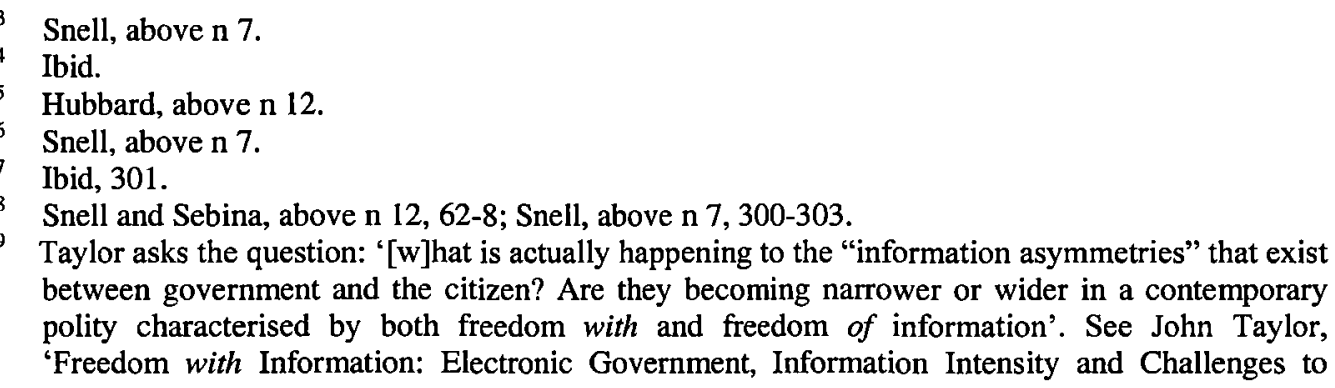

Taylor asks the question: "[w]hat is actually happening to the "information asymmetries" that exist between government and the citizen? Are they becoming narrower or wider in a contemporary polity characterised by both freedom with and freedom of information'. See John Taylor, 'Freedom with Information: Electronic Government, Information Intensity and Challenges to 
information environment has promising analytical potential for FOI scholars. This concept has shifted FOI analysis from a narrow and technical focus on the process of FOI requests to a wider multidimensional inquiry into the dynamics of information relationships and information flows between citizens and government. However, this potential has not been fully exploited.

\subsubsection{FOI and information flow}

The linkage between FOI and concepts, such as information asymmetry and information flow, has been shifted to a higher level by public administration scholars, especially Taylor. ${ }^{20}$ Taylor observes that information flow in a political system has been largely ignored by schools of public administration. ${ }^{21} \mathrm{He}$ has repeatedly called for more research on information flow or 'information relationships' 22 in an information environment or 'information polity' which refers to 'a political system made comprehensible by the information that flows, or fails to flow ${ }^{23}$ in and around government. Taylor has limited his information flow analysis to new questions in relation to public administration. ${ }^{24}$ However, this analysis has the potential to encourage an understanding of questions related to other research areas, including

Citizenship' in Richard Chapman and Michael Hunt (eds), Open Government in a Theoretical and Practical Context (2006) 125, 136.

20 John Taylor, 'Rediscovering the Grand Narratives of the Information Polity: Reflections on the Achievement and Potential of the EGPA Study Group on ICT in Public Administration' (2007) 12 Information Polity 213, 216; John Taylor, 'Informatisation as X-ray: What Is Public Administration for the Information Age?' in I.Th.M. Snellen and W.B.H.J.van de Donk (eds), Public Admintstration in an Information Age: A Handbook (1998) 21, 31.

21 See Taylors' articles cited in above $\mathrm{n} 20$.

22 Taylor in his Informatisation as X-ray article defines various sets of information relationships in the information polity, such as internal relationship in the machinery of government, consumer relationships and citizens relationships. Taylor, above $n$ 20, 27-28.

23 John Taylor, 'Governance and Electronic Innovation: Whither the Information Polity?' (1998) 1 Information Communication \& Society 144, 159; Taylor, above n 20. Taylor defines the term information polity in the following two articles. See John Taylor, 'Freedom with Information: Electronic Government, Information Intensity and Challenges to Citizenship' in Richard Chapman and Michael Hunt (eds), Open Government in a Theoretical and Practical Context (2006) 125, 136; John Taylor, 'The Information Polity' in William Dutton (ed), Society on the Line: Information Politics in the Digital Age (1999) 197, 198.

24 Taylor argues that ' $[t]$ he information polity encourages $x$-ray understanding of the body politic ..., enabling new evidence to be examined with new research questions, questions developed from theories and concepts utilized by orthodox studies of public administration'. See Taylor, above n $19,136$. 
FOI. In particular, Taylor's focus on information relationships encapsulates a key, although often implicit, focus of FOI analysis, namely the political and power dimensions of who can access government information and under what conditions. Taylor's analysis meshes with Roberts' concerns over who actually benefits from that access. $^{25}$

Information flow has not been considered a key factor in FOI reform in much of the FOI literature. Exceptions include the work of Roberts and Snell, which has been incorporated into a series of influential government reports, ${ }^{26}$ all of which have focused to one degree or another on concerns about flow of information in the information age. ${ }^{27}$ The absence of information flow from FOI discourse is not surprising as the common usage of the concept of an information age from the late 1980s took place after the development of most of the key features of the dominant FOI analysis. Accountability deficit has sufficed to explain the wave of adoption of

25 Alasdair Roberts, Blacked out: Government Secrecy in the Information Age ( ${ }^{\text {st }}$ ed, 2006) 116-20; Bookman and Guerrero Amparan ask that '[f]rom which government entities are individuals requesting information? Who, exactly, is requesting information? How do people, physically, make requests? These issues are treated serially, with a final section devoted to the successes Mexico can boast of so far, and more importantly, to outstanding challenges to continued implementation'. Zachary Bookman and Juan-Pablo Guerrero Amparan, 'Two Steps forward, One Step Back: Assessing the Implementation of Mexico's Freedom of Information Act' (2009) 1 Mexican Law Review 3, 32-49.

26 In particular, their work has been incorporated into government reports in Australia and Canada. See The FOI Independent Review Panel, The Right to Information Reviewing Queensland's Freedom of Information Act (2008); The FOI Independent Review Panel, Enhanced Open and Accountable Government: Review of the Freedom of Information Act 1992, Discussion Paper (2009); Tasmanian Department of Justice, Strengthening Trust in Government ... Everyone's Right to Know Directions Paper (2009) 33-38; The Access to Information Review Task Force, Access to Information: Making It Work for Canadians (2002) <http://www.atirtf-geai.gc.ca/access Report-e.pdf $>$ at 28 August 2009.

27 Roberts postulates that substantial changes in information and communication technologies to produce and distribute information require new responses and ways of envisaging and managing a more extensive 'pool of digitized "unstructured data" held by government agencies'. See Roberts, above $\mathrm{n} 25,200$. In a series of articles and presentations, Snell has followed up several themes and ideas outlined in Roberts' book and contrasted different information environments. See Rick Snell, 'Failing the Information Game' (2007) 10 Public Administration Today 5, 5-9; Rick Snell, 'Opening up the Mindset Is Key to Change' (2008) The Canberra Times 4 November 2008, 10, 11; Rick Snell, 'Releasing the Potential of FOI - Making the Transition from FOI Version 1.0 to FOI Version 2.0' (Speech delivered at the University of Tasmania Law School Staff Seminar, Hobart, 5 November 2008). In Canada and Australia, particularly in the latter, a number of government reports have focused on treating FOI as part of the whole of government information policy, thus approaching information access by addressing capacity on both the supply and demand sides (see 8.1.1). 
FOI legislation between the 1960s and the 1980s (see 1.1.1). However, the degree and type of information flow in a polity is a key factor that can influence government receptivity to FOI in an information environment (see 2.3).

\subsection{Information flow analysis}

Information flow analysis can assist a better understanding and explanation of the changing capacity over time of the Chinese information environment to accommodate FOI as an important policy instrument of government. This analysis indicates that information flow in terms of its patterns and conditions could be a useful focus for FOI research. This contrasts with most FOI literature, in which the concept of information tends to be used in a relatively static and physical way. ${ }^{28}$ Information flow, including flow of information from the government to citizens and from citizens to government, and flow among governments and among citizens, is crucial to an information environment. ${ }^{29}$ There are four streams of information flows in an information environment (Figure 1).

- Information flow within the supply side/government.

- Information flow within the demand side/the public.

- Push/supply/proactive disclosure: the supply side proactively discloses information to the demand side.

- Pull/demand/reactive disclosure: the demand side requests information from the supply side.

28 Snell has contrasted this static and physical conception of information to a more dynamic and multifaceted conception based around digital versions of information. See Snell's articles cited in above $\mathrm{n} 27$.

29 The direction of transparency was inspired by Heald's work. Heald classifies directions of transparency into vertical and horizontal transparency. See David Heald, "Varieties of Transparency' in Christopher Hood and David Heald (eds), Transparency: The Key to Better Governance? (2006) 25, 27. 


\section{Figure 1 Information flow in an information environment}

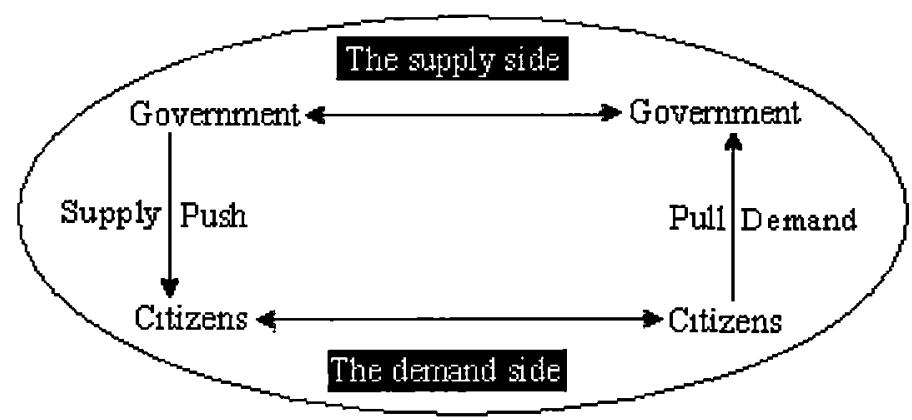

These four streams of information flow are correlative. The closure or liberalisation of one stream of information flow has an impact on others. This involves three elements. First, the liberalisation of information flow within the government or society can pave the way for new or renewed information flow between government and society (see 3.2). Second, the acceptance of the push aspect of information flow can help create an enabling environment for the acceptance of the pull aspect of information flow, and vice versa (see 4.2 and 5.2). Third, the acceptance of the pull aspect may facilitate information flow within public administration, as government is under pressure to shift the current static and government-oriented information management approach to more dynamic and user-oriented one. ${ }^{30}$

Information flow analysis can incorporate a supply and demand variable. The government represents the supply side, and the public or a citizen represents the demand side. Whilst the terms supply and demand have been commonly used by Marshall and other economists for market analysis, ${ }^{31}$ they have begun appearing in FOI forums and literature. ${ }^{32}$ It should be recognised that either government or

30 FOI scholars, such as Sebina and Snell, have noticed the causal relationship between FOI and records management. See Peter Sebina, Freedom of Information and Records Management: A Learning Curve for Botswana (D Phil Thesis, University College London, 2006); Snell and Sebina, above n 12, 54-81.

31 Alfred Marshall, Principles of Economics (first published $1890,8^{\text {th }}$ ed, 1920) 323-503.

32 The Hon. Sir Mason. Anthony, 'The Relationship between Freedom of Expression and Freedom of Information' in Jack Beatson \& Yvonne Cripps (eds), Freedom of Expression and Freedom of Information (2000) 225, 240; Laura Neuman and Richard Calland, 'Making the Law Work: The Challenges of Implementation' in Ann Florini (ed), The Right to Know: Transparency for an Open World (2007) 179, 181. 
citizens can play both roles of supplying and demanding information in a specific situation. However, the analysis in this thesis follows a general assumption that government supplies information, and citizens demand information. Arguably, the willingness and capability of the supply and demand sides are two factors that determine the effectiveness of information flow in an information environment. The use of these economic terms helps differentiate the capacity of key players, the government and the public, in an information environment. It focuses discussion on the government's capacity in terms of records management and civil service, and on the capacity of information receivers to use, distribute and analyse the information received. The use of these economic terms also assists in differentiating the roles of various government players who are willing to supply or prompt other agencies to supply information, and the roles of non-government players who are inclined to demand and utilise information (see Chapters 9 and 10).

The level of information asymmetry or secrecy which features in an information environment can be identified by examining information flow resulting from the shifting dynamics of social, political, legal and economic conditions. A particular jurisdiction may at one stage have an information environment marked by a high level of information asymmetry resulting from one stream of information flow. This environment indicates that supply and demand side players have low willingness and capacity to share information, thus presenting little opportunity for increasing government receptivity to FOI (see 3.1). At a later stage, the state may have an information environment characterised by a decreasing level of information asymmetry arising from multi streams of information flow. In such an ameliorated information environment, both supply and demand side players have increased their willingness and capability to share information, thereby making FOI first a beneficiary of, and then a contributor to the transformation of an information environment. China serves as a case in point (see 3.3 and 9.2). 


\subsection{High utility of information flow analysis}

An approach to FOI using information flow analysis offers an explanatory device for systematically understanding the development, implementation and future prospects of FOI (see 2.4.1). It may also improve existing compliance analysis, and have comparative utility to track FOI developments over time (see 2.4.2).

\subsubsection{An effective tool for explaining the divergence of FOI developments}

Information flow is a useful analytical tool for explaining the divergence of FOI developments, as illustrated in the following way. First, it is able to capture the change of government receptivity to FOI in a state. In a secretive or highly asymmetrical information environment, where the degree of information flow is low, the capacity to accept FOI is weak (see 3.1), especially for FOI reform dominated by supply side players. Whilst strong pressure from the demand side made it possible for the adoption of FOI between the 1960s and the 1980s, the effectiveness of FOI legislation was constrained due to a hostile attitude held by the supply side (see 1.1.1). However, in an enhanced information environment, where information flow has become a matter of routine, or information relationships have become important to the state, the compatibility of FOI with the environment is improved and the adversarial nature of FOI is lessened. Most of the current literature identifies FOI as a largely independent policy initiative, and thus omits a multifaceted analysis of the dynamic transformation of one jurisdiction's information environment.

Second, information flow analysis offers a useful analytical framework and a tool for comparisons of FOI legislation in a macro way (see Chapter 8). The current comparisons of FOI laws are largely undertaken in a micro way, focusing on the differences in detailed or black-letter clauses related to scope, time limits, exemptions and external review mechanisms. Information flow analysis provides a tool for comparing FOI laws from a macro perspective. Such a macro perspective assists in identifying two models of FOI legislation: push and pull, or 'version 1.0' and 
'version 2.0 '. ${ }^{33}$

Information flow analysis helps reposition the importance of access requests in improving information flow in a wide information environment. It has been gradually acknowledged that access requests should be accorded a less important role in FOI legislation, and the role of proactive disclosure in contributing to information flow should increase. ${ }^{34}$ As a result, a push model of FOI legislation has begun to be favoured around the world (see Chapter 8).

Third, information flow analysis may improve the application of the Roberts-Snell compliance analysis model to compliance analysis in China (see 1.3.3). The current compliance analysis model can be improved by combining a push and pull focus to better understand compliance issues in China (see Chapters 9 and 10). While information flow is treated at this stage as a subcomponent of the Roberts-Snell compliance analysis model, information flow analysis has the potential to become an independent framework for FOI analysis in the future, as it can help examine compliance issues in a broad and dynamic way.

The Chinese case indicates that information flow could be a useful measure of the effectiveness of FOI legislation in a jurisdiction. If FOI legislation has no, or a limited role in improving information flow, it is pointless or at least flawed. From this point of view, international non-government organisations, such as Article 19, may have oversold their model of FOI legislation, ${ }^{35}$ largely neglecting the building of an FOI newcomer's capacity to implement FOI legislation. ${ }^{36}$ Furthermore, information

33 FOI experts like Snell use 'version 1.0' and 'version 2.0' to describe the pull and push models respectively. See above $\mathrm{n} 27$ and the accompanying text about Snell's articles.

34 The Tasmanian Directions Paper classifies information disclosure into four levels or types: required, routine, active and assessed disclosure. Assessed disclosure is a type of information disclosure which is used to respond to access requests, and should be considered as a last resort. See Tasmanian Department of Justice, above n 26, 33-38.

35 Article 19, Right to Know: Principles on Freedom of Information Legislation (1999) <http://www.article19.org/pdfs/standards/righttoknow.pdf> at 1 July 2007; Article 19, A Model Freedom of Information Law (2001) <http://www.article19.org/pdfs/standards/modelfoilaw.pdf> at 18 August 2007.

36 This contrasts with the approach taken by the United Nations Educational Scientific and Cultural Organisation, which also aids nations to develop 'effective "infostructures", including information standards and management tools', to facilitate implementation of FOI legislation. The United 
flow analysis suggests that generally an administrative approach to implementation of FOI legislation is superior to a legalistic approach ${ }^{37}$ in contributing to information flow in an information environment. Greater willingness of the government to share information with the public can be found in the administrative, rather than legalistic approach.

Information flow analysis will be more effective if objective measurements can be developed and consistently apply across jurisdictions. Some organisations, such as Organisation for Economic Co-operation and Development and the Carter Centre, are developing detailed elements or indicators to measure implementation of FOI laws. ${ }^{38}$ Their work in progress can be improved if they utilise information flow as a key tool for developing these indicators.

\subsubsection{An effective measure for comparative studies of FOI}

Information flow analysis can contribute to the development of comparative FOI studies. It has great flexibility to interpret what information flow occurs within a particular time period, and to capture the direction and type of information flow change over time, thus helping improve the current largely descriptive and

Nations Educational Scientific and Cultural Organisation announces that it help other states 'create an enabling environment ... to achieve universal access to information and knowledge'. See http://portal.unesco.org/ci/en/ev.php-URL ID=19488\&URL DO=DO TOPIC\&URL SECTI $\mathrm{ON}=201 . \mathrm{html}$.

37 A legalistic approach heavily relies on legal professionals as major advocates and on formal appeal processes to solve disputes, but an administrative approach does not. Guidelines, mediation, negotiation and personal communication may be used to solve a systematic problem or individual disputes. Snell in his comparative administrative law lecture discusses these two different approaches to implementing FOI. He considers that Mexico, New Zealand and Sweden have adopted an administrative approach, but the US has adopted a much more legalistic approach. Australia and the UK have adopted a hybrid of administrative and legalistic approaches. See Rick Snell, 'Constructing a Field: Commonwealth FOI Studies' (Speech delivered at Comparative Administrative Law Lecture, Hobart, 7 August 2009). Other scholars, like Clark hold a similar view. See David Clark, 'Open Government in Britain: Discourse and Practice' (1996) 16 Public Money \&Management 23, 23.

38 The non-government organisation, Involve, produced a paper, titled 'Open Government: Beyond Static Measures' for Organisation for Economic Co-operation and Development in July 2009. Email from Karin Gavelin to Rick Snell, 19 August 2009; The Carter Centre developed a concept note, titled 'Access to Information Implementation Assessment Tool' in August 2009 to lay stress on the government inputs to measure implementation of FOI legislation. Email from Laura Neuman to Rick Snell, 19 August 2009. 
chronological comparative studies of FOI. ${ }^{39}$ For liberal democracies, such as Australia and Germany (see 6.2.2), the affordability of the expensive access mechanism or pull aspect of FOI became a major concern. FOI reform in Germany suggests that accountability deficit was not a sufficient condition for FOI reform. It postponed the adoption of FOI law until 2005. ${ }^{40}$ Bennett therefore argues that accountability deficit is only a necessary condition for FOI reform in advanced democracies. ${ }^{41}$ A key reason for this significant delay may have been the long duration of a highly asymmetrical and pre-Internet information environment, which resulted in high costs associated with access to information. ${ }^{42}$ These costs can only be reduced in an improved information environment by shifting the focus from the pull aspect to the push aspect of FOI.

Furthermore, information flow analysis can aid cross-jurisdictional comparisons by comparing the different development paths of FOI among jurisdictions. Information flow analysis helps identify two aspects of FOI: push and pull. The development path in China follows the path of push to pull (see Chapters 3, 4 and 5). The push aspect of FOI, which is the major discourse in China, is a less problematic approach for China than the pull aspect. The gradual transformation of the Chinese information environment has provided a receptive space for the push aspect, but the pull aspect was muted or not acceptable until the adoption of FOI Regulations.

In contrast, most FOI adopters, such as the US and Australia, follow a path of pull to push (see 8.1.1). The pull to push path is appropriate for a reform agenda vigorously driven by demand side players. However, the push to pull path suits the FOI initiative from the government, through gradually developing an enabling environment for FOI reform. Both the paths of pull to push and push to pull have the object of improving

39 For example, Toby Mendel, 'Freedom of information: A Comparative Legal Survey' ( $2^{\text {nd }}$ ed, 2008).

40 German adopted its FOI legislation on 8 July 2005 and brought it into effect on 1 January 2006.

41 Colin Bennett, Globalisation and Access to Information Regimes (2001) Access to Information Review Task Force <http://www.atirtf-geai.gc.ca/paper-globalisationl-e.html $>$ at 30 January 2008.

42 See Herbert Kubicek, 'Third-Generation Freedom of Information in the Context of EGovernment: The Case of Bremen, Germany' in Georg Aichholzer and Herbert Burkert (eds), Public Sector Information in the Digital Age. Between Markets, Public Management and Citizens' Rights (2004) 275, 275. 
information flow in an information environment.

This section indicates that information flow analysis is different from top-down or bottom-up analysis which focuses on the direction of FOI reform. Information flow analysis is capable of explaining FOI development over time, but neither top-down nor bottom-up analysis has this capability. Furthermore, information flow analysis does not singularly focus on FOI legislation itself. It can be used to analyse either top-down or bottom-up direction of FOI reform. Arguably, the key to understand any type of FOI reform is the lessening of difficulties with government receptivity to reactive disclosure through improving other relatively easier accepted streams of information flow.

\subsection{Limitations of the application of information flow analysis}

Whilst information flow analysis has great potential to facilitate a move away from largely 'descriptive case studies', ${ }^{43}$ and to improve current theoretical and comparative analysis of FOI, its use remains tentative. There are at least three reasons for this. First, terminology borrowed from different disciplines to build the analytical framework of information flow may be criticised as ad hoc and lacking in organic cohesion. Indeed, the reasons for selecting and matching these components or modules are linked to the availability of certain literature.

Second, information flow analysis is limited by the conceptual uncertainty around FOI. FOI is used interchangeably in the literature with other terms, including transparency, open government, openness, access to information and freedom of expression. ${ }^{44}$ The differences and meanings of these terms have lacked 'serious debate ${ }^{45}$ Information flow analysis calls on scholars to view FOI as a particular

\footnotetext{
43 Darch and Underwood, above $\mathrm{n}$ 1.

44 Michael Hunt and Richard Chapman, 'Open Government and Freedom of Information' in Richard Chapman and Michael Hunt (eds), Open Government in a Theoretical and Practical Context (2006) 1, 1; Patrick Birkinshaw, 'Freedom of Information and Openness: Fundamental Human Rights' (2006) 58 Administrative Law Review 177, 188-90; David Heald, 'Varieties of Transparency' in Christopher Hood and David Heald (eds), Transparency: The Key to Better Governance? (2006) 25, 25-6; Bookman and Guerrero Amparan, above n 25, 20-2.

45 Hunt and Chapman, above $\mathrm{n} 44$.
} 
form of information-flow, and to start addressing and assessing the exact relationship between loosely related terminology, in order to confront the conceptual uncertainties of FOI. To date, most of the analysis about FOI is cast in static, rather than dynamic terms; it must enter new conceptual territory.

Third, while information flow analysis allows more focus on information relationships in an information environment, this thesis mainly focuses on FOI, rather than other positive and negative information management regimes linked with FOI, such as archives, internet censorship, government secrecy, spin doctors, privacy, whistle blowing and public access to private sector information. All these information management regimes can be subsets or modules of a wider academic discipline information law, which could examine information relationships or information flows between different players in an information environment.

\subsection{Conclusion}

This chapter presents information flow analysis as a means of better understanding and explaining the changing capacity of the Chinese information environment to accommodate FOI. It argues that information flow in an information environment is a useful analytical device for better understanding FOI reform in China. Closer examination finds that FOI was first a beneficiary of the transformation of the Chinese information environment, but that it is now moving toward being a contributor to this transformation. The rest of the thesis applies information flow analysis to examine the origins of the adoption of FOI legislation in China and the prospects for its implementation.

The analytical tool of information flow is a dynamic and systematic explanatory framework for future FOI theoretical and comparative analysis. It may have wider applicability, as demonstrated by some parts of the thesis (See 5.1.1 and 8.1.1). FOI scholars should focus more on FOI from an information flow perspective, in order to examine the acceptance of FOI in an information environment and the role of FOI in contributing to the environment. 


\section{3: THE IMPROVED INFORMATION ENVIRONMENT AS A RATIONALE FOR FOI REFORM IN CHINA}

\subsection{Introduction}

This chapter examines the influence of the improved Chinese information environment on China's capacity to accept FOI. It utilises information flow in a crisis as a key lens through which to demonstrate the changing capacity of the Chinese information environment to accommodate FOI. The reasons for choosing this are the following. Any change in crisis information management makes a significant difference to the social order. Crises are also generally considered, albeit wrongly held, as a direct motive for FOI reform in China (see 3.2.3). This chapter compares different information management approaches taken by the Chinese government over time. It argues that without the improvement of the Chinese information environment due to the formation of multiple paths for information flow, the Chinese government would have been unlikely to be receptive to FOI reform. In the previous highly asymmetrical Chinese information environment, information flow was very limited, and a secretive and reactive information management approach was favoured. FOI was incompatible with this environment. However, the Chinese information environment is now far less asymmetrical, as information has flowed in multiple paths, and so a more proactive disclosure approach is preferred. FOI was a beneficiary of this ameliorated information environment, and has helped create further conditions for reducing information asymmetries between citizens and the state. 
This chapter has three sections. Section one explores a secretive and reactive approach to crisis information management taken by the Chinese government in the previous highly asymmetrical information environment. Section two examines a more proactive disclosure approach to crisis information management taken by the Chinese government in the present information environment. The third section examines the role of improved information flow in the Chinese information environment in increasing China's capacity to accept FOI.

\subsection{The past: limited information flow in the Chinese information environment}

In the restricted Chinese information environment of the past, a secretive and reactive approach to crises dominated for a long period of time. The intent of the Chinese government was to maintain social stability in China. ${ }^{1}$ The incompatibility of FOI with this form of information management proved a major obstacle to Chinese FOI reform. Information flow was very restricted due to social or cultural factors (Figure 2). A highly asymmetrical information environment with limited and very controlled information flow supported a secretive and reactive approach to crises. This created a hostile, if not incompatible, environment for transparency reform. Thus, there needed to be significant information environment changes and adaptations to the FOI process in order to give FOI reform a workable foothold in the Chinese information environment.

Social stability has been regarded by Chinese political leaders as a prerequisite for reform and development since the late 1970 s. Chinese political leaders have stated that 'stability is of overriding importance' and 'nothing can be achieved without stability'. See Xiaoping Deng, Selected Works of Xiaoping Deng (Volume III) (in Chinese) ( $2^{\text {nd }}$ ed, 1994) 364; Zemin Jiang, 'Hold High the Great Banner of Deng Xiaoping Theory for an All-round Advancement of the Cause of Building Socialısm with Chinese Characteristics to the $21^{\text {st }}$ Century' (in Chinese) (Speech delivered at the $15^{\text {th }}$ National Congress of the CPC, Beijing, 12 September 1997); Jintao $\mathrm{Hu}$, 'Hold High the Great Banner of Socialism with Chinese Characteristics and Strive for New Victories in Building a Moderately Prosperous Society in All Respects' (in Chinese) (Speech delivered at the $17^{\text {th }}$ National Congress of the CPC, Beijing, 24 October 2007). 


\section{Figure 2 Limited information flow in the Chinese information environment}

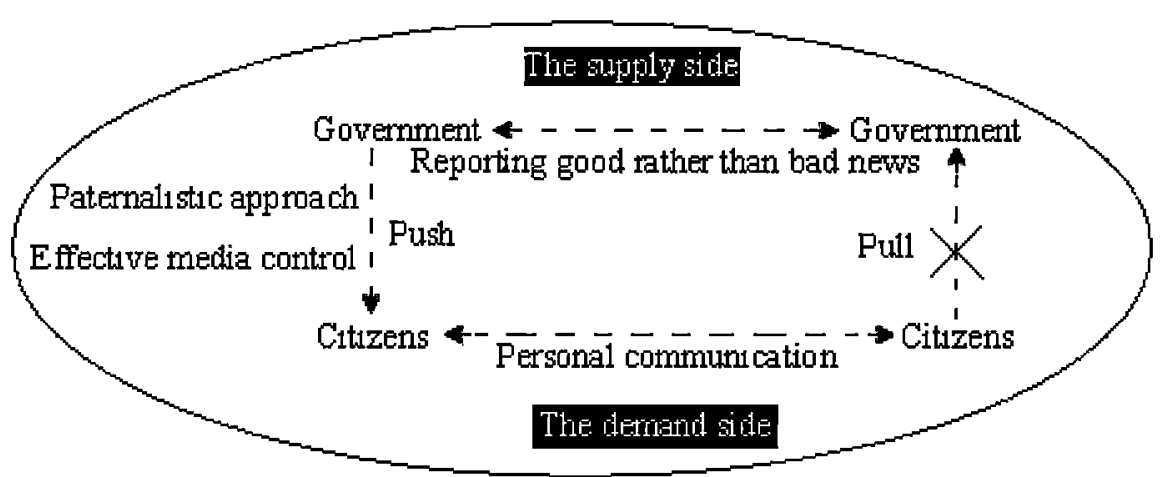

Note. dashed lines used in the figure to show limted information flow The mark $(x)$ means no flow.

\subsubsection{Information flow within government: reporting good, rather than bad news}

Chinese government officials began the process of 'reporting good, rather than bad news' (Bao Xi Bu Bao You) ${ }^{2}$ to deal with crises, indicating a reluctance to share information. The reporting of good, rather than bad news has been embedded in Chinese society ${ }^{3}$ with its roots in Confucianism. Confucius said that anyone working in the bureaucracy should speak prudently to avoid accusation. ${ }^{4} \mathrm{He}$ argued that the more one said the more one would be defeated (Duo Kou Duo Bai). ${ }^{5}$ These

2 Zhihao Lou, The Choice of the People (in Chinese) ( $1^{\text {st }}$ ed, 1991) 129.

3 Hongzhang $\mathrm{Li}$, a viceroy in the Qing Dynasty, serves as an example to illustrate this statement. Li was interviewed by a journalist in the New York Times in 1896. When asked whether China would introduce a newspaper system similar to that in the western world, he answered that ' $\mathrm{t}]$ here are newspapers in China, but the Chinese editors, unfortunately, do not tell the truth. They do not, as your papers, tell "the truth, the whole truth, and nothing but the truth." The editors in China are great economizers of the truth; they tell only a part of it...' See 'Li on American Hatred' The New York Times (New York) 3 September 1896, 10. In May 1896, Li visited Russia and took part in a coronation ceremony. When he saw many people in the crowd were crushed to death due to massive disorder, he asked Russia's Minister of Finance whether he would report everything he saw to his Emperor or not. The Minister said yes, but $\mathrm{Li}$ responded that according to his experience, he would not do the same thing and choose to conceal each bad thing he saw or knew from the emperor in order not to cause the emperor distress. See Qingiun Jia, 'Introduction of Experience in Russia by Hongzhang Li' (in Chinese) (2004) 8 Insight China 73, 74.

4 Confucius, Verse 18 of Chapter 2 in Lun $Y u$. See http://www.guoxue.com/jinbu/13jing/lunyu/ly 0 02.htm.

5 Xiang Liu, Shuo Yuan: Jin Shen. See http://www.shuku.net/novels/classic/shuoyuan/shuoyuan10. $\underline{\text { html. }}$. 
aphorisms were generally ingrained in many Chinese government officials. ${ }^{6}$ Current officials have also learnt from Deng's warning on 'saying less and doing more ${ }^{, 7}$ to avoid criticism or expose their fallibility and incapacity, but neglected the original purpose of the warning, which was for reducing formalism, a form of bureaucratism. ${ }^{8}$

The reporting of good, rather than bad news was strengthened by government officials' capacity to control information flow. ${ }^{9}$ The highly hierarchical and scattered nature of bureaucracies resulted in government agencies' extreme monopoly on crisis information. Officials considered that most bad news could be concealed effectively. ${ }^{10} \mathrm{~A}$ widely known case is the mine water leakage disaster in Nandan in 2001 , when one of the leaders struck his chest as a gesture of a 100 percent guarantee that it would not be made public. ${ }^{11}$ This showed a restriction on information flow within public administration.

6 Kong Guang is a good example to illustrate this point. Kong Guang, a former official working in Shanshu authority, was known as a very cautious and secretive person who learned from the ideas of his ancestor, Confucius. When one of his friends once asked him about what kinds of trees were planted in front of his office, he ignored this question and changed the subject immediately. Shanshu was responsible for delivering official documents between the emperor and senior officials. See Gu Ban, Han Shu: The Biography of Kong Guang. See http://www.guoxue.com/shib u/24shi/hansu/hsuml.htm.

7 Deng, above $\mathrm{n} 1,382$.

8 Fei Yi, Don't Misunderstand Deng's Warning on 'Saying Less and Doing More' (in Chinese) (2007) Xinhua Net <http://news.xinhuanet.com/comments/2007-02/09/content_5712689.htm> at 23 March 2009.

9 Zhongchang Li, 'The Relationship between FOI and the Right to Know' (in Chinese) (2003) 10 News Knowledge 16, 16.

10 China Central Television, 'Guoqing Wang Talks about the Spokesperson System', People in the News, 13 July $2007<$ http://news.cctv.com/china/20070713/109210.shtml> at 7 August 2007.

11 The disaster occurred in Nandan on 17 July 2001, causing 81 fatalities. The leadership in Nandan County decided to hide this catastrophe through various methods after they became aware of this disaster. They also reported inaccurate information to the superior government. They considered that the fact of this disaster was impossible to be discovered. The disaster was finally exposed by courageous journalists from People's Daily. The major players in this scandal were all punished severely. The Secretary of CPC Nandan County Committee was executed. See Xinghang Huang et al, 'I Am an Ungrateful and Disloyal Man' (in Chinese) People's Court Daily (Beijing) 21 February 2004, 4; Guizhan Ren, The Mine Water Leakage Accident in Nandan County and Its Lessons (in Chinese) (2002) People Net <http://www.people.com.cn/GB/shehui/212/6048/6320/2 0020109/644953.html>at 15 April 2008. 


\subsubsection{Information flow among citizens: limited threats to social stability by rumours}

In the past, the flow of crisis information among citizens was limited, as personal communication via word of mouth appeared to be the only way to share crisis information. The majority of people were thus kept in ignorance of crises. Whilst the lack of reliable information from the government made room for the spread of rumours or unverified explanation for crises, ${ }^{12}$ threats to social stability by rumours were limited. Although rumours can prompt social panic and destabilise society, ${ }^{13}$ the pace and distance of rumour transmission was constrained by the personal communication method. Furthermore, an effective filter role ${ }^{14}$ played by the traditional news media prevented mass communication from becoming a tool for spreading crisis information and rumours.

\subsubsection{Information flow from the government to society: a paternalistic approach}

The paternalistic approach, which concealed crisis information from its citizens, was justified by the perception of Chinese government officials about the low psychological endurance of the masses. ${ }^{15}$ The fear was that informed masses could

12 According to Peterson and Gist, rumour means 'an unverified account or explanation of events, circulating from person to person and pertaining to an object, event or issue of public concern'. See Warren Peterson and Gist Noel, 'Rumour and Public Opinion' (1951) 57 The American Journal of Sociology 159, 159. The term rumour in this thesis is used to refer unverified explanation for crises that can affect social stability. Allport and Postman argue that the quantity of rumours in circulation depends on two factors: the importance of the news and the ambiguity of the evidence. The secretive and reactive approach contributes to the second factor. See Gordon Allport and Joseph Postman, The Psychology of Rumour ( ${ }^{\text {st }}$ ed, 1947) 34.

13 Zhou argues that 'even a minor rumour can lead to turmoil in the whole society'. See Hanhua Zhou, 'Open Government in China: Practice and Problems' in Ann Florini (ed), The Right to Know: Transparency for an Open World (2007) 92, 106.

14 McQuail first argued that one of mediation roles was a filter or gatekeeper. See Denis McQuail, McQuail's Mass Communication Theory $\left(5^{\text {th }}\right.$ ed, 2005) 83.

15 Lidan Chen and Junni Chen, 'On Impediments to Information Flow during the Crisis of the Songhuajiang River Contamination' (in Chinese) (2005) 6 Press Circles 19, 21. This paternalistic approach was also previously favoured by some western governments. Meijer observes that the Netherlands governments 'were not used to open communication about risks. Before the fireworks factory exploded in the year 2000, many local governments argued that it was better to not actively inform citizens about risks in their direct environment since this could lead to irrational 
hold different ideas, express disagreement with each other, and live in a state of panic during crises, which could in turn destabilise society. Ruling the people by concealment or through parent officials (Fumu Guan $)^{16}$ was an idea embedded in the ruling philosophy of the rulers throughout 2000 years of China's imperial history. Confucius said that 'the common people may be made to follow, but may not be made to know' (Min Ke Shi You Zhi, Bu Ke Shi Zhi Zhi). ${ }^{17}$ Lao Zi, the founder of Daoism, ${ }^{18}$ also said that ' $[\mathrm{t}]$ he ancient followers of Tao did not use it to increase knowledge, but rather to preserve simplicity. People are difficult to govern when there is too much knowledge. Whoever rules a country by furthering knowledge is that nation's curse... ${ }^{19}$ Shu opposed the disclosure of criminal law by Chan $\mathrm{Zi}$ in the Zheng Kingdom in BC 536 in China, stating that the masses would argue about the meaning of the terms set out in the law if they knew them. ${ }^{20}$ Many examples can be used to illustrate this cultural influence. The crisis of the Songhuajiang River contamination in 2005 is a recent and widely known case in point. ${ }^{21}$

As a result, Chinese government officials generally processed a crisis before or without any information disclosure, ${ }^{22}$ as they held that only the concealment of crisis

fear in their communities. The general opinion was that governments should take appropriate measures and develop plans to protect citizens against risks, but citizens did not have to know about these risks. The general attitude was a paternalistic one'. See Albert Jacob Meijer, 'Risk Maps on the Internet: Transparency and the Management of Risks' (2005) 10 Information Polity $105,107$.

16 The term parent officials was used to call on officials to parent the people they ruled. This is a political heritage of Confucianism with a slight change in today's China.

17 Confucius, Verse 9 of Chapter 8 in $L u n Y u$. See http://www.guoxue.com/jinbu/13/nng/lunyu/ly 00 8.htm.

18 Daoism refers to a wide range of Chinese philosophical and religious concepts and had a strong influence on Chinese in ancient China. Dao refers to the way. The core concept of Daoism is Wu Wei, which means that let nature take its course.

19 Lao Zi, Chapter 65 in Tao De Jing. See http://www.guoxue.com/zibu/zibu zhuzıml/laozi.htm.

20 This was the first time for China to make criminal law public. Qiuming Zuo, Year 6 of Emperor Zhao in Chunqiu Zuozhuan. See http://www.guoxue.com/jinbu/13jing/cqzz/cqzz 009.htm.

21 In November 2005, the Songhuajiang River was contaminated with toxic benzene emitted by explosions at a chemical plant in Jilin Province. This resulted in several days' shutdown of water supplies to the downstream city of Harbin. To conceal the real reason, the Harbin government initially told a white lie to the residents that the shutdown was caused by routine repairs on pipes. Zuoji Zhang, the former Governor of Heilongjiang Province, confessed that one major reason for doing so was the government's worry about low endurance of the public. See Yulian Lai, 'The Harbin Government Works out the Emergency Plan for Water Supply' (in Chinese) Heilongjiang Daily (Harbin) 22 November 2005, 1.

22 Chen and Chen, above n 15. 
information could contain public panic and maintain social stability. ${ }^{23}$ According to the officials, the involvement of journalists added trouble to an already bad situation. $^{24}$

Furthermore, the government's capacity to control information flow in the preInternet age was strong. It was able to suppress information by enforcing constraints on the traditional news media, which were previously the single channel for the public to obtain information. News reports were guided by the principle of 'the news, old news or no news' (Xinwen, Jiuwen, Buwen), ${ }^{25}$ first mentioned by Chairman Mao in 1957. The principle means that the release of some news should be timely, but the release of other news should be postponed or even deliberately ignored. ${ }^{26}$ This became a key principle for the Chinese Party media to produce news reports. ${ }^{27}$ The reporting of many crises occurred before the early 2000s, such as the Tonghai earthquake, the Tangshan earthquake and the plague of Hepatitis A virus in Shanghai followed this principle. ${ }^{28}$

Thus, the capacity to accept FOI in the highly asymmetrical or secretive information environment was weak. This was due to low willingness of the government to share crisis information with its citizens and a strong capability to control flow of crisis information. There was a direct and serious incompatibility between any form of FOI and the secretive crisis information management process coupled with the issues of

23 Dalin Sheng, 'It Is Encouraging to Find That the Government Has Not Covered up Sensitive Events' (in Chinese) Qilu Evening (Jinan) 19 November 2008, A2.

24 Yuchuan Mo, 'How Can Power Be Exercised Well in a Transparent Way' (in Chinese) Legal Daily (Beijing) 13 February 2008, 3.

25 Zedong Mao, Selected Works of Zedong Mao on Journalism (in Chinese) $\left(1^{\text {st }}\right.$ ed, 1982) 193.

26 Ibid.

27 Guoming $Y u$, 'Guaranteeing the People's Right to Know Is the Fundamental Principle for Building the State's Information Security System' (in Chinese) (2003) 6 Practical Journalism 27, 27.

28 The death toll of the Tangshan earthquake in 1976 was not disclosed to the public until 17 November 1979, when it was revealed there were over 240,000 fatalities. See Xuejiang Xu, 'Death Toll of the Tangshan Earthquake Is More Than 240,000' (in Chinese) People's Daily (Beijing) 23 November 1979. The death toll of the Tonghai earthquake, which occurred in 1970, was not publicised until 5 January 2000 on its $30^{\text {th }}$ anniversary. The number topped 15,621 . See 'The Tonghai Earthquake Was Declassified after 30 Years' (in Chinese) Digest (Shanghai) 16 January 2000, 3. The Plague of Hepatitis A virus in Shanghai occurred in 1988, infecting 292,301 individuals. The media was not allowed to report it during that period. See Meidong Cheng, Reflection on Major Crises in Contemporary China (in Chinese) ( $1^{\text {st }}$ ed, 2008). 
regime stability and survivability.

\subsection{The present: improved information flow in the Chinese information environment}

The incompatibility of FOI with the macro information environment has lessened since the early $2000 \mathrm{~s}$. The secretive and reactive approach has been challenged by an improved information environment where information flow is more frequent (Figure 3). New media of communication have not only created difficulties for the government to conceal crisis information, but facilitated flow of crisis information within the demand side, such as media, citizens and civil society. New media have also increased rumours in circulation and their pace of distribution, and in turn increased threats to social order by rumours. These factors have triggered a reassessment of the efficiency and desirability of a secretive and reactive approach. Thus, guidance of public opinion (see 3.2.3), which is an approach to involve the government in the improved information environment or the emergent Chinese 'network society, ${ }^{29}$ to retain the power of agenda setting, ${ }^{30}$ has risen to the top of the political agenda. This has increased the government's willingness and capacity to share information with the demand side.

29 Sociologist, such as Manuel Castells and Jan van Dijk, developed the idea of a 'network society' which refers to 'a society where the key social structures and activities are organised around electronically processed information networks'. See Harry Kreisler, Interview with Manuel Castells (Berkeley, 9 May 2001) and Jan van Dijk, The Network Society: Social Aspects of New Media ( $2^{\text {nd }}$ ed, 2006) 20. Castells argues that there is no centre in an ideal network society, which 'works on a binary logic: inclusion/exclusion. All there is in the network is useful and necessary for the existence of the network'. See Manuel Castells, 'Materials for an Exploratory Theory of the Network Society' (2000) 51 British Journal of Sociology 5, 15.

30 The notion of agenda-setting was first formulated in a precise form and tested by Maxwell McCombs and Donald Shaw. See Maxwell McCombs and Donald Shaw, 'The Agenda-Setting Function of Mass Media' (1972) 36 Public Opinion Quarterly 176-87. Cohen argues that '[t]he press may not be successful much of the time in telling people what to think, but it is stunningly successful in telling its readers what to think about'. See Bernard Cohen, The Press and Foreign Policy (1 ${ }^{\text {st }}$ ed, 1963) 120. 


\section{Figure 3 Improved information flow in the Chinese information environment}

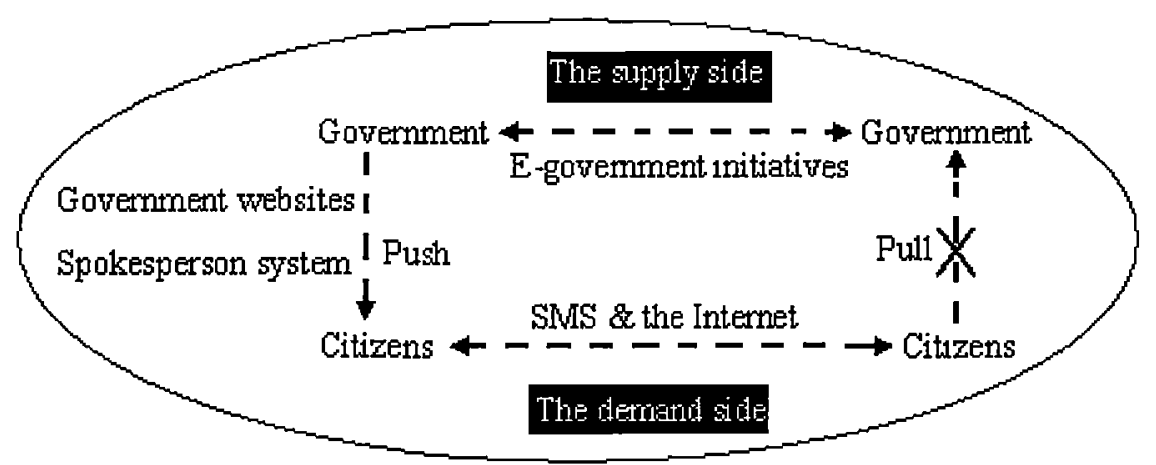

Note: thicker lines used in the figure to show improved information flow. The mark ( $x$ ) means no flow.

\subsubsection{Information flow among government: improved by e-government projects}

Informatisation programs, especially e-government ${ }^{31}$ projects, have increased flow of information in public administration. The previously hostile information environment for transparency reform has begun to move to a direction that can encourage an increase in information flow. The development of informatisation, a new mode of developing China's economy (see 6.1.1), can be traced to the 1980s, when the Chinese government conducted the office automation project among all government agencies. ${ }^{32}$ The starting point of a series of incremental information infrastructure

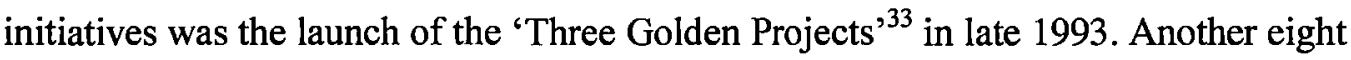

31 The World Bank defines e-government as 'the use by government agencies of information technologies (such as Wide Area Networks, the Internet, and mobile computing) that have the ability to transform relations with citizens, businesses, and other arms of government'. See The World Bank, Definition of E-Government <http://web.worldbank.org/WBSITE/EXTERNAL/TOP ICS/EXTINFORMATIONANDCOMMUNICATIONANDTECHNOLOGIES/EXTEGOVERNM ENT/0,,contentMDK:20507153 menuPK:702592 pagePK:148956 piPK:216618 theSitePK:702 $586,00$. html $>$ at 14 September 2009.

32 The Development of Government Informatisation in China (in Chinese) (2003) China Net $<$ http://www.china.com.cn/chinese/zhuanti/283258.htm> at 19 May 2008.

33 Golden Bridge is the infrastructure for informatising the national economy. Golden Customs is used to create an integrated data communications system connecting foreign trade companies, banks, and customs and tax agencies. Golden Card aims at creating a unified payment clearance system to allow the widespread use of credit and debit cards across the whole country. See Peter Lovelock and John Ure, 'Assessing China's Efforts in Constructing an E-Government' in Junhua Zhang and Martin Woesler (eds), China's Digital Dream (2002) 151, 152. 
e-government projects that cover a wide range of government functions have been initiated in China since these original projects. ${ }^{34}$ The Government Online Project was formally launched in China in 1999 (see 3.2.3), presenting the opportunity for greater information flow. ${ }^{35}$

Whilst the improvement of information flow within the supply side does not directly increase the prospects of transparency reform, the rising information flow in public administration remains a relevant shift. This has partially prevented lower levels of government agencies from taking advantage of their previous extreme monopoly on crisis information as the hierarchical and scattered nature of bureaucracies has been diminished. ${ }^{36}$ The increasing information sharing among government agencies advanced by e-government projects has also increased the central government's capacity to release more reliable information to the public.

\subsubsection{Information flow among citizens: improved by new media}

New media, such as the Internet and cell phones, have been widely used by Chinese citizens (Table 2), increasing citizens' capacity to communicate directly with one another. This emergent interactive information network ${ }^{37}$ has challenged the traditional secretive and reactive information management approach. New media have also assisted rumour and information transmission, potentially increasing the threat to social stability. Enhanced information flow among citizens has prompted the Chinese government to become more transparent and proactive, thus opening up the

34 The Guidance on the Leading Group of National Informatisation for China's E-Government Construction No 17 [2002] of the General Office of the CPC Central Committee.

35 Cheng argues that the government online project and the like have caused the government to be more observable, and this has prompted the government to encourage communication and consensus in order to adapt to the changed information environment. See Jie Cheng, 'Toward Open Society: Examination on Policies Concerning Access to Public Information and Openness in Government Affairs' (in Chinese) (2002) 3 Tsinghua Forum of Rule of Law 460, 473. Taylor argues that information and communication technologies 'bring a networking logic into the organisational world'. See John Taylor, 'Informatisation as X-ray: What Is Public Administration for the Information Age?' in I.Th.M. Snellen and W.B.H.J.van de Donk (eds), Public Administration in an Information Age: A Handbook (1998) 21, 24.

37 Castells defines information networks as 'social networks which process and manage information ... using micro-electronic based technologies'. He argues that information networks are 'the predominant organisational form' and 'the backbone of the network society'. See Kreisler, above n 29; Castells, above n 29, 16-7. 
possibility of experimenting with the push aspect of FOI or proactive disclosure.

\section{Table 2 The use of the Internet and cell phone in China}

\begin{tabular}{||l|l|l||}
\hline \hline USE OF THE INTERNET & $\mathbf{1 9 9 7}$ & $\mathbf{2 0 0 7}$ \\
\hline Number of users of the Internet & 620,000 & 210 million \\
\hline Internet penetration rate & 0.1 percent & 16 percent \\
\hline Bulletin Board System & Nil & 1.3 million \\
\hline Blogs & Nil & 47 million \\
\hline Annual growth rate of netizens & About 20 percent & \\
\hline USE OF CELL PHONE & $\mathbf{2 0 0 0}$ & $\mathbf{2 0 0 7}$ \\
\hline Number of cell phones & 0.14 billion & 0.55 billion \\
\hline Penetration rate of cell phones & 6.77 percent & 41.6 percent \\
\hline Number of Short Message Services (SMS) messages & 15 billion (2001) & 592.1 billion \\
\hline
\end{tabular}

Source: China Internet Network Information Centre Statistical Survey Report on the Internet Development in China and the Ministry of Industry and Information Technology

\section{New media: enabling citizens to share agenda setting power with traditional media}

New media have made it possible for ordinary citizens to become citizen journalists, giving a relatively free and convenient platform for citizens to share crisis information, even without flow of crisis information from the government. New media have assisted Chinese citizens to overcome technical and financial obstacles to produce news reports, ${ }^{38}$ enabling almost anyone to become a comparatively independent media source. This guarantees the dissemination of those articles that cannot be published by the traditional media. The article that exposed the mine water leakage disaster in Nandan was first published on the electronic media, People's Daily Online, rather than the newspaper, People's Daily. ${ }^{39}$ In the 2008 Sichuan earthquake, the first live video was recorded by a cell phone and posted to the Internet by a university student within 10 minutes of the quake and eight minutes prior to the official announcement. ${ }^{40}$

38 Weizhong Wu and Xiaohua Li, 'Weak Supervision of the Short Message Communication' (in Chinese) (2006) 12 Journal of Harbin University 85, 88.

39 Ren, above n 11. People's Daily Online was launched by People's Daily in 1997 to disseminate news about China.

40 The video was first posted to Tudou, similar to Youtube. It had roughly 1.8 million hits and was forwarded by international media groups, such as CNN and BTV. See http://www.tudou.com/programs/view/4az14njs2X4/. 
The government has encountered technological difficulties in controlling information flow efficiently. Internet censorship exists in China, ${ }^{41}$ but it "cannot keep up with the spread of information', ${ }^{42}$ and so it has become 'increasingly difficult for the government to regulate what information is accessed ${ }^{43}$ Some officials confess that 'we can prevent one journalist from reporting bad news, but we cannot prevent all journalists from doing so; or even if we can require all journalists not to report bad news, we are still incapable of asking all netizens not to expose it ${ }^{44}$ This indicates that in an improved information environment where information flows in multiply ways, it is difficult for the government to censor information. ${ }^{45}$

As a result, ordinary citizens also have the power to set agendas that were previously tightly controlled by government news media. Now, they are information consumers and creators. Thus, the 'interactive audience' supersedes 'the mass audience' coupled with the mass media. ${ }^{46}$ All cell phone users and netizens or Internet users have the capacity to set the agenda for others, diminishing the government's monopoly on agenda setting. The emergency of a decentralised agenda setting power has challenged the secretive and reactive approach. The Severe Acute Respiratory Syndrome (SARS) crisis provides a good example. ${ }^{47}$ Chinese citizens used cell

41 Derek Bambauer et al, 'Internet Filtering in China in 2004-2005: A Country Study' (Research Publication No 2005-10, Berkman Centre for Internet \& Society at Harvard Law School, 2005). See http://papers.ssrn.com/sol3/papers.cfm?abstract id=706681. Helen Margetts, 'Transparency and Digital Government' in Christopher Hood and David Heald (eds), Transparency: The Key to Better Governance? (2006) 197, 199. John Gittings, The Changing Face of China: From Mao to Market $\left(1^{\text {st }}\right.$ ed, 2005) 8-9.

Ibid.

44 Huaxin Zhu et al, 'Analysis Report on Public Opinions on the Internet in China in 2007' (in Chinese) (2008) 2 Today's Mass Media 31, 36.

45 Castells argues that '[t]he only way to control the network is not to be into it, and this is a high price to pay for any institution or organisation once the network becomes pervasive and channels all kinds of information around the world'. See Manuel Castells, The Rise of the Network Society $\left(1^{\text {st }}\right.$ ed, 1996) 352.

46 Castells, above n $29,12$.

47 The SARS crisis occurred in China between November 2002 and August 2003, causing 5327 individuals infected with SARS and 349 fatalities. According to the Guangdong Mobile Communication Co., Ltd., there were 40 million text messages on 8 February 2003, with an increase of one million on the next day, and five million on 10 February. Most of these text messages were related to the outbreak of an unidentified fatal flu. See Guoqiang Yun and Pin Lv, The Relationship between the Media and the Government: Taking the Example of the SARS Incident (in Chinese) (2003) $21^{\text {st }}$ Century <http://www.cuhk.edu.hk/ics/21c/supplem/essay/03040 69.htm>at 21 April 2008. 
phones to forward messages about an unknown fatal flu at a time when they could not obtain reliable information from the traditional media and the government. ${ }^{48}$ SMS messages aided them to overcome the influence of the agenda set by China Central Television, which reported heavily on the Iraq War at the time of the crisis. ${ }^{49}$

The strong public concern finally attracted the attention of the central government. After 20 April 2003, it required all levels of government to 'report information on SARS accurately, honestly, and in a timely manner'. ${ }^{50}$ The central government warned that harsh punishment would be imposed for any delay or concealment, as proved by the fact that the Minister of the Health Ministry and Mayor of Beijing were dismissed for their concealment of information on SARS patients. ${ }^{51}$ In an improved information environment where alternative information sources, such as citizen journalists, can provide reliable crisis information to the general public, government officials will pay huge financial and public-trust costs for concealing information. This has prompted the Chinese government to become more transparent and proactive in dealing with crises.

\section{New media: increasing threats to social stability by rumours}

New media have increased threats to social stability by rumours or unverified explanation for crises. This has prompted the Chinese government to become more transparent and proactive in order to diminish the negative impact of rumours. New media have advanced the pace and distance of rumour transmission within the demand side. ${ }^{52}$ Wang asserts that in the information era, a rumour already travels around half of the earth when the truth still remains unknown. ${ }^{53}$ There is a vast difference between 1000 users of new media and more than 200 million

\footnotetext{
48 Gittings, above $\mathrm{n} 42$.

49 Mu Qiao, 'The Communication Effect and Political Impact of SMS Messages' (in Chinese) (2008) 4 Contemporary Communications 76, 76.

50 Ling Lan, 'Open Government and Transparency Policy: China's Experience with SARS' (2005) 6 International Public Management Review 60, 63.

51 Ibid.

52 Sheng Li, 'The Background, Main Contents and Inventory Compilation concerning China's FOI Regulations' (in Chinese) (2008) 5 E-Government 21, 22.

53 China Central Television, above n 10.
} 
users. ${ }^{54}$ When so many users interact with others via the Internet or SMS, many unexpected things occur. Thus, late or reactive disclosure of crisis information will provide an opportunity for rumours to spread quickly and influence public opinion at first due to the primacy effect, which means that 'the message presented first exerts a disproportionate impact on an individual's opinion'.55

Furthermore, new media via varied real-time communication tools ${ }^{56}$ have allowed rumours to spread much more extensively, as they combine personal communication with mass communication. In the past, rumours could have only spread via personal communication, but this is not the case now. Mass communication, another feature of new media, ${ }^{57}$ is used nowadays to transmit rumours, and so rumours can appear in 'the collective mind'. ${ }^{58}$ In addition, new media are based on personal communication. ${ }^{59}$ They consequently have a higher rate of receipt, readership ${ }^{60}$ and participation than traditional media. ${ }^{61}$

Rising threats to society by rumours in the improved information environment have forced the Chinese government to abandon its old information management approach. It now recognises that rumours can be transformed and denied with reliable information release (Yaoyan Zhi Yu Gongkai), rather than the converse. ${ }^{62}$

54 China now has the largest size of netizens since June 2008, reaching 253 million. See China Internet Network Information Centre, The $22^{\text {nd }}$ Statistical Survey Report on the Internet Development in China (2008) <http://www.cnnic.cn/download/2008/CNNIC22threport-en.pdf> at 28 November 2008.

55 William Crano, 'Primacy versus Recency in Retention of Information and Opinion Change' (1977) 101 Journal of Social Psychology 87, 89.

56 Such as QQ, MSN and Bulletin Board System. QQ is the most popular free instant messaging computer program in China. The number of current users is about 340 million.

57 Xiang Hao, "SMS Messages - The Communication Potential and Development Problems of "the Fifth Medium"' (in Chinese) (2006) 1 Southeast Communication 15, 15.

58 Castells argues that 'in a society organised around mass media, the existence of messages that are outside the media is restricted to interpersonal networks, thus disappearing from the collective mind'. See Castells, above n $45,336$.

59 Hao, above n 57.

60 Yinghui Zhang, 'The Incapability of Controlling the Transmission of SMS Messages and the Solutions' (in Chinese) (2008) I News Window 104, 105.

61 Qiao, above n 49, 77.

62 "FOI" Is the Prelude to Civil Society' (in Chinese) Southern Daily (Guangzhou) 15 February 2007, A02. 


\subsubsection{Information flow among citizens: precondition for the push aspect of FOI}

China's capacity to support the push aspect of FOI has increased due to the following three factors. First, increasing information flow among citizens has created difficulties for the Chinese government to conceal information (see 3.2.2). The secretive and reactive approach is outdated and should be changed. Second, the government has increased its willingness to share crisis information with the public. It has recognised the importance of guiding public opinion or setting agendas for others. Third, the capability of the government to actively disseminate information to the demand side has been strengthened by the launch of spokesperson systems and government websites.

\section{Increasing willingness to proactively disclose information}

The Chinese government wants to retain the power to guide public opinion. This has increased its receptivity to the push aspect of FOI. The secretive and reactive approach has resulted in the government losing the power to set agendas for others. Whilst it is possible for the government to regain the initiative of agenda setting, the price will be high. ${ }^{63}$ Therefore, guidance of public opinion has been regarded as an important measure to assist the Chinese government in improving its governance capability. ${ }^{64}$ This view calls for more proactive disclosure to retain the power of agenda setting. The Chinese government cannot guide public opinion if it persists in

63 The Centre for International Communications Studies of Tsinghua University, 'The Ruling Capability of the Chinese Government and the Institutionalisation of Spokesperson Systems' (in Chinese) (2005) 8 Today's Mass Media 7, 7.

64 The Decision of the CPC Central Committee on Strengthening the Building of the Party's Ruling Capability No 18 [2004] of the Central Committee of the CPC. The Chinese government has recognised the importance of guidance of public opinion since the political turmoil of 1989 . Jiang states that 'correct guidance of public opinion is good for both the Party and the people'; and incorrect guidance is potentially disastrous for both. See Zemin Jiang, Selected Works of Zemin Jiang (Volume I) (in Chinese) ( $\left.1^{\text {st }} \mathrm{ed}, 2006\right)$ 501, 563. President Hu reiterates this importance, cautioning that 'correct guidance benefits the Party, the nation and the people'; and incorrect guidance, in turn, is prone to injuring all of them. See Jintao Hu, 'Speech Delivered at the Visit to People 's Daily' (in Chinese) People's Daily (Beijing) 20 June 2008, 4. 
the secretive and reactive approach in the improved information environment. ${ }^{65}$ President $\mathrm{Hu}$ thus has urged the Party media to actively set the agenda for others to respond to crises. ${ }^{66} \mathrm{Wu}$ Cai, the former Director of the State Council Information Office, has called on government officials to alter their mindset of concealing information to manage crises. ${ }^{67}$ Yangwu Ou, the Deputy Director of the State Council Informatisation Office and a member of drafting FOI legislation, said in an FOI seminar that 'information disclosure has the role of ruling out rumours and guiding public opinion. Others are keen to take full advantage of this mechanism. Why does the government not want to do this? ${ }^{98}$ This comment by Ou is significant because it indicates that only a more transparent and proactive approach can aid the Chinese government to adapt to the improved Chinese information environment.

Some Chinese scholars observe that crises, especially the 2003 SARS crisis, accelerated the legislative process of FOI in China ${ }^{69}$ However, this thesis argues that the way the public responded to crises by using information technology to share crisis information has changed in recent years. This encouraged the government to reconsider its approach to crisis information management. FOI then became a more useful tool in a more open environment. Arguably, it is a more open environment, rather than the crises that created the necessity for FOI reform. The Chinese government recognised that it would be in its interest to become more transparent and active in managing crises.

The rising willingness for more proactive crisis information disclosure has reversed the previous concern about a low psychological endurance of the public (see 3.1.3), and helped smooth the adoption of FOI legislation in China. Zhou argues that if Chinese political leaders had not considered that information release benefited social

65 China Central Television, above n 10; Li, above n 52, 22-3.

$66 \mathrm{Hu}$, above $\mathrm{n} 64$.

67 Wu Cai, Speech delivered at the Fourth National Spokespersons Training Session, Beijing, 2 December 2005.

68 Yangwu Ou, Speech delivered at Seminar on the FOI Regulations, Beijing, 17 March 2007. See http://www.hongfan.org.cn/file/upload/2007/03/17/1215097825.pdf.

69 Such as Professor Hanhua Zhou and Datong Li. See footnote 72 in Chapter 1. 
stability, the current extent of FOI reform would have been difficult to achieve. ${ }^{70}$ Political leaders have shifted their views about the relationship between information disclosure and social stability from mutually exclusive toward mutually inclusive. Article 6 of China's FOI Regulations, in particular, reflects this changed view. This Article requires government agencies to release accurate information in order to rectify any false or incomplete information that has affected or may affect social stability, and that has disturbed or may disturb social management order. ${ }^{71}$

\section{Increasing capability to proactively disclose information}

The Chinese government has not only recognised the importance of proactive disclosure, but has improved its proactive disclosure systems since the early 2000s. The government has revised and adopted several specific laws and regulations to legislate on proactive disclosure of crisis information. These measures have increased the government's capability to share information with the public, thus preparing the ground for the Chinese government to consider a push model of FOI legislation (see Chapter 8). There are three key features to this increased capability.

First, many government agencies have established the spokesperson system since 2003. This has provided a basis for the Chinese government to legislate on proactive disclosure. The State Council Information Office has pursued the establishment and improvement of news briefing and spokesperson systems as its central task in recent years. ${ }^{72}$ This made slow progress until the SARS crisis, which accelerated the progress. ${ }^{73}$ The former director of the State Council Information Office argues that spokespersons, who are the guides of the Chinese and foreign media outlets to report on China, play a vital role in promoting government information release. ${ }^{74}$ As a result, press conferences are laid down in China's FOI legislation as an important way to

70 Hanhua Zhou, Speech delivered at Seminar on the FOI Regulations, Beijing, 17 March 2007. See http://www.hongfan.org.cn/file/upload/2007/03/17/1215097825.pdf.

71 Freedom of Information Regulations 2007 (China) Art 6.

72 China Central Television, above n 10.

73 Ibid. By 26 September 2006, about 70 ministries and commissions of the State Council and 31 provincial governments had appointed their own spokespersons.

74 Bing Song and Wen Liu, 'Gradual Perfection of the Spokesperson System in China' (in Chinese) People's Daily Overseas Edition (Beijing) 7 November 2008, 1. 
actively disclose government information. ${ }^{75}$ Zhou argues that this arrangement is unreasonable since other countries' FOI laws rarely list press conferences as a formal way to disclose government information. ${ }^{76}$ However, his argument underestimates the need for the government to retain and build upon its capacity to set agendas. The legitimisation of press conferences in the FOI Regulations fits within a proactive approach to information management.

Second, many government agencies have launched official websites to increase information flow. The Government Online Project was initiated in early 1999 by more than 40 ministerial level agencies. ${ }^{77}$ This project prompted most government agencies to launch their own official websites (Table 3 ). ${ }^{78}$ More importantly, the central government launched its official web portal in late 2005. The number of Chinese government websites with the domain name gov.cn has increased, rising to 28,575 in 2007 , about 20 times as many as that of 1999 (1470). ${ }^{79}$ The central government has also determined to use government websites as the priority platform for actively distributing information. ${ }^{80}$

\section{Table 3 The percentage of websites launched by government agencies}

\begin{tabular}{|l|l|l|l||}
\hline GOVERNMENT AGENCIES AT VARIOUS LEVELS & \multicolumn{3}{|l|}{ YEAR AND PERCENTAGE } \\
\cline { 3 - 4 } & $\mathbf{2 0 0 5}$ & $\mathbf{2 0 0 6}$ & $\mathbf{2 0 0 8}$ \\
\hline Government agencies directly under the State Council & 96.1 & 96.1 & 96.1 \\
\hline Government agencies at the province level & 96.1 & 100 & 100 \\
\hline Government agencies at the county level & 77.7 & 83.1 & 99.1 \\
\hline
\end{tabular}

Source: The State Council Informatisation Office

Freedom of Information Regulations 2007 (China) Art 15.

Zhou, above $\mathrm{n} 70$.

Lovelock and Ure, above n 33.

78 The State Council Informatisation Office, Informatisation Development Report in China (in Chinese) (2006) E-Gov Net <http://www.e-gov.org.cn/ziliaoku/news003/200606/28025.html> at 22 June 2007.

79 China Internet Network Information Centre, $19^{\text {th }}$ Statistical Survey Report on the Internet Development in China (2007) <http://www.cnnic.net.cn/download/2007/cnnic19threport.pdf $>$ at 7 August 2008.

80 The Overall Framework of National E-Government No 2 [2006] of the State Council Informatisation Office. 
Third, many specific laws and regulations were adopted or revised to legislate on active distribution of crisis information. This has improved information flow in the Chinese information environment, preparing the ground for the Chinese government to accept FOI. Death tolls have been withdrawn from the list of state secrets, facilitating active disclosure of crisis information. In the past, death tolls were prohibited from disclosure as they fell into the category of state secrets. ${ }^{81}$ This prohibition remained unchanged until the issue of the Notice on Disclosure of Death Tolls and Related Natural Disasters Information in $2005 .{ }^{82}$ Since then, death tolls are allowed to be disclosed in a timely fashion. This has cleared the way for disclosure of crisis information.

The outbreak of SARS caused the State Council to introduce Regulations on Preparedness for and Response to Emergent Public Health Hazards in 2003. The Regulations provide a mechanism for ensuring release of information on the emergent hazard, requiring government agencies to disclose information in a timely, accurate and comprehensive manner. ${ }^{83}$ The Law on the Prevention and Cure of Infectious Diseases 1989 was modified in 2004. It has added SARS to the second class of infectious diseases, and improved the release system by requiring national and regional health agencies to regularly release information on the epidemic situation. ${ }^{84}$ The Criminal Law was also amended in 2006 , to provide a maximum sentence of seven years of imprisonment for those who fail to report or falsely report accidents endangering safety. ${ }^{85}$ These law reform initiatives have increased flow of crisis information from the government to society in China, creating more favourable environment for the consolidation of FOI legislation.

81 The Rules on the Scope of State Secrets and Secrecy Levels in the Work of Civil Affairs No 17 [2000] of the Ministry of Civil Affairs.

82 The Notice on Declassifying Death Tolls from Natural Disasters and the Related Information No 116 [2005] of the Ministry of Civil Affairs.

83 Regulations on Preparedness for and Response to Emergent Public Health Hazards 2003 (China) Art 25.

84 The Prevention and Cure of Infectious Diseases Law 1989 (China) Art 38.

85 The Criminal Law 1997 (China) Art 139. 


\subsection{A beneficiary of improved information flow: FOI legislation}

The preceding section demonstrates that information flow has improved in the Chinese information environment. This improvement has created a critical precondition for the acceptance of the push aspect of FOI, as explained in the following two points. First, the analysis of crisis information management demonstrates that it is necessary for the Chinese government to shift from a secretive and reactive information management approach to a proactive disclosure one. To achieve this shift, the institutionalisation of discretionary proactive disclosure is necessary. Spokespersons and official websites are useful platforms for government agencies to proactively disclose information to the public, but this disclosure depends on government agencies' discretion. ${ }^{86}$ Furthermore, if only official spokespersons are responsible for information disclosure, it will be insufficient to guide public opinion. ${ }^{87}$ The Chinese government realised that it was important for all government officials to have a certain level of media literacy and awareness. ${ }^{88}$ The desire to achieve this has necessitated the emphasis on the government's proactive disclosure duty ${ }^{89}$ by adopting a push model of FOI legislation in China.

Second, demand side players have increased their desire for greater information flow. New media have offered Chinese citizens the opportunity to expose and share their concerns about their immediate interests, like public health, in a series of crises. Chinese citizens have also changed their information expectations as they have increased their use of new media to access information, prompting the government to supply information actively or voluntarily. ${ }^{90}$ As a result, the Chinese government may have recognised that a push model of FOI legislation is necessary to adapt to the

Hanhua Zhou, 'FOI Regulations Will Bring about Six Changes' (in Chinese) People's Daily (Beijing) 14 February 2007, 13.

China Central Television, above $\mathrm{n} 10$.

88 Ibid.

89 Hai Qin, Speech delivered at Seminar on the FOI Regulations, Beijing, 17 March 2007. See http://www.hongfan.org.cn/file/upload/2007/03/17/1215097825.pdf.

90 Margetts, above n 41. Cuillier and Piotrowski also assert that 'reliance on the internet for information was positively associated with support for access to public records'. See David Cuillier and Suzanne Piotrowski, 'Internet Information-Seeking and Its Relation to Support for Access to Government Records' (2009) 26 Government Information Quarterly 441, 441. 
improved information environment.

The acceptance of the push aspect of information flow also provided an enabling or favourable environment for the acceptance of the pull aspect of FOI or reactive disclosure. Only after the government increased its desire to share information with the public, did the hostile or incompatible conditions for FOI reform lessen. Improved information flow in the Chinese information environment, together with political and legal factors, jointly resulted in the gradual shift from an emphasis on the push aspect to the pull aspect of FOI in China (see Chapters 4 and 5).

\subsection{Conclusion}

This chapter highlights that improved information flow in the Chinese information environment over time was critical to accept FOI. An exploration of crisis information management shows that improved information flow caused the Chinese government to abandon a secretive and reactive approach to information management, and instead to adopt a more proactive disclosure approach. This movement has ameliorated the Chinese information environment, and thus created a more favourable environment for FOI. Therefore, the traditional accounts of economic growth and anti-corruption efforts for China's FOI reform should be downplayed due to this important, but largely unexplored factor of information flow.

The next two chapters explore the roles of improved political and legal conditions in increasing China's capacity to accept FOI. 


\section{4: DEMOCRATISATION AS A RATIONALE FOR FOI REFORM IN CHINA}

\subsection{Introduction}

This chapter examines the influence of a long term democratisation process on China's capacity to accept FOI. It argues that FOI reform in China was conditional on the dynamics of incrementally upgrading openness practices associated with the democratisation reform agenda. The gradual promotion of openness practices improved information flow in the restrictive Chinese information environment, thus increasing the Chinese government's receptivity to the pull aspect of FOI. Government receptivity further increased after temporarily moving the concept of FOI away from an emphasis on media freedom, to an emphasis on information flow, including push/proactive disclosure and pull/reactive disclosure aspect of information flow. This helped abate serious concern over the incompatibility of FOI with China's Marxist-Leninist political system.

This chapter has four sections. The first section explores the formulation of an acceptable version of FOI that emphasises the benefit of increased information flow for China's one-party political system. It examines several factors that created concern about the political incompatibility of FOI with the Chinese political system and the gradual abatement of this concern. Section two discusses the role of openness in developing grassroots democracy. Section three explores the importance of Openness in Government Affairs (OGA) in developing socialist democracy. Section four examines the role of FOI Regulations in legislating on OGA. 


\subsection{A type of FOI emphasising information flow: an acceptable version}

Chinese reformers developed effective strategies to lessen the concern about the incompatibility of FOI with China's political system. This was achieved by finding ideological and constitutional evidence to demonstrate the compatibility of a type of FOI emphasising information flow with the Chinese political system. An important strategy was to temporarily uncouple FOI from freedom of expression. This aided the Chinese government to accept FOI as a particular form of information flow. The changing government response to freedom of expression from 2006 also favoured more positive reception to FOI (see 4.3.2).

\subsubsection{Sources of the incompatibility concern}

A narrow definition of FOI, closely intertwined with liberal democracy and freedom of expression, raised concern over the incompatibility of FOI with China's political system. The failure of Gorbachev's glasnost reform heightened this concern. Chinese reformers identified ideological and constitutional evidence, and uncoupled FOI from freedom of expression, at the initial stage of consideration, to lessen the incompatibility concern in the early 2000s, when FOI was still a politically sensitive term. $^{1}$

\section{A strong liberal democratic ethos of FOI}

FOI has strong perceived links to liberal democracy (see 1.1.1). It has been used as a tool for limiting government power ${ }^{2}$ and improving efficiency of public participation in political activities, including elections. ${ }^{3}$ The one-party or unelected leadership of the Communist Party of China (CPC) contradicts or is in opposition to these key

1 Hanhua Zhou, 'The Legislative History of FOI Regulations in China' (in Chinese) (2008) $7 E$ Government 15, 15.

2 Alasdair Roberts, Freedom of Information: From Millions to Billions (2008) Sunshine Week $<$ http://www.sunshineweek.org/sunshineweek/roberts08> at 2 October 2008.

3 Mendel states that ' $[\mathrm{f}]$ or elections to fulfil their proper function .... the electorate must have access to information'. See Toby Mendel, 'Freedom of information: A Comparative Legal Survey' $\left(2^{\text {nd }}\right.$ ed, 2008) 4 . 
attributes of FOI. Furthermore, a global move toward FOI has been promoted vigorously by many international organisations which 'share a commitment to Western liberal values', like the organisation known as Article 19, which campaigns for freedom of expression. This organisation took its name from Article 19 of the Universal Declaration of Human Rights, which states that '[e]veryone has the right to freedom of opinion and expression; this right includes freedom to hold opinions without interference and to seek, receive and impart information and ideas through any media and regardless of frontiers'. ${ }^{5}$ Many other international human rights instruments, such as the International Covenant on Civil and Political Rights and the American Convention on Human Rights were modelled on Article $19 .{ }^{6}$

The terms 'to seek, receive' under Article 19 of the Universal Declaration of Human Rights have been interpreted as the guarantee of public access to information. ${ }^{7}$ The United Nations Special Rapporteur on Freedom of Expression stated in 1998 that 'the right to seek, receive and impart information imposes a positive obligation on states to ensure access to information..., ${ }^{8}$ The right to know also forms part of many Commonwealth countries' constitutions as part of freedom of expression. ${ }^{9}$ National courts in Japan, ${ }^{10}$ India ${ }^{11}$ and Korea, ${ }^{12}$ and the Inter-American Court of Human

4 Colin Darch and Peter Underwood, Freedom of Information and the Developing World: The Citizen, the State and Models of Openness ( $1^{\text {st }}$ ed, 2009) 51.

The Universal Declaration of Human Rights Art 19.

6 Article 19 of the International Covenant on Civil and Political Rights and Article 13 (1) of the American Convention on Human Rights are alike to the expression found in Articles 19 of the Universal Declaration of Human Rights.

7 Peter Sebina, Freedom of Information and Records Management: A Learning Curve for Botswana (D Phil Thesis, University College London, 2006) 68.

8 Report of the Special Rapporteur, Promotion and Protection of the Right to Freedom of Opinion and Expression, E/CN.4/1998/40, 28 January 1998, Para 14.

9 The Commonwealth Human Rights Initiative, Open Sesame: Looking for the Right to Information in the Commonwealth (2003) <http://www.humanrightsinitiative.org/publications/chogm/chogm_ 2003/chogm\%202003\%20report.pdf> at 25 May 2007.

10 Information Clearinghouse Japan, Breaking down the Walls of Secrecy: The Story of the Citizen's Movement for an Information Disclosure Law (2002) Freedom of Information Organisation $<$ http://www.freedominfo.org/features/20020727.htm> at 26 July 2008.

11 S.P. Gupta v President of India and others etc. AIR 1982 SC 149.

12 Forests Survey Inspection Request Case, 1 KCCR 176, 88Hun-Ma22, September 4, 1989; Military Secret Leakage Case KCCR 64, 89Hun-Ka104, February 25, 1992. 
Rights and the European Court of Human Rights, ${ }^{13}$ have adjudged that the right to know is protected by the clause that guarantees freedom of expression under domestic constitutions or international human rights instruments.

FOI is therefore typically considered as an adjunct of freedom of expression ${ }^{14}$ or as the same as freedom of expression. ${ }^{15}$ Scholars observe that FOI and freedom of expression have been conflated so much so that they are difficult to separate. ${ }^{16}$ This concerned Chinese reformers, at least in the initial stage of consideration of FOI reform.

\section{The failure of Gorbachev's glasnost reform}

The failure of Gorbachev's glasnost reform ${ }^{17}$ in the former Soviet Union further raised doubts over the role of FOI in the development of socialist democracy in

13 Inter-American Court of Human Rights, Claude Reyes et al v Chile Judgment of September 19, 2006. The Inter-American Court of Human Rights was 'the first international tribunal to recognise a basic right of access to government information as an element of the right to freedom of expression'. See The Open Society Justice Initiative, Claude et al $v$ Chile (2007) $<$ http://www.justiceinitiative.org/db/resource2?res_id=102628> at 1 March 2009; The European Court of Human Rights followed suit recently in the cases of Társaság a Szabadságjogokért v Hungary No 37374/05 § 27, 14.4.2009 and Kenedi v Hungary No 31475/05 § 45, 26.5.2009.

14 Alasdair Roberts, "Structural Pluralism and the Right to Information" (2001) 51 University of Toronto Law Journal 243, 259.

15 Sebina, above $\mathrm{n} 7,67$.

16 Mason states that ' $[t]$ he two freedoms are often mentioned in the same breath, so to speak, as if they are so closely connected or intertwined that one [FOI] is part or counterpart of the other [Freedom of Expression]'. See The Hon. Sir Anthony Mason, 'The Relationship between Freedom of Expression and Freedom of Information' in Jack Beatson \& Yvonne Cripps (eds), Freedom of Expression and Freedom of Information (2000) 225, 225; Sebina, above $n$ 7. The term freedom of information used by Besley and other scholars to analyse the Chinese famine of 1959 and 1961 was synonymous with the idea of a free and independent press. Besley and other scholars observe that 'investigators have pointed to China's lack of democracy and of freedom of information (emphasised added) as reasons why it experienced a major famine between 1958 and 1961, with excess mortality figures ranging between 16.5 and 29.5 million'. See Timothy Besley et al, 'Mass Media and Political Accountability' in the World Bank (ed), The Right to Tell: The Role of Mass Media in Economic Development (2002) 45, 53.

17 Glasnost, a key term introduced by Gorbachev, could be translated as transparency, but 'the term lends itself to more than one interpretation' because it could 'mean something close to freedom of information and freedom of speech'. See Archie Brown, The Gorbachev Factor (1 ${ }^{\text {st }}$ ed, 1997) 125. Gorbachev said in December 1984 that: '[a]n inalienable component of socialist democracy is glasnost'. See Mikhail Gorbachev, Selected Comments of Gorbachev $\left(1^{\text {st }}\right.$ ed, 1987) 23. After Gorbachev became the national leader in 1985 , he conducted transparency reform that allowed all information concerning state and government activities to be disclosed and debated in public. See Hua Li, 'Political Publicity: Significance, Pitfalls and Inspiration' (in Chinese) (2004) 8 Nanjing Social Science 44, 45. 
China, ${ }^{18}$ thus necessitating effective strategies to lessen the concern about the incompatibility of FOI with China's political system. Gorbachev's glasnost reform agenda was seen in China as being partly responsible for the ultimate breakdown of the Soviet Union. This situation was likely in the eyes of some Chinese authorities to strengthen the incompatibility between transparency and the broad political system in China. ${ }^{19}$ Chen argues that the Glasnost agenda was actually a factor contributing to the postponement of transparency reform in China, which was proposed at the $13^{\text {th }}$ National Congress of the CPC (NCCPC) in $1987 .{ }^{20}$ The breakdown of the Soviet Union was also the key reason why a retrospective TV program, titled 'You Have the Right to Know' did not pass the censoring process in 2002, only five years before the adoption of FOI legislation in China. ${ }^{21}$ An overall negative impression of Gorbachev's glasnost reform highlighted political sensitivity to FOI and freedom of expression linkage, especially in the early stage of developing an FOI policy.

\subsubsection{Strategies to lessen the incompatibility concern}

Chinese reformers developed effective strategies to lessen the concern over incompatibility of FOI with China's political system. The longstanding central political commitment to developing democracy since the late 1970 s encouraged reformers to conduct FOI reform. Some support for transparency from Marx, Lenin and Mao gave Chinese reformers further confidence to introduce transparency reform

18 Huanchang Chen, Setting up a Correct Role for Audits to Promote New Development of Audit Work (in Chinese) (2003) The National Audit Office <http://www.audit.gov.cn/n1057/n1072/n13 42/14784.html $>$ at 5 May 2008.

19 Zongliang Huang, 'Learning Experiences and Lessons from Ruling Parties in Foreign Countries to Strengthen the Building of Governance Capabilities of the CPC' (in Chinese) (2004) 4 Journal of the Party School of Tianjin Committee of the CPC 41,43; Dianchao Cui, 'The Russian Reform Fell into the Trap of Democratisation' (in Chinese) (2000) 1 China National Conditions and Strength 34, 34; Tieying Li, 'A Speech at the Spring Festival Forum Held by the Contemporary China Institute' (in Chinese) (2002) 2 Contemporary China History Studies 4, 5.

20 Chen, above $\mathrm{n} 18$.

21 Zhou recalled that in 2002 he was invited to assist the editors of China Central Television in reflecting back on their past five years of work for a famous program - News Probe - to celebrate their achievement. They intended to use the title, 'You Have the Right to Know', for the retrospective program, but one leader cancelled the program without hesitation after he had only glanced at this seemingly sensitive title, and asked one of the editors that 'do you know the reason of the former Soviet Union's collapse?' As a result, the program did not pass the censoring process. See Zhou, above n 1. 
during the process of democratisation. In addition, Chinese reformers found support for FOI reform from the sovereignty of the people as set out in the Constitution 1982. ${ }^{22}$ Thus, the development of socialist democracy, at least from an ideological or theoretical basis, made it possible for the acceptance of the pull aspect of FOI in China. ${ }^{23}$ More importantly, the thesis argues that the political sensitivity of FOI was lessened after Chinese reformers opted to temporarily disconnect FOI from freedom of expression in the initial stage of FOI reform. This increased the possibility for the acceptance of a particular type of FOI that emphasises information flow in China.

\section{A constant political commitment to democracy: precondition for FOI reform}

In the last three decades, Chinese political leaders' advocacy of democracy that emphases local elections and political participation presented an opportunity for China to accept FOI, a type of information flow, as part of its long term democratisation program. Chinese political leaders have absorbed a significant lesson from the destructive impact of the Cultural Revolution (1966-1976), namely the necessity to build democracy gradually. ${ }^{24}$ The leaders, including Deng, ${ }^{25} \mathrm{Jiang}^{26}$ and $\mathrm{Hu},{ }^{27}$ have consistently stated that democracy is the goal of the CPC. The reason for taking democracy as the goal of the CPC is the recognition that '[w]ithout democracy there could be no socialism, much less socialist modernisation'. ${ }^{28}$ Democracy has been considered by Chinese leaders as a panacea for a wide range of social and political challenges, including social unrest and a broadening income gap arising

22 Hanhua Zhou, Academic Draft of FOI Regulations (in Chinese) (1 $1^{\text {st }}$ ed, 2003) 22-3; Explanation Memorandum, The Draft of FOI Regulations 2002 (China) 14-15.

23 Lianhe Ju and Yafan Wang, 'Four Factors of the Operation System of Current China's Openness in Government Affairs' (in Chinese) (2005) 6 Journal of Northeast Normal University 43, 43.

24 Xiaoping Deng, Selected Works of Xiaoping Deng (Volume II) (in Chinese) (2 ${ }^{\text {nd }}$ ed, 1994) 168.

25 Ibid 285. Deng stated in 1989 that '[d]emoracy is our goal'.

26 Jiang stated in 1997 that '[i]t is our Party's persistent goal to develop socialist democracy'. See Zemin Jiang, 'Hold High the Great Banner of Deng Xiaoping Theory for an All-round Advancement of the Cause of Building Socialism with Chinese Characteristics to the $21^{\text {st }}$ Century' (in Chinese) (Speech delivered at the $15^{\text {th }}$ National Congress of the CPC, Beijing, 12 September 1997).

27 President $\mathrm{Hu}$ stressed in 2007 that 'to develop socialist democracy is the unswerving goal of the CPC'. See Jintao Hu, Speech delivered at the Party School of the CPC Central Committee. See http://news.xinhuanet.com/politics/2007-06/25/content 6290208.htm.

28 Deng, above n 24, 158; Jiang, above n 26; Hu, above $n 27$. 
from the process of modernisation. ${ }^{29}$ The CPC recognises that democracy is the lifeblood of the socialism and the state. ${ }^{30}$ Thus, the development of socialist democracy has been a central task for the CPC since the end of $1970 \mathrm{~s} .{ }^{31}$ Chinese political leaders' commitment to developing democracy has generated a favourable consideration of transparency reform. Political leaders have not considered that socialism is alien to democracy. ${ }^{32}$

Furthermore, the central endorsement of deliberative democracy as one form of socialist democracy ${ }^{33}$ has arguably made FOI less incompatible with the Chinese political system. FOI is critical in developing deliberative democracy that has emerged in the last two decades to allow citizens to participate in and deliberate on public problems and solutions. ${ }^{34}$ Information disclosure is a precondition for public

29 Fred Bergsten et al, China's Rise · Challenges and Opportunities ( $1^{\text {st }}$ ed, 2008) 58.

30 Jintao Hu, 'Hold High the Great Banner of Socialism with Chinese Characteristics and Strive for New Victories in Building a Moderately Prosperous Society in All Respects' (in Chinese) (Speech delivered at the $17^{\text {th }}$ National Congress of the CPC, Beijing, 24 October 2007); Keping Yu, 'Democracy Is the Lifeblood of the People's Republic of China' (in Chinese) (2007) 22 People Forum 6, 6-8.

31 There is some doubt about China's democratisation reform agenda. See Junning Liu, 'China's Reform: Approaching a Dead End' (2007) 3 China Security 90-102; James Mann, The China Fantasy: Why Capitaltsm Will Not Bring Democracy to China $\left(1^{\text {st }}\right.$ ed, 2008) 19; Jean Grugel, Democratisation: A Critical Introduction (1 ${ }^{\text {st }}$ ed, 2002) 224-6; Randall Peerenboom, China Modernizes: Threats to the West or Model for the Rest? (1 $1^{\text {st }}$ ed, 2007) 280.

32 Premier Wen said in 2007 that: '[w]e never view socialism and democracy as something that are mutually exclusive. As a matter of fact, we see a high degree of democracy and a well developed legal system as inherent requirements of socialism and a key important feature of a mature socialist system'. See Jiabao Wen, 'Our Historical Tasks at the Primary Stage of Socialism and Several Issues concerning China's Foreign Policy' People's Daily (in Chinese) (Beijing) 27 February 2007, 2.

33 Opinions on Strengthening the Work of the Chinese People's Political Consultative Conference No 5 [2006] of the CPC Central Committee. The Chinese People's Political Consultative Conference, a fundamental political structure in China, may not be regarded as a form of deliberative democracy. However, in China, this is considered as a key part of deliberative democracy, but not all. Other universal accepted forms of deliberative democracy, such as consensus conferences and consulting meetings have been held in China at the grassroots level. See Baogang He, 'The Theory and Practice of Chinese Grassroots Governance: Five Models' (2003) 4 Japanese Journal of Political Science 293, 303-5; Baogang He, 'Deliberative Democracy and Democratisation' (in Chinese) (2007) 4 China Institute of Theory on the Chinese People's Political Consultative Conference 34, 34-5; Bergsten et al, above n 29, 63.

34 Many have contributed to the notion of deliberative democracy, such as Joseph Bessette, Jon Elster, Jon Elster, Jürgen Habermas, David Held, Joshua Cohen, John Rawls, Amy Gutmann and John Dryzek. Elster argues that the notion of deliberative democracy 'includes collective decision making with the participation of all who will be affected by the decision or their representatives ... [and] decision maing by means of arguments offered by and to participants who 
participation in decision-making, which lies at the core of deliberative democracy. ${ }^{35}$ Compared with liberal democracy, deliberative democracy is more compatible with the current Chinese political system. ${ }^{36}$ This is the reason why Chinese political leaders have laid great stress on scientific and democratic decision-making to develop socialist democracy in recent years (see 4.3.1). Yu argues that democratic decisionmaking actually includes elements of deliberative democracy. ${ }^{37}$ More importantly, in February 2006 the CPC Central Committee explicitly showed support for deliberative democracy in its policy document, titled 'Opinions on Strengthening the Work of the Chinese People's Political Consultative Conference'. ${ }^{38}$ The document states that electoral and deliberative democracies are two forms of socialist democracy. ${ }^{39}$ In 2007, the White Paper on China's Political Party System further claimed that '[o]ne major feature of China's socialist democracy is the combination of democratic election and democratic consultation ... [and this] has extended the width and depth of socialist democracy, 40

\section{Ideological support for FOI reform from leading Marxists}

Some support for transparency from Marx, Lenin and Mao may have influenced the acceptance of a type of FOI that emphasises information flow between the government and citizens to develop socialist democracy. Marx stressed the importance of openness when he discussed the experiences of the Paris Commune. ${ }^{41}$ He said that 'the Commune did not pretend to infallibility. ... It published its doings

are committed to the values of rationality and impartiality'. See Jon Elster, Deliberative Democracy $\left(1^{\text {st }}\right.$ ed, 1998) 8.

35 Youxing Lang, 'Deliberative Democracy and Local Experiences in China: A Case Study on the "Democratic Talkfest" in Zhejiang Province' (in Chinese) (2005) 1 Zhejiang Social Science 33, 37; Rhys Stubbs, 'FOI and Democracy in Australia and Beyond' (2008) 4 Australian Journal of Political Science 667, 681.

36 He, above n 33, 34-5.

37 Jian Yan, Make Democracy Benefit China: Dialogue with Professor Keping $Y u$ (in Chinese) $\left(1^{\text {st }}\right.$ ed, 2009) Preface.

38 Opinions on Strengthening the Work of the Chinese People's Political Consultative Conference, above $\mathrm{n} 33$.

39 Ibid.

40 The State Council Information Office, The White Paper on China's Political Party System (15 November 2007, Beijing).

41 Karl Marx and Frederick Engels, Marx and Engels Collected Works (Volume 22) (1 ${ }^{\text {st }}$ ed, 1986) 340. 
and sayings; it initiated the public into all its shortcomings' ${ }^{42}$ This indicates that Marx advocated transparency. ${ }^{43}$ Lenin recognised that transparency was a precondition for socialist democracy. ${ }^{44} \mathrm{He}$ stated that the new Soviet authority 'concealed nothing, it had no secrets. ... It was an authority open to all, it carried out all its functions before the eyes of the masses, was accessible to the masses ... ${ }^{45}$

The Mass Line, which refers to 'everything for the masses, reliance on the masses in everything, and from the masses, to the masses', ${ }^{46}$ has become a domestic political foundation for transparency reform in China. ${ }^{47}$ Both Marx and Lenin's support for transparency may have been considered disconnected with China's local conditions. The views of leading Chinese Marxists, including Chairman Mao and Premier Zhou, are more important and relevant. Mao relied on the Mass Line to support transparency. The Mass Line, a vital part of Maoism, has been considered by the CPC as its inexhaustible source of strength. ${ }^{48}$ Transparency or flow of information is inherent in the Mass Line as it is essential for achieving the goal of 'to the masses' ${ }^{49}$ In 1948, Mao called on government officials to change their secretive working styles to inform the public of land reform policies in order to gain their support and implement the policies. ${ }^{50}$

\section{Ibid.}

43 Jie Liu, The Right to Know and the FOI Act (in Chinese) (1 $\left.1^{\text {st }} \mathrm{ed}, 2005\right), 245$.

44 Lenin argued that '[e]veryone will probably agree that 'the broad democratic principle' presupposes the two following conditions: first, full publicity (emphasis added), and secondly, election to all offices. It would be absurd to speak of democracy without publicity, moreover, without a publicity that is not limited to the membership of the organisation. We call the German Socialist Party a democratic organisation because all its activities are carried out publicly; even its party congresses are held in public. But no one would call an organisation democratic that is hidden from everyone but its members by a veil of secrecy (emphasis added)'. See Vladimir Lenin, Lenin Collected Works (Volume 5) (1 $1^{\text {st }}$ ed, 1961) 477.

Vladimir Lenin, Lenin Collected Works (Volume 10) (1 ${ }^{\mathrm{st}}$ ed, 1962) 242.

46 Zedong Mao, Selected Works of Zedong Mao (Volume III) (in Chinese) ( $1^{\text {st }}$ ed, 1953) 899; Resolution on Certain Questions in the History of Our Party since the Founding of the People's Republic of China (1981).

47 Zhengqun Zhao, 'Discussion of Anti-Corruption through Openness in Government Affairs' (in Chinese) (2001) 6 Theory and Modernisation 51, 52.

48 Jiang, above $\mathrm{n} 26$.

49 Liu, above $\mathrm{n} 43$.

50 Mao argued that 'Our policy must be made known not only to the leaders and to the cadres but also to the broad masses (emphasis added). ... There are people in our leading organs in some places who think that it is enough for the leaders alone to know the Party's policies and that there 
Also for the purpose of implementing land reform policies, Enlai Zhou, the first premier of China, said that any decision or change concerning a policy, and any correct or wrong part of a policy, had to be disclosed to the masses in the appropriate time to gain their understanding and support. ${ }^{51}$ The Mass Line became the basis for the $13^{\text {th }}$ NCCPC in 1987 advocating transparency. ${ }^{52}$ This NCCPC called on leading agencies to improve the openness of their activities and let the people know about and discuss important matters in order to carry on the fine tradition of the Mass Line, 'from the masses and to the masses'. 53

Leading Marxists' support of transparency suggested that reformers would not make any serious political mistakes if they undertook transparency reform. However, the support of transparency from leading Marxists was only a necessary, rather than a sufficient, condition for the Chinese government to accept the role of transparency in developing socialist democracy. ${ }^{54}$ This suggests that further support, especially through the Constitution was also needed.

\section{The sovereignty of the people: constitutional support for FOI reform}

Chinese reformers found convincing evidence from the Constitution 1982 to reject the perceived incompatibility or mutual exclusivity between FOI and a MarxismLeninist political system. The reformers' original assertion that FOI reform was supported by the Constitution 1982 became more acceptable and gained more support after the central endorsement of full implementation of the Constitution in late 2002. In a December 2002 speech commemorating the $20^{\text {th }}$ anniversary of the adoption of

is no need to let the masses know them.... This is one of the basic reasons why some of our work cannot be done well. ... Subjectively, they too want everyone to take a hand in the work, but they do not let other people know what is to be done or how to do it. That being the case, how can everyone be expected to get moving and how can anything be done well?'. See Zedong Mao, Collected Works of Zedong Mao (Volume IV) (in Chinese) (2 ${ }^{\text {nd }}$ ed, 1991) 1318-19.

51 Enlai Zhou, Selected Works of Enlai Zhou (in Chinese) (1 $\left.1^{\text {st }} \mathrm{ed}, 1984\right) 301$.

52 Ziyang Zhao, 'Take Strides along the Road to Socialism with Chinese Characteristics' (in Chinese) (Speech delivered at the $13^{\text {th }}$ National Congress of the CPC, Beijing, 25 October 1987).

53 Ibid.

54 Even Mao, when reflecting on the drawbacks arising from the transparency policy for land reform in 1957, put forward a key principle to guide news reports in China, namely 'the news, old news or no news' (Xinwen, Jiuwen, Buwen) (see 3.1.3). See Zedong Mao, Selected Works of Zedong Mao on Journalism (in Chinese) $\left(1^{\text {st }}\right.$ ed, 1982) 193. 
the Constitution, $\mathrm{Hu}$ stated that 'implementation of the rule of law first and foremost requires fully enforcement of the Constitution' ${ }^{55}$ He reiterated this announcement in a speech at the $50^{\text {th }}$ anniversary of the National People's Congress (NPC), stating that 'ruling the state by the rule of law first needs ruling the state by the Constitution, [and] administration by law first requires administration by the Constitution, ${ }^{56}$

Chinese reformers rationalised FOI primarily from the sovereignty of the people set out in the Constitution $1982 .{ }^{57}$ The sovereignty of the people appears in many countries' constitutions. China's Constitution 1982 is no exception. The Constitution states that all the power in China belongs to the people. ${ }^{58}$ This means that the people are the masters of the state, which is the essence of China's socialist democracy. ${ }^{59} \mathrm{~A}$ right to know, albeit only implied in the Constitution $1982,{ }^{60}$ is a right to aid the people to exercise the masters' role. $^{61}$

Chinese reformers viewed FOI as a prerequisite for the exercise of several key constitutional rights related to the sovereignty of the people. ${ }^{62}$ It has been recognised that the people's constitutional rights are not comprehensively protected without an FOI mechanism. ${ }^{63}$ As masters of China, the people can manage the state, the economy, the culture and other public affairs through a multitude of means and forms. ${ }^{64}$ Such management cannot function well without information availability. ${ }^{65}$

55 Jintao Hu, 'Fully Implementing the Constitution to Provide Legal Guarantees for Building a WellOff Society in All Aspects' (in Chinese) (Speech delivered at the $20^{\text {th }}$ Anniversary of the Adoption of the Constitution, Beijing, 4 December 2002).

56 Jintao $\mathrm{Hu}$, Speech delivered at the $50^{\text {th }}$ Anniversary of the National People's Congress, Beijing, 15 September 2004.

57 In China, the current Constitution was adopted by the Fifth National People's Congress on 4 December 1982. There are three previous versions of Constitution, including those of 1954, 1975 and 1978, which were repealed. The latest Constitution was revised in 1988, 1993, 1999 and 2004. The Constitution 1982 (China) Art 1.

Hu, above $\mathrm{n} 30$.

Zhou, above n 22, 23.

Zhou, above n 22; Explanation Memorandum, above $\mathbf{n} 22$.

Ibid.

Explanation Memorandum, above $\mathrm{n} 22,15$.

The Constitution 1982 (China) Art 2.

Explanation Memorandum, above n 22, 15. 
Chinese reformers also saw FOI as a precondition for the exercise of the right to supervise. ${ }^{66}$ The Constitution 1982 requires all government agencies and officials to rely on the support of the people, keep in close touch with them, heed their opinions and suggestions, accept their supervision, and work hard to serve them. ${ }^{67}$ However, the people cannot supervise government agencies and officials without knowledge concerning the operation of government work. ${ }^{68}$

\section{The original disconnection of $\mathrm{FOI}$ with freedom of expression}

While Chinese reformers asserted that FOI is a mechanism for the eventual securing of a right to freedom of expression, ${ }^{69}$ they uncoupled FOI from freedom of expression at the initial stage of consideration. The Constitution 1982 empowers the people to criticise and make suggestions to any government agency or official, to make complaints and charges against, or exposure of, any government agency or official for violation of the law or dereliction of duty. ${ }^{70}$ To exercise this constitutional right, the people need a right to know. However, Chinese reformers recognised that reliance on the link between FOI and freedom of expression under the Constitution only encouraged more resistance to FOI reform, especially after the failure of glasnost reform in the former Soviet Union.

The temporary separation of FOI from freedom of expression is a prominent feature of FOI reform in China. This separation helped diminish the political sensitivity of FOI in China, and smoothed the way for FOI reform. Chinese reformers realised that it was inappropriate to couple FOI with the promotion of the right to freedom of expression due to the lack of Freedom of the Press Act and an authoritative interpretation of freedom of expression laid down in Article 35 of the Constitution. ${ }^{71}$ Yet this approach to FOI is contradictory to the dominant theme in the literature,

66 Ibid.

67 The Constitution 1982 (China) Art 27.

68 Hanhua Zhou, 'Open Government in China: Practice and Problems' in Ann Florini (ed), The Right to Know: Transparency for an Open World (2007) 92, 105.

69 Zhou, above n 22; Explanation Memorandum, above n 22; Liu, above n 43, 89.

70 The Constitution 1982 (China) Art 41.

71 Zhou, above n 22; Yunfan Zhou, 'Analysis of FOI Law-Making Activities in China' (in Chinese) (2005) 6 Journal of Jinan University 54, 56. 
which closely entwines FOI with freedom of expression or presents each as a mutually dependent limb of the same process. The uncoupling allowed the idea of FOI to be openly discussed in China, and created a precondition for reconnecting FOI with freedom of expression at a later stage of considering FOI legislation (see 4.3.2). This reconnection increased government receptivity to FOI in China.

\subsection{Grassroots democracy: an experiment in transparency}

FOI reform was needed to reinforce and extend openness experiments that have served China's incremental democratisation process for a long period. These experiments reduced the concern about incompatibility of FOI with China's political system. Grassroots democracy, a key part of socialist democracy in China, made it possible to experiment with the antecedents of FOI, including Openness in Village Affairs (OVA) and OGA at the township level. This gradually improved information flow from the government to the public, thereby increasing the capacity to accept FOI. Thus, contrary to the perception that FOI reform gained full force overnight with little warning and few antecedents, the reform was the outcome of a gradual transformation toward a pull aspect of FOI (Figure 4).

\section{Figure 4 The role of democratisation in improving information flow}

The supply side/government

\begin{tabular}{|c|c|c|c|}
\hline \multicolumn{2}{|c|}{ Grasstoots democracy } & \multicolumn{2}{|c|}{ Socialist democracy } \\
\hline OVA & $\begin{array}{l}\text { OGA at township } \\
\text { gowernments }\end{array}$ & $\begin{array}{l}\text { OGA at all levels of } \\
\text { government }\end{array}$ & $\mathrm{FOI}$ \\
\hline $1980 \mathrm{~s}$ & 2000 & 2005 & 2007 \\
\hline $\begin{array}{c}\text { Push|aspect } \\
\text { accepted }\end{array}$ & $\begin{array}{l}\text { Push aspect } \\
\text { accepted }\end{array}$ & $\begin{array}{l}\text { Push|aspect } \\
\text { accepted }\end{array}$ & $\begin{array}{l}\text { Pull aspect } \\
\text { accepted }\end{array}$ \\
\hline
\end{tabular}

The demand side/citizens 


\subsubsection{Openness in Village Affairs: safeguarding grassroots democracy}

Grassroots democracy enabled OVA, the first openness experiment in China, ${ }^{72}$ to be developed. OVA was a category of information flow that prepared the ground for another more significant push aspect of information flow, OGA, to be experimented with. Grassroots democracy at the village level has been promoted as a key political reform program for China to gradually develop socialist democracy since the early $1980 \mathrm{~s}^{73}$ It is the "priority and breakthrough point ${ }^{74}$ of China's democratisation, and 'the most direct and broadest practice of democracy, ${ }^{, 75}$ in China to date. Grassroots democracy was practiced in China through the establishment of a self-government system with an emphasis on rural villagers' committees ${ }^{76}$ to fill the gap in administering villages after the people's communes ceased in the late $1970 \mathrm{~s} .{ }^{77}$ The Constitution 1982 first supported the establishment of a villagers' autonomy system. ${ }^{78}$ This system was further standardised by the Organic Law of the Villagers' Committees (for trial) 1987. After 10 years' trial, the Law was replaced by the Organic Law of the Villagers' Committees 1998, which signalled the institutionalisation of grassroots democracy in rural areas.

Democratic supervision, a key democratic means to develop grassroots democracy, ${ }^{79}$ made it possible to experiment with OVA because it was originally recognised as a

72 Yuguang Shang, 'Discussion of the System of Administrative Openness' (in Chinese) (2005) 24 The Epochal Tide 48, 48.

73 The CPC Central Committee, Communique of the Second Plenary Session of the $17^{\text {th }}$ CPC Central Committee (2008).

74 Keping Yu, 'Emancipation of Mind and Political Progress' (in Chinese) Beijing Daily (Beijing) 17 September 2007, 18.

75 The State Council Information Office, The White Paper on the Building of Political Democracy in China (19 October 2005, Beijing).

76 Ibid. The first villagers' committee was established in Guangxi in February 1980. Fan Li, 'The Practice of Democratic Elections in China' (in Chinese) (2005) 9 China Reform 15, 15.

77 Jamie Horsley, 'Toward a More Open China?' in Ann Florini (ed), The Right to Know: Transparency for an Open World (2007) 54, 58-9. The people's commune refers to a collective economic and grassroots regime organisation, which was established based on advanced agricultural production cooperatives in 1958. In general, there was one commune per township.

78 The Constitution 1982 (China) Art 111.

79 Grassroots democracy has been expanded in China through the establishment of four democratic means: democratic election, decision-making, management and supervision. See Jiang, above $\mathrm{n}$ 26; The Organic Law of the Villagers' Committee 1998 (China) Art 2. 
tool for overseeing village officials. ${ }^{80}$ In the early 1980 s, some villages began to experiment with OVA during the establishment of villagers' autonomy system. ${ }^{81}$ These openness practices were first confirmed by the Organic Law of the Villagers' Committees (for trial) 1987, which required villagers' committees to periodically disclose income and expenditure on public affairs and public utilities. ${ }^{82}$ Overall implementation of OVA achieved support from the central government in 1994 after the issue of the Notice on Enhancing the Construction of Grassroots Organisations in the Rural Areas. ${ }^{83}$ This Notice broadened previous openness practices, requiring all villagers' committees to periodically disclose information of mutual interest of villagers. ${ }^{84}$ The work of OVA was expanded in 1998 after the issue of the Notice on Comprehensively Implementing Openness in Village Affairs and Democratic Management, ${ }^{85}$ which formed the basis of openness requirements under the Organic Law of the Villagers' Committees 1998. Since the adoption of this Law, OVA has been formally allowed by the law and developed in the whole country. ${ }^{86}$ To strengthen OVA, the central government circulated another notice in $2004 .{ }^{87}$ With strong support from the central government, the work of OVA is now widely implemented in China. ${ }^{88}$ OVA became crucial for OGA at the township level.

80 The Ministry of Civil Affairs, The Main Achievements in Villagers' Autonomy (in Chinese) <http://www1.mca.gov.cn/artical/content/WCM_YWJS/20031224145129.htm> at 2 April 2008. The White Paper on the Building of Political Democracy in China states that ' $[\mathrm{t}]$ he villagers supervise the committee's work and the conduct of the village cadres through making village affairs open'. See The State Council Information Office, above n 75. The Ministry of Civil Affairs, above $\mathbf{n} 80$.

82 The Organic Law of the Villagers' Committees (for trial) 1987 (China) Art 17.

83 The Notice on Enhancing the Construction of Grassroots Organisations in the Rural Areas No 10 [1994] of the General Office of the CPC Central Committee.

84 Ibid.

85 The Notice on Comprehensively Implementing Openness in Village Affairs and Democratic Management No 9 [1998] of the General Office of the CPC Central Committee.

86 Article 22 under this Law requires villagers' committees to disclose the following matters without delay: matters decided on through discussion by villagers' assemblies as provided for in Article 19 of this Law, and implementation of the decisions; plans for implementing the state policy for family planning; handing out of relief funds and goods; collection of charges for the supply of water and electricity, and other matters that involve villagers' interests and concerns. In terms of financial affairs, this Law mandates its disclosure every six months at least.

87 Suggestions on Fully Establishing and Enhancing Openness in Village Affairs and Democratic Management No 17 [2004] of the General Office of the CPC Central Committee.

88 By the end of 2003 , more than 95 percent villages had fully implemented the policy of openness in village affairs in China. See Jingyong Zhang et al, The 'Sunshine Project' Benefits the Masses. 


\subsubsection{Openness in Government Affairs at the township level: expanding grassroots democracy}

Along with OVA, OGA at township governments has been considered as an important measure to expand grassroots democracy. The acceptance of openness experiments within government was a significant breakthrough in China, directly assisting information flow from the government to society and ameliorating the Chinese information environment surrounding FOI. OGA at the primary level was first supported by the central government in 1997 as a tool for expanding grassroots democracy. ${ }^{89}$ At the $15^{\text {th }}$ NCCPC, the national CPC congress, the political report stated that ${ }^{6}[\mathrm{t}]$ he grassroots organs of power and self-governing mass organisations in both urban and rural areas should ... keep the public informed of their political activities and financial affairs ... ${ }^{90}$ The Chinese government considered that OGA at the primary level could aid in establishing closer ties between the government and the people, and implement the central policies. ${ }^{91}$ The political report of the $17^{\text {th }}$ NCCPC reiterated that OGA at the township level could bring about 'effective connection and beneficial interaction between government administration and primary-level selfgovernance'.92

However, OGA at the primary level was not strongly supported by the central government until late 2000 after the issue of the Notice on Promoting Openness in Government Affairs around All Government Agencies at the Township Level. ${ }^{93}$ In 1998, the Notice on Comprehensively Implementing Openness in Village Affairs and Democratic Management encouraged, but did not require government agencies at the

China Actively Promotes Openness in the Process of Administrative Affairs (in Chinese) (2003) Xinhua Net <http://news.xinhuanet.com/newscenter/2003-12/30/content_1254392.htm> at 10 February 2008.

89 Jiang, above n 26.

90 Ibid.

91 The Notice on Promoting Openness in Government Affairs around All Government Agencies at the Township Level No 25 [2000] of the General Office of the CPC Central Committee.

$92 \mathrm{Hu}$, above $\mathrm{n} 30$.

93 The Notice on Promoting Openness in Government Affairs around All Government Agencies at the Township Level, above $\mathrm{n} 91$. 
township level to practice OGA during the period of implementing OVA. ${ }^{94}$ However, the Notice on Promoting Openness in Government Affairs around All Government Agencies at the Township Level branded OGA as important to extend the scope of democracy at the grassroots level, requiring all township government agencies to focus on disclosure of the practical problems that people were most concerned about and that affected the vital interests of the people. ${ }^{95}$

\subsection{Socialist democracy: developing by Openness in Government Affairs at all levels}

OGA at all levels of government was built upon OGA at the primary level. The promotion of OGA at all levels further improved information flow from the government to society, thus ameliorating the Chinese information environment and increasing the capacity to accept FOI. During the period OGA operated at the township level, some government agencies at and above the county level started to disclose information concerning their administrative affairs (see 7.1.3). ${ }^{96}$ The central government gained experiences from these practices. It issued the Notice on Further Promoting Openness in Government Affairs in 2005, deciding to expand these openness practices to government agencies at all levels. ${ }^{97}$ In this Notice, the central government recognised that OGA was necessary to a broader socialist democracy, ${ }^{98}$ not only to grassroots democracy. This is because OGA has been regarded as a prerequisite for developments in democratic means, such as democratic decisionmaking, management and supervision, and protection of key democratic rights, such as the rights to know, participate and supervise (see 4.3.1 and 4.3.2). The promotion of OGA from this political perspective directly brought about the acceptance of the

94 The Notice on Comprehensively Implementing Openness in Village Affairs and Democratic Management, above n 85.

95 The Notice on Promoting Openness in Government Affairs around All Government Agencies at the Township Level, above $\mathrm{n} 91$.

96 The General Office of the Central Commission for Discipline Inspection, Openness in Government Affairs ( ${ }^{\text {st }}$ ed, 2004) 11.

97 The Notice on Further Promoting Openness in Government Affairs No 12 [2005] of the General Office of the CPC Central Committee.

98 Ibid. 
access mechanism in China because the access mechanism is a tool for implementing all these democratic means and rights.

\subsubsection{Openness in Government Affairs: precondition for developments in democratic means}

Democratic election, decision-making, management and supervision have been recognised as four major means of developing China's socialist democracy since $1997 .{ }^{99}$ The four democratic means, the last three in particular, laid the foundation for extension of OGA to higher levels of government.

OGA was not considered as a tool for enhancing election processes. The processes of democratic election were promoted in China earlier than those of democratic decision-making, management and supervision. However, they were largely limited to the grassroots level, and had little opportunity to be upgraded to a higher level in the immediate future. Direct elections at the grassroots level were permitted under the Organic Law of the Villagers' Committee 1998 and the Organic Law of the Urban Residents Committees 1989, ${ }^{100}$ and established in China gradually. ${ }^{101}$ However, direct elections are not allowed for governments at and above the township level, although some local governments have experimented with direct elections in recent years. ${ }^{102}$ These experiments cannot be expanded and promoted to a higher level in China at present ${ }^{103}$ as they violate the Constitution $1982 .{ }^{104}$ Indeed, the Standing Committee of

99 Jiang, above n 26; Zemin Jiang, 'Build a Well-off Society in an All-Round Way and Create a New Situation in Building Socialism with Chinese Characteristics' (in Chinese) (Speech delivered at the $16^{\text {th }}$ National Congress of the CPC, Beijing, 8 November 2002); Hu, above $n 30$.

100 The Ministry of Civil Affairs, above $\mathrm{n}$ 80. The Organic Law of the Villagers' Committee 1998 (China) Art 11; The Organic Law of the Urban Residents Committees 1989 (China) Art 8; The Trade Union Law 1992 (China) Art 9.

101 According to the State Council Information Office, '[b]y the end of 2004, some 644,000 villagers' committees had been established throughout the country, with most of the provinces, autonomous regions and municipalities directly under the central government having elected their fifth or sixth committees'. See The State Council Information Office, above n 75.

102 The first trial was in two towns in Sichuan Province in 1998. See Yu Cao, 'The Gradual Trend toward Grassroots Democracy' (in Chinese) (2005) 9 People Forum 34, 35. In 2004, direct elections were conducted among seven township governments in Shipin County of Yunan Province. See Yimin Chen, 'Grassroots Democratisation and Democracy at the Grassroots Level' (in Chinese) (2007) 9 China Reform 27, 27.

103 Chen, above n 102. 
the NPC, China's Parliament, noted this unconstitutional event and called for the cessation of the experiment in 2001, although the impact of this call was limited. ${ }^{105}$

Thus, OGA was mainly considered as a tool for improving democratic decisionmaking, management and supervision. The political report of the $15^{\text {th }} \mathrm{NCCPC}$ in 1997 recognised the need for the exercise of democratic decision-making, management and supervision to be assisted by openness. ${ }^{106} \mathrm{~A}$ goal for promoting OGA at the primary level was the implementation of the systems of democratic decision-making, management and supervision. ${ }^{107}$

Openness was originally recognised as a tool for democratic supervision. ${ }^{108}$ The project of Openness in Two Areas and Supervision by the Public was initiated to encourage the public to supervise government officials (see 7.1.1). ${ }^{109}$ The Chinese government in the Notice on Comprehensively Implementing Openness in Village Affairs and Democratic Management called for an effective use of OVA to improve supervision of village officials elected by villagers. ${ }^{110}$ Chinese anti-corruption agencies endeavoured to promote OGA to enhance democratic supervision since the late 1980s. ${ }^{111}$ Thus, openness was regarded as an indispensable tool for developing democratic supervision in China.

The central political endorsement of scientific and democratic decision-making generated more favourable consideration of OGA at higher levels of government. The promotion of scientific and democratic decision-making became one of the three

104 Article 101 of the Constitution 1982 confers on local people's congresses at their respective levels, rather than the citizens to elect and recall governors and deputy governors, mayors and deputy mayors, or heads and deputy heads of counties, districts, townships and towns.

105 Weimin Shi, 'Many a Little Makes a Mickle - An Overview of the Building of Grassroots Democracy in China from 2000 to 2005' (in Chinese) (2005) 9 China Reform 15, 18. Chen, above n 102.

106 Jiang, above $\mathrm{n} 26$.

107 The Notice on Promoting Openness in Government Affairs around All Government Agencies at the Township Level, above $\mathrm{n} 91$.

108 The Ministry of Civil Affairs, above n 80.

109 The General Office of the Central Commission for Discipline Inspection, above $\mathbf{n} 96,6$.

110 The Notice on Comprehensively Implementing Openness in Village Affairs and Democratic Management, above $\mathbf{n} 85$.

111 The General Office of the Central Commission for Discipline Inspection, above $\mathbf{n} 96$. 
overarching tasks in the Hu-Wen administration after 2003. ${ }^{112}$ The Chinese government recognised that 'correct decision-making is an important prerequisite for success in all work'. ${ }^{113}$ It promoted democratic decision-making by increasing public participation in government legislation and by establishing many systems, such as OGA, expert consultation and appraisal, and public hearing. ${ }^{114}$

The focus on democratic decision-making necessitated a type of information flow like OGA. ${ }^{115}$ The political report of the $16^{\text {th }}$ NCCPC called for improving the decision-making mechanisms, requiring all decision-making agencies to establish a system of keeping the public informed to prevent arbitrary decision-making. ${ }^{116}$ Transparency was regarded as a key part of administrative decision-making in the Implementation Outline for pushing forward Administration by Law in an All-Round Way issued in 2004. ${ }^{117}$ The State Council adopted its new Working Rules in 2008, requiring it to directly hear the opinions and suggestions of grassroots people for important decisions. ${ }^{118}$ This is the first time that the State Council listed the majority of people in political life. It is likely to help develop the deliberative politics in China, assuring a successful future for FOI.

\subsubsection{Openness in Government Affairs: safeguarding key democratic rights}

In recent years, OGA has been regarded by Chinese reformers as an important tool for safeguarding four democratic rights, such as the right to know, participate,

\footnotetext{
112 Jiabao Wen, 'Pushing forward Administration by Law in an All-Round Way to Build a Government under the Rule of Law' (in Chinese) (Speech delivered at the National Picturephone Conference on the Work of Law-Based Administration, Beijing, 28 June 2004). The other two major tasks are law-based administration and administrative supervision. The Hu-Wen Administration is a name given to the current Party leader Jintao Hu and Premier Jiabao Wen.

113 Jiang, above $n 99$.

114 The State Council Information Office, above $\mathbf{n} 75$.

115 Jiang, above n 99; The State Council Information Office, above n 75.

116 Ibid.

117 The Implementation Outline for Pushing Forward Administration by Law in an All-Round Way No 10 [2004] of the General Office of the State Council.

118 Working Rules of the State Council No 14 [2008] of the State Council.
} 
freedom of expression and supervise. ${ }^{119}$ These four democratic rights, mainly derived from the preceding four democratic means, have been used to develop socialist democracy. The connection of OGA with the right to know indicates that the central government has become receptive to the pull aspect of FOI. The Chinese government first recognised the role of OGA in safeguarding key democratic rights in 2006 under China's $11^{\text {th }}$ Five-Year Plan for National Economy and Social Development. ${ }^{120}$ This was reiterated in 2006 under the Resolution on Major Issues regarding the Building of a Harmonious Socialist Society. ${ }^{121}$

\section{The connection between $O G A$ and the right to know}

Previously, OGA was conducted in China without a tight connection to the right to know. This resulted in the predominant focus on proactive disclosure by government agencies. Since 2006, Chinese political leaders have shown strong support for promoting access to information so as to deepen transparency reform. ${ }^{122}$ This support benefited the acceptance of the access mechanism and the development of the right to know in China.

\section{The connection between $O G A$ and the right of participation}

Chinese political leaders have recognised OGA as a measure to secure the right of participation. In recent years, they have encouraged the public to participate in political affairs in an orderly way. The political report of the $16^{\text {th }}$ NCCPC stated that it was essential to 'expand citizens participation in political affairs in an orderly way, and [to] ensure that the people go in for democratic elections and decision-making, exercise democratic management and supervision according to law ... ${ }^{, 23}$ This view

119 The 11 Five-Year Plan for National Economy and Social Development (2006) Xinhua Net $<$ http://news.xinhuanet.com/misc/2006-03/16/content_4309517_20.htm > at 7 May 2008.

120 Ibid.

121 The Resolution on Major Issues regarding the Building of a Harmonious Socialist Sociery No 19 [2006] of the Central Committee of the CPC.

122 The 11 Five-Year Plan for National Economy and Social Development, above n 119.

123 Jiang, above $\mathrm{n} 99$. 
was reiterated by the CPC in $2004 .{ }^{124}$ The political report of the $17^{\text {th }}$ NCCPC also called for the expansion of citizens' orderly participation in political affairs at each level and in every field. ${ }^{125}$

The work of OGA in China was developed to expand citizens' orderly participation in political affairs. The White Paper on the Building of Political Democracy in China states that ' $[\mathrm{t}]$ he Chinese government requires its subordinate departments at all levels to make their administrative affairs public as far as possible, so as to enhance the transparency of government work and guarantee the people's right to ... participate in ... the work of the government' ${ }^{126}$ The focus on public participation, together with democratic decision-making, indicates that the Chinese government has accepted some elements of deliberative democracy where citizens are allowed to engage in decision-making about important issues. In early 2006, Chinese political leaders endorsed deliberative democracy. ${ }^{127}$ This served as a catalyst for a favourable consideration of OGA at a national level.

\section{The connection between $O G A$ and the right to freedom of expression}

OGA has been regarded by Chinese political leaders as a key tool for guaranteeing freedom of expression, but this link has only been formally expressed by the central government since $2006 .{ }^{128}$ Such a link indeed improved the central government's receptivity to FOI, thereby smoothing the way for the passage of FOI legislation. Chinese reformers initially considered that it was unsuitable for China to connect OGA with the safeguard of the right to freedom of expression. ${ }^{129}$ Thus, at the beginning, the role of OGA in promoting the right to freedom of expression was

\footnotetext{
124 The Decision of the CPC Central Committee on Strengthening the Building of the Party's Ruling Capability No 18 [2004] of the Central Committee of the CPC.

$125 \mathrm{Hu}$, above $\mathrm{n} 30$.

126 The State Council Information Office, above $\mathbf{n} 75$.

127 See above $\mathrm{n} 33$ and the accompanying text.

128 The 11 Five-Year Plan for National Economy and Social Development, above n 119; The Resolution on Major Issues regarding the Building of a Harmonious Socialist Society, above n 121.

129 Zhou, above n 22.
} 
ignored. On many occasions, Chinese reformers only addressed the role of OGA in promoting the right to know, participate and supervise. ${ }^{130}$

Chinese political leaders have addressed freedom of expression in recent years. The political report of the $17^{\text {th }} \mathrm{NCCPC}$ recognised the necessity to 'carry out democratic election, decision-making, management and supervision in accordance with the law to guarantee the people's rights to know, to participate, to express, and to supervise' ${ }^{131}$ The central endorsement of freedom of expression has significantly lessened the political sensitivity and incompatibility of FOI, which has increased China's capacity to accept the policy instrument of FOI. It has also helped Chinese reformers abandon their original assertion that FOI reform in China should not be coupled with freedom of expression.

\section{The connection between $O G A$ and the right to supervise}

OGA has also been viewed as the protection of the right to supervise. This right, which plays a key role in promoting democratic supervision, is conferred by the Constitution 1982. Chinese political leaders have endeavoured to promote democratic supervision in order to guarantee the right to supervise under the Constitution since the 1980s. OGA has been considered as a tool for enhancing the exercise of this constitutional right.

\subsection{FOI legislation: institutionalising Openness in Government Affairs}

Compared with other countries, China's FOI Regulations were primarily utilised to institutionalise the widespread practices of OGA to serve its long term

\footnotetext{
130 The State Council Information Office, above n 75; Qiong Zhang, "The Legislative Affairs of the State Council Introduces FOI Regulations' (Press Release, 24 April 2007); Xueshan Yang, 'Subsidiary Report on Learning FOI Regulations' (Speech delivered at Conference on Learning FOI Regulations, Beijing, 19 May 2007).

$131 \mathrm{Hu}$, above n 30.
} 
democratisation initiatives. ${ }^{132}$ As such, the traditional argument of economic growth and anti-corruption efforts accounting for FOI reform in China should be, arguably, downplayed (see Chapter 6). The Notice on Further Promoting Openness in Government Affairs required the acceleration of the legislative process of OGA through the introduction of FOI Regulations. ${ }^{133}$ Yong He, the Deputy Secretary of the Central Commission for Discipline Inspection, argues that the adoption of FOI Regulations can institutionalise OGA, mandate and standardise the operation of OGA. ${ }^{134}$ Thus, FOI Regulations are the basic legislation in relation to OGA, and play a key role in gradually institutionalising OGA in China. ${ }^{135}$ The passage of the FOI Regulations signals that the work of OGA has been institutionalised. ${ }^{136}$

However, the FOI Regulations were not used to merely institutionalise the work of OGA; they were also used to legislate on an access mechanism. This was unprecedented in China because many government officials still considered adopting the access mechanism, the pull aspect of FOI, to be premature. ${ }^{137}$ Some asked: 'is it possible to only legislate on proactive disclosure, and postpone the institutionalisation of access to information to a later date ${ }^{9138}$ However, the impact of this lower level government's resistance was weak as the central government had become more receptive to the role that the pull aspect of FOI could play in China's long term democratisation process.

132 Yong Yin, 'New Thoughts on Trying FOI Cases' (in Chinese) (2007) 5 Shanghai Journal of Law 51, 52; Zhou, above n 22, 57.

133 The Notice on Further Promoting Openness in Government Affairs, above n 97.

134 Yong He, 'The Leading Group on National Openness in Government Affairs Answered the Questions from Journalists about the Notice on Further Promoting Openness in Government Affairs' (Press Release, 27 April 2005).

135 Yong He, 'The Speech of Yong He at the Seventh Meeting of the Leading Group on National Openness in Government Affairs' (Speech delivered at Beijing, 21 March 2007).

136 Yisheng Gan, 'Speech by Yisheng Gan at the Teleconference on Training in FOI Regulations' (Speech delivered at Beijing, 17 May 2007); Kangtai Cao and Qiong Zhang, The Primer on China's FOI Regulations (in Chinese) $\left(1^{\text {st }}\right.$ ed, 2008) 37.

${ }^{137}$ Hanhua Zhou, Speech delivered at Seminar on the Challenges and Possibilities for Government Information Disclosure, Beijing, 25 June 2008. See http://www.gongmeng.cn/sub r.php?zyj id=1

$138 \frac{774 .}{\text { Ibid. }}$ 
The central government has also called for the provision of legal guarantees for democracy in recent years. This increased the possibility of the adoption of FOI that is an indispensable part of socialist democracy. The political report of the $16^{\text {th }}$ NCCPC in 2002 announced that ' $[w]$ e must concentrate on institutional improvement and ensure that socialist democracy is institutionalised and standardised and has its procedures'. ${ }^{139}$ This was reiterated in the political report of the $17^{\text {th }}$ NCCPC in 2007. ${ }^{140}$ It has been recognised that OGA plays an indispensable role in promoting socialist democracy (see 4.3.1), and that it is necessary to institutionalise OGA through the introduction of FOI Regulations. ${ }^{141}$

\subsection{Conclusion}

This chapter argues that democratisation increased China's capacity to accept FOI, as it played a significant role in improving information flow in the secretive Chinese information environment. Concerns surrounding the incompatibility between FOI and China's political system necessitated a particular type of FOI that emphasises both the push and pull aspects of information flow. Furthermore, long periods of openness experiments, such as OVA and OGA, were used to serve democratisation programs. These experiments assisted information flow in the Chinese information environment, thus increasing the receptivity of the Chinese government to the access mechanism. Therefore, the traditional argument that economic growth and anti-corruption efforts were the primary rationales for China's FOI reform should be downplayed due to this important, but largely unexplored political factor, coupled with the social factors discussed in Chapter 3.

Apart from political reforms, administrative law reforms assisted in improving information flow in the restrictive Chinese information environment, and so increased China's capacity to accept FOI. This is explored in the next chapter.

\footnotetext{
139 Jiang, above n 99.

$140 \mathrm{Hu}$, above n 30.

141 The Notice on Further Promoting Openness in Government Affairs, above n 97.
} 


\section{5: LAW-BASED ADMINISTRATION AS A RATIONALE FOR FOI REFORM IN CHINA}

\subsection{Introduction}

This chapter examines the influence of administrative law reforms on China's capacity to accept FOI. It explores the history of administrative law reforms, and argues that three decades of administrative law reforms gradually ameliorated the Chinese information environment, resulting in an acceptance of the pull aspect of FOI or reactive disclosure in China. It is difficult for non-Chinese academics to understand why a one-party state such as China would have adopted a tool like FOI legislation for limiting government power (see 1.2.1). The apparently acceptable explanation is that FOI legislation is used by the central government to strengthen bureaucratic control (see 1.4). However, this explanation is inaccurate in its downplaying of three decades of administrative law reform endeavours. While administrative law reform initiatives before the late 1990s did not create an enabling environment for the consolidation of FOI legislation, they facilitated a move of administrative law reforms toward ex ante and procedural controls of government power after the late 1990s. This move increased the capacity to accept FOI as an integral part of law-based administration.

This chapter has three sections. Section one examines the role of administrative law reforms in improving information flow within an information environment. Section two explores the four phases of administrative law reforms in China since the 1980s. It discusses the role of each phase of the reforms in ameliorating the information environment. The final section examines the role of law-based administration associated with administrative law reforms in prompting the Chinese government to accept the pull aspect of FOI. 


\subsection{Administrative law reforms: improving information flow}

The administrative law reform agenda has direct relevance to FOI reform. FOI legislation, which aims to control government power primarily from a procedural perspective, is 'logically part of administrative law'. ${ }^{1}$ However, according to information flow analysis, the adoption of FOI legislation has been facilitated by the improvement of information flow resulting from disclosure requirements set out in other administrative laws prior to the adoption of FOI legislation. China is a case in point. Its FOI legislation originated from the reduction of asymmetry or the improvement of information flow in its longstanding secretive information environment. The reduction or improvement was contributed to by the three decades of administrative law reforms that were a part of the rule of law package after the late 1970s.

\subsubsection{Administrative laws: improving information flow in democracies}

FOI legislation has its origins in other administrative laws that helped to improve flow of information within an information environment. In the US, the Federal Register Act 1935 and the Administrative Procedure Act 1946 became two key heralds of FOI legislation to loosen a secretive information environment. The Federal Register Act 1935 required the publication of all departmental and agency regulations that had 'general applicability and legal effect'. 2 This was the antecedent of the push aspect of information flow. The Administrative Procedure Act 1946 extended the proactive disclosure of government regulations to other standard information in relation to administrative organisation and procedures and the like. ${ }^{3}$ It made a significant breakthrough in the pull aspect of FOI in allowing those individuals 'properly and directly concerned"4 to access information. The drawbacks of the Act, including a number of vague exemptions, lack of general access and failure to provide judicial review of a refusal of access to information, caused the campaign for

\footnotetext{
Robert Vaughn, 'Introduction' in Robert Vaughn (ed), Freedom of Information (2000) xv, xvi. Federal Register Act, 44 USC $\$ 1505$ (1935).

Administrative Procedure Act, 5 USC $\$ 552$ (a) (1) \& (2) (1946).

Administrative Procedure Act of 1946 § 3(c), Pub. L. No 79-404, 60 Stat. 238 (1946).
} 
more robust access legislation. ${ }^{5}$

In Australia, FOI legislation was a key initiative of the New Administrative Law reform agenda that commenced in the early 1970 s. $^{6}$ The reform agenda had three other key initiatives, including the Administrative Appeals Tribunal, the Ombudsman and the Administrative Decision Review, which achieved success a few years earlier than FOI. These initiatives prepared a firm foundation for the FOI initiative, primarily by obliging government agencies to provide a reasoned decision to individuals affected by government decisions. ${ }^{7}$ This obligation was an antecedent of the pull aspect of FOI, and improved information flow within the secretive Australian information environment in the 1970s.

\subsubsection{Administrative law reforms in China: a key part of the rule of law package}

The rule of law program opened the door to administrative law reforms that provided a firm legal foundation for the relaxation of the restrictive Chinese information environment surrounding FOI. The Chinese leadership saw the necessity for law in ruling the country after the end of the Cultural Revolution (1966-1976). Deng observed that there were no laws or legal systems for China to follow for many years, and it was necessary to rebuild the legal system, ${ }^{8}$ which was 'severely damaged" ${ }^{9}$ during the Cultural Revolution. Deng's efforts resolved the ideological confusion that stemmed from the Revolution, and guided China to gradually re-establish its legal system. Jiang continued Deng's policies. A major achievement under Jiang's

5 Stephen Lamble, Computer-Assisted Reporting and Freedom of Information (D Phil Thesis, Queensland University, 2002) 127.

6 John Goldring, 'The Foundations of the "New Administrative Law" in Australia' (1981) 40 Australian Institute of Public Administration 79, 86; Susan Streets, Administrative Law ( $2^{\text {nd }}$ ed, 2000) 27.

7 John McMillan, 'Twenty Years of Open Government: What Have We Learnt?' (Law and Policy Paper No 21, The Federation Press, 2002) 6. The Administrative Appeals Tribunal Act was adopted in 1975. One year later, the Ombudsman Act was passed. The Administrative Decisions (Judicial Review) Act was adopted in 1977.

$8 \quad$ Xiaoping Deng, Selected Works of Xiaoping Deng (Volume II) (in Chinese) (2 $2^{\text {nd }}$ ed, 1994) 147.

9 The State Council Information Office, The White Paper on China's Efforts and Achievements in Promoting the Rule of Law (Beijing, 28 February 2008). 
leadership was the amendment of the Constitution in 1999, which required the government to rule the country in accordance with the law and to build a socialist country under the rule of law. ${ }^{10}$ This revision made the rule of law 'the basic principle in running the country" the rule of law'.12

Whilst administrative law is more difficult to adopt than other laws in China, it has never been excluded from the work of rebuilding the legal system that commenced in the late 1970s. In 1986, Xijin Tao, the former deputy director of the Legislative Affairs Committee of the National People's Congress and a major contributor to this rebuilding effort, argued that China should adopt six basic laws to re-establish its legal system. ${ }^{13}$ Administrative law and administrative litigation law are two of the six basic laws. ${ }^{14}$ Tao's argument made it certain that administrative law would be adopted eventually.

The promotion of the rule of law since 1999 increased the importance of the development of law-based administration that has been closely associated with administrative law reforms in recent years. ${ }^{15}$ In China, law-based administration was accepted by the central government much earlier than the rule of law, but the importance of this administration did not increase until the promotion of the idea of becoming a country under the rule of law in $1999 .{ }^{16}$ The Chinese government states that law-based administration is essential for overall implementation of the rule of

The Constitution 1982 (China) Art 5.

Zemin Jiang, 'Build a Well-off Society in an All-Round Way and Create a New Situation in Building Socialism with Chinese Characteristics' (in Chinese) (Speech delivered at the $16^{\text {th }}$ National Congress of the CPC, Beijing, 8 November 2002).

12 The State Council Information Office, above $n 9$.

13 Songnian Ying, 'Overview and Expectations of China's Administrative Law' (in Chinese) (2008) 2 The Rule of Law Forum 1, 2.

14 Ibid. The other four basic laws are criminal law, civil law, criminal litigation law and civil litigation law.

15 Jiabao Wen, 'Pushing Forward Administration by Law in an All-Round Way to Build a Government under the Rule of Law' (in Chinese) (Speech delivered at the National Picturephone Conference on the Work of Law-Based Administration, Beijing, 28 June 2004).

16 'Law-Based Administration: From Government Ruled by Law to Government under the Rule of Law' (in Chinese) Legal Daily (Beijing) 6 July 2008, 6. 
law ${ }^{17}$ and lies at its core. ${ }^{18}$ This was supported by the Chinese government in its policy document of 2004, titled 'Implementation Outline for pushing forward Administration by Law in an All-Round Way'. ${ }^{19}$

The rule of law appears at odds with a one-party state. The existing literature, especially that authored by non-Chinese academics, has therefore dismissed the potential significance of taking the rule of law as a goal of China's political development. ${ }^{20}$ While it will be a long process for China to realise a state where the rule of law prevails, the process has begun with an unprecedented adoption of myriad laws at national and local levels. ${ }^{21}$

\subsection{Administrative law reforms: a firm basis for FOI legislation}

A series of administrative law reforms during the last three decades provided an opportunity for the improvement in the Chinese information environment. This made FOI reform more compatible with the changed information environment. In general, developments in administrative law in China can be classified into four phases, but only the recent phase of administrative law reforms has increased the Chinese government's willingness to allow citizens affected by government decisions to access information. The recent phase of administrative law reforms provided a foundation for the acceptance of the pull aspect of FOI, especially after the

17 The State Council Information Office, above $\mathrm{n} 9$.

18 The Decision of Pushing Forward Administration by Law in an All-Round Way No 23 [1999] of the General Office of the State Council.

19 The Implementation Outline for Pushing Forward Administration by Law in an All-Round Way No 10 [2004] of the General Office of the State Council.

20 Peerenboom in his book notes this dismissal by most western observers, but he suggests that China's efforts to establish rule of law should be taken seriously. See Randall Peerenboom, China's Long March toward Rule of Law $\left(1^{\text {st }}\right.$ ed, 2002) xii. Zimmerman also argues that '[p]rolific legislative activity and increased emphasis on implementation and enforcement are positive steps and indicative that China is serious about the establishment of a genuine legal system based upon the rule of law'. See James Zimmerman, China Law Deskbook (2 ${ }^{\text {nd }}$ ed, 2005) 70.

21 During the last three decades, it has seen the fundamental establishment of a socialist legal framework. The National People's Congress and its Standing Committee have enacted 229 laws currently in effect, covering almost all substantive and procedural areas. Apart from this, the State Council has enacted nearly 600 administrative regulations, and local congresses and governments enacted thousands of local regulations and rules currently in effect. See The State Council Information Office, above $\mathrm{n} 9$. 
incorporation of the pull aspect into a law-based administration reform package. Figure 5 highlights the role of the different phases of focus for administrative law reforms in contributing to China's capacity to accept FOI.

Figure 5 The role of administrative law reforms in improving information flow

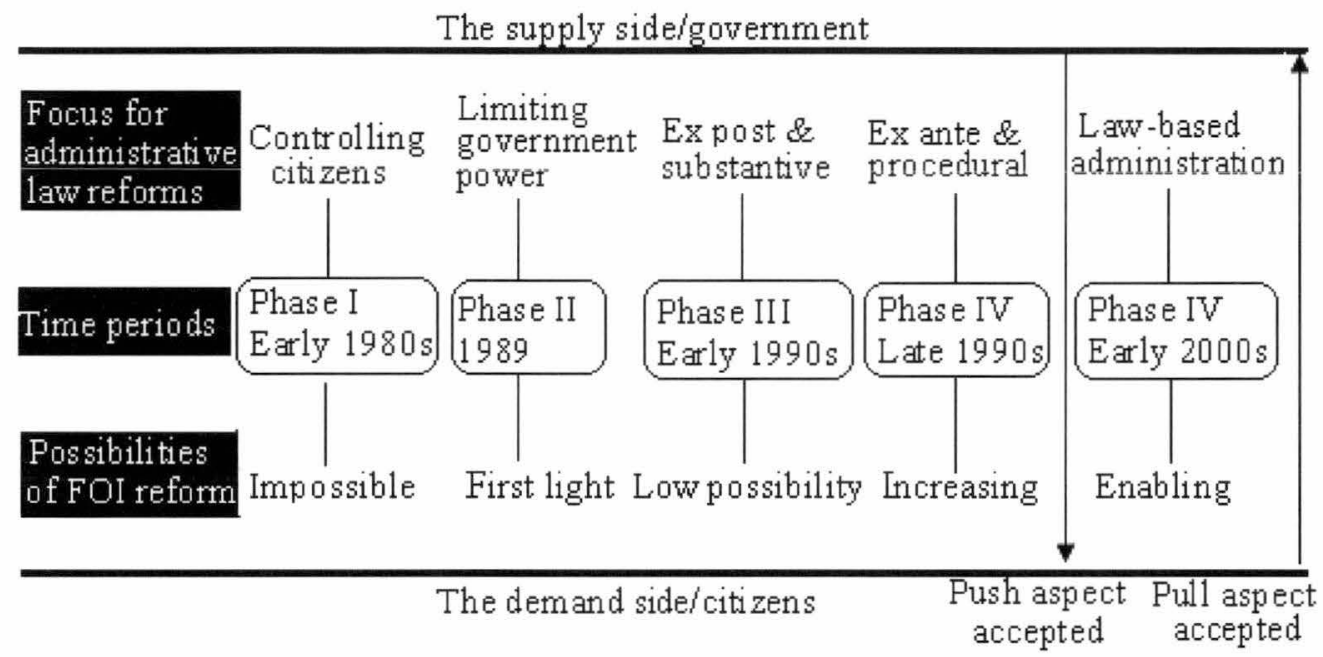

\subsubsection{The early 1980s: the preliminary stage}

Administrative law reforms in the early 1980s did not provide a favourable legal foundation for increasing the Chinese government's willingness to accept FOI reform. Administrative law reforms generally followed the line of controlling or limiting government power during the last three decades. ${ }^{22}$ However, administrative law reforms in the early 1980s, a preliminary stage of the reforms, lacked respect for this principle. ${ }^{23}$ The reforms were guided by the principle of controlling citizens, ${ }^{24}$ and administrative laws adopted during this period had this striking feature. This

22 Gangling Xue, Discovering the Roadmap for the Rule of Administrative Law: Combined Works of Professor Xue Gangling (in Chinese) (1 ${ }^{\text {st }}$ ed, 2006) 4. There are other theories, which define the nature of administrative law in China, like theories of administration, service and balance. Especially theory of balance, first proposed by Professor Haocai Luo, holds that administrative law should be a law to balance between government powers and citizens' rights. However, this theory 'does not reject the notion of power control'. See Jianfu Chen, Chinese Law: Towards an Understanding of Chinese Law, Its Nature, and Development (1 $\left.{ }^{\mathrm{st}} \mathrm{ed}, 1999\right) 135-9$.

23. Jian Han and Junliang Wang, The Basic Theory and Practice of Law-Based Administration in China (in Chinese) $\left(1^{\text {st }}\right.$ ed, 2006) 42.

24 Chunying Xin and Jun Feng, WTO and China's Administrative Law Reforms (in Chinese) $\left(1^{\mathrm{st}} \mathrm{ed}\right.$, 2005) 140. 
controlling philosophy could not accept transparency as its key value, and so transparency played little or no role in this era of Chinese administrative law.

However, administrative law reforms, to a degree, did occur during this period. First, the principle of law-based administration was implicitly expressed under the Constitution 1982. The Constitution states that all state agencies must abide by the Constitution and the law, and requires all acts in violation of the Constitution or the law to be investigated. ${ }^{25}$ This principle weakened the habitual behaviour of government agencies exercising their power through policies or leaders' instructions rather than laws. ${ }^{26}$ The Constitution also allows citizens who have suffered losses as a result of infringement of their civic rights by any public bodies to claim compensation pursuant to the law. ${ }^{27}$ While the Constitution only implies law-based administration, it declares that government agencies must abide by the Constitution and the law. ${ }^{28}$ This has become a firm direction for administrative law reforms.

Second, government power could be challenged. Administrative litigation was allowed under the Civil Procedure Law $1982,{ }^{29}$ but the scope of these suits was limited. To separate administrative cases from civil ones, the Supreme Court set up special procedures for trying administrative cases and directed courts to establish administrative tribunals after the adoption of Regulations on Administrative Penalties for Public Security $1986 .^{30}$ These measures prepared the ground for the introduction of the Administrative Litigation Law.

Arguably, the role of administrative law during this initial era of law reform was marginal and limited. It was rarely used to call to account, challenge or litigate against government activities. If this occurred, it was circumscribed and rare. ${ }^{31}$ Ordinary citizens were generally unable to take government agencies to court except

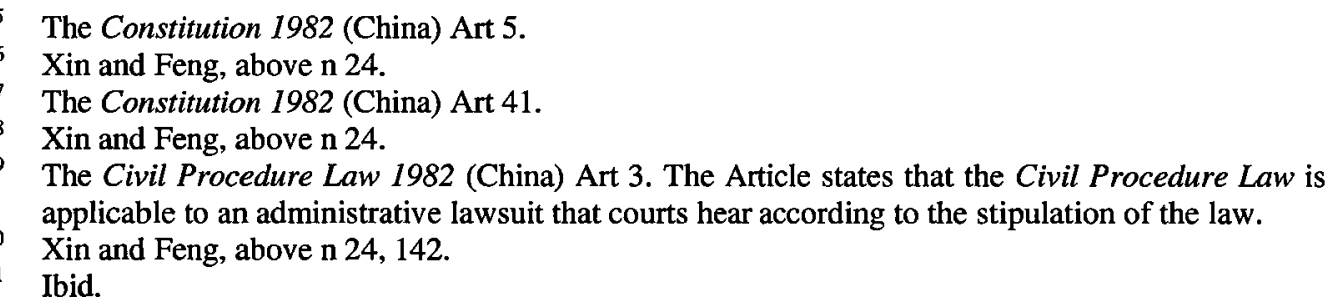


for administrative lawsuits on economic activities. ${ }^{32}$ Thus, the Chinese government's willingness to make transparency a key value of administrative laws was weak. As a result, the focus on controlling citizens in this period of administrative law reforms made no contribution to the transformation of the longstanding secretive information environment. In other words, the capacity to accept FOI was negligible in this largely unchanged environment.

\subsubsection{The late 1980s: the starting point}

After the late 1980s, administrative law reforms shifted to placing limitations on government action. This made it possible for the improvement of the Chinese information environment and the capacity to envisage FOI by gradually accepting transparency as a key value of administrative law. The adoption of Administrative Litigation Law 1989, being the second phase of administrative law reforms, initiated an emphasis on controls of government power. ${ }^{33}$

The work of rebuilding the legal system was not completed in the $1980 \mathrm{~s}$, as there was no administrative law. ${ }^{34}$ Administrative law was a new area unfamiliar to Chinese law academics and legislatures. ${ }^{35}$ It was recommended that an Administrative Legislation Research Group should be established to draft important administrative laws. ${ }^{36}$ The group was established in 1986 to draft a comprehensive administrative basic law, which covered any substantive aspect of this area, like the Civil Code $1986 .^{37}$

However, a year later the research group announced that it was impracticable to draft such a comprehensive law at that stage. ${ }^{38}$ It decided that the reform needed to be completed in stages. ${ }^{39}$ After learning that the National People's Congress was being

Ibid.

Ibid 143.

Ying, above $n 13$.

Songnian Ying, 'Overview and Expectations of China's Administrative Law' (Speech delivered at Zhongshan University, Zhongshan, 6 January 2006).

36 Ibid. China did not establish a similar research group for the introduction of its civil and criminal law. This indicates the difficulty of the adoption of administrative law.

Ibid.

Arthur Cheung, 'China's Administrative Litigation Law' (2005) Autumn Public Law 549, 551.

Ying, above $n 13$. 
considered for the revision of the Civil Procedure Law 1982, experts in this group saw this as an opportunity to introduce a special administrative litigation law. ${ }^{40}$ Ping Jiang, the director of this group, said that the adoption of procedural laws prior to substantive laws could make it easier to pass substantive laws. ${ }^{41}$ This process adhered to China's legislative tradition. ${ }^{42}$ Ming'an Jiang, a member of the group, said that this was compatible with the situation in China because the lack of such legislation impeded the process of a number of administrative lawsuits at that time. ${ }^{43}$

As a result, the Administrative Litigation Law, an important law checking administrative actions, became the first of a series of special administrative laws. ${ }^{44}$ The Law was adopted on 4 April 1989, and took effect on 1 October $1990 .{ }^{45}$ Chinese academics assert that the milestone Administrative Litigation Law made the rulers and the ruled equal before the law in China, ${ }^{46}$ allowing citizens to sue government for the first time. ${ }^{47}$ This Law thus became the starting point of China's administrative law reform. ${ }^{48}$ The Administrative Litigation Law contradicted the view that 'law [was] not a limit on the party-state ${ }^{49}$ More importantly, it signalled a focus of administrative law reforms on controlling government power and regulating administrative actions. ${ }^{50}$

40 Ibid. Administrative litigation was partly allowed under the Civil Procedure Law 1982.

41 Ying, above $\mathrm{n} 35$.

42 Chinese reformers were inspired by the re-establishment of civil law. China adopted its Civil Procedure Law four years earlier than that of Civil Code. See Ying, above $\mathrm{n} 35$.

43 Wen Dun, Interview with Ming'an Jiang, Professor of Peking University (Beijing, 29 September 2003).

44 Songnian Ying, 'The Establishment of China's Administrative Law and the Problems Encountered' (in Chinese) (2001) I Journal of Jianghai Academia 60, 61.

45 The law has restrictions. For example, the law only permits courts to review the lawfulness of concrete administrative actions. The Administrative Litigation Law 1989 (China) Art 2.

46 Cheung, above n 38, 549; Xin and Feng, above n 24, 143.

47 'Law-Based Administration: From a Government Ruled by Law to a Government under the Rule of Law' above $n 16$.

48 Dun, above $\mathrm{n} 43$.

49 Pitman Potter, 'The Chinese Legal System: Continuing Commitment to the Primacy of State Power' (1999) 159 The China Quarterly 673, 674.

50 Xin and Feng, above n 24,143. 


\subsubsection{The early 1990s: controls of government power from ex post and substantive perspectives}

Administrative law reforms in the early 1990s, the third phase of the reforms, focused on controls of government power from ex post and substantive perspectives. Transparency was not regarded as a core value of administrative law, and thus this phase of administrative law reforms contributed little to the improvement of information flow in the restrictive Chinese information environment. Therefore, the capacity to accept FOI remained minimal during this era.

There were two key features of administrative law reforms in the early 1990s. First, the reforms concentrated more on ex post than ex ante controls of government power. ${ }^{51}$ This is illustrated through the establishment of the administrative supervision legal system. The Administrative Litigation Law 1989 standardised external supervision by Chinese courts. However, its role is limited because it only provides judicial review of the lawfulness, rather than the reasonableness, of administrative actions. ${ }^{52}$

Administrative reconsideration provides another remedial channel for Chinese citizens. It was first institutionalised in 1990 by Administrative Reconsideration Regulations, which was promoted to Administrative Reconsideration Law in 1999. The Law standardises internal review by superior government agencies. It extends the protection of ordinary citizens' remedial rights by empowering an administrative reconsideration agency to review not only the lawfulness, but the reasonableness, of concrete administrative actions. ${ }^{53}$ In addition, some abstract administrative actions

\footnotetext{
Han and Wang, above $\mathrm{n} 23$.

The Administrative Litigation Law 1989 (China) Art 5.

The Administrative Reconsideration Law 1999 (China) Art 3. A concrete administrative action refers to an administrative activity of government agencies which aims at specified events or individuals and can only be carried out once, while an abstract administrative action is an activity which aims at the general public and can be repeatedly carried out. These two kinds of actions attract different supervision and control mechanisms and legal remedies. China's Administrative Litigation Law allows only a concrete administrative action to be reviewed by courts.
} 
are subject to administrative reconsideration. ${ }^{54}$

Apart from administrative lawsuit and reconsideration systems, Chinese reformers considered that specialised supervision was important to control government power. The Audit Law, adopted in 1995, empowers audit offices to audit revenues and expenditures of government agencies and public institutions. ${ }^{55}$ The Administrative Supervision Law, adopted in $1997,{ }^{56}$ standardises the supervision of government agencies and government officials by supervisory agencies, China's Ombudsmen. ${ }^{57}$

Second, administrative law reforms during this period focused more on controlling government power through substantive laws than procedural ones. ${ }^{58}$ The Administrative Litigation Law did not set out the details of state compensation, although it allowed a person who suffered damage to claim compensation. ${ }^{59} \mathrm{~A}$ comprehensive compensation system was established after the adoption of the State Compensation Law 1994. Luo said that the State Compensation Law' forced the state in descending from the divine altar ${ }^{60}$ because there was no tradition in China that encouraged government agencies and officials to apologise for their mistakes and pay compensation. Besides, Interim Regulations on Civil Servants were adopted in 1993, which made it possible for China to develop public service professionalism. After 12 years of operation, the Regulations were promoted to the Civil Servant Law, passed in 2005. This Law comprehensively standardised personnel management in China for the first time. ${ }^{61}$

The initial set of administrative law reforms was supplemented by the adoption of a number of administrative laws in the early 1990s. However, the focus on ex post and

54 The Administrative Reconsideration Law 1999 (China) Art 7.

55 The Audit Law 1995 (China) Art 2.

56 The Administrative Supervision Law was adopted after the early 1990 s, but the debate ran earlier. The thesis thus includes it in this phase of administrative law reform.

57 The Administrative Supervision Law 1997 (China) Art 7.

$58 \quad$ Xin and Feng, above n 24, 143.

59 The Administrative Litigation Law 1989 (China) Art 67.

60 Haocai Luo, The Current Trend in Modern Administrative Law (in Chinese) (1 $\left.{ }^{\text {st }} \mathrm{ed}, 2004\right) 39$.

61 Qinghong Zeng Stresses the Comprehensive Recognition of the Significance of the Passage of the Civil Servant Law (in Chinese) (2005) The Central Government <http://www.gov.cn/zfjs/200509/22/content_68644.htm $>$ at 9 February 2008. 
substantive controls of government power during this period did not facilitate information flow that could relax the secretive Chinese information environment, and thus FOI was not prioritised during this period.

\subsubsection{The late 1990s to now: controls of government power from ex ante and procedural perspectives}

The fourth phase of administrative law reforms after the late 1990s emphasised controls of government power from ex ante ${ }^{62}$ and procedural ${ }^{63}$ perspectives. This directly contributed to the relaxation of previous restrictive information environment and to the increase in China's capacity to accept FOI. In this phase of administrative law reforms, procedural due process became a key value of administrative law, and administrative transparency was regarded as a key element inherent in administrative law.

\section{Procedural due process: a key value}

Procedural due process became a key value of administrative law reforms during this period of reform, causing administrative transparency to be incorporated into a number of administrative laws adopted after the late 1990s. Hearings and information disclosure are two key parts of procedural due process derived from natural justice. ${ }^{64}$ Hearings were first introduced into China in 1996 under the Administrative Penalty $L a w,{ }^{65}$ which requires government agencies to inform the aggrieved parties about their right to a public hearing before imposing serious administrative penalties. ${ }^{66}$ Other laws, such as the Price Law 1997 and the Legislation Law 2000, also set out price and law hearings respectively. ${ }^{67}$ Hearings are now not limited to individuals who may be aggrieved by a concrete administrative action, but are extended to the

Han and Wang, above $\mathbf{n} 23$.

Xin and Feng, above $\mathbf{n} 24,144$.

Goldberg v Kelly, 397 US 254, 267-8 (1970); Streets, above n 6, 157-8; McMillan, above n 7, 42.

Xin and Feng, above n 24, 145.

The Administrative Penalty Law 1996 (China) Art 42. Some examples of the serious administrative penalties are suspending production and business operations, revoking certificates or business licences and imposing relatively large fines.

67 The Price Law 1997 (China) Art 23; The Legislation Law 2000 (China) Art 34, 58. 
general public who may be influenced by an abstract administrative action, such as law-making and decision-making. For instance, the Administrative Permission Law 2003 requires government agencies to hold public hearings for implementing administrative permissions under law, regulation or rule. ${ }^{68}$ The hearing requirements under a number of administrative laws have assisted information flow and relaxed the previous restrictive information environment.

\section{Administrative transparency: inherent in administrative law}

Administrative transparency has been regarded as inherent in administrative law in China since the middle 1990s. ${ }^{69}$ Procedural due process requires administrative transparency, ${ }^{70}$ which is central to modern administrative law ${ }^{71}$ and has become a key guide for administrative law reforms in China. ${ }^{72}$ This occurs in the following two areas.

First, laws and regulations must be published, and unpublished laws and regulations cannot be the basis of administrative decisions, as the Administrative Penalty Law 1996 and the Administrative Permission Law 2003 demonstrate. ${ }^{73}$ The Legislation Law 2000 standardises the openness of legislation, but requires only a limited degree of publicising draft laws. ${ }^{74}$ In 2008, the Standing Committee of the NPC decided to make draft laws public in principle. ${ }^{75}$ In the same year, the State Council also committed to publishing draft bills or administrative regulations that closely involve

68 The Administrative Permission Law 2003 (China) Art 46.

69 Xin and Feng, above n 24, 145.

70 Jianmiao Hu and Lianji Ma, 'The Legal Foundation for Government Management and FOI' (in Chinese) (2005) 4 Legal Forum 13, 16.

71 Yuchuan Mo, 'From Sunshine Government to Government under the Rule of Law' in Yuchuan Mo and Hongchao Lin (eds), Interpretations of China's FOI Regulations (in Chinese) (2008) 1, 2.

72 Hai Yan, Theory and Practice in Government Information Publicity (in Chinese) (1t ed, 2008) 41.

73 The Administrative Penalty Law 1996 (China) Art 4; The Administrative Permission Law 2003 (China) Art 5.

74 The Legislation Law 2000 (China) Art 35.

75 Doudou Ye, Openness in Law-Making Activity Is Underway (in Chinese) (2008) Caijing <http://www.caijing.com.cn/2008-09-03/1 10009953.html> at 3 October 2008. 
the interests of the people. ${ }^{76}$ The mandatory publication of laws, regulations and rules fell into the category of the push aspect of information flow, which enhanced information flow in a way that can support FOI.

Second, government agencies are obliged to provide a full account of decisions to any person who may be aggrieved by an administrative action. This obligation has been extended to a number of administrative laws adopted since 1996. The Administrative Penalty Law 1996 requires government agencies to notify the aggrieved parties of the facts, grounds and basis on which the decision is made, as well as the rights that the parties enjoy according to the law before making the decision to impose administrative penalties. ${ }^{77}$ The Administrative Permission Law 2003 requires government agencies to disclose their decision on approving administrative permission, and allows the public to access this decision. ${ }^{78}$ The obligation to provide reasons for government decisions was a key antecedent of the pull aspect of FOI in China. It helped increase the government's receptivity to a general right to access information.

Administrative law reforms after the late 1990s, which focused on ex ante and procedural controls of government power, made it possible for the relaxation of the secretive Chinese information environment. The background of FOI, including the hearings, the publication of laws and rules and the giving of reasons for an administrative decision, facilitated information flow from the government to society. This has contributed to a significant change in the secretive Chinese information environment. The push aspect of information flow, although very limited, has become a firm basis for a general access mechanism.

76 Jiabao Wen, 'Report on the Work of the Government to the National People's Congress' (Speech delivered at the First Session of the $11^{\text {th }}$ National People's Congress, Beijing, 5 March 2008); Working Rules of the State Council No 14 [2008] of the State Council.

77 The Administrative Penalty Law 1996 (China) Art 31.

78 The Administrative Permission Law 2003 (China) Art 40. 


\subsection{FOI legislation: an integral part of law-based administration}

The law-based administration reform agenda directly brought about the official acceptance of the access mechanism, the pull aspect of FOI. Administrative law reforms cannot be achieved without Chinese political leaders' agreement and commitment to building law-based administration. Law-based administration was first raised by former Premier Peng $\mathrm{Li}$ in $1993 .{ }^{79}$ Political leaders first formally expressed their support for building law-based administration in the political report of the $15^{\text {th }}$ National Congress of the Communist Party of China in $1997 .{ }^{80}$ The central endorsement of law-based administration facilitated developments of administrative law in China.

2004 was a turning point for the promotion of law-based administration, which showed the official acceptance of the pull aspect of FOI in China. While the State Council issued a policy document in 1999 to implement the central support for lawbased administration, ${ }^{81}$ this document did not mention transparency. The Hu-Wen administration since 2003 was determined to take law-based administration as one of its three overarching tasks (see 4.3.1). Thus, the Implementation Outline for Pushing Forward Administration by Law in an All-Round Way (Implementation Outline) was published in 2004, which set the goal to realise a government under the rule of law before 2014, rather than merely law-based administration. ${ }^{82}$ The Implementation Outline provided for the guidelines and specific targets, basic principles and requirements, as well as major tasks and measures for overall implementation of lawbased administration.

79 Peng Li, Report on the Work of the Government to the National People's Congress (Speech delivered at the First Session of the Eights National People's Congress, Beijing, 15 March 1993).

80 Zemin Jiang, 'Hold High the Great Banner of Deng Xiaoping Theory for an All-round Advancement of the Cause of Building Socialism with Chinese Characteristics to the $21^{\text {st }}$ Century' (in Chinese) (Speech delivered at the $15^{\text {th }}$ National Congress of the CPC, Beijing, 12 September 1997).

81 The Decision of Pushing Forward Administration by Law in an All-Round Way, above $\mathrm{n} 18$.

82 The Implementation Outline for Pushing Forward Administration by Law in an All-Round Way, above $\mathrm{n} 19$. 
It is highly significant that this key central policy document took transparency seriously. It regarded procedural due process as a key principle of law-based administration. This was the outcome of the recent trend of administrative law reforms that have turned toward ex ante and procedural controls of government power. The Implementation Outline regarded administrative transparency as a key part of implementing procedural due process. It required government agencies to disseminate any information, subject to statutory exemptions, when undertaking administrative practices. ${ }^{83}$ It also required government agencies to disclose information on the exercise of administrative management to the concerned parties in order to safeguard their rights to know, participate and remedy. ${ }^{84}$

More importantly, the Implementation Outline treated FOI legislation as an integral part of law-based administration. This treatment directly resulted in the acceptance of the pull aspect of FOI in China. To encourage the introduction of FOI legislation in China, the Implementation Outline put forward three basic requirements: government agencies should be liable to disclose government information except those involving state secrets, trade secrets or privacy; the public should have a right to access government information; and government agencies should facilitate public access. ${ }^{85}$ The acceptance of the pull aspect of FOI caused FOI legislation to rise to the top of political agenda.

The Implementation Outline has had a great influence on administrative law reforms in China. It has set clear goals for the establishment of law-based administration, and become an enforceable working plan for the Chinese government. FOI legislation, which was adopted in 2007 , was just one of the plans on the schedule.

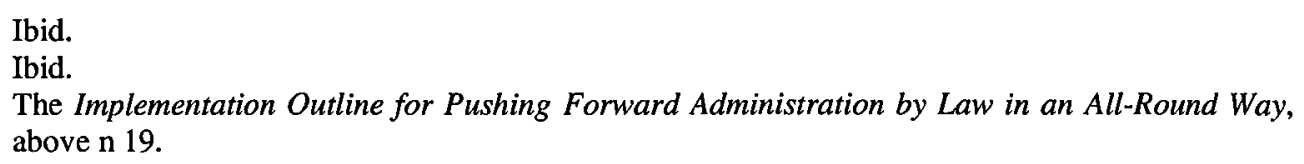




\subsection{Conclusion}

This chapter argues that the recent administrative law reform agenda, which moved toward controls of government power from ex ante and procedural perspectives, presented the opportunity to increase China's capacity to accept FOI. Administrative transparency has been incorporated into a number of administrative laws adopted since the late 1990s. This resulted in the improvement of information flow in the Chinese information environment, making FOI more compliable with this improved environment. The central government's law-based administration initiative in 2004, coupled with administrative law reforms, finally resulted in the acceptance of FOI in China. Therefore, the traditional accounts of economic growth and anti-corruption efforts for China's FOI reform should be downplayed due to this important but insufficiently recognised factor of administrative law reforms, together with the social and political factors discussed in Chapters 3 and 4.

The next chapter reassesses the role of economic growth and anti-corruption efforts in contributing to China's FOI reform. 


\section{6: REASSESSMENT OF ECONOMIC GROWTH AND ANTI-CORRUPTION EFFORTS AS RATIONALES FOR FOI REFORM IN CHINA}

\subsection{Introduction}

This chapter examines the roles of two main driving forces - economic growth and anti-corruption efforts - in influencing China's capacity to accept FOI. It argues that these two forces should be accorded an important but secondary role in FOI reform, as they only have a limited and indirect influence on relaxing the secretive Chinese information environment. It is thus necessary to reassess their roles and examine further their extent and nature. FOI reform was initiated to strengthen the new mode of economic growth (see 1.2.4), that is, informatisation, a term which is different from information flow and used in this thesis to refer to the modernisation of China's information technology infrastructure. Furthermore, FOI reform was promoted to improve the efficiency of anti-corruption efforts (see 1.2.4). However, this thesis finds that these two driving forces have arguably been overstressed in the existing literature. This is because the social, political and legal contexts connected with FOI have been largely unexplored (see Chapters 3,4 and 5). The unexplored parts of the historical background to the introduction of FOI in China have also resulted in these two motives being overstated.

This chapter has two sections. Section one reassesses economic development as a driving force for FOI reform in China. It explores a normative view on the economic growth motive for FOI reform in China, and re-examines the role of informatisation in driving FOI reform in China. Section two reassesses the anti-corruption efforts as a rationale for FOI reform in China. It explores the role of FOI as a tool for preventing 
corruption, and re-examines the role of anti-corruption efforts in driving FOI reform in China.

\subsection{Reassessing economic development as a rationale for FOI}

This thesis argues that the economic growth motive for FOI reform in China has been overstated in the existing literature. ${ }^{1}$ This has hindered the exposure and examination of other primary driving forces, including the social, political and legal ones discussed in Chapters 3,4 and 5. The normative view on economic growth as a driving force of FOI reform in China has presented strong evidence for non-Chinese experts $^{2}$ to rationalise China's strange and unexpected growth of FOI. However, the normative view has significant deficiencies in fully describing the actual influence of economic growth on FOI reform. Upon closer examination, this thesis reveals two layers of the economic growth rationale for FOI reform in China. China's FOI reform was originally a response to the revision of the Law on the Protection of State Secrets 1988. At a later date, Chinese reformers made FOI reform politically acceptable from the standpoint of informatisation development. This effort was strengthened after the support of informatisation agencies and China's accession to the World Trade Organisation (WTO) in 2001.

\subsubsection{The normative view on the economic growth motive for FOI reform in China}

The following explanation for China's FOI reform is currently dominant in the FOI literature. Rather than 'moral considerations' ${ }^{3}$ like more transparent and responsible

Colin Darch and Peter Underwood, Freedom of Information and the Developing World: The Citizen, the State and Models of Openness $\left(1^{\text {st }} \mathrm{ed}, 2009\right) 171$; Jamie Horsley, China Adopts First Nationwide Open Government Information Regulations (2007) Freedom of Information Organisation <http://www.freedominfo.org/features/20070509.htm> at 28 August 2007; Paul Hubbard, 'China's Regulations on Open Government Information: Challenges of Nationwide Policy Implementation' (2008) 1 Open Government: A Journal on Freedom of Information <http://www.opengovjournal.org/article/viewArticle/2651> at 22 July 2009.

2 See above $\mathrm{n} 1$ and the accompanying text.

3 Thomas Blanton, 'The Openness Revolution: The Rise of a Global Movement for Freedom of Information' (2002) 1 Development Dialogue 7, 16. 
government, it is said that 'utilitarian considerations' ${ }^{4}$ such as economic growth led to the acceptance of FOI reform. ${ }^{5}$ In retrospect, an alternative and more persuasive explanation for the economic growth motive or a normative view on this motive is as follows. FOI can be seen as a minor but important accompaniment on the roadmap that the Chinese leadership followed in making economic growth the central task in China. ${ }^{6}$ Informatisation has been regarded as a new and rational choice to develop the economy after the reconsideration of the direction and type of economic growth in China since the late $1990 \mathrm{~s}^{7}{ }^{7}$ Reuse or exploitation of government information, a vital part of developing informatisation, was recognised as a priority. ${ }^{8}$ Furthermore, FOI was considered as an important method for facilitating this reuse, and therefore became part of the movement toward informatisation development. ${ }^{9}$

The normative view, which only reflects a narrow part of the Chinese FOI story, is likely to be misleading about the origins of China's FOI reform. The economic growth impetus is important. The move toward FOI reform was boosted by its ability to reuse government information, which refers to the use of government information

\section{Ibid.}

5 Darch and Underwood, above n I; Blanton, above n 3; Toby Mendel, 'Corruption, Access to Information and Human Development' (Draft at 9 August 2008); Graham Sutton and Sarah Holsen, 'China Progresses Information Access and Data Protection Laws' (2006) 2 Open Government: A Journal on Freedom of Information <http://www.opengovjournal.org/ article/ view/621/482> at 22 July 2009.

6 Chinese political leaders have taken economic growth as the central task of nation building since the late 1970s. See Xiaoping Deng, Selected Works of Xiaoping Deng (Volume III) (in Chinese) $\left(2^{\text {nd }}\right.$ ed, 1994) 194.

7 The previous mode of economic growth that emphasised the development of heavy industry impaired the development of light and service industries, thus leading to an unreasonable economic structure. Considering this, the central government decided to develop informatisation to modify the traditional mode of economic growth. This new mode was first formally confirmed by the Chinese government in 2000, when informatisation development was called for to upgrade industrialisation. This was reiterated in 2002 at the $16^{\text {th }}$ National Congress of the CPC. See The CPC Central Committee, Communique of the Fifth Plenary Session of the $15^{\text {th }}$ CPC Central Committee (2000); Zemin Jiang, 'Build a Well-off Society in an All-Round Way and Create a New Situation in Building Socialism with Chinese Characteristics' (in Chinese) (Speech delivered at the $16^{\text {th }}$ National Congress of the CPC, Beijing, 8 November 2002); Jinlian Wu, 'Which Path of Industrialisation Should China Take?' (in Chinese) (2006) 8 Management World 1, 4.

8 Explanation Memorandum, The Draft of FOI Regulations 2002 (China) 14; Suggestions on Strengthening Exploitation and Use of Information Resources No 34 [2004] of the General Office of the CPC Central Committee.

9 Ibid. It is argued that government agencies, which hold more than 80 percent of information, should be the main providers of information for reuse. 
for commercial purposes. However, the reuse initiative can only increase the willingness of the government to share economically valuable information. It cannot motivate the government to disclose socially valuable but economically unimportant information. This means that the role of economic growth in increasing flow of general information and the capacity to accept FOI was weak. Other largely unexplored driving forces, including social, political and legal conditions played more primary and direct roles than economic growth in contributing to the acceptance of FOI.

\subsubsection{FOI and informatisation: a casual connection}

There is a casual, rather than causal, connection between informatisation development and FOI. This indicates that the role of the information reuse initiative in increasing the Chinese government's willingness to share more general information with the public is not prominent or urgent. A key feature of informatisation is reuse of information resources, ${ }^{10}$ but FOI lacks a direct and strong association with information reuse. Gellman states that FOI legislation is 'insufficient to meet all public needs for government information, and it is sometimes administered indifferently by the agencies'. ${ }^{11}$

However, Chinese reformers originally presumed that FOI legislation would benefit reuse of government information. ${ }^{12}$ Zhou holds the view that a key reason for the adoption of FOI legislation in China is that informatisation and an information society require reuse of government information to develop the economy. ${ }^{13} \mathrm{He}$ cited two examples, The Green Paper on Public Sector Information ${ }^{14}$ issued by the EU Commission and the Comprehensive Assessment of Public Information

$10 \quad$ Hanhua Zhou, Academic Draft of FOI Regulations (in Chinese) ( $\left.1^{\text {st }} \mathrm{ed}, 2003\right) 19$.

11 Robert Gellman, 'The Foundation of United States Government Information Dissemination Policy' in Georg Aichholzer and Herbert Burket (eds), Public Sector Information in the Digital Age - Between Markets, Public Management and Citizens' Rights (2004) 123, 126.

12 Zhou, above n 10, 19-20; Explanation Memorandum, above n 8.

13 Zhou, above n 10, 19-20.

14 The EU Commission's Green Paper on Public Sector Information was published in 1998. It largely dealt with problems impeding exploitation of public sector information. The EU Commission, Green Paper on Public Sector Information Com (1998) 585. 
Dissemination published by the US National Commission Libraries and Information Science ${ }^{15}$ to support his argument. However, these two documents focused more on reusing, rather than accessing public sector information. Zhou is of the opinion that FOI legislation would be most likely to bring about the reuse of information and the development of informatisation in China. ${ }^{16}$

\section{Impediments to reuse from FOI legislation}

Zhou's observation seems to overestimate the prospects of FOI for reuse of government information, especially when compared to the experiences in the US, Australia and the EU. FOI legislation and its implementation may not facilitate any reuse of information due to its broad exemptions, long processing time and high request fees. ${ }^{17}$ Commercial information commonly falls within an exemption under FOI legislation, and is overprotected and overused in practice. ${ }^{18}$ Australia serves as an example. The commercial-in-confidence exemption under Australian FOI legislation was overused in the past, and this overuse will be likely to continue in the future, especially with the ever increasing contracting-out of government services. ${ }^{19}$ As a result, Australian businesses have made low use of FOI legislation. ${ }^{20}$ A former Australian Attorney-General expected that more businesses would use this legislation to access large amounts of non-confidential information with commercial value, ${ }^{21}$ but the reality did not meet his expectation.

15 The Comprehensive Assessment of Public Information Dissemination, which was published in 2001 , focused on issues arising from dissemination and emphasised that public information was a strategic national resource. See The US National Commission Libraries and Information Science, The Comprehensive Assessment of Public Information Dissemination (2001) <http://www.nclis. gov/govt/assess/assess.execsum.pdf $>$ at 27 March 2008. Zhou, above n 10, 19-20.

17 For example Australia. The Australian Attorney-General's Department and the Ombudsman's annual reports on FOI have repeatedly mentioned these problems.

18 This is the case in Australia. Ron McLeod, 'Freedom of Information' (Paper presented at the Seminar on Freedom of Information - A Current Perspective, 21 February 2000).

19 Ibid.

20 Stephen Lamble, 'Media Use of FOI Surveyed: New Zealand Puts Australia and Canada to Shame' (2004)109 Freedom of Information Review 5, 5; Moira Paterson, 'Transparency in the Modern State Happy Birthday FOI! or Commiserations?' (2004) 29 Alterative Law Journal 10, 10.

21 The Australian Attorney-General's Department, Freedom of Information Act 1982 Annual report 1986-1987, iii; 1987-1988, iv. 
The key reason for the low use of FOI by Australian business is the overprotection of the release of third party information, and this has discouraged the commercial use of FOI legislation. ${ }^{22}$ This was a response to the concerns of private bodies about the possibility of release of sensitive commercial information supplied to the government. ${ }^{23}$ In practice, government agencies have applied a 'mere possibility" ${ }^{24}$ standard of proof, rather than 'reasonable expectation of damage' 25 to the commercial-in-confidence exemption. Such application has broadened the scope of this exemption.

\section{FOI as only one positive factor for reuse}

The effect of government information reuse on economic growth cannot be maximised simply by relying on FOI legislation. FOI legislation only provides a mechanism for the public to access government information; it does not set out a provision that permits the public to exploit or reuse the information sought. At least four mechanisms are needed to facilitate reuse of government information: a strong FOI law, a maximum fee limited to the cost of reproduction and dissemination, no government copyright, and no restrictions on exploitation and reuse. ${ }^{26}$ This indicates that the role of FOI legislation in promoting reuse of government information will be limited if it does not encourage extensive access ${ }^{27}$ or largely promote proactive disclosure. ${ }^{28}$ The role of FOI legislation will be further constrained if other efficient mechanisms provided under other laws are lacking. In the US, the Copyright Act

22 Greg Terrill, 'Individualism and Freedom of Information Legislation' (2000) 87 Freedom of Information Review 30, 31; Finn observes that the current commercial-in-confidence exemption is overprotected as Australia's FOI legislation only mandates a test of causing individual disadvantage, rather than inhibiting the competition process. See Chris Finn, 'Rethinking Commercial Confidentiality in the Decade of Competition Policy' (2003) 106 Freedom of Information Review 60, 66.

23 Commonwealth, Parliamentary Debates, House of Representatives, 2 April 1981, 1059 (Senator Durack, the Attorney-General of Western Australia).

24 McLeod, above n 18.

25 Ibid.

26 Yvo Volman, 'Exploitation of Public Sector Information in the Context of the eEurope Action Plan' in Georg Aichholzer and Herbert Burkert (eds), Public Sector Information in the Digital Age: Between Markets, Public Management and Citizens' Rights (2004) 93, 95.

27 Ibid.

28 Gellman, above n 11, 124. 
stipulates that public sector information is not protected by copyright legislation at the federal level. ${ }^{29}$ The Paperwork Reduction Act prevents government agencies from conducting the four dissemination practices that impede reuse of public information. ${ }^{30}$ These laws have a major role in facilitating reuse of government information.

Other countries do not have similar laws that encourage reuse of government information, and this hinders commercial exploitation of information. In Australia, no specific legislation regulates reuse of government information, although reuse is allowed with the permission of the Commonwealth Copyright Administration in the Attorney-General's Department. ${ }^{31}$ Further, the charge scheme is likely to discourage businesses from using Australian FOI legislation. The Australian government may charge fees exceeding the actual cost for commercial use of government information. $^{32}$

In the EU, the economic potential of government information may be impeded by its copyright protection, cost-recovery and competition policies. ${ }^{33}$ While the EU has recognised the economic potential of government information, it has only partially

29 Copyright Act, 17 USC $§ 105$ (1994).

30 These four dissemination practices are: 1. establishing an exclusive, restricted, or other distribution arrangement that interferes with timely and equitable availability of public information to the public; 2. restricting or regulating the use, resale, or redissemination of public information by the public; 3 . charging fees or royalties for resale or redissemination of public information; and 4. establishing user fees for public information that exceed the cost of dissemination. Paperwork Reduction Act 44 USC $\S 3506$ (d) (4) (1995).

31 The UK Advisory Panel on Public Sector Information, Public Sector Information Policy in Australia (2006) <http://www.appsi.gov.uk/reports/policy-australia.pdf> at 5 January 2008.

32 The Australian Attorney-General's Department states that '[a]s a general principle, no fees are charged where the reproduced material is being provided free-of-charge to the public. Where permission is sought to use Commonwealth copyright material for advertising or commercial purposes to generate a financial return, the Commonwealth may set an appropriate payment or requires an equitable share of the revenue. Additional service fees are applicable for the commercial use of the Commonwealth added value, for example the typesetting, graphic design or electronic formatting, which provides savings in cost and time'. See The Australian Attorney= General's Department, Commonwealth Copyright (2006) < http://www.ag.gov.au/www/agd/agd.ns f/Page/Copyright_CommonwealthCopyrightAdministration_Commonwealthcopyright $>$ at 4 May 2008.

33 Peter Weiss, 'Borders in Cyberspace: Conflicting Public Sector Information Policies and Their Economic Impacts' in Georg Aichholzer and Herbert Burket (eds), Public Sector Information in the Digital Age. Between Markets, Public Management and Citizens' Rights (2004) 137, 138. 
relaxed these restrictions. The EU issued a directive to facilitate reuse.$^{34}$ However, the role of this directive is limited because it adopts a cost-recovery approach ${ }^{35}$ that allows public bodies to charge fees, which may cover the cost of providing information and a reasonable return on investment. In addition, reuse of government information could be further constrained because this directive permits public bodies to impose conditions on reuse.

China's legal system does not facilitate reuse of government information. In order to close these loopholes, Zhou and others designed a clause in their draft FOI Regulations to prevent any restriction on reuse of government information. ${ }^{36}$ In 2006 , the State Council's legislative plan showed that one purpose of introducing FOI Regulations was for the exploitation of government information. ${ }^{37}$ Law reformers had a high expectation of FOI legislation to facilitate reuse of government information, but the final FOI Regulations did not meet their expectations. This means that the informatisation agencies partly failed to promote FOI from the perspective of informatisation development. Therefore, the economic growth motive for FOI reform in China has been overstated and should be accorded a secondary role. This secondary role can also be confirmed due to the initial tactic of making FOI research politically acceptable, as discussed below.

\subsubsection{Economic growth as a tool for making FOI research politically acceptable}

The economic growth motive for FOI reform in China is more complex than it appears on the surface. The current literature neglects the origin of the first influential FOI research in China, and underestimates the impact of the political sensitivity of FOI before the early 2000s. The introduction of FOI legislation was initially a response to the modification of China's Law on the Protection of State Secrets 1988.

34 Directive (EC) No 98/2003 of 17 November 2003 on the Re-use of Public Sector Information [2003] OJ L 345/90.

35 Weiss, above $\mathrm{n} 33$.

36 Zhou, above n 10, 57.

37 The Notice on Suggestions for Enforcing 2006's Legislation Work and 2006's Legislative Plan No 2 [2006] of the General Office of the State Council. 
The normative view (see 6.1.1) does not describe this part of the historical background to China's FOI.

\section{FOI as a response to the revision of the Law on the Protection of State Secrets}

FOI originally came to the attention of Chinese academics and government officials due to the revision of the Law on the Protection of State Secrets. ${ }^{38}$ This historical background has been insufficiently recognised. The State Secrecy Bureau acknowledged the positive role of FOI in enhancing the classification system. ${ }^{39}$ It realised that the outdated Law on the Protection of State Secrets encouraged government officials to classify too many unnecessary state secrets, posing a risk to crucial state secrets due to scarce resources of maintaining secrecy. ${ }^{40}$ Therefore, it is unsurprising that "documents labelled "absolutely secret" can be found in university libraries in the United States' ${ }^{41}$ In view of the inefficiency and ineffectiveness of the current classification system, the State Secrecy Bureau sought consultants to assist in modifying the Law on the Protection of State Secrets. ${ }^{42}$ Professor Hanhua Zhou became one of the consultants after he was told that the revision of this Law would include consideration of the relationship between maintaining secrecy and disclosing information. ${ }^{43}$ Since then, he has continually showed interest in FOI. The

38 Hanhua Zhou, Government Governance and Administrative Law (in Chinese) ( ${ }^{\text {st }}$ ed, 2007) Preface.

39 Hanhua Zhou, 'The Legislative History of FOI Regulations in China' (in Chinese) (2008) 7 EGovernment 15, 16.

40 Ibid.

41 Jasper Becker, 'Comrade Jiang Zemin Does Indeed Seem a Proper Choice' London Review of Books (London) 24 May 2001, 12; Darch and Underwood, above n 1, 175.

42 Zhou, above $n 39$.

43 Zhou recalled that in 1997, he was honoured to be invited by the State Secrecy Bureau to take part in the work of revising the Law on the Protection of State Secrets. He refused this invitation at first for fear that he would become privy to state secrets. Jianwen Zong, a deputy director working in the State Secrecy Bureau, explained to Zhou that the Bureau was only engaged in legislation, and did not involve any state secrets. More importantly, Zong mentioned that the revision of the Law on the Protection of State Secrets would include consideration of the relationship between maintaining secrecy and disclosing information, and said that administrative law scholars should have more interest in information disclosure. Zong's persistence persuaded Zhou, and he decided to involve himself in this revision work. His research visit to Oslo University in Norway in late 1998 was the beginning of his FOI research and the introduction of the idea of FOI into China. See Zhou, above $\mathrm{n} 38$. 
involvement of law academics in the revision of the Law on the Protection of State Secrets presented an opportunity for Chinese scholars to do FOI research in China.

\section{Economic growth as an initial tactic to make FOI research politically acceptable}

While the involvement in the revision work of the Law on the Protection of State Secrets encouraged some Chinese academics to do FOI research, the topic remained politically sensitive in the late $1990 \mathrm{~s}^{44}$ Zhou found that many citizens knew little about FOI, and media outlets reported little about this issue at that time. ${ }^{45}$ Under such circumstances, any FOI research project would need to seek a way to be politically acceptable at first. Zhou was not an exception. He and other researchers conducted the first FOI research project in China under the auspices of the Law Institute of the Chinese Academy of Social Sciences in 1999. This project was initiated to help the State Secrecy Bureau complete one of its desirable targets: improving the efficiency of the maintenance of secrecy through the promotion of transparency work. ${ }^{46}$ This task, however, conflicted with its core function, preservation of state secrets. ${ }^{47}$

However, Zhou and his research team found their research difficult as they recognised that FOI was a politically sensitive issue at that time. Hence, they called their FOI research project 'Exploitation, Use and Management of Government Information Resources', ${ }^{48}$ and sought to link FOI legislation with economic growth. When the development of informatisation was widely accepted by the Chinese government in the late 1990s, Zhou and others took the next step of connecting FOI legislation with informatisation development. This tactic reflected the reality at that

44 Hanhua Zhou, 'Significance and Features of Introducing FOI Legislation in China' (in Chinese) (2007) 6 China Today Forum 29, 29.

45 Ibid.

46 Some will raise the question, 'how is it possible to improve secrecy through transparency?' Given the fact that a myriad of general documents have been classified into state secrets and there are scarce resources for the maintenance of state secrets, it is reasonable to say that increasing transparency can assist in utilising the scarce resources more effectively and efficiently. See Zhou, above $\mathrm{n} 39$.

47 Ibid. Zhou indicated that he could do FOI research and share research results with the State Secrecy Bureau.

48 Yijun Wang, 'The Breakthrough of Legislating on FOI after a Decade' (in Chinese) China Youth Daily (Beijing) 25 April 2007, 3. 
time in China and made the research project politically acceptable. It demonstrates that the role of informatisation development in improving flow of information, even economically valuable information in China was indirect.

\section{Further dividends reaped by the initial tactic}

The initial tactic that made FOI research politically acceptable reaped further dividends. The Leading Group on National Informatisation (LGNI), China's highest level informatisation agency, ${ }^{49}$ held a series of symposia in order to select experts for the coming Advisory Committee for State Informatisation, the think tank of the LGNI. Zhou was invited to deliver a speech at one such symposium in January $2002 .^{50}$ His speech focused mainly on the relationship between informatisation and FOI legislation, which attracted the attention of Jinlian Wu, a strong advocator of the new mode of economic growth and the deputy director of the Advisory Committee for State Informatisation. ${ }^{51}$ Hence, Wu recommended Zhou for membership of the future Advisory Committee. ${ }^{52}$ As a result, Zhou was recruited to the Advisory Committee in early 2002 . He was one of the few members with a legal background. ${ }^{53}$ This platform provided him an opportunity for consultation on policies and laws in relation to national informatisation. His appointment strengthened the linkage between FOI and informatisation. Zhou's efforts convinced the State Council Informatisation Office (SCIO) and LGNI, the national informatisation agencies, of the strong connection between FOI and informatisation development. Therefore, it is

49 In December 1999, the Leading Group on National Informatisation was formed, with the former Vice Premier Bangguo Wu as the head. To further strengthen this leadership, former Premier Rongji Zhu became the head of the Leading Group of National Informatisation in August 2001, and Premier Jiabao Wen has been the head since 2003. The State Council Informatisation Office was also established as the General Office of the Leading Group. See A Historical Overview of Development of Informatisation in China (in Chinese) (2007) E-Government Research <http://egov.nsa.gov.cn/digest.asp?articleid=335> at 5 April 2008; A Chronicle of Significant Events in Government Informatisation (in Chinese) (2003) China Net <http://www.china.com.cn/chinese/ zhuanti/283818.htm $>$ at 19 May 2008.

50 Zhou, above $\mathrm{n} 38$.

$51 \quad \mathrm{Wu}$, above $\mathrm{n} 7$.

52 Zhou, above $\mathrm{n} 38$.

s3 The Advisory Committee for State Informatisation has been reorganised three times. Zhou has kept his membership since 2001. See http://www.acsi.gov.cn/web/index.asp. 
not surprising that the SCIO and LGNI invigorated legislation of FOI, and promoted this work in China after 2002. ${ }^{54}$

The LGNI published the Guidance on Building E-Government in July $2002 .{ }^{55}$ The Guidance first called for the adoption of FOI legislation that was considered as a part of the legislative plan for building e-government. ${ }^{56}$ Zhou participated in the process of drafting this document, and advised on it. ${ }^{57}$ To implement the Guidance, the SCIO commissioned Zhou and his colleagues to draft FOI Regulations in May 2002. ${ }^{58}$ Zhou's position and research background facilitated his involvement in the legislative process of FOI in China. This suggests that FOI in China was more a consequence of policy entrepreneurship ${ }^{59}$ and the advocacy of key individuals than a natural outcome of the recent economic growth initiative and the move toward informatisation development.

The political acceptability of the introduction of FOI legislation increased further by the accession of China to the WTO in 2001. Chinese reformers took the WTO transparency obligations ${ }^{60}$ seriously, and used them as a tool for adding impetus to promote FOI. ${ }^{61}$ The SCIO states that the legislation of FOI was necessary to extend

54 Explanation Memorandum, above n 8, 22.

55 The Guidance on Building E-Government No 17 [2002] of the General Office of the CPC Central Committee.

56 Ibid.

57 Hanhua Zhou, 'The Legislative History of FOI Regulations in China' (in Chinese) (Speech delivered at the Second Summit on E-Government, Beijing, 28 June 2007).

58 Explanation Memorandum, above $\mathrm{n} 8,23$.

59 For more information about entrepreneurship policy, see David Hart, 'Entrepreneurship Policy: What It Is and Where It Came from' in David Hart (ed), The Emergence of Entrepreneurship Policy: Governance, Start-ups, and Growth in the U.S. Knowledge Economy (2003) 3, 3-19.

60 In China's WTO access protocol, China agreed that 'laws, regulations and other measures pertaining to or affecting trade' could only be enforced after they had been 'published and readily available to other WTO Members, individuals and enterprises'; an official journal should be established or designated for 'the publication of all laws, regulations and other measures pertaining to or affecting trade'; an enquiry point should be established or designated for facilitating access to the disclosed information from any individual, enterprise or WTO Member; and replies to application for this information should be provided in strict timeframes. See World Trade Organisation, Protocol on the Accession of the People's Republic of China, (WT/L/432) 23 November 2001, Part I, C (1).

61 Jamie Horsley, 'Toward a More Open China?' in Florini Ann (ed), The Right to Know: Transparency for an Open World (2007) 54, 62; Zhou, above n 10, 26; Heng Liu, FOI Legal Systems (in Chinese) $\left(1^{\text {st }}\right.$ ed, 2004) 16; Mingjie Zhang, Open Government: Research on FOI Laws (in Chinese) (1 $\left.1^{\text {st }} \mathrm{ed}, 2003\right) 208$. 
China's reform and opening up policy (Gaige Kaifang) that commenced in 1978, and was a measure to cherish and extend the achievement of 15 years of tough WTO accession negotiations. ${ }^{62}$ The WTO transparency requirements directly influenced the city of Guangzhou, a Chinese economic hub, to adopt its FOI legislation. ${ }^{63}$ The WTO transparency requirements were another economic factor that helped diminish the political sensitivity of FOI in the early 2000 s, although the WTO has only required China to proactively disclose laws and policies related to trade.

\subsection{Reassessing anti-corruption efforts as a rationale for FOI}

Alongside economic growth, anti-corruption efforts are seen by some academics as a key driving force for the adoption of FOI legislation in many countries, including China. ${ }^{64}$ Many Chinese and non-Chinese academics have rationalised China's FOI phenomenon from this perspective. ${ }^{65}$ Mendel agrees with Sutton and Holsen that the motive for FOI reform in China is to counter the growing threat of corruption undermining their remarkable economic growth' ${ }^{66}$ The current literature focuses on the role of FOI in exposing, rather than preventing corruption in China ${ }^{67}$ However, it was the shift of focus on corruption prevention that added impetus to accept FOI in China. Furthermore, close scrutiny of the historical background to the introduction of FOI reveals that the link between the fight against corruption and FOI appeared late, and the access mechanism was not considered as a primary tool for combating corruption. Thus, the contribution of the anti-corruption initiatives to the adoption of FOI legislation has also arguably been overstated.

62 Explanation Memorandum, above n 8, 18.

63 Liu, above n 61, 237.

64 Alasdair Roberts, Blacked out: Government Secrecy in the Information Age (1 $\left.{ }^{\text {st }} \mathrm{ed}, 2006\right) 110$.

65 Zhengqun Zhao, 'Discussion of Anti-Corruption through Openness in Government Affairs' (in Chinese) (2001) 6 Theory and Modernisation, 51, 54; Roberts, above n 64; Horsley, above n 1; Blanton, above $\mathrm{n} 3$.

66 Mendel, above n 5; Sutton and Holsen, above $\mathrm{n} 5$.

67 Roberts agrees with an analyst that FOI legislation in China is used to enlist 'ordinary people to serve as watchdogs on behalf of the centre'. See Alasdair Roberts, Freedom of Information: From Millions to Billions (2008) Sunshine Week <http://www.sunshineweek.org/sunshineweek/roberts0 $8>$ at 2 October 2008. 


\subsubsection{The shift from fighting corruption to preventing corruption}

The Communist Party of China (CPC) acknowledged the existence of corruption in China in 1982. Whilst this left open the possibility of undertaking transparency reform, no such action took place before 1987. The fight against corruption has become a recurring theme of public policy in China since $1982 .{ }^{68}$ The CPC first recognised the existence of corruption at its $12^{\text {th }}$ National Congress of the CPC (NCCPC). ${ }^{69}$ The political report of the $16^{\text {th }}$ NCCPC took the fight against corruption as a major political task. ${ }^{70}$ Therefore, contrary to dissidents' criticism that anticorruption trials have been used as a tool primarily for 'faction fights', ${ }^{71}$ the CPC has taken the fight against corruption seriously since 1982 . What needs to be ascertained is to what degree transparency reform has been given a role in this fight. The work of Stiglitz suggests that information asymmetries are key contributors to the high level of corruption in China. ${ }^{72}$ The Central Commission for Discipline Inspection (CCDI), a key anti-corruption agency, has persisted in promoting Openness in Government Affairs (OGA) to combat corruption since the $13^{\text {th }}$ NCCPC held in $1987 .{ }^{73}$ Since then, the work of OGA has always accompanied China's anti-corruption initiatives.

However, it was only the shift of focus on corruption prevention that laid a foundation for the consideration of FOI legislation. ${ }^{74}$ While the last three decades of anti-corruption efforts have achieved a certain degree of success, the fight against corruption still requires the Chinese government to continue its efforts, and also

68 Ziyang Zhao, 'Take Strides along the Road to Socialism with Chinese Characteristics' (in Chinese) (Speech delivered at the $13^{\text {th }}$ National Congress of the CPC, Beijing, 25 October 1987); Zemin Jiang, 'Accelerate Strides toward Reform and Opening up and Modernism, Strive for Greater Victories in Building Socialism with Chinese Characteristics' (in Chinese) (Speech delivered at the $14^{\text {th }}$ National Congress of the CPC, Beijing, 12 October 1992).

69 Yaobang $\mathrm{Hu}$, 'Comprehensively Create a New Situation in Building Socialism with Chinese Characteristics' (in Chinese) (Speech delivered at the $12^{\text {th }}$ National Congress of the CPC, Beijing, 1 September 1982).

70 Jiang, above $n 7$.

71 Au Loong-Yu, 'Alter-Globo in Hong Kong' (2006) 42 New Left Review 117,125.

72 Joseph Stiglitz, 'Transparency in Government' in the World Bank (ed), The Right to Tell: The Role of Mass Media in Economic Development (2002) 27, 35.

73 The National Congress of the CPC called on leading agencies to improve the openness of their activities, and let the people know about and discuss important matters (see 7.1.1). See Zhao, above $\mathrm{n} 68$.

74 Zhang, above n 61, 207; Zhou, above n 10, 26. 
transform and improve its methods of fighting corruption by placing equal importance on corruption prevention and corruption punishment. The CPC first decided to focus on corruption prevention at its $16^{\text {th }}$ NCCPC held in $2002 .{ }^{75}$ From that date, the Chinese government has shown its determination to fight corruption from the source. It adopted measures to strengthen corruption prevention, including signing the United Nation's Convention against Corruption in $2003,{ }^{76}$ issuing an outline to establish and improve its corruption punishment and prevention system in 2005, ${ }^{77}$ and establishing the National Corruption Prevention Bureau directly accountable to the State Council in $2007 .{ }^{78}$ One division of the Bureau is responsible for OGA and FOI matters as well as other openness affairs. ${ }^{79}$ This shift to corruption prevention in China after the early 2000 s increased the utility of FOI.

\subsubsection{FOI and corruption prevention}

FOI, as a measure to prevent corruption, has achieved this status for two key reasons. First, FOI is a cost-effective measure compared with the high economic losses stemming from corruption. According to $\mathrm{Hu}$, these losses accounted for 'an annual average of $14.5-14.9 \%{ }^{80}$ of Gross Domestic Product between 1999 and 2001. This indicates that roughly 1.4 trillion yuan (about \$US175 billion) was consumed by corruption in each of those years. The likely implementation cost of FOI is dwarfed by this figure. FOI is also cost effective because it can reduce the chance or scope for corruption, saving the costs of punishing corrupt officials and improving the

75 Jiang, above $\mathrm{n} 7$.

76 The Chinese Government Signed the United Nations Convention against Corruption and Put up Four Recommendations (in Chinese) (2003) Xinhua Net <http://news.xinhuanet.com/world/200312/11/content_1224815.htm > at 5 April 2008.

77 The Notice on Enforcement Outline for the Establishment and Improvement of a Corruption Punishing and Prevention System with Equal Attention Paid to Education, Institutions and Supervision No 3 [2005] of the Central Committee of the CPC.

78 The National Corruption Prevention Bureau Established: Speech by the First Head Ma Wen (in Chinese) (2007) China News <http://www.chinanews.com.cn/gn/news/2007/09-13/1025663.shtm l> at 13 September 2007.

79 The National Corruption Prevention Bureau, Departments and Responsibilities of the National Corruption Prevention Bureau (in Chinese) (2007) <http://yfj.mos.gov.cn/yfj/news.jsp?mid=2007 $1109026298>$ at 5 February 2008.

80 Angang $\mathrm{Hu}$, 'Public Exposure of Economic Losses Resulting from Corruption' (2002) 4 China \& World Economy 44, 44. 
efficiency of allocating scarce anti-corruption resources. Therefore, compared with other countries, the Chinese government expressed little concern about the inappropriate cost of administration of FOI legislation. ${ }^{81}$

Second, FOI is regarded as a method to prevent corruption at the source. ${ }^{82}$ This point is illustrated by the central government's willingness to rely on FOI legislation to disclose beneficial policies, including those for improving farmers' income or reducing farmers' burden, more effectively. Ou argues that there are many beneficial policies in China, but they are not well known to the masses ${ }^{83}$ due to local government officials' secretive work styles. A disadvantage is that these styles have been used to serve 'selfish purposes', ${ }^{84}$ which has created unnecessary information asymmetries between local government agencies and the masses. Two examples have been used to illustrate the necessity to make disclosure of beneficial policies more effective. One was the classification of the central government's document about the increase of farmers' income. ${ }^{85}$ Another was the prohibition of disclosing a booklet combining the central government's policies of reducing farmers' burden. ${ }^{86}$ Zhou

81 Explanation Memorandum, above $\mathrm{n} 8,15$. Zhou argues that the establishment of an access regime in China would be cheap. See Zhou, above $\mathrm{n} 10,23$. This is different from other countries, such as Australia and Germany. The affordability of this expensive mechanism is a major concern in these two countries. See The Australian Senate Standing Committee on Constitutional and Legal Affairs, Parliament of the Commonwealth of Australia, Freedom of Information (1979) [6.5-6.25]; Brian Candler, 'The Australian Freedom of Information Act: A Personal View' in Robert Gregory (ed), The Official Information Act: A Beginning (1984) 16, 24; Herbert Kubicek, 'Third-Generation Freedom of Information in the Context of E-Government: The Case of Bremen, Germany' in Georg Aichholzer and Herbert Burkert (eds), Public Sector Information in the Digital Age: Between Markets, Public Management and Citizens' Rights (2004) 275, 275.

82 Zhou, above n 10, 26; Qiong Zhang, 'The Legislative Affairs of the State Council Introduces FOI Regulations' (Press Release, 24 April 2007).

83 Yangwu Ou, Speech delivered at Seminar on the FOI Regulations, Beijing, 17 March 2007. See http://www.hongfan.org.cn/file/upload/2007/03/17/1215097825.pdf.

84 Hanhua Zhou, 'Open Government in China: Practice and Problems' in Ann Florini (ed), The Right to Know: Transparency for an Open World (2007) 92, 106.

85 In 2005, an official in Hunan Province recalled that he had difficulty in photocopying a central government document, titled 'Opinions of the CPC Central Committee and the State Council concerning Some Policies on Promoting the Increase of Farmers' Income', for a friend. This document was marked with the label, confidential, the lowest secrecy level set out in the Law on the Protection of State Secrets 1988. See Changping Luo and Jie Feng, 'The Classification System Rectified' (in Chinese) The Beijing News (Beijing) 20 September 2005, A22-23.

86 In 2000, the Editorial Department of the Commentaries for Rural Development published a booklet, titled 'The Work Manual on Reducing Farmers' Burden', used to assist farmers to familiarise themselves with the central policy documents. There were 12,000 copies were sold to 
stated that '[w]hat is most inconceivable is that the booklet is in no sense an illegal publication, only a compilation of the Party's rural policies'. ${ }^{87}$

FOI legislation is a mechanism that not only requires government agencies to actively release beneficial policies, but authorises citizens to pressure the government to disclose these policies via access requests. FOI legislation can reduce local government officials' excessive control over many beneficial policies, aiding the central government in reducing scope for government officials to be corrupt and abusive and in saving anti-corruption resources. As Deng argues, 'if [organisational and working systems] are unsound, they may hamper the efforts of good people or indeed, in certain cases, may push them in the wrong direction' ${ }^{88}$ FOI legislation is a sound system, which provides the central government with a mechanism to allow greater scrutiny and transparency of lower levels of government.

The view of FOI as a tool for preventing corruption assisted FOI reform in China to gain strength and credibility. The likelihood that FOI legislation would be adopted was accordingly increased.

\subsubsection{Reappraisal of the role of FOI as a tool for combating corruption}

The current literature has overstated the anti-corruption element of the development of FOI for the following two reasons. First, the historical background to the introduction of FOI legislation shows that the link between the anti-corruption initiatives and FOI appeared late in the lead up to the first national FOI legislation in early 2007. FOI reform, an integral part of transparency reform, was promoted by Chinese anti-corruption agencies much later than other transparency practices,

\footnotetext{
farmers within Jiangxi Province in two weeks, but the Editorial Department was then prevented from selling this booklet. The copies of the booklet that had already been sold were recalled through various methods. The recalling agencies adopted the slogan that 'the adverse effects must be eliminated wherever the copies of the booklet are sold'. See China Central Television, 'The Booklet on the Reduction of the Farmers' Burden Was Forbidden to Be Distributed in Jiangxi Province' The 30 Minutes ' Economics, 11 November $2000<\mathrm{http} / / / \mathrm{www} . c \mathrm{ctv} . c 0 m /$ financial/jingji/ sanji/zhoume/0102_22/z22_17.html>at 22 March 2008.

87 Zhou, above $\mathrm{n} 84,113$.

88 Xiaoping Deng, Selected Works of Xiaoping Deng (Volume II) (in Chinese) (2 $\left.2^{\text {nd }} \mathrm{ed}, 1994\right) 333$.
} 
especially OGA, which was used to fight corruption after $1987 .{ }^{89}$ Though it might have seemed likely that anti-corruption agencies would have promoted FOI legislation earlier than other agencies, they did not ally themselves with the informatisation agencies to promote FOI legislation in China before 2004.

The political sensitivity of FOI may have hindered anti-corruption agencies from giving sufficient attention to FOI. After the issue of the Implementation Outline for Pushing Forward Administration by Law in an All-Round Way in March $2004,{ }^{90}$ the CCDI and the Leading Group on National Openness in Government Affairs (LGNOGA) began to address the importance of FOI in corruption prevention. ${ }^{91}$ Thereafter the anti-corruption agencies advocated legislation of FOI. So it was not until 2004, when the central government called for the introduction of FOI legislation, that the anti-corruption link accepted by the CCDI and LGNOGA, the national primary supervisory agencies. This process reduced the anti-corruption aspect of the FOI story in China.

Second, the access mechanism, which lies at the core of FOI legislation, was not promoted as a primary tool for combating corruption. Anti-corruption agencies did not promote FOI from this core concept. This created a paradox whereby FOI was regarded as a tool for exposing corruption after the fact. ${ }^{92}$ The CCDI and LGNOGA were keen to advocate FOI primarily for institutionalising OGA promoted by them for over two decades. Yong He, the Deputy Secretary of CCDI, considers that FOI Regulations are the basic legislation in relation to OGA, and that they can play a key role in gradually institutionalising OGA in China. ${ }^{93}$ Qin recalled that the LGNOGA

89 The General Office of the Central Commission for Discipline Inspection, Openness in Government Affairs ( $1^{\text {st }}$ ed, 2004) 6-17.

90 The Implementation Outline for Pushing Forward Administration by Law in an All-Round Way No 10 [2004] of the General Office of the State Council.

91 Yong He, 'The Speech of Yong He at the Second Meeting of the Leading Group on National Openness in Government Affairs' (Speech delivered at Beijing, 29 April 2004).

92 Roberts, above $\mathrm{n}$ 64, 110; Roberts, above $\mathrm{n} 67$.

93 Yong He, 'The Speech of Yong He at the Seventh Meeting of the Leading Group on National Openness in Government Affairs', (Speech delivered at Beijing, 21 March 2007). 
had considered the institutionalisation of OGA for many years. ${ }^{94}$ This indicates that OGA, which focused on proactive disclosure rather than the access mechanism featuring dominantly in FOI legislation, was recognised by anti-corruption agencies as a direct tool for combating corruption. This coincided with the concern over the effectiveness of the access mechanism as an anti-corruption tool. ${ }^{95}$

\subsection{Conclusion}

This chapter argues that the roles of economic growth and anti-corruption in the process of Chinese FOI reform were overstated, although they were important. Other factors, including social, political and legal ones discussed in Chapters 3, 4 and 5 are largely unexplored, but more crucial and direct than economic growth and anticorruption rationales for the acceptance of FOI in China. Furthermore, the historical background to the introduction of FOI shows that informatisation was used as a means of making FOI reform more politically acceptable, rather than as a primary driving force of FOI reform. The link between the fight against corruption and FOI appeared late, and the access mechanism was not considered as a primary tool for exposing corruption.

This chapter and the previous three chapters have contributed to an exploration of the origins of FOI reform in China. The next chapter explores China's gradual legislative process for FOI.

94 Hai Qin, Speech delivered at Seminar on the FOI Regulations, Beijing, 17 March 2007. See http://www.hongfan.org.cn/file/upload/2007/03/17/1215097825.pdf.

95 Roberts argues that the effectiveness of the access mechanism as an anti-corruption tool is 'largely unknown'. Roberts, above n 64, 121; Mendel points out that 'the right to information is [not] a strategy for exposing individual acts of wrongdoing'. See Mendel, above $\mathrm{n} 5$. Their concern has been partly demonstrated in practice. Cheng observes that there was no FOI case connected with the fight against corruption in the process of implementing local FOI Rules in China. See Jie Cheng, 'Investigation Report on Implementation of Sub-National FOI Rules: What Can We Expect Now That FOI Regulations Are in Effect?' (in Chinese) Legal Daily (Beijing) 11 May 2008, 3; Bookman and Guerrero Amparan argue that 'the impact of transparency and the right to know on corruption has been unimpressive' in Mexico. See Zachary Bookman and Juan-Pablo Guerrero Amparan, 'Two Steps forward, One Step Back: Assessing the Implementation of Mexico's Freedom of Information Act' (2009) 1 Mexican Law Review 3, 49. 


\section{7: GRADUAL LEGISLATIVE PROCESS FOR FOI IN CHINA}

\subsection{Introduction}

This chapter explores the process of gradual legislative reforms leading up to the introduction of FOI legislation in China. It shows that FOI Regulations were a key but interim result of many increments, such as openness in village and government affairs, and FOI rule-making activities at both city and province levels. All these increments, which were connected with the multiple geneses discussed in previous four chapters, helped increase information flow in the Chinese information environment. This therefore gradually enhanced the capacity to adopt the first national FOI legislation - FOI Regulations. Yet there is a paradox. On an initial survey, many inside and outside of China were caught by surprise at the apparent rapidity of Chinese FOI reform. Compared with most other countries, China experienced less internal resistance to FOI reform (see 1.2.5), and this was possible to enable the speedy introduction of FOI legislation. However, evidence suggests that the reform was part of a broad strategy of gradualism, to which the Chinese government adhered after the reform and opening up policy that commenced in 1978 (see 1.2.6).

This chapter has three sections. Section one explores the role of Openness in Government Affairs (OGA) in preparing for considering FOI legislation. The second section examines the role of sub-national FOI rule-making activities in serving as tests for national FOI legislation. Section three examines the legislative process for FOI at the national level. 


\subsection{Openness in Government Affairs: a firm basis for FOI legislation}

Experiments in and institutionalisation of OGA primarily for a long term democratisation process (see 4.2 and 4.3) provided a solid foundation for the consideration of FOI legislation in China. The practices of OGA in China were first initiated by a project dealing with Openness in Two Areas and Supervision by the Public (OTASP) that commenced in the late 1980s. ${ }^{1}$ After a decade's experimentation, OGA was formally extended to all township government agencies in $2000 .^{2}$ Five years later, OGA was officially permitted to be extended to all levels of government. $^{3}$

\subsubsection{The project dealing with Openness in Two Areas and Supervision by the Public}

The Communist Party of China (CPC) first formally recognised the importance of openness in 1987 through the OTASP project, ${ }^{4}$ which presented a limited opportunity for the development of OGA. The political report of the $13^{\text {th }}$ National Congress of the CPC (NCCPC) in 1987 called on leading agencies to improve the openness of their activities and let the people know about and discuss important matters. ${ }^{5}$ The OTASP project responded to the call of the $13^{\text {th }}$ NCCPC to take strong action to curb corruption. ${ }^{6}$ It included disclosure of rules and results concerning the process of administrative affairs, and acceptance of supervision from the public. ${ }^{7}$ It was launched in Hebei Province in 1988, and shortly thereafter expanded to other

1 Ziyang Zhao, 'Take Strides along the Road to Socialism with Chinese Characteristics' (in Chinese) (Speech delivered at the $13^{\text {th }}$ National Congress of the CPC, Beijing, 25 October 1987).

2 The Notice on Promoting Openness in Government Affairs around All Government Agencies at the Township Level No 25 [2000] of the General Office of the CPC Central Committee.

3 The Notice on Further Promoting Openness in Government Affairs No 12 [2005] of the General Office of the CPC Central Committee.

Zhao, above $\mathrm{n} 1$.

5 Ibid.

6 The General Office of the Central Commission for Discipline Inspection, Openness in Government Affairs ( $1^{\text {st }}$ ed, 2004) 7.

7 Ibid. 
provinces, including Hunan and Fujian. ${ }^{8}$

While the scope of the OTASP was limited, it began the process of flow of government information in China. It also helped the Chinese government recognise the benefits of openness, including the facilitation of the fight against corruption. ${ }^{9}$

\subsubsection{Openness in Government Affairs at the primary level}

The OTASP project was extended to OGA at the primary level. However, the latter was not the direct result of implementation of this project, but the result of Openness in Village Affairs (OVA) (see 4.2.1). The Notice on Comprehensively Implementing Openness in Village Affairs and Democratic Management, issued in 1998, encouraged, rather than required township governments to practice OGA during the period of implementing OVA. ${ }^{10}$ OGA at the primary level was formally supported by the central government in 2000 by the Notice on Promoting Openness in Government Affairs around All Government Agencies at the Township Level. ${ }^{11}$ After several years' practice, OGA at the primary level was standardised in $2004 .{ }^{12}$ Its standardisation and expansion at the township level prepared the ground for OGA at a higher level.

OGA at the township level revealed the relaxation of the secretive Chinese information environment. It provided a catalyst for developing grassroots democracy (see 4.2.2), apart from assisting the fight against corruption. These considerations gave force to OGA in China, increasing the prospects of greater transparency.

12 The General Office of the Central Commission for Discipline Inspection, above $\mathrm{n} 6,16$.
} 


\subsubsection{Openness in Government Affairs at and above the county level}

OGA at higher levels of government increased the possibility and capability for the acceptance of FOI in China. During the period when OGA operated at the township level, some government agencies at and above the county level began disclosing information concerning their administrative affairs. ${ }^{13}$ To respond to the call of the $16^{\text {th }}$ NCCPC that required government agencies to disclose their affairs, ${ }^{14}$ more local governments and state agencies began to undertake and institutionalise openness practices. These openness efforts improved information flow in the Chinese information environment, and with them increased China's capacity to support FOI.

\section{Institutionalisation of OGA by ministries}

Several ministries began to legislate on their openness practices in the early 2000s. In 2003 the Ministry of Commerce institutionalised its OGA, though its scope was limited to the Ministry level rather than the administrative system across the country. The Ministry of Transport followed suit, adopting its Interim Rules on Openness in Government Affairs in 2004 to standardise information dissemination among transportation agencies. It prepared the ground for other ministries, such as the Ministries of Personnel, Labor and Social Securities, and Water Resources, to legislate on their OGA practices.

\section{Institutionalisation of OGA by provincial and city governments}

The institutionalisation of OGA was not limited to ministries. Chinese sub-national governments conducted similar rule-making activities. The Fujian government was the first provincial government to legislate on its OGA in 2001. Guangdong Province became the first province to adopt local OGA regulations in $2005,{ }^{15}$ elevating the status of OGA in this province. Sichuan Province followed suit in 2006. Some major

13 Ibid 11.

14 Zemin Jiang, 'Build a Well-off Society in an All-Round Way and Create a New Situation in Building Socialism with Chinese Characteristics' (in Chinese) (Speech delivered at the $16^{\text {th }}$ National Congress of the CPC, Beijing, 8 November 2002).

15 Local regulations, which are passed by the local people's congresses, have a higher legal status than administrative rules. 
cities, such as Harbin, Taiyuan and Shenzhen, also institutionalised their OGA. ${ }^{16}$ These rule-making activities focused on the standardisation of OGA, which provided models for the central government to consider proactive disclosure requirements under national FOI legislation.

\section{Policy initiatives by other government agencies}

Although other government agencies did not institutionalise OGA, they issued policy documents to develop openness practices. An example is the Ministry of Public Security. Openness in police affairs was first formally required under the Police Law 1995. ${ }^{17}$ The Ministry of Public Security in 1999 issued a policy document to make laws and procedures concerning their functions public. ${ }^{18}$ Other state agencies, including the State Administration for Industry and Commerce ${ }^{19}$ and the State Administration of Taxation, ${ }^{20}$ also issued policy documents to promote OGA in their own administrative systems. Whilst the Ministry of Foreign Affairs is considered a special ministry, it has exerted efforts to declassify its archives during recent years. ${ }^{21}$ A 2006 investigation found that 31 provincial governments and 36 ministerial

16 All these three cities adopted its Openness in Government Affairs Rules in 2003.

17 Article 44 under the Police Law 1995 requires that the rules and regulations formulated by the police agencies which have a direct bearing on the interests of the public shall be made known to the public.

18 The Notice on Implementing Openness in Police Affairs in All Public Securities Agencies No 43 [1999] of the Ministry of Public Security.

19 The Notice on Further Promoting Openness in Government Affairs in All Administration by Industry and Commerce Agencies No 154 [2000] of the General Office of the State Administration for Industry and Commerce.

20 The Notice on Suggestions for Further Implementing 'Eight Openness Items' concerning Civilised Tax Collection in All Tax Agencies No 144 [2000] of the State Administration of Taxation; Suggestions on Further Promoting Openness in Government Affairs No 69 [2006] of the State Administration of Taxation.

21 Article 19 of the Archives Law 1987 requires state archives centres to generally disclose archives upon the expiration of 30 years from the date of their generation. The Ministry of Foreign Affairs did not give much respect to this requirement before. However, in 2004, the Ministry established a special library for these archives and declassified its archives from between 1949 and 1955. In 2006, it declassified the archives from between 1956 and 1960, and decided to do similar work every two years. See Declassified Foreign Affairs Archives from between 1956 to 1960 Were Accessible in China (in Chinese) (2006) Xinhua Net <http://news.xinhuanet.com/banyt/200607/19/content_4852638.htm> at 29 March 2008. 
agencies adopted their own measures to implement OGA. ${ }^{22}$

\section{Central government policy initiatives}

The State Council followed this openness trend. Normative documents, ${ }^{23}$ which are frequently used to conduct administration by government agencies, were previously prohibited from being disclosed to the public. In 2002 the General Office of the State Council decided to provide free copies of the Gazette of the State Council, which includes many normative documents, to all public bodies and political parties. ${ }^{24}$ The full copies of the Gazette of the State Council are now freely distributed to the public through the web portal of China. ${ }^{25}$

The central government formally widened these proactive disclosure practices to all levels of government in $2005 .^{26}$ In this year, the State Council joined the CPC Central Committee to jointly issue the Notice on Further Promoting Openness in Government Affairs. ${ }^{27}$ The Notice required government agencies to disclose all types of information in relation to administrative management and public services unless exempted as a state secret, trade secret or individual privacy. ${ }^{28}$ It also displayed the central government's determination to introduce national FOI legislation in China, as it called for the acceleration of the formulation of FOI Regulations and encouraged local governments to adopt FOI Rules in the interim. ${ }^{29}$

22 Yanjie Li and Qin Zhang, Thirty-One Provincial Governments Adopted Rules on Openness in Government Affairs (in Chinese) (2006) Xinhua Net <http://news.xinhuanet.com/politics/2006$12 / 10 /$ content_5463360.htm> at 19 May 2008.

23 Normative documents provide rules, guidelines or characteristics for government activities.

24 Songyan Zhu, 'Analysis of and Thoughts on the Current Situation of FOI in China' (in Chinese) (2003) 3 Expanding Horizons 31, 31.

25 This website only provides access to the Gazette of the State Council published later than 1999. The website also provides a link to access gazettes of local governments. See http://www.gov.cn/gongbao/2008/issue1392.htm.

26 The Notice on Further Promoting Openness in Government Affairs, above $\mathrm{n} 3$.

27 Ibid.

28 Ibid.

29 Ibid. 


\subsection{FOI legislation: developments at the sub-national level}

China's unified and multilevel legislative system offered considerable flexibility to experiment with FOI law-making or rule-making. ${ }^{30}$ The institutionalisation of FOI was conducted at the national and local levels at the same time, but was first achieved at local and provincial levels. Sub-national FOI rule-making activities were undertaken widely with implicit and explicit support from the central government. These local legislative and implementation activities were the starting point of operating the pull aspect of information flow. They further ameliorated the Chinese information environment, thereby increasing the capacity to accommodate FOI and accelerating the introduction of national FOI legislation.

\subsubsection{FOI legislation: developments at the city level}

Chinese local governments have conducted rule-making activities related to FOI since 2002. These activities not only guaranteed the standardisation of openness practices in their administrative areas, but prepared the ground for higher levels of government to consider similar rules. In China, a comparatively larger city ${ }^{31}$ may enact local rules. ${ }^{32}$ By the end of 2006, 17 comparatively larger cities had adopted FOI Rules (Appendix 4). Among the 49 comparatively larger cities in China, Guangzhou was the first city to pass FOI legislation in China in November 2002. Eight cities introduced FOI legislation in 2004. Another five brought FOI Rules into

30 Jie Liu, The Right to Know and the FOI Act (in Chinese) (1 $1^{\text {st }}$ ed, 2005), 282. According to the Legislation Law 2000, the Constitution, which is adopted and amended by the National People's Congress, enjoys the highest level of legal authority. An act or law, which is adopted and amended by the National People's Congress or the standing committee of the National People's Congress, is at the second level of legal authority. Regulations, which are divided into administrative regulations, local regulations, autonomous regulations, and separate regulations, are at the third level of legal authority and are issued by the State Council or local people's congresses and cannot override a law. The FOI Regulations are administrative regulations, which were adopted by the State Council. Administrative rules are at the fourth level of legal authority, and are passed by state organs, provincial governments, or governments in comparatively larger cities. Many local FOI Rules, which were adopted by provincial governments and comparatively larger cities, are at this level.

31 A comparatively larger city refers to a city where a provincial or autonomous regional people's government is located or where a special economic zone is located, or a city approved as such by the State Council.

32 The Legislation Law 2000 (China) Art 73. 
their localities in 2005. Three more followed suit in 2006. Many other cities issued policy documents about FOI to boost openness in their administrative areas. ${ }^{33}$ All these rule-making activities legislated on proactive disclosure and access to information. Implementation of FOI Rules enabled the central government to learn more about the prospects for FOI legislation to conform to China's local circumstances.

However, FOI Rules were rarely used by the public. This assisted the central government to realise that there would be no high use of FOI or lawsuits flowing from FOI legislation. According to Cheng, the landmark case did not occur until 2006, when Guangzhou had adopted its FOI Rules for four years. ${ }^{34}$ Only two influential FOr lawsuits were brought in Wuhan ${ }^{35}$ and Zhengzhou respectively. ${ }^{36}$ No other significant FOI lawsuits were reported in other cities that adopted FOI Rules.

\subsubsection{FOI legislation: developments at the province level}

In China, local or sub-national experiments in FOI were used to serve as tests for national legislation. ${ }^{37}$ Local FOI legislative activities may have encouraged the central government to consider a similar national policy. This explains why the State Council Legislative Affairs Office became more active in promoting the first national FOI legislation after $2006{ }^{38}$ Twelve governments at the province level in mainland China had adopted FOI Rules by the end of 2006 . This provided a solid foundation

By the end of 2006 , about 28 cities passed their normative documents about FOI.

Jie Cheng, 'Investigation Report on Implementation of Sub-National FOI Rules: What Can We Expect Now That FOl Regulations Are in Effect?' (in Chinese) Legal Daily (Beijing) 11 May 2008, 3; Jie Cheng, 'FOI Regulations and Public Libraries' (in Chinese) (2008) 4 Information and Documentation Services 16, 17.

35 The Trial of the First FOI Case in Wuhan City Was Completed with the Judgment of the Labor Bureau Violating Wuhan FOI Interim Rules (in Chinese) (2004) The Rule of Law in Qiantan <http://www.qtfz.gov.cn:8080/show.jsp?id=3303> at 7 May 2008.

36 Donghong $\mathrm{Li}$ and Junde $\mathrm{Li}$, "Why Is There Effect of "Glass Door" happening to "Sunshine Government"' (in Chinese) Henan Daily (Shijiazhuang) 22 June 2006, 12.

37 Liu, above $\mathrm{n} 30$.

38 Hanhua Zhou, Speech delivered at Seminar on the FOI Regulations, Beijing, 17 March 2007. See http://www.hongfan.org.cn/file/upload/2007/03/17/1215097825.pdf. 
for the central government to build successful national FOI legislation in China. ${ }^{39}$ There was a rapid uptake of FOI legislation at the province level in China. Among the 31 provincial governments in mainland China, Shanghai Special Municipality published the first FOI legislation at the province level on 20 January 2004. One special municipality and two provinces brought FOI Rules into their administrative areas in 2004. Another six provinces adopted FOI Rules in 2005. In 2006, two provinces published FOI Rules (Appendix 5). Other provincial governments, such as Beijing, Guangxi and Ningxia, publicised draft FOI Rules. Zhejiang also drafted similar rules, but did not make the draft version public.

At least two aspects explain the benefits of local FOI Rules to the development of equivalent legislation on a national scale. First, these provincial governments aided the central government to understand more about the compatibility of FOI legislation with the local conditions in China, especially the Shanghai FOI Rules. The Rules provided 'the most comprehensive framework' for the central government to use as a foundation. ${ }^{40}$ More importantly, the central government scrutinised the Shanghai government's launch of 'unprecedented organisational, training and preparatory work to help ensure the effective implementation'. ${ }^{41}$ The Shanghai Legislative Affairs Office assisted the State Council Legislative Affairs Office to arrange the legislative investigation into FOI in Shanghai in $2006 .{ }^{42}$ Some staff members in the Shanghai

39 Pearlman argues that 'sub-national Freedom of Information laws ... provide perhaps the best foundation from which to build a successful national Freedom of Information regime. They are the functional equivalents of laboratory microcosms that can be moulded and adapted to fit even the most unusual political, bureaucratic, social and economic cultures in which they must operate'. See Mitchell Pearlman, The Importance of Freedom of Information at the Sub-National Level (2008) State of Connecticut <http://www.state.ct.us/FOI/Articles/Sun-National_Artic.htm> at 3 October 2008.

40 Jamie Horsley, Shanghai Advances the Cause of Open Government Information in China (2004) Freedom of Information Organisation <http://www.freedominfo.org/news/20040420.htm> at 19 September 2008 .

41 Ibid.

42 The Shanghai Legislative Affairs Office and the Shanghai Institute for Administrative Law Studies, 'Work Review for 2006 and Work Outline for 2007 of the Shanghai Legislative Affairs Office' (in Chinese) (2007) 4 The Brief Report on the Shanghai Government Rule of Law. See http://www.chinalaw.gov.cn/jsp/contentpub/browser/contentpro.jsp?contentid=co1891089252. 
Legislative Affairs Office took part in drafting the FOI Regulations. ${ }^{43}$

Second, implementation of local FOI rules assisted the central government to identify the potential problems of controversial definitions for government information, the diversity of agencies responsible for FOI work and the complexity of the fee structure for access requests. ${ }^{44}$ These diverse practices necessitated the standardisation of FOI work through the adoption of national FOI legislation. Third, provincial FOI practices may have strengthened the central government's belief that FOI legislation would not undermine other key interests, such as national security, privacy and trade secrets. ${ }^{45}$ The willingness and capability to adopt national FOI legislation thus swelled.

\subsection{FOI legislation: developments at the national level}

The central government took the adoption of FOI legislation seriously after 2004 . Informatisation agencies initiated the legislation of FOI legislation in $2002 .^{46}$ Anticorruption agencies allied themselves with this attempt after $2004{ }^{47}$ Their efforts cumulatively contributed to the adoption of the FOI Regulations in early 2007.

\subsubsection{Which to introduce first: FOI law or FOI regulations}

The Chinese government faced a choice whether to first introduce FOI law or FOI Regulations. A similar question does not arise in the common law system, where regulations are adopted after, as part of a law to provide additional detail or procedure. FOI law has advantages compared with FOI Regulations. It can create a new and enforceable access right and impose criminal sanctions against violations of

Ibid.

44 Sheng Li, 'The Background, Main Contents and Inventory Compilation concerning China's FOI Regulations' (in Chinese) (2008) 5 E-Government 21, 22.

45 Explanation Memorandum, The Draft of FOI Regulations 2002 (China) 13.

46 Ibid 23.

47 Yong He, 'The Speech of Yong He at the Second Meeting of the Leading Group on National Openness in Government Affairs' (Speech delivered at Beijing, 29 April 2004). 
disclosure requirements. ${ }^{48}$ Chinese deputies of the National People's Congress (NPC) advocated the adoption of FOI law, submitting proposals for the enactment of FOI law to the NPC seven times between 2002 and 2006 (Appendix 6). Chinese deputies desired FOI legislation, not to balance the power between the executive and parliament found in advanced liberal democracies (see 1.1.1), but for other local reasons, such as standardising local FOI legislative activities and resolving the dilemma of implementation of local FOI Rules. ${ }^{49}$

In response to the call of many deputies, the Standing Committee of the $10^{\text {th }}$ NPC in early 2003 listed FOI law in the secondary priority category of its five-year legislative plan (2003-2008). ${ }^{50}$ This meant that the FOI law would be researched, and a review process would be initiated if appropriate. ${ }^{51}$ However, this plan was not enforced, and FOI law is yet to be drafted. In March 2004, the Internal and Judicial Affairs Committee of the NPC recognised the need to adopt FOI law in China in order to supervise government agencies and safeguard the public's rights to know, participate and supervise. ${ }^{52}$ It added that the State Council was drafting FOI Regulations, and that FOI law would be enacted based on the experiences learnt from implementation of the Regulations. ${ }^{53}$ This indicates that FOI Regulations would be adopted before the adoption of FOI law.

48 Hanhua Zhou, Academic Draft of FOI Regulations (in Chinese) ( $1^{\text {st }}$ ed, 2003) 18; Mingjie Zhang, Open Government: Research on FOI Laws (in Chinese) $\left(1^{\text {st }} \mathrm{ed}, 2003\right) 218$.

49 The effectiveness of local FOI Rules was undermined by other conflicting regulations and laws as they have higher levels of legal authority than FOI Rules. See Shihong Huang, 'Pay Attention to the Sessions of the Chinese People's Political Consultative Conference and the National People's Congress' (in Chinese) Fujian Daily (Fuzhou) 12 March 2007, 2; Zuobin Liao and Xiaozhen Cheng, 'Focus on the Sessions of the Chinese People's Political Consultative Conference and the National People's Congress' (in Chinese) Information Times (Beijing) 4 March 2003, A3.

so The Standing Committee of the $10^{\text {th }}$ National People's Congress published its legislative plan in 2003. The plan has been classified into two categories. 59 bills and amendments fell into the priority category and amendments which should be reviewed in the $10^{\text {th }}$ National People's Congress, while 17 bills and amendments that fell into the secondary priority, were required to carry out research and draft. Whether these 17 bills and amendments can be reviewed or not depended on the real situation.

51 The Legislative Plan of the $10^{\text {th }}$ Standing Committee of the National People's Congress (in Chinese) (2003) The National People's Congress <http://www.npc.gov.cn/npc/xinwen/rdyw/wj/2 004-02/23/content_328577.htm> at 31 May 2008.

52 The Report on the Review Results of the Proposals from the Deputies of the Second Plenary Session of the $10^{\text {th }}$ National People's Congress by the Internal and Judicial Affairs Committee of the National People's Congress 27 October 2004

Ibid. 
While the adoption of FOI Regulations before law contrasts with common law legal traditions, the Chinese government elected to do so because the process is more rapid than the adoption of FOI law. ${ }^{54}$ Furthermore, it was recognised that FOI Regulations would form an integral part of the Chinese legal system, and did not lack status because courts could take them into account as criteria to handle administrative lawsuits. ${ }^{55}$ Thus, in China, FOI Regulations, which have basic elements similar to FOI law, have a strong impact on government activities, although they cannot override conflicting laws. In addition, introducing regulations prior to law met previous Chinese law-making practices. ${ }^{56}$ Many administrative laws were not adopted until several years after the implementation of their related regulations, ${ }^{57}$ such as the Administrative Reconsideration Law 1999 and the Civil Servant Law 2005. Implementation of FOI Regulations assists China to gain experiences for better designing and implementing future FOI law. ${ }^{58}$

\subsubsection{Informatisation agencies: invigorating legislation of FOI}

The Leading Group of National Informatisation (LGNI) and the State Council Informatisation Office (SCIO) promoted FOI from the perspective of informatisation development, and initiated the legislation of FOI in China. ${ }^{59}$ Supported by the policy document, titled 'Guidance on Building E-Government' (see 6.1.3), ${ }^{60}$ the SCIO commissioned the Law Institute of the Chinese Academy of Social Science to draft FOI Regulations in May 2002. ${ }^{61}$ The legislative process lasted for three months and an early draft was presented to the SCIO in August. ${ }^{62}$ On 29 August, the SCIO held a forum with experts on this draft. On 14 September, the SCIO commissioned the State Information Centre to hold a seminar on the draft, and solicited comments and

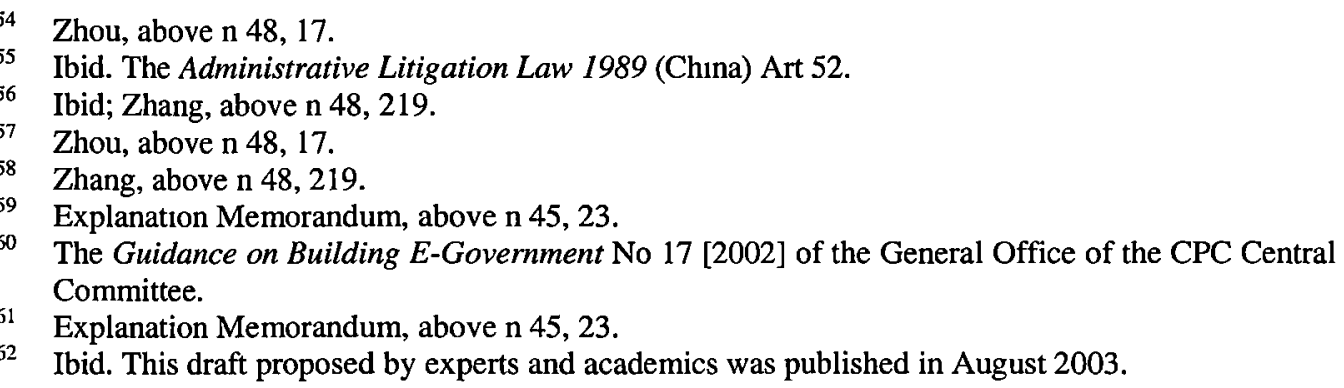


suggestions from experts and government officials. The draft was amended during October and November after negotiation with other ministries, including the Ministries of Science and Technology, and Information Industry. Then on 27 December 2002, the draft of FOI Regulations was finalised by academics and submitted to the State Council Legislative Affairs Office, the agency that assists the Premier to handle legislative affairs. ${ }^{63}$ However, the State Council Legislative Affairs Office had little passion for FOI Regulations before $2006,{ }^{64}$ which was understandable during this period, when local FOI rule-making activities were largely absent and the rationale of economic growth predominated over others in the FOI reform initiative.

\subsubsection{Anti-corruption agencies: making great efforts}

The national anti-corruption or supervisory agencies, the Central Commission for Discipline Inspection (CCDI) and the Leading Group on National Openness in Government Affairs (LGNOGA), contributed to promote FOI in China as a tool for preventing corruption from $2004 .{ }^{65}$ Yong He, the Deputy Secretary of CCDI, first mentioned FOI in his speech at the second meeting of the LGNOGA in April $2004{ }^{66}$ In March 2005, at the fourth meeting of the LGNOGA, he called for the formulation of FOI Regulations. ${ }^{67} \mathrm{He}$ recalled that the General Office of the LGNOGA had drafted the Notice on Further Promoting Openness in Government Affairs ${ }^{68}$ in July 2004 , and suggested that the formulation of FOI Regulations be accelerated. ${ }^{69}$ This

63 Explanation Memorandum, above n 45, 24; Hanhua Zhou, 'The Legislative History of FOI Regulations in China' (in Chinese) (2008) 7 E-Government 15, 17.

64 Zhou, above $\mathrm{n} 38$.

$65 \mathrm{He}$, above $\mathrm{n} 47$.

66 Ibid.

67 Yong He, 'The Speech of Yong He at the Fourth Meeting of the Leading Group on National Openness in Government Affairs' (Speech delivered at Beijing, 25 March 2005).

68 The Notice on Promoting Openness in Government Affairs around All Government Agencies at the Township Level, above $\mathrm{n} 2$.

69 Yong He, 'The Leading Group on National Openness in Government Affairs Answered the Questions from Journalists about the Notice on Further Promoting Openness in Government Affairs' (Press Release, 27 April 2005). 
Notice, issued in March $2005,{ }^{70}$ accepted the need to accelerate the formulation of FOI Regulations. The following two meetings of the LGNOGA after 2005 reiterated this need. ${ }^{71}$ The LGNOGA arranged a special discussion on FOI Regulations at its sixth meeting. ${ }^{72}$ The involvement of the anti-corruption agencies in the legislative process for FOI was another factor that helped improve the receptivity of the central government to FOI.

\subsubsection{The central government: commitment to adopting FOI Regulations}

The State Council and the CPC Central Committee are also major contributors to the promotion of FOI in China since 2004. In March 2004, Premier Wen, in his Report on the Work of the Government at the Second Session of the $10^{\text {th }}$ NPC, committed to establishing a disclosure system to make it easier for citizens to exercise their rights to know and supervise. ${ }^{73}$ Immediately after the conclusion of this Session, on 22 March 2004, the State Council issued the Implementation Outline for Pushing Forward Administration by Law in an All-Round Way. ${ }^{74}$ The Outline regarded FOI legislation as part of the framework of law-based administration, and required government agencies to adopt the legislation. ${ }^{75}$ In 2005 , the central government circulated the Notice on Further Promoting Openness in Government Affairs, reiterating the acceleration of the formulation of FOI Regulations. ${ }^{76}$

70 The Notice on Promoting Openness in Government Affairs around All Government Agencies at the Township Level, above $\mathrm{n} 2$.

71 Yong He, 'The Speech of Yong He at the Sixth Meeting of the Leading Group on National Openness in Government Affairs' (Speech delivered at Beijing, 31 March 2006); Yong He, 'The Speech of Yong He at the Seventh Meeting of the Leading Group on National Openness in Government Affairs' (Speech delivered at Beijing, 21 March 2007).

72 Xueshan Yang, 'Subsidiary Report on Learning FOI Regulations' (Speech delivered at Conference on Learning FOI Regulations, Beijing, 19 May 2007).

73 Jiabao Wen, 'Report on the Work of the Government to the National People's Congress' (Speech delivered at the Second Session of the $10^{\text {th }}$ National People's Congress, Beijing, 16 March 2004).

74 The Implementation Outline for Pushing Forward Administration by Law in an All-Round Way No 10 [2004] of the General Office of the State Council.

75 Ibid.

76 The Notice on Promoting Openness in Government Affairs around All Government Agencies at the Township Level, above $\mathrm{n} 2$. 
In response to these calls, the State Council listed the FOI Regulations as the second priority category of its legislative plan in 2004 and $2005 .{ }^{77}$ Since 2004, the State Council Legislative Affairs Office joined with the SCIO to revise the draft through extensive consultation with 46 state agencies and 34 local governments and panel discussion with experts. ${ }^{78}$ In addition, the State Council Legislative Affairs Office held the Sixth China-Germany Law Forum in 2005 to discuss legal issues concerning FOI. ${ }^{79}$ However, FOI legislation was not an openly developed policy in China. The legislative process lacked public participation and the draft of FOI legislation was not publicised. ${ }^{80}$ In 2006 , the State Council listed the FOI Regulations as the first priority category of its legislative plan for the first time, signalling that the Regulations would be adopted within that year. ${ }^{81}$ However, the State Council postponed the approval of the legislative plan, the adoption of the FOI Regulations in principle, until 17 January 2007. ${ }^{82}$ Further amendments were required. The State Council published the final version of the Regulations on 24 April 2007.

\subsection{Conclusion}

This chapter shows that FOI reform in China formed part of a much longer process of increased transparency. The government first gained experiences from the work of OVA. OGA followed OVA, but was trialled by township government agencies, and expanded to government agencies at both county and province levels several years later. Furthermore, many city and provincial governments adopted and implemented FOI Rules in their own localities after 2002. These sub-national OGA and FOI practices enhanced information flow in the Chinese information environment, thus

\footnotetext{
77 Hanhua Zhou, 'Regulation on Government Information Publication in China: Practice, Problems and Prospect' (Speech delivered at Conference on China Policy Dialogue 2005, Columbia, 1 June 2005).

78 The Journalist in the China Legislative Information Network System, Interview with a Leader in the State Council Legislative Affairs Office (Beijing, 25 April 2007).

79 Ibid.

80 Hanhua Zhou, 'Significance and Features of Introducing FOI Legislation in China' (in Chinese) (2007) 6 China Today Forum 29, 30.

81 The Notice on Suggestions for Enforcing 2006's Legislation Work and 2006's Legislative Plan No 2 [2006] of the General Office of the State Council.

82 New Regulation Approved to Boost Government Transparency (2007) The Central Government <http://english.gov.cn/2007-01/17/content_499497.htm> at 12 March 2007.
} 
increasing China's capacity to accommodate the first national FOI legislation - the FOI Regulations. The Regulations will prepare a firm foundation for the introduction of the national FOI law in the future.

The gradual legislative process for FOI demonstrates that FOI developments in China followed a push to pull path (see 2.4.2), and this indicates that China will adopt a push model of FOI legislation which emphasises proactive disclosure. The next chapter explores this push model of FOI legislation in China. 


\section{8: CHINA'S LIMITED PUSH MODEL OF FOI LEGISLATION}

\subsection{Introduction}

This chapter examines China's FOI Regulations and argues that China has adopted a push model of FOI legislation that emphasises proactive disclosure of government information. This differs from a pull model that stresses citizen-initiated access or reactive disclosure (see 1.2.7). The push model of FOI legislation, which has reduced the importance of access requests in China, grew out of two decades of limited proactive disclosure practices around the country (see Chapter 4) and an improved information environment resulting from the formation of multiple paths for information flow (see Chapter 3). However, the degree of push or proactive disclosure under China's current FOI Regulations is undermined by several factors, including a limited access mechanism, broad and vague exemptions and omission of the maximum disclosure principle.

This chapter has five sections. Section one compares a pull model with a push model of FOI legislation. Section two explores a unique proactive disclosure system. Section three examines a limited access mechanism that constrains the proactive disclosure degree under the FOI Regulations. Section four explores broad and vague exemptions that further limit the push degree under the Regulations. The final section examines the omission of the maximum disclosure principle, which further undermines the proactive disclosure degree under the FOI Regulations. 


\subsection{Models of FOI legislation: pull versus push}

There are two factors - an improved information environment and new public management reform ${ }^{1}$ - that have generated new possibilities and capabilities for the global shift from a pull model of FOI legislation to a push model. ${ }^{2}$ China introduced a push model of FOI legislation, albeit as a response to two decades of limited proactive disclosure practices around the country and an improved information environment, which necessitated a subsidiary or reduced role for an access mechanism.

\subsubsection{An emerging global trend: from a pull to a push model}

Like recent FOI reform in Australian states, ${ }^{3}$ a push model of FOI legislation that emphasises proactive disclosure and takes access requests as a last resort ${ }^{4}$ has emerged around the globe in recent years. An improved information environment,

1 The idea and practice of New Public Management emerged in the 1980s in the UK to reform public administration and public service according to a citizen-as-customer view. Many counties followed suit in the 1990s due to the promotion by international institutions, such as the World Bank. See Christopher Hood, 'A Public Management for All Seasons' (1991) 69 Public Administration 3-19; Michael Barzelay, 'Origins of the New Public Management: An International View from Public Administration/Political Science' in Kathleen McLaughlin and Stephen Osborne (eds), New Public Management: Current Trends and Future Prospects (2001) $15,15$.

2 Dag Wiese Schartum, 'Information Access Legislation for the Future? Possibilities according to a Norwegian Experience' in Georg Aichholzer and Herbert Burkert (eds), Public Sector Information in the Digital Age: Between Markets, Public Management and Citizens' Rights (2004) 69, 76; Massimo Craglia and Michael Blakemore, 'Access Models for Public Sector Information: The Spatial Data Context' in Georg Aichholzer and Herbert Burkert (eds), Public Sector Information in the Digital Age · Between Markets, Public Management and Citizens' Rights (2004) $187,187$.

3 The FOI Independent Review Panel, The Right to Information. Reviewing Queensland's Freedom of Information Act (2008); Tasmanian Department of Justice, Strengthening Trust in Government ... Everyone's Right to Know Directions Paper (2009); The Department of Premier and Cabinet in New South Wales states that ' $[\mathrm{t}]$ he new legislation shifts the focus toward greater proactive disclosure'. The Department of Premier and Cabinet in New South Wales, Open Government Information: FOI Reform in New South Wales Companion Guide to the Bills (2009). See http://www.dpc.nsw.gov.au/prem/foi reform - open government information. The New South Wales Parliament passed new FOI legislation on 26 June 2009. One objective of the new FOI legislation is 'authorising and encouraging the proactive public release of government information by agencies'. Government Information (Public Access) Act 2009 (NSW) Art 3.

4 Herbert Kubicek, 'Third-Generation Freedom of Information in the Context of E-Government: The Case of Bremen, Germany' in Georg Aichholzer and Herbert Burkert (eds), Public Sector Information in the Digital Age: Between Markets, Public Management and Citizens' Rights (2004) 275, 280; Moira Paterson, Freedom of Information and Privacy in Australia $\left(1^{\text {st }} \mathrm{ed}, 2005\right) 498$. 
together with new public administration reform programs, has prompted the push model. A pull model, albeit neatly accommodated to the pre-Internet era of public administration, therefore is now outdated. The need for FOI to respond and adapt to an information age was a major theme of Roberts's work. ${ }^{5}$

\section{A pull model: emphasising reactive disclosure}

A pull model of FOI legislation was adopted by liberal democracies to solve the accountability deficit arising from a perceived growth in government power (see 1.1.1). This indicates that most FOI legislation between the 1960s and the 1980s had a strong 'antagonistic' ${ }^{6}$ and individualised nature. ${ }^{7} \mathrm{~A}$ pull model was the result of a compromise between key demand side players, including the media and the parliament, and the executive. ${ }^{8}$ Globalisation, promoted by international institutions such as the World Bank, has led to many recent FOI adopters favouring a pull model.

\section{A push model: emphasising proactive disclosure}

New public management reform indicates that public administration has begun to shift from a 'government-oriented' to a citizen or 'customer-oriented' approach. ' This has opened up the possibility for a push model of FOI legislation that emphasises proactive disclosure or 'enabling' access. ${ }^{10}$ Thus, the environment that surrounds FOI legislation has changed into a less 'antagonistic' one, ${ }^{11}$ although, as noted by Roberts, government restructuring has weakened the effectiveness of FOI legislation by

$5 \quad$ Alasdair Roberts, Blacked out: Government Secrecy in the Information Age (1 ${ }^{\text {st }}$ ed, 2006) 199227; Alasdair Roberts, 'Dashed Expectations: Governmental Adaptation to Transparency Rules' in Christopher Hood and David Heald (eds), Transparency: The Key to Better Governance? (2006) 107, 114-5; Alasdair Roberts, 'Future Challenges for the RTI Movement' (Speech delivered at the $5^{\text {th }}$ International Conference of Information Commissioners, Wellington, 26-29 November 2007).

Schartum, above $\mathrm{n} 2$.

7 Greg Terrill, 'Individualism and Freedom of Information Legislation' (2000) 87 Freedom of Information Review 30, 30.

8 Schartum, above $\mathrm{n} 2$.

9 Schedler and Proeller argue that one key element of new public management is customer orientation or quality management, which can be exemplified by one-stop shops, service level agreements and e-government. See Kuno Schedler and Isabella Proeller, 'The New Public Management: A Perspective from Mainland Europe' in Kathleen McLaughlin and Stephen Osborne (eds), New Public Management: Current Trends and Future Prospects (2001) 163, 165.

10 Craglia and Blakemore, above $\mathrm{n} 2$.

11 Schartum, above n 2, 76-7. 
limiting its coverage, including the bodies and subject matter. ${ }^{12}$

More importantly, the significance of citizen-initiated access has been reduced in the information age, ${ }^{13}$ requiring a push model of FOI legislation to be introduced to adapt to the changed information environment. Information flow, with the assistance of information technology, has become easier and more frequent. FOI academics, such as Snell, call for a shift from 'version 1.0' FOI focusing on reactive disclosure to 'version $2.0^{\prime}$ emphasising proactive disclosure. ${ }^{14}$ Government agencies have also become more receptive to information sharing in order to adapt to an improved information environment. The US revised its FOI legislation in 1996 to accommodate to the information age, changing its strong pull version to include more proactive disclosure requirements. ${ }^{15}$ The UK FOI law provides for a publication scheme, which requires government agencies to provide information to the public routinely and proactively. ${ }^{16}$ In Mexico, government agencies are required to publish an extensive amount of information on their websites. ${ }^{17}$ More importantly, Australia is taking the lead in promoting a push model to become policy, especially at the sub-national level. Queensland, Tasmania and New South Wales are presently developing this model. ${ }^{18}$

12 Alasdair Roberts, 'Structural Pluralism and the Right to Information' (2001) 51 University of Toronto Law Journal 243, 244.

13 Schartum, above n 2, 77; Robert Gellman, 'The Foundation of United States Government Information Dissemination Policy' in Georg Aichholzer and Herbert Burket (eds), Public Sector Information in the Digital Age: Between Markets, Public Management and Citizens' Rights (2004) $123,126$.

14 Rick Snell, 'Opening up the Mindset Is Key to Change' (2008) The Canberra Times 4 November 2008, 10-1 1; Paterson also calls for the improvement of FOI legislation by establishing 'an obligation for agencies to anticipate requests and to use information technology to make broad categories of information immediately available in a readily accessible form'. See Paterson, above n 4 .

15 Gellman, above n 13; Michael Tankersley, 'How the Electronic Freedom of Information Act Amendments of 1996 Update Public Access for the Information Age' (1998) 50 Administrative Law Review 421, 422.

16 Freedom of Information Act 2000 (UK) Arts 19, 20.

17 Federal Transparency and Access to Public Government Information Law 2002 (Mexico) Arts 7, 9.

18 See above $\mathrm{n} 3$ and the accompanying text. 


\subsubsection{FOI legislation in China: a limited push model}

China's adoption of a push model of FOI legislation has been chiefly for domestic reasons. Three factors merit prominence for this adoption. The first is the previous two decades of Openness in Government Affairs (OGA), closely linked to a long term democratisation process (see 4.3 and 7.1). For a significant period of this democratisation process, the focus has been on the capacity and the willingness of the government to share information with citizens. Proactive disclosure requirements under the FOI Regulations have provided a summary of the previous work of OGA that has focused on proactive disclosure. ${ }^{19}$ FOI legislation has helped institutionalise the work of OGA to solve many problems, including the government's unlimited discretion to disclose information and its non legally-binding disclosure duty ${ }^{20}$ The institutionalisation of OGA can solve these problems and perpetuate the duration of OGA experiments. ${ }^{21}$

Second, the push model of FOI legislation in China was the outcome of an improved information environment due to the formation of multiple paths for information flow. China increased its information flow by following a push to pull path (see 2.4.2). Improving information flow within the demand side caused the Chinese government to become more proactive in releasing government information. The emphasis on proactive disclosure may be more effective than the focus on reactive disclosure in prompting government officials to abandon their longstanding secretive and reactive information management approach that has been proven outdated in the improved Chinese information environment (see 3.2.3). Furthermore, the government's capacity to proactively disclose information has increased now that government websites have been launched and spokesperson systems have been established (see 3.2.3).

19 Xueshan Yang, 'Subsidiary Report on Learning FOI Regulations' (Speech delivered at Conference on Learning FOI Regulations, Beijing, 19 May 2007).

20 Hanhua Zhou, 'FOI Regulations Will Bring about Six Changes' (in Chinese) People's Daily (Beijing) 14 February 2007, 13.

21 The Notice on Further Promoting Openness in Government Affairs No 12 [2005] of the General Office of the CPC Central Committee. 
Another factor also supported the adoption of the push model of FOI legislation in China. The emphasis on proactive disclosure may have reduced the workload of government agencies arising from the process of access requests due to China's huge population, vast territory and high volume of government information. ${ }^{22}$ These unique features have required reduced importance to be placed on access requests in order to allow government agencies to exercise their core functions. This explains why several Chinese developing areas, like Hunan, are keen to adopt the push approach. The Hunan government considers that this approach can help it focus on other more urgent tasks in its locality. ${ }^{23}$

Whilst China's greater focus on proactive disclosure appears different from a universally accepted pull setting of FOI, the push model reflects a new approach to FOI in the information age and grew out of China's local conditions. However, China's push model of FOI legislation has been undermined by some of its key features (see 8.3), indicating that it is not an ideal push model which should have no such undermining features.

\subsection{A unique proactive disclosure system: evidence for a push model}

China's FOI Regulations include much broader requirements for proactive disclosure than FOI laws elsewhere. It sets forth minimum standards and general criteria for government agencies to determine the circumstances in which information is needed to be proactively disclosed. It also provides for other legal measures that can ensure compliance with proactive disclosure requirements. These legal measures are various means of proactive disclosure, varied locations and facilities for access, information inventory and guide requirements, time limits for publication, a reporting system and sanctions for non-compliance.

Yang, above n 19.

The Hunan Government, Freedom of Information Regulations 2007 Annual Report 2008. 


\subsubsection{A non-exhaustive list: minimum standards and general criteria}

While China's FOI Regulations were passed by the State Council in early 2007, they were not published until three months later. During these three months, there was vigorous debate about whether the Regulations should have a non-exhaustive list of the requirements for proactive disclosure. ${ }^{24}$ The FOI Regulations eventually contained a non-exhaustive list, which sets forth general criteria for government agencies to produce their own information that is needed to be proactively disclosed, and provides for a minimum standard to oblige different government agencies to emphasise active release of varied government information. The legal design combining minimum standards with general criteria can facilitate compliance with the FOI Regulations in a practical way.

\section{Minimum standards: for government agencies to stress}

China's FOI Regulations provide a minimum set of conditions for government agencies to determine information to be proactively disclosed. Three clauses establish minimum standards in the field of making government information publicly available by listing key information that is needed to be proactively disclosed. Article 10 requires government agencies at or above the county level to emphasise proactive disclosure of government information, such as information on legal documents, budgets and expenses, public health and food and drug safety. ${ }^{25}$ Article 11 obliges government agencies at the county level to stress disclosing additional information, such as information on land requisition and assistance to low income families. ${ }^{26}$ Article 12 emphasises information to be disseminated by government agencies at the township level, such as information on land use plans and implementation of family

24 Yijun Wang, 'The Breakthrough of Legislating on FOI after a Decade' (in Chinese) China Youth Daily (Beijing) 25 April 2007, 3.

25 Freedom of Information Regulations 2007 (China) Art 10. See Appendix 3 for the detailed requirements in this clause.

26 Freedom of Information Regulations 2007 (China) Art 11. See Appendix 3 for the detailed requirements in this clause. 
planning policies. $^{27}$

\section{Four general criteria: normal guidelines for decisions by government agencies}

A push model of FOI legislation calls for minimum standards, but general criteria must be established to aid government agencies to produce their own categories of information to be proactively disclosed. This is so in China. The FOI Regulations contain a general clause requiring government agencies to proactively disclose information satisfying any one of the following four general criteria: ${ }^{28}$

1. Information that involves the vital interests of citizens, legal persons or other organisations;

2. Information that needs to be extensively known or participated in by the general public;

3. Information that shows the structure, function and working procedures and the like concerning a government agency; or

4. Other information that must be proactively disclosed under laws, regulations and relevant rules.

This general clause sets broad standards for government agencies to justify government information subject to proactive disclosure. While the third criterion is also commonly found in a pull model of FOI legislation and the fourth criterion is only a residual criterion, the first two criteria are innovative and can encompass considerable government information. They also provide a useful analytical framework for examination of compliance with FOI legislation (see 9.2).

\subsubsection{Legal measures safeguarding proactive disclosure}

The Chinese government has devised at least six legal measures to ensure compliance with proactive disclosure requirements. The first includes various means of proactive disclosure, such as government websites, press conferences and government

27 Freedom of Information Regulations 2007 (China) Art 12. See Appendix 3 for the detailed requirements in this clause.

$28 \quad$ Freedom of Information Regulations 2007 (China) Art 9. 
bulletins. ${ }^{29}$ Press conferences are understood by the Chinese government as a useful means to disseminate government information (see 3.2.3). Further, government websites are required to be the priority platform for disseminating government information, ${ }^{30}$ thus reducing the use and importance of access requests. The central government requires government agencies to launch FOI sections, similar to electronic reading rooms, on their official websites. ${ }^{31}$ FOI sections of the websites have become an important platform for publishing information by government agencies. They also provide other functions that can facilitate access to information, such as online searching and information requesting.

The second legal measure to ensure compliance with proactive disclosure requirements is the provision of a variety of locations and facilities for accessing proactively disclosed information. ${ }^{32}$ More importantly, government agencies must provide all proactively disclosed information to national archives and public libraries in a timely manner. ${ }^{33}$ This requirement goes beyond legislating state archives' previous experiments with receipt and release of current document (Xing Xing Wenjian) since $2000 .{ }^{34}$ It covers all sorts of proactively disclosed information. Furthermore, the FOI Regulations have placed equal importance on libraries and archives to provide government information services to the public. The requirement for providing government information to libraries has resolved the dilemma faced by libraries, which cannot subscribe to official documents without an ISBN or ISSN. ${ }^{35}$

29 Article 15 requires government agencies to proactively disclose government information through government bulletins, government websites, press conferences, newspapers and periodicals, radio, television or any other means easy for the general public to access.

30 The Notice on Preparing for the Implementation of FOI Regulations No 54 [2007] the General Office of the State Council.

31 Ibid.

32 Freedom of Information Regulations 2007 (China) Art 16.

33 Freedom of Information Regulations 2007 (China) Art 16.

34 In 2000, the Shenzhen archives became the pioneer in receiving current documents from all local government agencies and providing them to the public on request. This new government information services were expanded to other localities rapidly. In 2003, the number of the centres rose to 220 around the country. See Si Guan, 'Rapid Development, Broad Coverage and Various Methods: Discussion of the Use of Current Documents' (in Chinese) (2004) 2 China Archives 7, 7

35 Interview with Librarians (Interview in Person, 22 June; 8 July 2008). In the past, only very limited categories of government information, such as official bulletins, were subscribed to by 
The third legal measure is the compilation and publication by government agencies of their information inventories and guides. ${ }^{36}$ The inventory includes index, name, abstract, date of generation and other particulars of government information. ${ }^{37}$ This not only aids requesters to formulate their requests, but assists government agencies to manage information effectively. ${ }^{38}$ Government agencies must also compile and publish information guides and update them on a timely basis. ${ }^{39}$ Guides include methods of cataloguing, categorising and obtaining government information, as well as details of the relevant FOI offices' name, business address, office hours, telephone number, fax number and e-mail. ${ }^{40}$ The requirement of information inventories and guides shows government willingness to proactively disclose information. ${ }^{41}$ It provides the public with basic information about the documents held by government and the methods used to arrange them. ${ }^{42}$

The fourth legal measure is the time limit for disseminating government information. The Regulations require proactively disclosed information to be released within 20 days from the date the information is generated or changed. ${ }^{43}$ The time limit is rarely found in other countries' FOI legislation, and avoids an unreasonable delay of the information required to be proactively disclosed.

The fifth legal measure is a reporting or complaint mechanism. Citizens are entitled to report government failure to adhere to proactive disclosure requirements to the

public libraries. Libraries even cannot subscribe to these documents after 2003 as the central government prevented government agencies from undertaking pressured subscription for official publications. This means that any official documents without an ISBN or ISSN cannot be available for subscription. See The Notice on Further Governing the Abusive Distribution of Party and Official Publications by Taking Advantage of Their Position and Power to Alleviate Primary Levels and Farmers' Burden No 19 [2003] of the General Office of the CPC Central Committee.

Freedom of Information Regulations 2007 (China) Art 19.

Freedom of Information Regulations 2007 (China) Art 19.

Tankersley, above n 15, 423.

Freedom of Information Regulations 2007 (China) Art 19.

Freedom of Information Regulations 2007 (China) Art 19.

41 Snell and Sebina argue that 'if governments are unable to maintain and operate good records management programs, it is unlikely that they will be transparent and accountable'. See Rick Snell and Peter Sebina, 'Information Flows: The Real Art of Information Management and Freedom of Information' (2007) 35 Archives and Manuscripts 55, 73.

42 Tankersley, above n 15, 424.

$43 \quad$ Freedom of Information Regulations 2007 (China) Art 18. 
supervisory agencies responsible for investigating reports or complaints. ${ }^{44}$ This mechanism gives the public an opportunity to assist the central government to discover and redress non-compliance with proactive disclosure in practice.

The final legal measure concerns administrative sanctions. Government agencies and officials are subject to administrative sanctions for failing to perform duties to disclose government information or updating categories concerning proactive disclosure, information inventories and guides on a timely basis. ${ }^{45}$ Sanctions play an important role in ensuring compliance with proactive disclosure in practice.

\subsection{A limited access mechanism}

A limited information access mechanism is a factor that undermines the degree of proactive disclosure under China's FOI legislation. The access mechanism is constrained by an obscure authorisation of the access right, and a potential need test. Whilst senior Chinese officials state that the FOI Regulations have been adopted to safeguard the access right, ${ }^{46}$ the practical effect of this statement is limited.

\subsubsection{An implied access right}

While the FOI Regulations allow access to government information, they do not explicitly confer an access right. Before the passage of the Regulations, there were disputes about their ability to do so. ${ }^{47}$ The access right was also not specially mentioned under the Constitution $1982 .{ }^{48}$ As a result, there was a general consensus that the FOI Regulations were an inappropriate legal document to confer this political right, signalling that it can only be protected indirectly by the Regulations. ${ }^{49}$ Indirect protection can constrain Chinese citizens' capacity to access general government

Freedom of Information Regulations 2007 (China) Art 33.

45 Freedom of Information Regulations 2007 (China) Art 35.

46 Qiong Zhang, 'The Legislative Affairs of the State Council Introduces FOI Regulations' (Press Release, 24 April 2007).

47 Yunfan Zhou, 'Analysis of FOI Law-Making Activities in China' (in Chinese) (2005) 6 Journal of Jinan University 54, 57.

48 Hanhua Zhou, Academic Draft of FOI Regulations (in Chinese) (1 $\left.{ }^{\text {st }} \mathrm{ed}, 2003\right) 16$.

49 Explanation Memorandum, The Draft of FOI Regulations 2002 (China) 25. 
information or compel government agencies to rectify non-compliance with proactive disclosure, as there has been much debate on whether or not the access right falls outside the scope of administrative lawsuits (see 10.2.2).

\subsubsection{A potential need test}

International best practice dictates anyone should be able to exercise the access right, whether or not they have any ground or legal interest. ${ }^{50}$ China's FOI Regulations do not meet this aspect of best practice. The Regulations enable citizens, legal persons or other organisations to request information held by government agencies in accordance with their needs in business, daily life, research or other special needs. ${ }^{51}$ A purpose for information sought is required, although the definition of purpose is so broad that requesters can easily meet this requirement. ${ }^{52}$

In terms of the concern that government agencies are likely to refuse access requests with the excuse that the information requested does not meet requesters' special needs, ${ }^{53}$ the State Council clarifies that government agencies may refuse access requests if information sought is unrelated to the requesters' special needs. ${ }^{54}$ Furthermore, local governments, which adopted FOI legislation prior to the central government, have changed their previous practices that did not require a purpose for access requests (see 10.1.3). The degree of proactive disclosure is therefore restricted by this retreat.

50 The Open Society Justice Initiative, Transparency \& Silence: A Survey of Access to Information Laws and Practices in 14 Countries (2006) Open Society Institute \& Soros Foundations Network $<$ http://www.soros.org/resources/articles_publications/publications/transparency_20060928/transp arency_20060928.pdf $>$ at 12 November 2006; Venkat Iyer, Freedom of Information: Principles for Legislation (2000) UNPAN <http://unpan1.un.org/intradoc/groups/public/documents/APCITY /UNPAN002177.pdf> at 13 July 2007.

$51 \quad$ Freedom of Information Regulations 2007 (China) Art 13.

52 Interview with a Chinese Government Official (Interview in Person, 16 June 2008).

53 Jamie Horsley, China Adopts First Nationwide Open Government Information Regulations (2007) Freedom of Information Organisation <http://www.freedominfo.org/features/20070509.htm> at 12 May 2007.

54 Several Suggestions on the Implementation of the FOI Regulations No 36 [2008] of the General Office of the State Council. 


\subsection{Broad and vague exemptions}

The degree of proactive disclosure under the FOI Regulations has arguably been weakened by broad and vague exemptions. Whilst exemptions are a standard element of FOI legislation, exemptions under China's FOI Regulations remain less liberal than is ideal, in at least the following six aspects.

First, the scope of exemptions under the FOI Regulation is inconsistent with best practice,${ }^{55}$ though the Regulations ostensibly set out very limited exemptions - the main exemption clause only prevents government agencies from disclosing information concerning state secrets, trade secrets and privacy. ${ }^{56}$ Other exemptions are stated in general in Article 8, which exempts information that may prejudice state security, public security, economic security or social stability. Much government information will remain hidden under this general exemption ${ }^{57}$ Moreover, whilst the FOI Regulations do not provide administrative grounds for refusing access requests, the central government considers repeated requests as administrative grounds to exercise the discretion whether or not to respond. ${ }^{58}$

Second, exemptions and exclusions under FOI legislation should be clearly and narrowly defined ${ }^{59}$ to 'exclude material which does not harm legitimate interests' ${ }^{60}$ This is not the case in China. Exemptions and exclusions are not clearly and narrowly defined under the FOI Regulations, which prevent government agencies from disclosing any information that may be injurious to state security, public security,

Article 19, Right to Know: Principles on Freedom of Information Legislation (1999) <http://www.article19.org/pdfs/standards/righttoknow.pdf> at 1 July 2007.

56 Freedom of Information Regulations 2007 (China) Art 14.

57 Benjamin Kang Lim and Shipeng Guo, China Vows Government Transparency, within Limits (2007) Reuters <http://www.reuters.com/article/idUSPEK7649220070424> at 22 September 2008; Fowler Geoffrey and Juying Qin, 'China Moves to Boost Transparency, But Much Is Kept Hidden' Wall Street Journal (New York), 25 April 2007, A6.

58 Several Suggestions on the Implementation of FOI Regulations, above n 54.

59 Iyer, above n 50; Article 19, above n 55.

60 Article 19, above n 55. 
economic security or social stability. ${ }^{61}$ The definition of these securities is left to government agencies, and so can easily be used to refuse access requests.

Meanwhile, state secrets, trade secrets and privacy are not well defined under the FOI Regulations and other laws. ${ }^{62}$ Zhou argues that a broad scope for the state secret exemption will impede implementation of the FOI Regulations. ${ }^{63}$ This is a reasonable view. The Law on the Protection of State Secrets 1988 has not yet revised, and the scope of state secrets remains unchanged. The longstanding culture of secrecy, although beginning to change (see 3.2), has impeded efforts to narrow the scope of state secrets. The definition of privacy is not 'yet addressed comprehensively in Chinese law', ${ }^{64}$ which in turn may negatively affect the operation of the FOI Regulations. Although trade secrets are defined in Article 10 of the Anti-trust Law $1993,{ }^{65}$ it is uncertain whether or not this definition will be widened to include information in government procurements and other contracts to which the government is a party.

Third, class-based exemptions should be avoided. Again, this is not the case in China. It is argued that any FOI law should avoid sweeping 'class exemptions', ${ }^{66}$ which exclude 'entire classes of information from access' ${ }^{67}$ Under China's FOI Regulations, state secrets, trade secrets, and privacy are all class-based exemptions. ${ }^{68}$

Fourth, government agencies are prevented compulsorily from disclosing any exemption under the FOI Regulations. Discretionary rather than mandatory

\footnotetext{
Freedom of Information Regulations 2007 (China) Art 8.

Horsley, above $\mathbf{n} 53$.

Zhou, above $\mathrm{n} 48,113$.

Horsley, above n 53; Lei Zheng, 'Enacting and Implementing Open Government Information Regulations in China: Motivations and Barriers' (Paper presented at the First International Conference on Theory and Practice of Electronic Governance, Macao, 10-13 December 2007). Trade secrets refers to any technology information or business operation information which is unknown to the public, can bring about economic benefits to the obligee, has practical utility and about which the obligee has adopted secret-keeping measures. The Anti-trust Law 1993 (China) Art 10.

66 Iyer, above n 50.

67 Maurice Frankel, Freedom of Information: Some International Characteristics (2001) The Campaign of Freedom of Information <http://www.cfoi.org.uk/pdf/amsterdam.pdf> at 13 November 2006.

68 Freedom of Information Regulations 2007 (China) Art 14.
} 
exemptions should be provided under FOI legislation, ${ }^{69}$ as the former leaves the way open for government agencies to exercise their right in favour of disclosure, even though the information sought falls within an exemption provision. ${ }^{70}$

Fifth, although China's FOI Regulations include a harm test that features prominently in many FOI laws around the world and is advocated by FOI campaigners, ${ }^{71}$ they envisage only a low degree of harm for exemptions concerning state security, public security, economic security or social stability. They contain the verb harm without any adverb, such as significantly or substantially, to describe the degree of injury. No harm test applies to an exemption concerning state secrets, trade secrets or privacy under the Regulations, which means these exemptions are "class-based' ${ }^{72}$ Once the information sought falls into any of these categories, it is excluded from disclosure.

Sixth, China's FOI Regulations allow a special public interest test applied only to a few exemptions, rather than a general one that requires the consideration of public interest in each and every case. ${ }^{73}$ FOI laws generally require that any exemption must be balanced against disclosure in the public interest. ${ }^{74}$ This allows information to be released when 'public benefit in knowing the information outweighs any harm that may be caused from disclosure' ${ }^{75}$ In China, a public interest test is only applied specifically to exemptions of trade secrets and privacy. ${ }^{76}$

69 Thomas Hart, 'Freedom of Information/Access to Government Information Checklist: Minimum Requirements for a Freedom of Information Act (FOIA) and Its Implementation' (EU-China Information Society Project, 2005-2009).

70 Maeve McDonagh, Freedom of Information in Ireland ( $1^{\text {st }}$ ed, 1998) 84.

71 Article 19, above n 55.

72 McDonagh, above n 70.

73 Mclsaac classifies a public interest test into two categories: a general and special test. See Barbara Mclsaac, The Nature and Structure of Exempting Provisions and the Use of the Concept of a Public Interest Override (2001) Access to Information Review Task Force in Canada $<$ http://www.atirtf-geai.gc.ca/paper-nature1-e.html> at 15 April 2008.

74 A special public interest test is found in FOI legislation of Australia, Ireland, Canada and the United Kingdom. A general public interest test is found in FOI legislation of New Zealand, India and South Africa.

75 David Banisar, Effective Open Government: Improving Public Access to Government Information (2005) OECD<http://www.olis.oecd.org/olis/2005doc.nsf/0/cb40b8eb18975d01c1256fd300582d2 $\mathrm{d} / \$ \mathrm{FILE} / \mathrm{JT00181243.PDF}>$ at 11 August 2007.

76 Freedom of Information Regulations 2007 (China) Art 14. 
Government officials are likely to use these vague and broad exemption clauses to constrain the proactive disclosure degree under the FOI Regulations. These exemption clauses will shade many areas, and may become major impediments to future implementation of FOI legislation in China.

\subsection{Omission of the maximum disclosure principle}

The omission of the maximum disclosure principle has further diminished the proactive disclosure capacity of the Chinese FOI Regulations. It has been recognised that an ideal principle should be "maximum disclosure ${ }^{, 77}$ and that 'disclosure is the principle, while exemption is the exception' ${ }^{78}$ The FOI Regulations do not set out this principle. The central government revised local FOI Rules ${ }^{79}$ to return to a level of information disclosure that the government can accept at the present stage. While Premier Wen and other senior government officials state that the maximum disclosure principle is implied under the FOI Regulations, ${ }^{80}$ the practical effect of this statement remains uncertain.

The omission of this principle reflects the Chinese government's pragmatic strategy during the last three decades (see 1.2.6). It appears that 'secrecy still enjoys priority during the process of information disclosure' ${ }^{81}$ Thus, a special principle is found under Article 8 of the FOI Regulations, which prohibits government agencies disclosing government information that may prejudice state security, public security, economic security or social stability. Article 8 is also considered by law reformers as a basic principle for guiding government agencies to disclose information. ${ }^{82}$ This basic principle, which can encourage government officials to err on the side of secrecy, explains the lack of the maximum disclosure principle.

\footnotetext{
77 Article 19, above n 55.

78 The Open Society Justice Initiative, above n 50.

79 FOI Rules in Hebei, Hubei, Jiangsu and Liaoning Provinces provided for this principle.

80 Jiabao Wen, 'Seriously Adhere to the Spirits of the $17^{\text {th }}$ National Congress of the CPC to Promote Vigorously the Work of Incorruptibility Construction and Anti-Corruption' (in Chinese) (2008) 9 Qiushi 3, 6; Zhang, above n 46.

81 Fuzhi Chen, 'Several Issues in Relation to FOI Regulations (Pt 2)' (in Chinese) (2008) 1 China Public Administration 21, 22.

$82 \quad$ Yang, above $\mathrm{n} 19$.
} 


\subsection{Conclusion}

This chapter argues that China's push model of FOI legislation was the outcome of its local causes, and this model has reduced the importance of access requests. The push model of FOI legislation reflects the push to pull development of FOI in China (see 2.4.2). Furthermore, the proactive disclosure requirements under the FOI Regulations provide a clear obligation and minimum standard for government agencies to follow, thus reducing difficulty in government compliance. However, the degree of proactive disclosure under China's FOI legislation has been constrained by a limited access mechanism, broad and poorly defined exemptions and the omission of the maximum disclosure principle. It is necessary to relax these constraints in the future FOI law to increase the push degree.

The next two chapters analyse the prospects for the implementation of FOI legislation in China. 


\section{9: COMPLIANCE WITH PROACTIVE DISCLOSURE REQUIREMENTS IN PRACTICE}

\subsection{Introduction}

This chapter explores the strengths in the implementation of FOI legislation in China. It argues that the real strength of the way that FOI legislation is implemented in China is in compliance with proactive disclosure requirements. The chapter utilises a revised compliance analysis model that incorporates a push and pull focus to identify the forces that can ensure government compliance with proactive disclosure requirements under China's FOI Regulations. It finds that government willingness and capability to comply with proactive disclosure requirements can be ensured due to a strong central political commitment and various transparency advocacy groups on the supply side. The level of compliance can increase further because active players on the demand side are willing and able to cause government agencies to rectify their non-compliance with proactive disclosure in practice. To connect the strength of FOI legislation with compliance with proactive disclosure requirements may appear excessively optimistic or simply insignificant. However, the push nature of China's FOI Regulations suggests that compliance with proactive disclosure deserves more attention. This argument does not neglect the immense obstacles or challenges concerning compliance with FOI legislation in China, as demonstrated in Chapter 10.

This chapter has four sections. The first section explores the willingness and capability of the supply side/government to comply with FOI legislation. Section two examines the supply side's adherence to dissemination requirements set out in FOI legislation. Section three explores the role of the review system in helping the demand side/the public improve the capacity to rectify government non-compliance 
with the active distribution duty. The final section examines the role of the demand side, led by rights activists, legal professionals and interested citizens, in effectively holding the government to active release requirements. The level of compliance with proactive disclosure has thus increased due to the input from demand side players.

\subsection{The supply side: willingness and capability to implement FOI legislation}

A singular focus on the problems of reactive disclosure and its effective enforcement in China is misleading (see 1.3.3). The thesis calls for attention to three decades of significant changes and trends that have influenced the willingness and capability of the Chinese government to implement and comply with FOI legislation. It argues that a central political commitment and a number of transparency advocacy groups on the supply side have caused other government agencies to become more transparent (see 9.1.1). Furthermore, the capability of the government to implement FOI legislation has increased due to changed technological, political, legal, economic and civil service conditions (see 9.1.2). The foregoing has yielded a positive result in terms of adherence to proactive disclosure requirements laid down in FOI legislation.

\subsubsection{The supply side: willingness to implement FOI legislation}

The revised compliance analysis model incorporates a focus on the supply side. This can help identify various transparency advocacy groups on the supply side. These groups have responded to the opportunities arising from FOI legislation in China in order to perform their administrative functions better. Along with a strong central political commitment, these groups have devoted resources to ensuring the enforcement of FOI legislation. 


\section{A central political commitment}

The central political commitment, a major obstacle in enforcing FOI legislation, has been overcome in China (see 1.2.5), ${ }^{1}$ although this does not necessarily mean that the central government will commit to being fully observed or subject to direct accountability. The exemptions laid down in the FOI Regulations already indicate this point well (see 8.4). Furthermore, the central political commitment, albeit an important factor, does not necessarily result in lower tiers of government embracing it because various factors, such as limited resources, poor-trained FOI staff and lack of cultural support for fulfilling transparency obligations, will constrain local FOI performance (see 10.1). The following two elements explain this central political commitment.

First, the issue of openness is a recurring theme in each national Party congress since 1997. The latest CPC national congress, the $17^{\text {th }}$ NCCPC held in 2007 , went further in pronouncing on the safeguard of freedom of expression (see 4.3.2). It also stated that 'in principle, public hearings must be held for the formulation of laws, regulations and policies that bear closely on the interests of the public' ${ }^{\text {, }}$ to ensure scientific and democratic decision-making. Furthermore, the Party leader $\mathrm{Hu}$, at a visit to People's Daily in June 2008, emphasised the improvement of both time efficiency and transparency in the revelation of reliable information. ${ }^{3}$

Second, the role of openness has been improved in the State Council's reports on the work of the government to the National People's Congress (NPC) since 2004. ${ }^{4}$ In the

\footnotetext{
Paul Hubbard, 'China's Regulations on Open Government Information: Challenges of Nationwide Policy Implementation' (2008) 1 Open Government: A Journal on Freedom of Information <http://www.opengov journal.org/article/viewArticle/2651> at 22 July 2009.

2 Jintao $\mathrm{Hu}$, 'Hold High the Great Banner of Socialism with Chinese Characteristics and Strive for New Victories in Building a Moderately Prosperous Society in All Respects' (in Chinese) (Speech delivered at the $17^{\text {th }}$ National Congress of the CPC, Beijing, 24 October 2007).

3 Jintao Hu, 'Speech Delivered at the Visit to People's Daily' People's Daily (Beijing) 20 June 2008, 4.

4 Premier Wen committed in March 2004 to establishing a government information disclosure system for the first time (see 7.3.4). See Jiabao Wen, 'Report on the Work of the Government to the National People's Congress' (Speech delivered at the Second Session of the $10^{\text {th }}$ National People's Congress, Beijing, 16 March 2004).
} 
government reports of 2008 and 2009 to the NPC, Premier Wen committed to increasing transparency in government to 'create conditions to enable the people to oversee the government more effectively', 5 and to 'keep them informed as to what the government is thinking and doing, ${ }^{6}$ respectively. Premier Wen also published an article to call on government agencies to improve transparency through the implementation of the FOI Regulations and adherence to the principle that 'disclosure is the principle, while exemption is the exception', despite this principle having been omitted from the Regulations.

With the support of a strong political commitment, the State Council adopted many measures to enforce the Regulations. It has revised its Working Rules to explicitly state that the promotion of Openness in Government Affairs (OGA) is one of its core working principles. ${ }^{8}$ Furthermore, the duties of administering FOI have been allocated to the General Office of the State Council, ${ }^{9}$ which is superior to other agencies in implementing FOI legislation due to its strong coordination role and familiarity with the process of generating, obtaining and filing government information. ${ }^{10}$ The General Office of the State Council has authorised its Division I of Secretariat to be responsible for promoting and supervising compliance with the

5 Jiabao Wen, 'Report on the Work of the Government to the National People's Congress' (Speech delivered at the First Session of the $11^{\text {th }}$ National People's Congress, Beijing, 5 March 2008).

6 Jiabao Wen, 'Report on the Work of the Government to the National People's Congress' (Speech delivered at the Second Session of the $11^{\text {th }}$ National People's Congress, Beijing, 5 March 2009).

7 Jiabao Wen, 'Seriously Adhere to the Spirits of the $17^{\text {th }}$ National Congress of the CPC to Promote Vigorously the Work of Incorruptibility Construction and Anti-Corruption' (in Chinese) (2008) 9 Qiushi 3, 6. This article was based on Wen's speech at the first incorruptibility conference of the State Council on 25 March 2008 and published on 1 May 2008, the date on which the FOI Regulations took effect.

8 Working Rules of the State Council No 14 [2008] of the State Council.

$9 \quad$ Freedom of Information Regulations 2007 (China) Art 3.

10 Chaohong $\mathrm{Hu}$, 'The FOI Mechanism' in Yuchuan Mo and Hongchao Lin (eds), Interpretations of the FOI Regulations in China (2008) 89, 95; Xueshan Yang, 'Subsidiary Report on Learning FOI Regulations' (Speech delivered at Conference on Learning FOI Regulations, Beijing, 19 May 2007); It is common to see FOI offices 'set up in ministers' offices to oversee implementation and to be a nodal point in the administration' of FOI in order to ensure compliance with FOI legislation. See Oslo Governance Centre, UNDP and the Right to Information (2006) Freedom of Information Organisation <http://www.freedominfo.org/documents/Seminar_Report_-_UNDP_an d_the_Right_to_Information.pdf> at 5 September 2008. 
Regulations. ${ }^{11}$ It has already issued two notices to aid lower tiers of government to prepare and implement the FOI Regulations. ${ }^{12}$ Thus, China does not lack a high level of political and administrative leadership support for transparency, which is crucial for enforcement of FOI legislation. ${ }^{13}$

\section{Transparency advocacy groups on the supply side}

Various transparency advocacy groups on the supply side have supported the central government to ensure compliance with FOI legislation. Doubt exists about the central government's capacity to force various levels of government to comply with FOI legislation. ${ }^{14}$ Roberts states that ' $[t]$ he policy applies across the largest bureaucratic complex on the planet, and there are bound to be immense challenges in assuring that lower level officials pay attention to directions from distant Beijing'. ${ }^{15}$ Though justifiable, this concern will be lessened if the many transparency advocacy groups on the supply side in China can be recognised and given consideration. While Zhou argues that two of the previous key contributors to FOI reform - the informatisation and anti-corruption agencies - will be diminished or marginalised from promoting implementation, ${ }^{16}$ this is unlikely to occur because the FOI Regulations provide clear opportunities for them to pursue their own departmental objectives. More importantly, since the adoption of FOI legislation, several other internal agencies, such as state archives and public libraries, have involved themselves in supporting transparency for improving their departmental status. Over time, their advocacy efforts are likely to benefit the operation of FOI legislation, as appears from the following.

11 The Notice on Rules on Major Responsibilities, Divisions and Personnel Quotas of the General Office of the State Council No 60 [2008] of the General Office of the State Council.

12 The Notice on Preparing for the Implementation of FOI Regulations No 54 [2007] of the General Office of the State Council; Several Suggestions on the Implementation of the FOI Regulations No 36 [2008] of the General Office of the State Council.

13 Rick Snell, 'Administrative Compliance - Evaluating the Effectiveness of Freedom of Information' (2001) 93 Freedom of Information Review 26, 29.

14 Alasdair Roberts, Freedom of Information: From Millions to Billions (2008) Sunshine Week <http://www.sunshineweek.org/sunshineweek/roberts08> at 31 May 2008; Hubbard, above n 1, 11.

15 Roberts, above n 14.

16 Hanhua Zhou, 'Significance and Features of Introducing FOI Legislation in China' (in Chinese) (2007) 6 China Today Forum 29, 30. 
The first form of transparency advocacy comprises informatisation agencies, such as the State Council Informatisation Office (SCIO) and Leading Group on National Informatisation (LGNI). They are major contributors to the adoption of FOI legislation in China, whose interests in FOI will extend to areas closely related to informatisation development. The SCIO ceased after the government restructure plan was approved in March 2008. ${ }^{17}$ It was replaced by the Department of Informatisation Promotion under the newly restructured Ministry of Industry and Information Technology.

Though this department may not play a similar role to that previously played by the SCIO, it will continue to give guidance on the assessment of the performance of government websites that commenced in 2005, with an emphasis on online information disclosure. ${ }^{18}$ The assessment process will assist the implementation work by improving the proactive disclosure function set out in the FOI Regulations. Online proactive and reactive disclosure is the most important indicator in the assessment indicator system formed by the Ministry to evaluate the performance of government websites. ${ }^{19}$ Such performance ratings can assist the central government to accomplish the objective of using government websites as the priority platform for disseminating information. $^{20}$

The second form of transparency advocacy consists of supervisory or anti-corruption agencies which play a role similar to Ombudsmen. They will continue to promote transparency in China from a supervisory perspective. The Leading Group on

17 'The Plan for Restructuring the State Council' (in Chinese) People's Daily (Beijing) 16 March $2008,5$.

18 The informatisation agencies had commissioned China Software Testing Centre and China Centre for Informatisation Performance Assessment to evaluate the performance of government websites for four years (2005-2008). However, they would not directly commission any agencies to assess the performance of government websites in the future, only providing a key indicator system for other assessment agencies to make reference. See Xueshan Yang, Speech delivered at the Press Conference on the Seventh Assessment of the Performance of China's Government Websites, Beijing, 11 January 2009.

19 Other indicators include online business, public participation, web design and maintenance. See The Indicator System for Assessing the Performance of Government Websites in 2008 (in Chinese) (2008) The Ministry of Industry and Information Technology <http://xxhs.miit.gov.cn/n1 1293472 /n1 1295327/n1 1297217/11746784.html> at 17 March 2009.

20 The Notice on Preparing for the Implementation of FOI Regulations, above n 12. 
National Openness in Government Affairs (LGNOGA) now pays greater attention to implementation of the FOI Regulations. It held an introductory session about the Regulations at its seventh meeting in 2007 to prepare for implementation of the FOI Regulations. ${ }^{21}$ Its eighth meeting in 2008 called on state agencies to play a leading part in enforcing the Regulations. ${ }^{22}$ In 2007, it ran an awards program, awarding 123 agencies for excellent work on $\mathrm{OGA},{ }^{23}$ in addition to selecting 63 agencies as national models of implementing OGA. ${ }^{24}$ The LGNOGA also trialled the transparent operation of administrative power in Hebei in early 2005, and extended this transparent operation to elsewhere around the country after $2006{ }^{25}$

Along with the LGNOGA, the National Corruption Prevention Bureau is responsible for OGA and FOI matters. ${ }^{26}$ Furthermore, the supervision agencies, being statutory agencies having the power to accept and process complaints from the public, may play a more direct role in processing individual FOI cases to ensure compliance with FOI legislation.

The third form of transparency advocacy comprises information offices. The State Council Information Office, China's publicity department, together with spokespersons and local information offices, can improve government officials' media literacy and awareness and encourage proactivity in disclosing government information. The State Council Information Office has striven for greater transparency in government in recent years. It will continue to be a major force in

21 Yulong Li and Shaowei Wang, 'Fully Implementing the Work of Openness in Government Affairs in 2007 to Support the Openning of the $17^{\text {th }}$ National Congress of the Communist Party of China' (in Chinese) Discipline Inspection Daily (Beijing) 23 March 2007, 1.

22 Wei Xiao, 'Ensure Smooth Enforcement of FOI Regulations' (in Chinese) Discipline Inspection Daily (Beijing) 25 March 2008, 01.

23 Yajie Li, The Decision on Awarding Agencies for Their Excellent Work on Openness in Government Affairs Issued (in Chinese) (2007) Xinhua Net <http://news.xinhuanet.com/newscent er/2007-09/03/content_6657106.htm> at 6 April 2008.

$24 \quad$ Yajie Li, The Decision on Nominating National Models of Openness in Government Affairs Issued (in Chinese) (2007) Xinhua Net <http://news.xinhuanet.com/newscenter/2007-09/03/content_665 7023.htm> at 6 April 2008.

25 "Three Kinds of Openness" Record the Historical Development of Democracy and Legal Systems' (in Chinese) China Discipline Inspection Daily (Beijing) 3 September 2007, 01.

26 The National Corruption Prevention Bureau, Departments and Responsibilities of the National Corruption Prevention Bureau (in Chinese) (2007) <http://yfj.mos.gov.cn/yfj/news.jsp?mid=2007 $1109026298>$ at 5 February 2008. 
promoting more proactive disclosure. Its efforts have resulted in a wide establishment of spokesperson systems in China. ${ }^{27}$ The State Council Information Office trained about 400,000 officials to improve their media literacy and awareness in $2008 .{ }^{28}$ It has agreed to train more officials to improve government awareness of and compliance with the FOI Regulations. ${ }^{29}$

The fourth form of transparency advocacy consists of audit and environmental agencies. Audit agencies have used disclosure of audit reports as a means to promote their audit work. In 2003, the National Audit Office made a commitment to promoting disclosure of audit results. It has been the pioneer in public exposure of the problems in government, creating a series of 'audit storms ${ }^{30}$ since 2003 . Jinhua $\mathrm{Li}$, former Auditor-General of China, confessed that informing the public about audit results undoubtedly drove the Office's work. ${ }^{31}$ The current Auditor-General continued the release of audit findings, which allayed public concern about the cessation of 'audit storms'. ${ }^{32}$ The Office's continued efforts in publicising audit findings are an effective way to supervise the use of public funds.

The State Environmental Protection Bureau is another agency which has supported transparency in the performance of their functions in recent years. It published Interim Measures on Freedom of Environmental Information on 20 April 2007, four days prior to the issue of the FOI Regulations. While the Bureau focuses on the disclosure of environmental information, its efforts helps improve transparency in this area of high public interest. Yue Pan, the Deputy Minister of the Ministry of

27 The Retrospective of the 25-Year Spokesperson System (2008) Spokesmen <http://www.51 fayan. com/fyrzd25/> at 8 December 2008.

28 Chen Wang, 'Present a Real China to the World in a More Transparent Way' (in Chinese) (Press Conference, 30 December 2008).

29 Ibid.

30 Audit storms refer to 'an ongoing auditing campaign' ran by the Audit Office through making audit results public and exposing misuse or wrongful appropriation of public funds in China. See Xuan Chen and Jinchun Guo, 'Lessons from "Audit Storm" in China' (2005) 4 Chinese Business Review 1, 1-3; Jamie Horsley, 'Toward a More Open China?' in Ann Florini (ed), The Right to Know: Transparency for an Open World (2007) 54, 66.

31 Shixin Liu, 'Disclosure of Audit Results Will Be Institutionalised and Regularly in China Which Will Not Become Storms Any More' (in Chinese) China Youth Daily (Beijing) 4 November 2004.

32 'Upright Jinhua Li Left the Office with Audit Storms Still Going on' (in Chinese) Guangzhou Daily (Guangzhou) 18 March 2008, A4. 
Environmental Protection, confessed that environmental protection agencies were not powerful in China. ${ }^{33}$ The FOI Regulations therefore could better support its function. ${ }^{34}$ Zhou argues that the promotion of transparency in environmental information and the use of public funds have made environmental protection agencies and audit offices more powerful than before. ${ }^{35}$

The fifth form of transparency advocacy is the State Secrecy Bureau. The Bureau has striven to revise the Law on the Protection of State Secrets 1988 through the promotion of transparency since the late 1990s (see 6.1.2), thus indirectly facilitating the introduction of FOI legislation in China. It achieved a significant breakthrough in 2009 when the proposed revised draft of the Law was approved in principle by the State Council. ${ }^{36}$ The final step is the State Council's introduction of the revised bill to the Standing Committee of the NPC. The revision of the Law is partly to align it with the FOI Regulations, ${ }^{37}$ although whether the scope of state secrets will be narrowed or defined more clearly remains uncertain at this stage.

The sixth form of transparency advocacy consists of archives and libraries. Archivists and librarians' increasing interest in FOI legislation can provide professional support for better records management. ${ }^{38}$ This is likely to assist adherence to FOI legislation,

33 Shixin Liu, 'Yue Pan: "Environmental Protection Storms" Have Not Yet Made Environmental Agencies More Powerful' (in Chinese) China Youth Daily (Beijing) 6 April 2006, 7.

$34 \mathrm{Li} \mathrm{Ma}$, "Trade Secrets" Cannot Become the Excuse for Standard-Exceeding Emission' (in Chinese) The Beijing News (Beijing) 23 May 2007, A19.

35 Hanhua Zhou, 'The Legislative History of FOI Regulations in China' (in Chinese) (2008) $7 E$ Government 15, 17.

36 Xudong Qin, Revision of the Law on the Protection of State Secrets Accelerated (in Chinese) (2009) Caijing <http://www.caijing.com.cn/2009-04-02/110132511.html> at 11 April 2009.

37 Fengyu Xi, '12-Year Consideration of Revising the Law on the Protection of State Secret' (in Chinese) Legal Daily (Beijing) 22 July 2008, 4.

38 Jie Cheng, 'FOI Regulations and Public Libraries' (in Chinese) (2008) 4 Information and Documentation Services 16, 17; Doty argues that '[p] art of the success of FOIA ... stems from the existence of trained librarians, archivists, informatıon resource managers, and other information professionals both external and internal to government. These important intermediaries, and their professional associations, are essential to distributing government information, helping private citizens, journalists, and businesses use such information successfully, and pressuring government to be more open and responsive to the needs of the people'. See Philip Doty, Freedom of Information in the United States: Historical Foundations and Current Trends (2000) The University of Texas at Austin <www.utexas.edu/research/tipi/reports2/foia_doty.pdf.> at 8 September 2006. 
as appears from the interviews with archivists and librarians in six provinces in China. State archives are willing to implement the FOI Regulations, as they consider that this is a great opportunity for them to avoid marginalisation. ${ }^{39}$ While the work of establishing reading places in state archives confronted various difficulties, many archives had done so by 1 May 2008. The State Archives Bureau is currently planning to make efforts to revise the Archives Law 1987, partly to further clarify and intensify its role in disclosing government information. ${ }^{40}$ The success of this revision may also facilitate implementation of FOI legislation.

Public libraries, which have been granted equal statutory importance with state archives for receiving and releasing government information, are enthusiastic about implementation of the FOI Regulations to improve their roles in providing information services to the public. ${ }^{41}$ They consider government information services as an opportunity for them to reshape library services. ${ }^{42}$ The real problem is the view of government agencies, which often hold that 'the roles of libraries are not like ours' ${ }^{43}$ The National Library is currently launching an online platform to help collect and search all government information released by government websites and official publications. ${ }^{44}$ It has also called for government information to be managed more efficiently and professionally via the establishment of government printing offices, as in the US. ${ }^{45}$ Furthermore, the Standing Committee of the $11^{\text {th }}$ NPC listed Library Law in the secondary priority category of its five-year legislative plan from 2009 to

39 Interview with Archivists (Interview in Person, 1 August 2008).

40 Hong Liu, 'The Revision of the Archives Law Initiated' (in Chinese) Legal Daily (Beijing) 1 May 2007,4 .

41 Hong Liu, 'The Revision of the Archives Law Initiated' (in Chinese) Legal Daily (Beijing) 1 May $2007,4$.

42 Beijing TRS Information Technology Co., Ltd., Interview with Zhigeng Wang, Director of the Digital Resource and Service Department of the National Library (Beijing, 6 February 2009).

43 Interview with Archivists (Interview in Person, 22 July, 23 July 2008). The participants said that all library resources were openly accessed, and this made government agencies feel uncomfortable about providing government information to libraries.

44 Beijing TRS Information Technology Co., Ltd., above n 42.

45 Ibid; Zhen Cheng, Call for Establishing a Private Channel for Releasing Government Information (in Chinese) (2009) The China Law Library <http://www.chinalawlib.org.cn/LunwenShow.aspx? $\mathrm{CID}=20081224141625700185 \& A I D=20090223195302737037 \& \mathrm{FID}=20081224141208467131>$ at 4 May 2009. 
2013. ${ }^{46}$ The adoption of this Law will further clarify and strengthen the role of libraries in providing government information services.

The seventh form of transparency advocacy likely to help encourage government compliance with FOI in China is local government forerunners. China has not lacked local forerunners who experiment with new policies. The first national FOI legislation was largely based on local FOI forerunners' useful experiments (see 7.2). Local forerunners have become important references for other government agencies to follow. In 2009, the Shanghai government committed to becoming the region with the highest transparency across the country. ${ }^{47}$ Shanghai is an economically rich area. Its experiences may have been considered less useful and not transferable to other poorer areas. ${ }^{48}$ Sichuan, a poor province, has showed a much stronger interest than others in preparing and implementing the FOI Regulations since the adoption of the Regulations. ${ }^{49}$ The Sichuan case could be used to refute any future excuse of resource constraints. With the support of the central government, these local forerunners have not only accomplished relatively successful implementation of FOI legislation in their own localities, but have the potential to encourage more local governments to follow suit.

Varied supervisory agencies, directed to anti-corruption, financial or environmental inspection, have become the major forces for the implementation of FOI legislation in China. Along with supervisory agencies, some professional agencies, including informatisation agencies, state archives and public libraries, are keen to enforce FOI legislation to serve their departmental interests. The central government and these advocacy groups can pressure other government agencies to comply with FOI legislation.

46 The Legislative Plan of the $11^{\text {th }}$ Standing Committee of the National People's Congress (in Chinese) (2008) The National People's Congress <http://www.npc.gov.cn/npc/xinwen/syxw/2008 $-10 / 29 /$ content_1455985.htm $>$ at 31 October 2008.

47 The Shanghai Government, Freedom of Information Rules 2004 Annual Report 2008.

48 Hubbard, above n 1, 19; Interview with Chinese government officials (24 June 2008, 23 July 2008).

49 The General Office of the State Council, Preparation for Implementation of FOI Regulations in Sichuan Was Tremendously Effective (in Chinese) (2008) The Central Government <http://www. gov.cn/zfjs/2007-09/18/content_753799.htm> at 19 March 2009. 


\subsubsection{The supply side: capacity to implement FOI legislation}

The Chinese government's capacity to comply with FOI legislation can arguably be derived from the changed technological, political, legal, economic and civil service conditions. The ongoing development of democracy, the rule of law and the professional civil service, together with increased economic power and improved records management, has likewise created capacity to assure compliance with FOI legislation in China.

\section{Improving technological conditions}

Increasing volume of electronic records and a wide launch of government websites have improved information flow (see 3.2.3), thus facilitating compliance with FOI legislation. The following two aspects are important. First, record keeping practices in China are improving. The central informatisation agencies have assisted the Chinese government to realise the importance of information management. They circulated a document, titled 'Suggestions on Strengthening the Exploitation of Information Resources, ${ }^{50}$ in 2004 , which stated that information resources enjoyed equal importance with energy and material resources and played an irreplaceable role in developing the economy. ${ }^{51}$ They urged the improvement of government information management through institutionalising the collection, register, maintenance, release and classification of government information. ${ }^{52}$ China, a newcomer to the FOI family, also recognises record management as indispensable to

50 Suggestions on Strengthening Exploitation and Use of Information Resources No 34 [2004] of the General Office of the CPC Central Committee.

51 Ibid.

52 Ibid. 
an access regime. ${ }^{53}$ This is demonstrated by the requirement for government agencies to produce and publish information inventories and guides. ${ }^{54}$

It follows that records management should not be a major source of concern over compliance with FOI legislation. ${ }^{55}$ In 2008, the General Office of the State Council circulated an interim directive to guide the compilation of FOI inventories. ${ }^{56}$ In addition, FOI legislation has created incentives for professional record keeping agencies, including archives and libraries to involve themselves in promoting FOI, which will improve information management in China and facilitate implementation (see 9.1.1).

Second, the launch of a wide number of government websites can help reduce the use and importance of access requests (see 3.2.3). China has an opportunity to design its FOI legislation to make full use of the advantage of information technology. ${ }^{57}$ This has resulted in China's FOI legislation taking a push model that focuses on proactive disclosure. This push model can reduce the number of individual requests. Furthermore, government agencies have launched FOI sections, online searching and information requesting on their official websites to provide government information services in a holistic way.

\section{Improving political conditions}

The longstanding democratisation efforts show that FOI legislation can be implemented in China. Many years of grassroots democracy experiments have presented the opportunity for local governments to familiarise themselves with

53 Sebina argues that new FOI adopters should consider records management as 'an integral part of the access regime rather than an afterthought or an optional extra'. See Peter Sebina, Freedom of Information and Records Management: A Learning Curve for Botswana (D Phil Thesis, University College London, 2006) 185.

54 Yangwu Ou, Speech delivered at Seminar on the FOI Regulations, Beijing, 17 March 2007. See http://www.hongfan.org.cn/file/upload/2007/03/17/1215097825.pdf.

55 Hai Qin, Speech delivered at Seminar on the FOI Regulations, Beijing, 17 March 2007. See http://www.hongfan.org.cn/file/upload/2007/03/17/1215097825.pdf.

56 The General Office of the State Council, Freedom of Information Regulations 2007 Annual Report 2008.

57 Email from Paul Hubbard to Weibing Xiao, 18 May 2008. 
openness (see 4.2). The work of OGA which emphasises proactive disclosure has been accepted by all levels of government as an integral part of the framework of administration. ${ }^{58}$ Thus, compliance with FOI legislation will not necessarily imply a revolution in the work practices of low levels of government. Implementation of FOI legislation for lower tiers of government is largely a project that continues and extends their previous openness practices (see 7.1). This will lessen the concern over the central government's capacity to force local governments to comply with the FOI Regulations.

The central government has regarded deliberative democracy as a vital form of socialist democracy since early 2006 (see 4.1.2). This increased transparency in decision-making. Democratic decision-making, which lies at the core of deliberative democracy, has been considered an overarching task of the Hu-Wen Administration (see 4.3.1). This has made public consultation, by keeping the public informed or holding hearings, a common feature of significant policy decisions. ${ }^{59}$ Significant policy changes now generally do not come as a surprise to the public, who have been informed in advance through various measures, including consultation with experts and public participation (see 9.2.3). ${ }^{60}$

\section{Improving legal conditions}

China's gradual strengthening of the rule of law, which may allay concerns over China's bureaucracy to impede compliance with FOI legislation. The rule of law has been accepted and considered by the Chinese government as a ruling principle (see 5.1.2). Furthermore, administrative law is now associated with government transparency, as the recent administrative law reforms have emphasised ex ante and procedural controls of government power (see 5.2.4). A government under the rule of law, a key part of the rule of law plan, has also become a clear goal of the Chinese

58 Yong He, 'The Speech of Yong $\mathrm{He}$ at the Eighth Meeting of the Leading Group on National Openness in Government Affairs' (Speech delivered at Beijing, 24 March 2008).

59 Working Rules of the State Council No 14 [2008] of the State Council; The Decision of the State Council on Strengthening Administration by Law in the Municipal and County Governments No 17 [2008] of the State Council.

60 Working Rules of the State Council No 14 [2008] of the State Council. 
government to accomplish by 2014.FOI legislation serves as a key part of achieving this long term law reform process (see 5.3).

\section{Rising economic power}

China's rising economic power during the last three decades will enable the Chinese government to comply with FOI legislation, especially from the supply side perspective. China has increased its comprehensive national strength, and is not the same country as it was three decades ago (Appendix 7). This indicates that China has the capacity to afford the necessary costs of administration of FOI legislation. Indeed, the Chinese government has few worries about the costs of implementing this legislation (see 6.2.2), even in the face of wide regional disparities in economic growth. Moreover, the high costs in processing access requests have been reduced by the Chinese government's emphasis on proactive disclosure, and use of new technologies to release government information in a holistic way.

\section{Improving professional civil service}

Professional civil service in China has been improved in a variety of ways, which may assist the implementation of FOI legislation. The implementation may be assisted in three ways. First, an institutional framework of a personnel system has been formulated. Interim Regulations on National Civil Servants were adopted in 1993 to establish a personnel management system in China for the first time. These were upgraded to the Civil Servant Law in 2005. Other accompanying rules were also introduced to improve the personnel system in China, ${ }^{61}$ combining to form the institutional framework of the personnel system. ${ }^{62}$

61 Such as Regulations on the Work of Selecting and Appointing Leading Party and Government Cadres 2002, Provisional Regulations on the Open Selection of Leading Cadres of the Party and Government 2004, Interim Rules on the Tenure System of Leading Cadres of the Party and Government 2006, Rules on the Intercommunication System of Leading Cadres of the Party and Government 2006.

62 'The Institutional Framework of the Personnel System Has Been Formed on a Preliminary Basis' (in Chinese) (2006) 32 Information for Deciders 7, 7. 
Second, permanent jobs or iron rice bowl (Tie Fan Wan) in the public service have ceased. The procedures and conditions for civil servants' resignation and dismissal were regulated in 1995 for the first time. The Civil Servant Law 2005 further legislates on these. While only a small number of civil servants resigned or were dismissed in the past, ${ }^{63}$ government agencies are now staffed by individuals who move in and out of government. This will likely diminish the habit of government secrecy. ${ }^{64}$

Third, the quality of professional personnel has increased. The three-decade pursuit of younger, more educated and professional staff has succeeded. ${ }^{65}$ More than 35 percent of civil servants now have undergraduate diplomas or above. ${ }^{66}$ Fourth, a training system has been established ${ }^{67}$ improving public service professionalism. The State Council Legislative Affairs Office the conducted six training sessions in 2007, and trained about 3000 attendees from various government agencies for the implementation of the FOI Regulations. ${ }^{68}$ Local governments also trained their own staff. FOI has now been included in the training courses for civil servants, indicating that all civil servants will receive FOI training in the future. ${ }^{69}$

63 Between 1996 and 2003, more than 40,000 civil servants, accounting for about 0.8 percent, resigned or were dismissed. See $A$ Summary of the Work of Civil Servants' Resignation and Dismissal (in Chinese) (2003) China Net <http://www.china.com.cn/chinese/zhuanti/gwy/385982. htm> at 11 March 2009.

64 The idea belongs to John McMillan, the Australian Commonwealth Ombudsman. See John McMillan, 'Twenty Years of Open Government: What Have We Learnt?' (Law and Policy Paper No 21, The Federation Press, 2002) 7-8.

65 Deng argued in 1980 that 'we should see to it that our cadres are younger on the average, better educated and better qualified professionally'. See Xiaoping Deng, Selected Works of Xiaoping Deng (Volume II) (in Chinese) ( $\left.2^{\text {nd }} \mathrm{ed}, 1994\right) 326$.

66 Thirty-Year Reform of the Cadre of Personnel System Overviewed by the Ministry of Personnel with Three Phases (in Chinese) (2008) China Net <http://www.china.com.cn/news/txt/200804/11/content_14937807.htm > at 14 April 2008. The percentage in 1977 was only 18 percent.

67 Ruowei Sheng, Interview with the Ministry of Personnel (Beijing, 12 August 2003).

68 The Notice on Training Sessions for FOI Regulations [2007] of the Legislative Affairs Office of the State Council.

69 The Notice on Preparing for the Implementation of FOI Regulations No 54 [2007] the General Office of the State Council. It required local governments to list FOI as a training course for civil servants. 


\subsection{The supply side: compliance with proactive disclosure in practice}

Various supply side transparency advocacy groups and interested citizens, along with the central government, have become the main forces of implementing China's FOI legislation. As a result, relative success has been achieved by holding the government to the proactive disclosure requirements under FOI legislation. This compliance means that government agencies themselves implement proactive disclosure requirements without access requests serving as reminders. Government agencies have followed the fundamental criteria under the FOI Regulations to decide which information is required to be proactively disclosed. They have actively distributed the information involving the vital interests of the public so as to win public support. They have also proactively disclosed government information, which has aided public participation and improved policy outcomes. In addition, government agencies at various levels have actively released standard information about their administrative organisation, function and working procedures.

\subsubsection{Proactive disclosure of crisis information: protecting the vital interests of the demand side}

The FOI Regulations prescribe four general criteria for government agencies to decide which information is required to be disclosed actively (see 8.2) ${ }^{70}$ Assessment of the enforcement of these four criteria can capture the reality of government compliance with the proactive disclosure duty, especially the first three criteria. The fourth one is a residual criterion designed to cover proactive disclosure requirements under other laws and regulations. The first criterion is information that involves the vital interests of the demand side. ${ }^{71}$ The thesis uses disclosure of crisis information as a key lens to explore government compliance with this criterion. It reveals that the Chinese government has proactively disclosed a wide range of crisis information since the adoption of the FOI Regulations. Release of prompt and accurate crisis

$70 \quad$ Freedom of Information Regulations 2007 (China) Art 9.

71 Freedom of Information Regulations 2007 (China) Art 9. 
information was a focus in $2008,{ }^{72}$ improving information flow in China. The following three aspects substantiate this statement.

First, the Chinese government has become more transparent and active than before in dealing with natural disasters. The snow crisis ${ }^{73}$ and the Sichuan earthquake ${ }^{74}$ provide two striking examples that contrast with the government's response to the Severe Acute Respiratory Syndrome (SARS) crisis. In the snow crisis, the government disclosed information in 'a very open way'. ${ }^{75}$ The release of information on the Sichuan earthquake, which occurred only 12 days after the FOI Regulations took effect, was impressive and highly praised by non-Chinese. ${ }^{76}$ After the earthquake, Premier Wen made the commitment that 'we will never change our transparent policy, and once there exists an epidemic, we will promise to process it in an open way'.77 This commitment aligns the shift from a secretive and reactive approach to crisis information management toward a transparent and proactive approach (see 3.2.3).

72 Wang, above $\mathbf{n} 28$.

73 In January 2008, the south of China experienced snowstorms that resulted in millions of people being incapable of returning home to celebrate the traditional Chinese New Year. Many cities suffered blackouts and water shortages for a week. The government promised that it would disclose prompt information to win public support. See Rare Snow Storms in China's 10 Provinces and Has Lasted for Half a Month with 32.87 Million People Being Caught up (in Chinese) (2008) China News <http://www.chinanews.com.cn/gn/news/2008/01-26/114672 7.sh tml> at 15 April 2008.

74 On 12 May 2008, a magnitude 8.0 earthquake took place in Sichuan Province. The death toll amounted to 69,000 , with another 18,000 missing. The government allowed national and international media groups to report this disaster extensively and rapidly. The death toll was updated and disclosed to the public regularly. The National Earthquake Bureau released the information on this massive earthquake to the public only 18 minutes after the outbreak. China Central Television and some local TV stations provided 24-hour coverage of the disaster to give live reports. See Zongjin $\mathrm{Ma}$ and Peijun Shi, 'Issues on May 12 Wenchuan Earthquake and Damage Evaluation' (in Chinese) (Press Release, 4 September 2008); Han Han, 'Transparency in Earthquake Information as a Tool for Maintaining Social Order' (in Chinese) The Economic View (Zhengzhou) 15 May 2008, A04.

75 Peter Ford, 'This Time, Beijing's Disaster Response Is Open, Sensitive' Christian Science Monitor (Boston) 4 February 2008, 6.

76 A CNN journalist states that '[t]oday's more open, quick and aggressive reporting is a stark departure from China's poor performance in recent years'. Jaime FlorCruz, China's Government Gives Rare Transparent Look at Disaster (2008) CNN <http://www.cnn.com/2008/WORLD/asiap cf/05/15/florcruz.china/ $>$ at 22 May 2008; George Yeo, the Foreign Minister of Singapore, argues that the transparent way in which China released the information on the earthquake is 'novel' and 'incredible'. See Sim Chi Yin, China's Handling of Quake News 'Novel' (2008) The Straits Times <http://www.straitstimes.com/Free/Story/STIStory_238121.html> at 17 May 2008.

77 Jiabao Wen, 'Jiabao Wen Meets with UN Secretary-General Ban Ki-moon in the Quake-Hit Area' (Press Release, 24 May 2008). 
Second, the Chinese government has become more open and active in releasing the information about various mass incidents, such as the taxi strikes in Chongqing ${ }^{78}$ and the riots in Gansu. ${ }^{79}$ Government officials recognise that active disclosure of massive accidents is important, confessing that 'in today's Internet era, hiding things does not help', ${ }^{80}$ and 'will only make things worse'.

Third, the Chinese government has proactively disclosed information regarding public safety in a timely manner, as the rail disaster in Shandong ${ }^{82}$ and a subway tunnel collapse in Zhejiang ${ }^{83}$ have demonstrated. Fourth, the Chinese government has proactively disclosed information regarding public health to counter rumours, such as information concerning food safety. The crises of pork in Beijing ${ }^{84}$ and banana contamination in Hainan ${ }^{85}$ illustrate this active disclosure approach.

78 After about 8000 taxi drivers in Chongqing went out strike in the morning of 3 November 2008, the media released this information at noon. The Chongqing government held four press conferences about this strike during the next two days. On 6 November, the Party Secretary Xilai Bo and other government officials arranged an open discussion with taxi drivers, citizens and other representatives, which was allowed to broadcast live by the media. See Weiao Li and Hai Deng, Chaotic Taxi Strike Pays off in Chongqing (in Chinese) (2008) Caijing <http://english. caijing.com.cn/2008-11-15/110028781.html> at 2 December 2008.

79 On 17 November 2008, up to 2000 residents attacked the party headquarters of the city of Longnan in Gansu Province in protest against a government resettlement plan. The Party newspaper, Gansu Daily, released this news in the morning of 18 November. The Longnan Government held a press conference on this riot the same day. See 'A Massive Incident Occurred in the Wudu District of the Longnan City' (in Chinese) Gansu Daily (Lanzhou) 18 November 2008,1 .

$80 \mathrm{Li}$ and Deng, above $\mathbf{n} 78$.

81 Ibid.

82 In the morning of 28 April 2008, China's worst rail disaster in a decade occurred in Shandong Province which resulted in 72 fatalities and 416 injuries. This accident was caused by the derailment of railway train T195 and collision with another train. The earliest news report was publicised only 4.5 hours after the crash. The death toll was reported at noon and the reason for this accident was released in the afternoon. See There Were 72 Killed in Train Collision in Shandong (in Chinese) (2007) 163.com <http://news.163.com/08/0503/00/4AVRQBG40001 124J. html $>$ at 3 May 2008.

83 A subway tunnel collapse occurred in the city of Hangzhou in Zhejiang Province on 15 November 2008, causing 17 deaths and four missing. The Hangzhou government held a press conference to release the information on this crisis the same day. More than 70 media groups were allowed to air this accident live. The Hangzhou government made a commitment that it would disclose this accident in an open, true and timely manner. See Shuang Yuan and Yun Jiang, The Hangzhou Subway Collapse: The Party Secretary Calls for Eight Requirements (in Chinese) (2008) China News <http://www.chinanews.com.cn/gn/news/2008/11-16/1451030.shtml> at 3 December 2008.

84 In January 2007, the Beijing government noticed a rumour spreading through SMS text messages that said 'don't eat pork! Pork in Beijing has been contaminated by a virus that can cause 
There are some negative cases, like the scandal of baby milk power contamination. ${ }^{86}$ These cases prove that information release is important to manage crises efficiently. This scandal resulted in senior officials resigning or being dismissed for their concealment. ${ }^{87}$ Government officials accordingly paid a high price for their concealment. After this scandal, the new leadership of the Shijiazhuang government conducted an extensive training session to improve the capability to release crisis information. $^{88}$

\subsubsection{Active distribution of information: encouraging public participation}

The second criterion for proactive disclosure under the FOI Regulations is information that needs to be extensively known or participated in by the general public. ${ }^{89}$ The Chinese government has undertaken unprecedented proactive disclosure practices since the passage of the FOI Regulations to facilitate wide public participation and debates. These practices did not occur coincidently with the adoption of FOI legislation, but were part of the activities to comply with FOI legislation.

pyogenic encephalitis'. The Bureaus of Health, Agriculture and Public Security immediately released the accurate information to deny this rumour. See No Pork Meat Disease Outbreak in Beijing: Health Official (2007) People Net <http://english.peopledaily.com.cn/200701/14/eng200 70114_341068.html $>$ at 2 August 2008.

85 After the rumour said that bananas grown on Hainan contained viruses similar to SARS spread around China by text messages in May 2007, the Ministry of Agriculture countered this rumour, stating that 'it is purely a rumour and it is impossible for bananas to contain SARS-like viruses'. See China Central Television, 'The Ministry of Agriculture Denied the Rumour Saying That Bananas Had Viruses Similar to SARS' News $360^{\circ}, 23$ May $2007<$ http://vsearch.cctv.com/plgs_ play.php?ref=cctvcomprog_20070523_1506487> at 2 December 2008.

86 In September 2008, the company Sanlu, which was based in the city of Shijiazhuang, was found to produce baby milk powder contaminated by melamine. The Shijiazhuang government undertook a secretive and reactive approach to respond to this crisis, and tried to conceal this contamination and sent a late report to the superior government. This approach caused the government the loss of valuable time to deal with the crisis. See 'The Shijiangzhuang Government Apologised for the Sanlu Milk Power Scandal' (in Chinese) Nanjing Daily (Nanjing) 1 October 2008, A01.

87 Changjiang Li (the Minister of the General Administration of Quality Supervision, Inspection and Quarantine) resigned for this contamination scandal. Xianguo Wu (the Party Secretary of the CPC Shijiazhuang Municipal Committee) was dismissed. Mayor Chuntang Ji and Vice Mayor Fawang Zhang as well as three other responsible city officials were sacked.

88 Ruiqian Zhang, 'Strengthening Guidance of Public Opinion to Improve the Ruling Capability' (in Chinese) Yanzhao Evening (Shijiangzhuang) 15 December 2008, A3.

89 Freedom of Information Regulations 2007 (China) Art 9. 


\section{Willingness to actively release environmental information}

The Chinese government has actively released information on environmental impact assessment to encourage public participation. Such information disclosure was first institutionalised by Interim Measures for Public Participation in Environmental Impact Assessment 2006. ${ }^{90}$ It was strengthened after the adoption of the FOI Regulations, as an aim of the Regulations and one general criterion are to encourage public participation. ${ }^{91}$ The first widely known case of environmental information release, which occurred in 2007, related to the Xiamen city Paraxylene plant project. ${ }^{92}$ Another occurred the same year, relating to a Maglev construction project in Shanghai. ${ }^{93}$ These events were an indirect result of implementing the FOI Regulations as they occurred before the Regulations came into force. However, they have marked a significant step in releasing information on environmental impact assessment in China, and caused other government agencies to follow suit, such as

90 Interim Measures for Public Participation in Environmental Impact Assessment 2005 (China) Art 7.

$91 \quad$ Freedom of Information Regulations 2007 (China) Art 1, Art 9.

92 The Xiamen city Paraxylene plant project was not subject to the Interim Measures for Public Participation in Environmental Impact Assessment as the project was approved before the Measures became effective. However, Xiamen citizens pressured the government, arguing that this project contributed to pollution and was potentially dangerous. Under pressure, the Xiamen government agreed to release the environmental assessment information and seek public comments. After extensive interactive communications with the citizens via an online survey and two public hearings, the government found that about 90 percent of the citizens resisted this project. As a result, the Xiamen government planned to move this controversial project to another more suitable city. See Hongjun Zhu, 'The Xiamen Government's Consideration of Public Participation' (in Chinese) Southern Weekend (Guangzhou) 20 December 2007, A01; Hongjun Zhu, "I Will Fight to Death for Your Right to Say It" - Full Transcripts of Public Hearings about the Xiamen Paraxylene Project Environmental Impact Assessment' (in Chinese) Southern Weekend (Guangzhou) 20 December 2007, A02.

93 In late 2007, a proposed Maglev train route and an environmental impact assessment of the Maglev construction project were posted on government websites to seek public comments. This information was also released to concerned residents after they questioned the convenience of accessing it. Residents worried that the new Maglev train would bring about noise pollution and possibly dangerous radiation. They thus took part in a harmonious walk to oppose this project. This event resulted in the suspension of the Maglev construction. See Kai Zhou, 'The Proposed Shanghai Maglev Construction Project Available for Public Opinion' (in Chinese) China Youth Daily (Beijing) 14 January 2008,7; Wenjie Zhang, 'Introduction on Shanghai Major Construction Projects in 2008' (in Chinese) (Press Release, 19 March 2008). 
Guangdong. ${ }^{94}$

\section{Willingness to proactively disclose information on decision-making}

Public participation has played a more valuable role in Chinese legislative processes, aiding China to develop deliberative politics. The NPC, China's top legislature, and the State Council have become more transparent in publishing draft bills or administrative regulations, especially those closely involving the interests of the general public (see 5.2.4). Apart from this, the Chinese government has become more open in key decision-making closely related to public interest. After the FOI Regulations entered into force, information on several key decisions, such as the readjustment of public holidays, ${ }^{95}$ reforms of fuel taxation and pricing mechanisms, ${ }^{96}$ and health care, ${ }^{97}$ was proactively disclosed by the government to let the public know and comment on it.

Furthermore, public participation in decision-making, especially rule-making, has become more convenient once many legislative affairs offices and other government

94 In March 2008, after the central government approved a $\$ 5$ billion oil refinery project in Guangdong province, senior officials in this province were also committed to disclosing the environmental impact assessment of this project and seeking public comments on it. See Shuangyue Tian and Hua Xin, 'Public Hearings will be Held for the Guangdong Oil Refinery Project' Southern Metropolis Daily (in Chinese) (Guangzhou) 11 March 2008, A09.

95 On 9 November 2007, the National Development and Reform Commission released its proposed readjustment of public holidays and conducted its online survey through the most widely known websites in China, including sina.com, sohu.com and people.com. About 1.55 million netizens took part in this survey, and more than 80 percent of them showed their support for this readjustment. The State Council adopted new rules on public holidays on 14 December 2007 after considering public comments. See Wei Liu, 'Eighty Percent of Netizens Support the Readjustment of Public Holidays' (in Chinese) Beijing Times (Beijing) 16 November 2007, 2.

96 The Chinese government released its draft plan for health care reform to collect public comments between 14 October and 14 November 2008. This reform aims at providing universal medical service to all Chinese people. 27,892 comments were left on the National Development and Reform Commission website after public debates were completed. See The National Development and Reform Commission, Public Notice on Openly Soliciting Comments on 'Opinions about Deepening China's Healthcare Reform [Draft for Input]' (in Chinese) (2008) <http://shs.ndrc. gov.cn/yg/qianyan/t20080401_202368.htm> at 15 December 2008.

97 The National Development and Reform Commission and three other authorities publicised a draft scheme on fuel taxation and reform of the refined oil pricing mechanism to solicit public comments between 5 December and 12 December 2008. See The National Development and Reform Commission, The National Development and Reform Commission and other Authorities Publicised the Draft Scheme on Fuel Taxation and Reform of the Refined Oil Pricing Mechanism to Seek Public Comments (in Chinese) (2008) <http://www.ndrc.gov.cn/xwfb/t20081205_250290. $\mathrm{htm}>$ at 8 December 2008. 
agencies launched online systems for seeking public opinions on drafts of administrative regulations and rules. ${ }^{98}$

\subsubsection{Proactive disclosure of standard information: facilitating public supervision}

The third criterion for proactive disclosure under the FOI Regulations is standard information about government agencies' structure, functions and working procedures. ${ }^{99}$ Government agencies had few difficulties in disclosing this category of information; its disclosure commenced before the FOI Regulations were adopted. This disclosure may be viewed from the perspective of the facilitation of democratic supervision by ordinary citizens. After government agencies had proactively disclosed their number of leadership positions on official websites, Chinese netizens or Internet users had the opportunity to discover and question the pervasive and longstanding overstaffing issue. A netizen's post in November 2008 about the overstaffing problem of the Tielin government stimulated other netizens to discover similar issues in government agencies from official websites. ${ }^{100}$ As a result, the disclosure of the size of leadership positions sparked heated discussion on the Internet. Many called for a reduction in the number of deputy leadership positions. The central government did not ignore this increasing public opinion. It circulated a notice in January 2009 to require local governments to standardise the quotas of

98 The State Council Legislative Affairs Office first launched this online system in 2007. Ting Hou et al, 'On the Construction of an Online Information System for Seeking Public Opinions on Drafts of Administrative Rules' (in Chinese) (2008) 7 E-Government 90, 90-3. Other legislative affairs offices, such as Shanghai and Shandong, followed suit.

99 Freedom of Information Regulations 2007 (China) Art 1.

100 In late November 2008, a netizen learnt from the official website of the Tielin government in Liaoning Province that this local government, only responsible for about 3.04 million citizens, had nine deputy mayors and 20 deputy secretary-generals. He then posted this fact to the Internet. See Jinjin Guo and Wei Liu, 'Twenty Deputy Secretary-Generals in the Tielin Government Sparked Heated Discussion' (in Chinese) Chengdu Business Daily (Chengdu) 27 November 2008, 7; A netizen revealed that there were 11 deputy mayors and 16 deputy secretary-generals in the Xinxiang government in Henan Province. See Kecheng Li and Yurong Wu, 'Eight Deputy Mayors in Xinxiang Did not Exceed Personnel Quotas' (in Chinese) Oriental Morning Post (Shanghai) 3 December 2008, A20. A netizen revealed that the Pingjiang government in Hunan Province had 10 vice county magistrates and four magistrate assistants. Pingjiang is a natıonal poverty county. See Yifu Deng, 'Ten County Deputy Mayors in the Pingjiang County of Hunan Province' (in Chinese) New Express Daily (Guangzhou) 4 December 2008, A26. 
assistants and deputy secretary-generals. ${ }^{101}$

Ordinary citizens could not have known about this overstaffing issue without proactive disclosure of leading posts on the Internet. The online discussion about overstaffing issue demonstrates that all streams of information flows are correlative (see 2.3). Previously, the improvement in informant flow among citizens caused the Chinese government to become more proactive in disclosing government information (see 3.2.3). Today, the improvement in proactive disclosure of government information has enhanced the capacity of Chinese citizens to use, distribute and analyse the information.

\subsection{Review systems: increasing the capacity of the demand side to redress non-compliance with proactive disclosure}

The increasing willingness and capability of supply side players have resulted in much government information being proactively disclosed by government agencies themselves (see 9.2). The level of compliance has further increased because government agencies have rectified their non-compliance with proactive disclosure requirements since active players on the demand side pressure government agencies to implement the requirements. Rights activists, legal professionals and interested citizens, who represent major players on the demand side, have the capacity to redress government non-compliance with proactive disclosure. This is because the current internal and external review systems are capable of supporting their lawsuits against this non-compliance.

\subsubsection{The administrative reconsideration system}

Administrative reconsideration has increased demand side players' capacity to call on government agencies to disclose information required to be actively released. Applications for administrative reconsideration are generally processed by legislative

101 The Notice on Standardising the Quotas of Assistants and Deputy Secretary-Generals at the Local Level No 3 [2009] of the Organisation Department of the CPC Central Committee. 
affairs offices. Two striking cases related to the enforcement of local FOI Rules and occurred before the FOI Regulations came into effect. The first is the Chen case, ${ }^{102}$ which occurred in Guangdong Province in early 2006. Chen submitted a number of applications for administrative reconsideration to prompt local government agencies to reconsider their transparency policies. The second, the Huang case, ${ }^{103}$ occurred in Hubei Province. Huang filed a series of administrative reconsideration to call on government agencies to redress their non-compliance with online information disclosure. Both Chen and Huang won their support from administrative reconsideration agencies, causing government agencies to correct their noncompliance activities.

The $X u$ et al case $\mathrm{e}^{104}$ is a significant case occurred after the FOI Regulations came into effect. On 26 May 2008, Yaofang Xu and 67 other villagers filed a request to the Yuyao Government in Zhejiang Province for more details about the transfer of

102 In early 2006, Shuwei Chen, a consumer rights activist, sent his requests to 37 government agencies in Guangdong Province for information that is required to be proactively disclosed, such as details of major leaders and the allocation and use of special financial funds. Many government agencies did not reply to Chen. He then submitted 37 applications for administrative reconsideration. The Guangdong Legislative Affairs Office consulted with Chen after noticing Chen's series of applications, and it finally persuaded him to withdraw all his applications. Although Chen did not get the information requested, he prompted local government agencies to reconsider their transparency policies. The Office said that the Chen case taught a lesson to Shenzhen government agencies, and forced them to become more transparent. Chen also submitted his requests to several government agencies in the city of Zhuhai in Guangdong Province for similar proactively disclosed information. Although his requests were refused, he won support from the administrative reconsideration agency - the Zhuhai government. See The Guangdong Legislative Affairs Office, A Series of Administrative Reconsideration Cases Solved Successfully in Shenzhen (in Chinese) (2006) China Legislative Information Network System $<$ http://www.chinalaw.gov.cn/jsp/contentpub/browser/contentpro.jsp?contentid=co2381312326> at 7 June 2007; The Decision of Administrative Reconsideration Made by the Zhuhai People's Government No 8 [2006] of the Zhuhai People's Government.

103 After the city of Wuhan brought its FOI Rules into effect in 2004, Zhihong Huang, a foremost combatant against deceptive advertising, sent 16 applications in 2005 to government agencies demanding that they should publicise FOI inventories on their official websites. After he had not received any reply from 10 agencies, he filed administrative reconsideration against them. His administrative reconsideration attracted the attention of the Wuhan Legislative Affairs Office which called on these agencies to comply with their proactive disclosure duty. These agencies finally disclosed their FOI inventories on their websites. See Lei Yang, A Citizen Requested Government Information from 10 Agencies and Achieved Success with the Support of the Wuhan Legislative Affairs Office (in Chinese) (2005) The Wuhan Legislative Affairs Office $<$ http://www.whfzb.gov.cn/Article,868.html>at 21October 2008.

104 Junxiu Wang, 'Sixty-Eight Villagers in Yuyao City of Zhejiang Province Won Their FOI Lawsuit' (in Chinese) China Youth Daily (Beijing) 10 October 2008, 6. 
approximately half of the total lands of their village. After receiving no response from the Yuyao Government, they applied for administrative reconsideration to the Ningbo Government, which required the Yuyao Government to handle this request pursuant to the FOI Regulations. This case won support from the administrative reconsideration agency, indicating that administrative reconsideration agencies have the capacity to help redress government non-compliance with proactive disclosure requirements.

Furthermore, a current pilot project has the capacity to intensify demand side players to rectify non-compliance with proactive disclosure. The State Council Legislative Affairs Office decided in September 2008 to experiment with a new administrative reconsideration mechanism in eight provinces, aiming to establish a more centralised, professional and impartial administrative reconsideration mechanism to process administrative reconsideration applications. ${ }^{105}$ Administrative reconsideration committee consisting of experts, scholars and government officials were also established in these provinces. This pilot project will help process increasing administrative reconsideration applications for FOI decisions. ${ }^{106}$

\subsubsection{The administrative lawsuit system}

The capacity of demand side players to redress government non-compliance with proactive disclosure has increased, as Chinese courts have supported the lawsuits against non-compliance. In the $X u$ case, the court adjudged the Bureau's mute refusal illegal. This judgment was the first FOI lawsuit supported by the court after the FOI Regulations came into effect. ${ }^{107}$ The Hubei Provincial Legislative Affairs Office

105 The Notice on the Pilot Project for Developing the Administrative Reconsideration Committee in Several Provinces and Special Municipalities No 71 [2008] of the Legislative Affairs Office of the State Council.

106 Between 1 May 2008 and 31 December 2008, 881 applications were made for administrative reconsideration of agency decisions on access requests in 17 provinces. The total number is greater than this. The number is likely to increase in the future.

107 Jianguo $\mathrm{Xu}$, a Beijing lawyer, filed a request dated 1 May 2008 to the Huangzhou District Bureau of Transport for some proactively disclosed information concerning this Bureau's structure, function and working procedures. The Bureau did not answer Xu's request. Xu thus brought the Bureau to court on 2 June. His action won support from the court. See Doudou Tian, 'The 
issued a bulletin to inform all government agencies of this non-compliance, calling on government agencies to comply with the Regulations. ${ }^{108}$ An official in this Office questioned 'why the agency has not disclosed the information until the masses take it to court'. ${ }^{109}$ The bulletin has the potential to create positive effects on the enforcement of FOI legislation.

This was not the only lawsuit upheld by courts. In the Zhou case, ${ }^{110}$ the government did not answer Zhou's request for a building dismantlement licence and other necessary legal documents until he initiated court action. In the Xie case, ${ }^{111}$ the government did not release the documents regarding subsidies for breeding pigs to Xie until the court actively mediated in the dispute.

Along with administrative reconsideration agencies, Chinese courts have bolstered compliance with proactive disclosure requirements under the FOI Regulations. In the long run, courts will likely play a more positive role in ensuring compliance with the proactive disclosure requirements under the Regulations.

\subsubsection{The reporting system}

A reporting mechanism is preferable to an administrative lawsuit and reconsideration in systematically redressing non-compliance with proactive disclosure requirements

Government Agency Lost Its FOI Lawsuit for the First Time' (in Chinese) People's Daily (Beijing) 10 October 2008, 10.

108 Chaoxin Chu, 'The Hubei Government Issued a Bulletin on the Government's First Failure in Relation to FOI Lawsuits' (in Chinese) The Beijing News (Beijing) 11 October 2008, A13.

109 Ibid.

110 On 4 May 2008, Zhou, the head of a relocated household, filed a request to the Rugao Construction Bureau of Jiangsu Province for a building dismantlement licence and other necessary legal documents, which were in the category of proactively disclosed information set out in the FOI Regulations. The government did not answer his request until he took it to court. See Hong Chen et al, The First FOI Lawsuit in Nantong City Was Finalised (in Chinese) (2008) The Rugao Government <http://www.rugao.gov.cn/html/2008/08/20080818094116-1.htm>at 20 October 2008.

111 Xie, a farmer, applied to the Xuchang Development and Reform Commission for policy documents regarding subsidies for breeding pigs on 16 June 2008. Xie took the Commission to court for its mute refusal. The court supported Xie's action, and held that the Commission had the duty to disclose the policy documents sought. The Commission finally gave these documents to Xie after the court actively mediated in this dispute. See Zhong $\mathrm{He}$ and Jinli Pu, 'The First FOI Lawsuit in Henan Province Reached out of Court Settlement' (in Chinese) Workers' Daily (Beijing) 28 August 2008, 6. 
in China. ${ }^{112}$ Han reported several central government agencies' failure to disclose national standards to the State Council in May 2008. ${ }^{113}$ His complaints received a response by the State Council, which called on government agencies to rectify their malpractice. ${ }^{114}$ The Ministries of Health, and Housing and Urban-Rural Development rectified their improper disclosure practices immediately as being informed by the State Council. ${ }^{115}$ The General Administration of Quality Supervision, Inspection and Quarantine proposed launching an online platform for collecting and searching national standards. This proposal was accepted by the State Council, and the launch is now ongoing.

Imperfections in the Chinese review system, such as a non-independent judiciary, have led to concerns over the effective enforcement of FOI legislation. ${ }^{116}$ However, this does not mean that administrative reconsideration agencies and courts are incapable of causing government agencies to correct their non-compliance with proactive disclosure (see 9.3.1 and 9.3.2). The availability of internal and external review of government FOI decisions can have considerable influence of a cautionary nature. After all, no government agencies welcome being taken to court. ${ }^{117}$ FOI cases

112 Professor Hanhua Zhou, in an interview with Southern Weekend journalists, said that an administrative lawsuit or reconsideration might not be better than a report or complaint to remedy access requests. See Yongtong Su and Muzi Cai, 'Implementation of FOI Regulations Challenged at the Beginning' (in Chinese) Southern Weekend (Guangzhou) 10 July 2008, A05.

113 On 1 May 2008, Puzheng Han, a Hebei lawyer, reported several central government agencies' failure to disclose national standards to the State Council. He said that the General Administration of Quality Supervision, Inspection and Quarantine failed to proactively disclose the national standards of security requirements for students' stationery. He also mentioned that the Ministry of Health released its national standards for food safety and occupation health on its website, but it did not consider the online version as official. In addition, he found that the Ministry of Housing and Urban-Rural Development had sold national standards of urban development. See Yanxia Wu, 'A Cangzhou Lawyer Complained to Several State Agencies about the Failure to Disclose Information' (in Chinese) Yanzhao City Daily (Hebei) 6 May 2008, 5.

114 Shupeng Liu, 'The Suggestions of a Cangzhou Lawyer Attracted the Attention of the State Council' (in Chinese) Yanzhao City Daily (Shijiangzhuang) 5 August 2008, 5.

115 Ibid.

116 Jamie Horsley, China Adopts First Nationwide Open Government Information Regulations (2007) Freedom of Information Organisation <http://www.freedominfo.org/features/20070509.htm $>$ at 28 August 2007; Paul Hubbard, 'China's Regulations on Open Government Information: Challenges of Nationwide Policy Implementation' (2008) 1 Open Government: A Journal on Freedom of Information <http://www.opengovjournal.org/article/viewArticle/265> at 22 July 2009.

117 Interview with Government Officials (Interview in Person, 20 June 2008). 
are not the exception. Government officials in Shanghai state that a key reason for their better FOI performance compared with other regions is pressure from judicial review. ${ }^{118}$ Furthermore, the reporting mechanism is a useful tool for the demand side to remind government agencies of their duty to actively release. These review mechanisms have improved the capacity of the demand side to redress noncompliance with proactive disclosure.

\subsection{The demand side: willingness to redress non-compliance with proactive disclosure}

Apart from the capacity of active players on the demand side to prompt government agencies to correct their non-compliance with proactive disclosure requirements, rights activists, legal professionals and interested citizens are willing to compel government agencies to comply with proactive disclosure requirements through their access requests or complaints. This is because demand side players cannot bring government agencies which have not complied with proactive disclosure requirements to court directly. However, this indirect way has still helped enhance information flow from the government to society. The level of compliance with proactive disclosure thus has increased after the demand side input. Such input shows the dynamics of operation of FOI legislation in China.

The willingness of demand side players has come from increased rights consciousness over the last three decades (see 10.3.1). The building of the rule of law since the late 1970s has created many rights activists and legal professionals to take advantage of the FOI Regulations to ensure policy implementation and change (see 10.3.3). Demand side players either send their requests for information that is required to be proactively disclosed, or report non-compliance with proactive disclosure requirements, to supervisory agencies to redress government noncompliance with the requirements. Demand side players have also used enforcement mechanisms, including administrative reconsideration and lawsuits, to cause

118 Yangwu Ou and Yanbin Lv, 'FOI System and Legislation of FOI in China' (in Chinese) (2006) 6 Journal of Guangxi Administrative Cadre Institute of Politics and Law 14, 18. 
government agencies to reconsider refusals of information requests. Three factors explain the willingness of demand side players to increase government compliance with FOI legislation.

First, Chinese rights activists, such as Chen and Huang, have been a major force for rectifying non-compliance with proactive disclosure obligations, despite their requests often being viewed vexatious. In Guangdong, Shuwei Chen submitted approximately 109 applications for internal and judicial review of FOI decisions between 2002 and 2007. ${ }^{119}$ Chen's series of requests for information that is required to be proactively disclosed may have accelerated the adoption of the Shenzhen FOI Rules. ${ }^{120}$ Huang's 16 applications for FOI inventories also caused government agencies to rectify their non-compliance with proactive disclosure of such inventories. $^{121}$

Second, legal professionals have emerged as an important group to correct noncompliance with proactive disclosure requirements, through lawsuits, direct information requests and complaints. The request of Jianguo $\mathrm{Xu}$, a Beijing lawyer, for information that is required to be proactively disclosed won support from the court and the Hubei government. ${ }^{122}$ The report from Puzheng Han, a Hebei lawyer, to the State Council about state agencies' non-compliance with the proactive disclosure of national standards received a positive response from the State Council. This has benefited the proactive disclosure of national standards in China. ${ }^{123}$ Another case concerned the Sichuan earthquake. Jie Cheng, an associate professor in law, sent a request dated 13 June 2008 to the State Earthquake Administration for a seismic intensity distribution map. ${ }^{124}$ Cheng's request may have caused the State Earthquake Administration to publish the map. The State Earthquake Administration made this

119 Hongqing Dun and Doudou Ye, The Beginning of FOI Work (in Chinese) (2007) Caijing <http://www.caijing.com.cn/newcn/ruleoflaw/other/2007-04-30/18768.shtml> at 31 August 2007.

${ }_{120}$ See above $\mathrm{n} 102$ and the accompanying text.

121 See above $n 103$ and the accompanying text.

122 See above $\mathrm{n} 107$ and the accompanying text.

123 See above $n 113$ and the accompanying text.

124 Hujun Li, A Tisunghua Academic Requested Information on Seismic Intensity Distribution Map (in Chinese) (2008) Caijing <http://www.caijing.com.cn/2008-06-13/100069541.html> at 22 October 2008. 
map public on 29 August, abandoning its initial policy that required citizens to pay for this map. ${ }^{125}$

Third, ordinary citizens have acted as important driver to redress government compliance with proactive disclosure requirements for protecting their own interests. This is demonstrated by the Xu and other villagers ${ }^{126}$ and Zhou's requests ${ }^{127}$ for land use and house demolition, and Xie's request for documents concerning his pig farming business. ${ }^{128}$

\subsection{Conclusion}

This chapter argues that the significant strengthens for China in the implementation of FOI legislation have come from the dynamics of the supply and demand sides, in conjunction with proactive disclosure or push-emphasised legal design. On the supply side, there is a strong central political commitment and various transparency advocacy groups. This has prompted a comparatively high level of government compliance with proactive disclosure requirements.

On the demand side, rights activists, legal professionals and interested citizens have become major players in prompting government agencies to redress their noncompliance with proactive disclosure requirements. They are not only willing to force government agencies to implement the proactive disclosure duty, but capable due to support from internal and external review bodies. The input from demand side players has aided the level of FOI compliance.

However, the problem of the implementation of FOI legislation in China is government non-compliance with reactive disclosure of information that is not required to be proactively disclosed. This issue is explored in the next chapter.

\footnotetext{
125 The M8.0 Earthquake Intensity Distribution Map in Wenchuan (in Chinese) (2008) China Earthquake Administration <http://www.cea.gov.cn/manage/html/8a8587881632fa5c01 16674a01 8300cf/_content/0809/01/1220238314350.html> at 22 October 2008.

126 Wang, above $\mathrm{n} 104$.

127 See above $\mathrm{n} 110$ and the accompanying text.

128 See above $\mathrm{n} 111$ and the accompanying text.
} 


\section{0: NON-COMPLIANCE WITH REACTIVE DISCLOSURE REQUIREMENTS IN PRACTICE}

\subsection{Introduction}

This chapter explores the weaknesses in the implementation of FOI legislation in China. It argues that while significant steps to government compliance with proactive disclosure requirements can be ensured, it is difficult to anticipate that reactive disclosure will operate effectively in China at this early stage of implementation. The government has typically responded with a controlling flow approach to requests for information that is not required to be proactively disclosed. Chinese courts have bolstered this approach through various restrictions on FOI lawsuits, thus restricting the capacity of demand side players to request information from the supply side. Furthermore, demand side players' use of FOI legislation has been limited by legal, political and resource constraints. The problematic implementation of the access mechanism or reactive disclosure depicts a negative picture of FOI developments in China, which dampens optimistism about compliance with FOI legislation. However, a totally pessimistic view of FOI developments in China is also unwarranted, as Chapter 9 demonstrates.

This chapter has three sections. Section one explores government reluctance to answer access requests by adopting a controlling flow approach. Section two examines Chinese courts' conservative attitude toward FOI lawsuits, which constrains the capacity of demand side players to promote information flow. The third section examines various problems confronted by demand side players who use FOI legislation. 


\subsection{Low willingness from the supply side: a controlling flow approach}

Since the FOI Regulations came into force, the Chinese government/the supply side has taken a controlling flow approach to implement the access mechanism, reflecting low willingness to respond to access requests. Chinese scholars, like Cheng, also hold a similar view. 'Along with a limited capacity to comply with FOI legislation (see 9.1.2), this low willingness has prevented government agencies from fully complying with FOI legislation.

\subsubsection{Restricting the scope of FOI legislation to limit access}

Chinese government agencies have applied a controlling flow approach by restricting the scope of FOI legislation, with reference to both the bodies and the subject matter covered by the legislation.

\section{Limiting the coverage}

While no government agency is completely excluded from coverage of the FOI Regulations, some government agencies have deliberately limited this coverage. The General Office of the State Council has issued a policy document, titled 'Several Suggestions on Implementation of the China's FOI Regulations', ${ }^{2}$ to the effect that the General Office of the State Council will not process any access request directly. The General Office provides a negative precedent for other agencies to follow. The General Office of the Inner-Mongolia Autonomous Region prevents any access request, claiming that the Office has no information that needs to be accessed. ${ }^{3}$ This claim is unreasonable as a major responsibility of the General Office is drafting,

1 Cheng argues that government agencies have used the scope of government information, FOI exemptions and conflicts of law and regulations as grounds to refuse access requests. See Jie Cheng, 'Research on the Application of Law to Government Information Disclosure' (in Chinese) (2009) 3 Political Science and Law 28, 29.

2 Several Suggestions on the Implementation of FOI Regulations No 36 [2008] of the General Office of the State Council.

3 The General Office of the Inner-Mongolia Autonomous Region, The General Office's FOI Guide (in Chinese) (2008) <http://zfxxgk.nmg.gov.cn/default/modules/gkzn/znmx.jsp?columnid=iroot 19001 \&articleid $=15160>$ at 10 October 2008 . 
examining, verifying and circulating official documents, and so it should hold government information for public access.

\section{Limiting the scope of government information}

Setting limits on the scope of government information also reflects the Chinese government's controlling flow approach, as appears from the following six ways. First, government agencies have limited the scope of information by adopting their own FOI Rules. For example, the Commission of National Defence and Science Industry adopted FOI Interim Rules under which government information is defined as that it can be disclosed on its website. ${ }^{4}$ This definition is narrower than that under the FOI Regulations, and will likely impede the Commission's future compliance with the Regulations.

Second, government agencies have interpreted government information as excluding the information generated or obtained by them in the course of performing criminal enforcement or prosecution functions. It is argued that only the information generated or acquired by public security agencies under the Law on Administrative Penalties for Public Security 2005, not the Criminal Litigation Law 1996, falls within the subject matter of the FOI Regulations. ${ }^{5}$ Information regarding criminal litigation is not subject to the FOI Regulations, as the Lin case indicates. Lin lodged a request dated 28 February 2007 to Shanghai Municipal Public Security Bureau for a legal document, titled 'Rules for the Implementation of the Provisions on the Public Security Agency's Handling of Cases Involving the Crime of Injury' ${ }^{6}$ The Bureau replied that this document was used for criminal enforcement, rather than public

Freedom of Information Rules of the Commission of National Defence and Science Industry 2007 (China) Art 2.

5 Fangmin Ma, Explanations of Major Clauses in FOI Regulations (in Chinese) (2007) The Henan Government <http://www.henan.gov.cn/ztzl/system/2008/02/29/010059943.shtml> at $12 \mathrm{March}$ 2008; Jielin Wu, 'Issues Related to FOI Lawsuits' (in Chinese) (2009) 4 E-Government 39, 39.

6 The Shanghai Legislative Affairs Office and the Shanghai Institute for Administrative Law Studies, 'The Methods of Replying to Access Requests' (in Chinese) (2008) 16 The Brief Report on the Shanghai Government Rule of Law. 
administration, and so the document sought fell outside the definition of government information under the Shanghai FOI Rules. ${ }^{7}$

Third, government agencies have limited the scope of government information to information generated or obtained after the passage of the FOI Regulations. Youjian Huang and his colleagues applied for a survey report on the restructure of a water supply company, but their request was rejected. ${ }^{8}$ The government held that according to the principle of non-retroactivity, it was not required to disclose the information sought as it was generated before the effective date of the FOI Regulations. ${ }^{9}$ Other government agencies have learnt from this explanation, as demonstrated by the $\mathrm{Li}$ et al case. ${ }^{10}$ On 10 June 2008, Zihong Li and other villagers sent a request to a township government for information concerning the operation of a public coal company, but the government only replied in oral form. The requesters then filed a lawsuit in court. During the trial, the government's defence was that the information sought was created before the FOI Regulations took effect, so that the Regulations did not apply. The government has arguably misunderstood the non-retroactivity principle. It should be applied to the time when a request is submitted, not when the information is generated or obtained. ${ }^{11}$ However, some government officials deliberately persist with this misunderstanding. ${ }^{12}$ The reason for this is an unwritten rule that incumbent leaders are reluctant to handle unresolved issues left by their predecessors. ${ }^{13}$

Fourth, government agencies have interpreted the definition of government information in a literal way. The view is that government information must meet

Ibid.

Wenming Zhao, 'Reflecting on the First Lawsuit after FOI Regulations Took Effect' (in Chinese) Legal Daily (Beijing) 6 May 2008, 8; Bixin Jiang and Guangyu Li, 'Discussion of Issues Related to FOI Lawsuits' (in Chinese) (2009) 3 Political Science and Law 12, 18.

Ibid.

10 Yongqiang Xie, 'Villagers Filed Two Lawsuits against the Township Government' (in Chinese) Huashang Newspaper (China) 16 October 2008, A14.

11 Guangyu Li, 'Several Intangible Areas Related to FOI' (in Chinese) People's Court Daily (Beijing) 15 August 2008, 6.

12 Hua Liu, 'Several Legal Issues Related to FOI'(in Chinese) (2008) 6 Political Science and Law $66,70$.

13 Xuyang Sun, 'The First FOI Case Suspended in Binzhou' (in Chinese) The Beijing News (Beijing) 13 May 2008, A21. 
three conditions: generated or acquired by government agencies, aimed at exercising power and performing functions, and recorded in certain forms. ${ }^{14}$ These conditions derive from the literal meaning of government information. They have been used by government agencies to reject access requests for information that does not meet any of these conditions.

Also, government information that is not generated or acquired by government agencies is unlikely to be subject to disclosure because government agencies split hairs or quibble over small differences. For example, information compiled by government agencies does not need to be disclosed. Lian's request for some documents compiled by a police office was refused because the documents sought fell outside the category of government information generated or acquired by the police office. ${ }^{15}$

Moreover, government information unrelated to government responsibilities may not be subject to disclosure. Government agencies limit these responsibilities to economic and social management and public service, and thus any information requested should relate to this limitation. ${ }^{16} \mathrm{Gang} \mathrm{Li}$, the founder of the China Public Interest Litigation website, asked for information from the Shanghai government about tuition fees paid to the Shanghai National Accounting Institute for several senior figures' Executive Master of Business Administration training courses. ${ }^{17}$ The government replied that the information sought fell outside the category of government information, as it bore no relation to government responsibilities of economic and social management and public service.

14 Fuzhi Chen, 'Several Issues in Relation to FOI Regulations (Pt 1)' (in Chinese) (2007) 11 China Public Administration 21, 21.

15 Lian $v$ The General Team of Transportation Police (2005) 165 The Shanghai No 2 Intermediary People's Court (The Second Instance).

16 Xuan Zhang, Su Sued against the Personnel Management Bureau for Not Disclosing Government Information (in Chinese) (2005) Shanghai No 2 Intermediate People's Court <http://www.shezfy. com/spyj/alpx_view.aspx?id=2905> at 11 May 2008.

17 Gang $\mathrm{Li}$, The Legal Action against the Shanghai Government for Refusing to Disclose Information on Tuition Fees Paid for Civil Servants' Executive Master of Business Administration Training Courses (in Chinese) (2008) Public Interest Litigation <http://www.pil.org.cn/ article_view.asp?uid $=964>$ at 10 October 2008. 
Oral information that is not stored in any form is also excluded from disclosure. In the $S u$ case, the government replied to $\mathrm{Su}$ that it had no duty to disclose the information sought as it was communicated orally. ${ }^{18}$ The decision gives an incentive for government officials to communicate orally, rather than in writing, in the future.

Fifth, government agencies have archived some information immediately after receiving information requests in order to preclude disclosure. This is because the Archives Law 1987 sets a higher standard and a longer period for access to archived information, generally 30 years. ${ }^{19}$ This practice occurred in Shanghai. ${ }^{20}$ In order to solve this problem, the new Shanghai FOI Rules prescribe that government agencies, when transferring government information to state archives, must inform state archives whether or not the government information transferred falls within the scope of proactive disclosure, access or non-disclosure. ${ }^{21}$

Sixth, to frustrate requesters, government agencies have frequently argued that the information sought does not exist. While poor information management may contribute to this, government agencies may simply employ this justification to conceal less standardised practices. ${ }^{22}$ The revelation of these practices may embarrass government officials. Government agencies may also use this reply to conceal sensitive information, ${ }^{23}$ and so avoid negative social impact. More seriously, government agencies may use this excuse to conceal their wrongdoing.

\subsubsection{Using exemptions to control access}

The thesis finds that government agencies are using internal documents, a new nonstatutory exemption, and broad and vague exemptions laid down in the FOI Regulations to refuse access requests. The findings are supported by the following.

18 Su v Shanghai Huangpu District Personnel Bureau (2005) 72 The Shanghai No 2 Intermediary People's Court (The Second Instance).

19 The Archives Law 1987 (China) Art 19.

20 Jie Cheng, 'FOI Regulations and Public Libraries' (in Chinese) (2008) 4 Information and Documentation Services 16, 17.

Freedom of Information Rules 2004 (Shanghai) Art 35.

$22 \mathrm{Li}$, above $\mathrm{n} 11$.

23 Liu, above n 12, 69. 


\section{Internal documents: a non-statutory exemption}

Government agencies have adopted a non-statutory exemption - internal documents to exempt government information from access, despite this exemption not being envisaged by the FOI Regulations. Chinese law reformers have opposed writing the exemption of work secrets or internal documents into the Regulations. ${ }^{24}$ Its omission has reduced the non-disclosure degree of the Regulations, ${ }^{25}$ but in effect government officials have shown little respect for this omission. Internal documents generally include requests for instructions, research reports, leading officials' views and minutes. ${ }^{26}$ It is argued that these documents need to be urgently excluded from disclosure. ${ }^{27}$ The following three aspects explain the use of internal documents to refuse access requests.

First, requests for instructions have been claimed as internal documents that are not allowed to be disclosed. For example, Kang and other citizens asked for a letter to the Ministry of Labor for instructions concerning the methods used to count fired employees' total working years. ${ }^{28}$ Their request was refused as the government held that the letter fell into the category of internal affairs. ${ }^{29}$ A similar case occurred in Anhui. Yulai Yuan asked for a letter sent by the Anhui government for instructions about the laws and policies relating to the establishment of developmental zones and industrial parks. ${ }^{30}$ His request was refused by the government, which held that the information sought fell outside the category of government information under the FOI Regulations. Internal documents have been used as an effective tool for rejecting access to information concerning requests for instructions. This has limited the role of FOI legislation in improving information flow.

\footnotetext{
24 Mo Chen, 'Hanhua Zhou: 'The Key of FOI Regulations Is to Make FOI Become the Duty of the Government' (in Chinese) $21^{\text {st }}$ Century Business Herald (Beijing) 27 April 2007, 1.

25 Ibid.

26 Liu, above n 12.

27 Ibid.

28 Lin Jie and Xiangyang Sun, 'Twenty Six Guangzhou Citizens Took the Guangzhou Labor Bureau to Court' (in Chinese) China Youth Daily (Beijing) 7 January 2008, 7.

29 Ibid.

30 Xudong Qin, An FOI Lawsuit Was Tried with the Anhui Government Being Sued (in Chinese) (2008) Caijing <http://www.caijing.com.cn/2008-10-09/1 10018705.html> at 10 October 2008.
} 
Second, research reports have been considered as internal documents exempted from disclosure. The request for a survey report on the restructure of a water supply company was refused on the ground that it did not represent the government's opinion as the report only aided leaders to make decisions. ${ }^{31}$ Government officials have also held that leading officials' views fall into the category of internal affairs, and so are excluded from disclosure. ${ }^{32}$ Furthermore, requests for minutes have been generally refused by government agencies. ${ }^{33} \mathrm{~A}$ reason for this is that minutes record inconsistencies in government officials' arguments. ${ }^{34}$

Third, there is a tendency to regard information on the process of individual petitions as internal documents. In Shanghai, Zhang repeatedly petitioned against his layoff after $2002 .{ }^{35}$ In April 2002, a government agency and other departments jointly held a meeting about the process of Zhang's petition. Zhang's request for the minutes of this meeting in September 2007 was wrongly processed as a petition. The administrative reconsideration agency did not support his application as it held that the information sought was petition information. A similar case occurred after the FOI Regulations took effect. The General Administration of Quality Supervision, Inspection and Quarantine commissioned an expert team to investigate the quality of XGK-1400 rolling mills produced and sold by the Zhengzhou Top Company, and to produce a survey report. ${ }^{36}$ On 17 October 2008, Qi Wang was commissioned by businesses, experts and National People's Congress deputies to lodge a request for the survey report. However, the General Administration rejected the request, ruling

31 Zhao, above $\mathrm{n} 8$.

32 Lei Zhao and Yongtong $\mathrm{Su}$, 'Many Doubts about Government Information Disclosure' (in Chinese) Southern Weekend (Guangzhou) 8 May 2008, A04.

3 Ibid.

34 Interview with a Chinese Government Official (Interview in Person, 9 July 2008).

35 The Shanghai Legislative Affairs Office and the Shanghai Institute for Administrative Law Studies, 'Analysis of Discrimination between Access Requests and Petitions' (in Chinese) (2008) 5 The Brief Report on the Shanghai Government Rule of Law. See http://www.chinalaw.gov.cn/art icle/dfxx/dffzxx/sh/zffzjb/200807/20080700050059.shtml.

36 Xiaodong Zeng, The General Administration of Quality Supervision, Inspection and Quarantine Was Asked to Disclose the Investigation Report on the Quality of the Mills Produced by a Top Company in Zhengzhou (in Chinese) (2008) China Radio <http://www.cnr.cn/news/200810/t2008 1017_505126016.html> at 18 November 2008. The quality of the mills has been questioned by businesses and National People's Congress deputies in recent years. 
that the report was issued to respond to petitions for internal research. The rejection of access to information on the process of individual petitions has narrowed the scope of information set out in FOI legislation.

\section{A broad interpretation of exemption clauses}

The government has implemented a controlling flow approach through a broad interpretation of exemptions under the FOI Regulations in the following two ways. First, government agencies have broadened the exemptions under the FOI Regulations by adopting their own FOI Rules. Many government agencies, such as the Ministry of Education, ${ }^{37}$ the National Bureau of Tax, ${ }^{38}$ the State Archives Bureau, ${ }^{39}$ and the Shanghai government ${ }^{40}$ have added a deliberative process exemption to their FOI Rules. There is a tendency to exclude deliberative process information in all circumstances, even if the decision to which it refers has been made. Some authors hold that this information is not a concrete administrative action (see 5.2.3) with legal effect, and so is not subject to disclosure. ${ }^{41}$ The justification is primarily that the disclosure will not bring any public benefit, and thus its release is pointless. ${ }^{42}$ A deliberative process exemption, a key exemption in many FOI laws, is justified as it encourages free and frank discussion and avoids public confusion. ${ }^{43}$

However, the following exemptions are uncommon and difficult to accept. The Commission of National Defence and Science Industry introduced an exemption that prevents its agencies from disclosing information that might be sensitive or result in negative speculation. ${ }^{44}$ The Bureau of Intellectual Property's Interim Rules on FOI stipulated an exemption that allows its agencies not to disclose information that is

$37 \quad$ Freedom of Information Rules of the Ministry of Education 2008 (China) Art 14.

38 Freedom of Information Rules of the National Bureau of Tax 2008 (China) Art 13.

39 Freedom of Information Interim Rules of the Archives Bureau 2008 (China) Art 9.

40 Freedom of Information Rules 2004 (Shanghai) Art 10.

$41 \mathrm{Li}$, above $\mathrm{n} 11$.

42 Yong Yin and Yong Ding, 'On Legal Issues of FOI Lawsuits' (in Chinese) (2007)1Shanghai Journal of Law 40, 40.

43 Jordan v United States Dept of Justice, 591 F 2d 753, 772-3 (1978).

44 Interim Rules on Freedom of Information on the Government Website of the Commission of National Defence and Science Industry 2007 (China) Art 2. 
unsuitable for disclosure. ${ }^{45}$ These exemptions have narrowed the scope of information that can be potentially accessed under national FOI legislation.

Second, government agencies have broadly interpreted statutory exemptions to refuse access requests. This broad interpretation was already in place before the commencement of the FOI Regulations. The Ren case shows that government agencies intended to refuse access requests through the abuse of the exemption of state secrets. ${ }^{46}$ It is arguably unreasonable to wholly refuse an access request if only part of the information sought falls within the exemption category. Another case also reveals a broad interpretation of the exemption of state secrets. After a citizen learnt that the government wished to close some inferior companies and remove inferior products, he asked for a list of the closures and recalls. ${ }^{47}$ However, his request was refused because the information sought was marked as a confidential state secret, the lowest secrecy level laid down in the Law on the Protection of State Secrets 1988. It is difficult to accept that this information is a state secret.

The exemption of trade secrets has been used to include information on government procurement and other contracts to which the government is one of the parties. ${ }^{48} \mathrm{Hu}$ applied for an investment absorption agreement between a district government in Chongqing and a company. ${ }^{49}$ The government refused to disclose this agreement, classifying it as a trade secret. Other cases also reflect that government agencies have used the exemption of trade secrets to protect certain information. A public

45 Interim Rules on Freedom of Information of the Bureau of Intellectual Property 2008 (China) Art 7.

46 The city of Zhengzhou in Henan Province brought its FOI Rules into effect in 2005. In 2006, Ren requested the information on planning and licence arrangements for the installation of parkingmeter mechanisms. However, his request was refused for the reason that the information sought was marked as a confidential state secret. While the government admitted that the classification of parking planning as secret was unreasonable, they still held that some of the information sought concerning high-precision topographic maps fell into the category of state secrets. Donghong $\mathrm{Li}$ and Junde Li, 'Why Is There Glass Door Effect of Sunshine Government' (in Chinese) Henan Daily (Shijiazhuang) 22 June 2006, 12.

47 Yan Wu, "The "Glass Door" Effect Need to be Broken by FOI' (in Chinese) People's Daily (Beijing) 9 May 2008, 11.

48 Xudong Qin and Zhongxiaolu Chen, 'Slowly Move toward Sunshine Government' (in Chinese) (2008) 9 Caijing 132, 138.

49 Xiaomei Li and Wei Le, 'Judicial Review of FOI Lawsuits' (in Chinese) People's Court Daily (Beijing) 10 October 2008, 6. 
transportation company's financial reports were considered as trade secrets, and thus prevented from being disclosed. ${ }^{50}$ As a result, the requester was unable to judge whether or not the public transportation company's increase in bus fares was reasonable. Average social costs in relation to commercial residential houses were excluded from disclosure for being trade secrets. ${ }^{51}$ There is an apparent overuse of the trade secret exemption. This overuse has exempted much government information.

The privacy exemption has also been used to refuse a request for information that had been already disclosed. Li's request to the Xuchang government for a list of the beneficiaries of subsidies for breeding pigs was refused on the ground that the information sought fell into the privacy exemption category. ${ }^{52}$ This refusal did not adhere to the provincial government's policy document which requires government agencies to publish such a list.

\subsubsection{Imposing procedural restrictions on access requests}

Along with substantive restrictions placed on access requests, government agencies have also used procedural limits, such as requiring a purpose, setting hurdles for access, passing the buck and making perfunctory responses, to deny information access. The following substantiates these findings.

\section{Requiring purposes for access requests}

Several provincial governments, including Fujian Guizhou, Jiangsu and Zhejiang require applicants to specify their purpose for information requests. The State Council vests discretion in government agencies to refuse access requests that have no relation to requesters' special needs. ${ }^{53}$ It remains uncertain whether government agencies will rely on failure to specify a purpose as a ground for refusing a request.

\footnotetext{
50 Yanyan Lu and Lu Yang, Non-Compliance with FOI Regulations Found at the Sub-National Level' (in Chinese) Henan Business Daily (Shijiangzhuang) 12 June 2008, A10.

51 Wu, above $\mathrm{n} 47$.

52 A Citizen's Story about Access to Government Information (in Chinese) (2008) Jiangsu Informatisation <http://www.jsia.gov.cn/Browse/noinfocontent.aspx?id=1991\&tablename=tnoin fo $>$ at 10 October 2008 .

53 Several Suggestions on the Implementation of FOI Regulations, above 2.
} 
Apart from the purpose of an access request, some government agencies, like the Bureau of Foreign Currencies, also limit reuse of the government information disclosed. They require requesters to reuse the information disclosed for legal purposes. ${ }^{54}$ The purpose requirement, which does not appear in many other FOI laws, leaves open the prospect of refusing access requests, especially those for public information.

\section{Setting hurdles for access}

Government agencies have set unreasonable hurdles to block access requests. When Zhu sent a request to the Beijing Planning Committee, he was required to provide the file number of the document sought. ${ }^{55}$ Government agencies have also controlled access through limiting access methods. After Linxing $\mathrm{Xu}$ recognised that high voltage lines would go through his roof, he lodged an application to the Shanghai Municipal Environmental Protection Bureau for information concerning an environmental impact assessment report on this project. ${ }^{56}$ The Bureau accepted Xu's request, but informed him that he was not permitted to photocopy the report, and only read it on the spot. The curb on access methods has limited the capacity of the demand side to use, distribute and analyse government information.

\section{Passing the buck}

Government agencies have used the strategy of passing the buck to postpone a reply to a request. A journalist submitted a request to the Linyi County Land Resources Bureau for information on the process of examining and approving a company's application for land use. ${ }^{57}$ The Bureau replied that it did not hold that information, and suggested that its Xingtong Branch might hold the information, but this Branch

Working Procedures for Access to Government Information of the Bureau of Foreign Currencies 2008 (China) Art 14.

55 Zongzhi He, 'FOI Still Has a Long Way to Go' (in Chinese) $21^{\text {st }}$ Century Business Herald (Guangzhou) 8 July 2008, 8.

56 Junxiu Wang, 'A Lawyer Discussed Various Strange Phenomena regarding FOI' (in Chinese) China Youth Daily (Beijing) 10 May 2008, 3.

57 Non-Disclosure Problems for Several Local Governments (in Chinese) (2008) Xinhua Net $<$ http://news.xinhuanet.com/politics/2008-07/30/content_8851290.htm> at 10 March 2009. 
referred him to the Hengyuan Branch because the company was under the jurisdiction of that Branch. When the journalist went to the Hengyuan Branch, he was told that this company was directly managed by the Land Resources Bureau that operated one of the county's investment absorption projects, and thus passed its responsibility back to the Bureau. As a result, the journalist did not obtain the information requested. This strategy is used to test requesters' patience, and operated as de facto blocks to accessing information.

\section{Making perfunctory responses}

Government agencies have made perfunctory responses to access requests, rarely working closely with requesters to accommodate their needs. Realising that high voltage lines would go through the roof of his house, Wenhua Ni went to the Shanghai Municipal Planning Bureau to request drawings in relation to the construction of Yuanyun $220 \mathrm{kV}$ transformer station. ${ }^{58}$ The Bureau replied to $\mathrm{Ni}$, and gave him about seven drawings, but $\mathrm{Ni}$ could not understand the drawings and identify the sign of high voltage lines. This reply meant nothing to him. It did not add helpful context to raw data, and so caused unnecessary disputes between $\mathrm{Ni}$ and the government. Such perfunctory treatment reflects the dominant notion, which holds that FOI legislation only allows government agencies to provide raw information without editing or explanation. ${ }^{59}$ Government agencies may apply this notion mechanically to reply to FOI requests.

\subsection{Review systems: limiting the capacity of the demand side to request government information}

The current internal and external review systems have constrained the capacity of demand side players to promote greater information flow because they have bolstered the government's controlling flow approach toward information requests. As appears from what follows, administrative reconsideration has been inappropriately used by

\footnotetext{
$58 \quad$ Wang, above $\mathrm{n} 56$.

59 The Shanghai Science and Technology Commission, Freedom of Information Rules 2004 Annual Report 2005; Wu, above n 5, 40.
} 
administrative reconsideration agencies to both implicitly and explicitly uphold original decisions. In general, Chinese courts have shown a conservative attitude toward FOI lawsuits, upholding most FOI decisions made by government agencies via various procedural and substantive constraints.

\subsubsection{Administrative reconsideration}

Administrative reconsideration, a category of internal review, is provided under the FOI Regulations to examine FOI refusals. ${ }^{60}$ However, this type of internal review has bolstered the controlling flow approach to access requests in the following three ways. First, administrative reconsideration agencies have upheld most original decisions. According to Snell, one piece of administrative adversarialism non-compliance is that internal review upholds more than 75 percent of original decisions. ${ }^{61}$ This was the case in Shanghai. Within the last four years, the Shanghai Legislative Affairs Office, the administrative reconsideration agency, upheld approximately 80 percent denials of access. ${ }^{62}$

Second, administrative reconsideration agencies have used mute administrative reconsideration to object to information disclosure. Chen submitted his request to the Guangdong Province Land and Resources Bureau for information concerning a project to create farmland, but the Bureau replied that the information requested was not subject to disclosure. ${ }^{63}$ Chen applied for administrative reconsideration to the Ministry of Land and Resources, but received no response.

Third, administrative reconsideration agencies have asserted that FOI refusals fall outside the scope of administrative reconsideration. Gao requested the minutes of a mediation meeting, but the township government provided him with inaccurate

$60 \quad$ Freedom of Information Regulations 2007 (China) Art 33.

61 Rick Snell, 'Administrative Compliance - Evaluating the Effectiveness of Freedom of Information' (2001) 93 Freedom of Information Review 26, 28.

62 The Shanghai Government, Freedom of Information Rules 2004 Annual Report 2008.

63 Hongqing Dun and Doudou Ye, The Beginning of FOI Work (in Chinese) (2007) Caijing <http://www.caijing.com.cn/newcn/ruleoflaw/other/2007-04-30/18768.shtml> at 31 August 2007. 
minutes. ${ }^{64}$ Gao asked for administrative reconsideration, but the reconsideration agency stated that his request did not fall within the scope of administrative reconsideration, even the Ningbo FOI Rules empowered requesters to apply for administrative reconsideration. This argument lacks rigour now that the FOI Regulations are in effect. The Regulations, which are of higher legal status than the FOI Rules, establish a stronger legal basis for the exercise of administrative reconsideration.

\subsubsection{Administrative lawsuits}

During the first six months' implementation of the FOI Regulations (1 May 2008-31 October 2008), courts processed a series of lawsuits. The results reveal that Chinese courts tend to adopt a conservative attitude toward the process of access to information that falls outside proactively disclosed categories. This attitude may assist the Chinese government to strengthen its controlling flow approach, thus limiting the capacity of demand side players to apply for government information. This conservative attitude may have resulted in concerns over Chinese courts' weak position in rectifying government non-compliance with access requests. ${ }^{65}$

\section{The scope of administrative lawsuits}

Courts may reject an FOI lawsuit on the ground that it does not fall within the scope of administrative lawsuits, as appears from the following. First, courts have interpreted a reviewable administrative action strictly. Chinese courts are sceptical about whether the access right is actionable, as common understanding holds that a citizen can only sue for an infringement of personal or property rights pursuant to the

64 Gao v Ninghai County People's Government (2006) 3 The People's Court of Fenghua City (The First Instance).

65 Jamie Horsley, China Adopts First Nationwide Open Government Information Regulations (2007) Freedom of Information Organisation <http://www.freedominfo.org/features/20070509.htm> at 28 August 2007; Paul Hubbard, 'China's Regulations on Open Government Information: Challenges of Nationwide Policy Implementation' (2008) 1 Open Government: A Journal on Freedom of Information <http://www.opengovjournal.org/article/viewArticle/265> at 22 July 2009. 
Administrative Litigation Law $1989 .{ }^{66}$ The infringement of an access right, which is irrelevant to any infringement of personal or property rights, is thus considered not to belong to the category of cases that courts must accept. ${ }^{67}$ Furthermore, it has been recognised that political rights, such as the access right, are excluded from the scope of a lawsuit. ${ }^{68}$ An exception is Shanghai as noted below.

Yet, the doubt about whether the access right is actionable should not persist, as the FOI Regulations permit citizens to bring an FOI lawsuit to court. ${ }^{69}$ This stipulation does not conflict with the Administrative Litigation Law 1989, which vests power in courts to accept an administrative lawsuit that may be brought pursuant to the provisions of relevant regulations. ${ }^{70}$

While courts in Shanghai accepted lawsuits concerning the access right after its FOI Rules took effect in 2004, courts in other cities, the Zhengzhou City, for example, refused to accept these lawsuits, as the Ren case indicates. Ren sought judicial review of the government refusal of his request for information on planning and licence arrangements for installation of parking-meter mechanisms. ${ }^{71}$ The court ruled that although Ren had a right to access the information, he could not prove that the FOI reply infringed upon his lawful rights and interests, which was one condition for the plaintiff bringing a lawsuit to court. ${ }^{72}$ As a result, the court rejected Ren's action.

Even after implementation of the FOI Regulations, some courts hold this narrow explanation and reject FOI lawsuits. Chen submitted his application to the Beijing

66 Guangyu Li, 'Parties to FOI Lawsuits' (2009) 4 E-Government 43, 44; Guangyu Li, 'Several Issues concerning the Acceptance of FOI Lawsuits (Pt 1)' (in Chinese) People's Court Daily (Beijing) 31 May 2007, 6.

67 Ibid.

68 Yin and Ding, above $\mathrm{n} 42,41$.

69 Freedom of Information Regulations 2007 (China) Art 33.

The Administrative Litigation Law 1989 (China) Art 11.

$\mathrm{Li}$ and $\mathrm{Li}$, above $\mathrm{n} 46$.

72 The Administrative Litigation Law 1989 (China) Art 41. This Article stipulates that the following conditions shall be met when a suit is brought: the plaintiff must be a citizen, a legal person or any other organisation that considers a concrete administrative action to have infringed upon his or its lawful rights and interests; there must be a specific defendant or defendants; there must be a specific claim and a corresponding factual basis for the suit; and the suit must fall within the scope of cases acceptable to the court and the specific jurisdiction of the court where it is filed. 
Municipal Public Security Bureau for information concerning the use of management service fees for raising dogs. ${ }^{73}$ After the Bureau rejected his request, Chen took legal action against this refusal. However, the court rejected this action as the defendant was not required to reply to the requester. ${ }^{74} \mathrm{Gao}$ 's request to a township government for information on an inappropriate transfer of resettled houses was refused. ${ }^{75} \mathrm{He}$ then sued the government for non-disclosure of related information, but the court ruled that his lawsuit did not fall under the Administrative Litigation Law 1989, and so rejected it.

Second, courts have conservatively interpreted a concrete administrative action, an administrative activity that aims at specified events or individuals and can only be carried out once (see 5.2.3). They hold that an FOI refusal has no real impact on the complainant's right and duty, and so it falls outside the scope of administrative cases. ${ }^{76}$ This is because the Supreme Court excludes review of the exercise of a concrete administrative action that has no real impact on a citizen's right or duty. ${ }^{77}$ This impedes courts' ability to accept an FOI lawsuit because they hold that an FOI refusal, which is a concrete administrative action, does not infringe on a requester's right, or impose a duty. ${ }^{78}$ Jinsong Hao lodged a request to the Shaanxi Forestry Department for information on an investigation concerning the disclosure of controversial pictures of a rare wild South China tiger. ${ }^{79}$ The Department replied that it would disclose the information after the investigation was completed. ${ }^{80}$ Hao was dissatisfied with this reply, and took legal action against the Department, which the

73 Xudong Qin and Zhongxiaolu Chen, Citizens Applied for Government Information to Promote 'Sunshine Government' (in Chinese) (2008) Caijing <http://www.caijing.com.cn/20080504/59254. shtml> at 17 May 2008.

74 Yuhua Chen v The Beijing Municipal Public Security Bureau (2008) 155 The Dongcheng District People's Court of Beijing (The First Instance).

75 Liying Gao $v$ The Beijing Sijiqing Township Government (2008) 201 The Haidian District People's Court of Beijing (The First Instance).

76 Jiang and $\mathrm{Li}$, above $\mathrm{n}, 12 ; \mathrm{Li}$, above $\mathrm{n} 11$.

77 The Supreme Court's Explanation on Several Questions Related to the Implementation of the Administrative Litigation Law 1989 (China) Art 1.

$78 \mathrm{Li}$, above $\mathrm{n} 11$.

79 Jun Ma et al, 'FOI Regulations Came into Force on 1 May: Obtaining a Real Picture of FOI' (in Chinese) Youth Weekend (Beijing) 15 May 2008, A08.

80 Jinsong Hao v The Shaanxi Forestry Department (2008) 1 The Lianhu District People's Court of Xi'an. 
court rejected as it held that the FOI reply did not have any real impact on his rights and duties. $^{81}$

Third, courts have rejected an FOI legal action on the basis that information sought falls outside the scope of administrative lawsuits. The Youjian Huang and other colleagues' request was refused by the government. ${ }^{82}$ The court did not accept the subsequent lawsuit on the ground that the information sought related to an enterprise's restructure, and not fall within the scope of administrative lawsuits. ${ }^{83}$ In this case, the court did not reject the case from the quality of being actionable, but rejected it from the category of the information sought, an enterprise's restructure, which is not reviewable. The major concern is that courts may exploit this explanation to reject contentious cases in the future.

\section{A wrong jurisdiction}

Courts have rejected an FOI lawsuit on the ground that it falls outside its jurisdiction. This reason may be used by a court to pass the responsibility to another court. Zhu submitted a request to the National Audit Office for information concerning the inappropriate use of land-use fees and the like. ${ }^{84}$ His request was refused based on the exemption for social stability. Zhu's lawsuit in the Beijing No 1 Intermediate Court was rejected on the ground that the General Office of the National Audit Office, not the National Audit Office, was the correct defendant, and the former fell under the jurisdiction of the Xicheng District Court. Zhu insisted on taking the National Audit Office, rather than its General Office, to court as he recognised that only the former

\section{Ibid.}

Zhao, above $\mathrm{n} 8$.

83 Weijian Wang and Jiming Yu, 'Are Government Agencies Getting Used to FOI?' (in Chinese) People's Daily (Beijing) 8 May 2008, 10. The Supreme Court circulated Several Issues Related to the Trial of Civil Dispute Cases Related to Restructuring of Enterprises Provisions in 2003. Article 3 stipulates that courts shall not accept civil actions regarding disputes occurring in the course of administrative adjustment or transfer of an enterprise's state-owned assets by a competent government department. This Article became the basis for the court rejecting the FOI lawsuit lodged by Huang and others.

84 Shijue Lin, "FOI Requests Encounter "Difficulties at the Beginning", Similar to "Action Art" (in Chinese) Procuratorial Daily 23 July 2008, 5. 
was the qualified defendant in accordance with the law. ${ }^{85}$ The Intermediate Court received Zhu's files this time, but did not inform Zhu whether his lawsuit was accepted or rejected. ${ }^{86}$

\section{Postponing the acceptance}

Courts have postponed a time limit to decide whether to accept or reject an FOI lawsuit, as the $L i$ case shows. ${ }^{87} \mathrm{Li}$ sent a request dated 16 September 2005 to the Shanghai Municipal Engineering Management Bureau for information on the roads built by loans or public funds. He received no reply from the Bureau within the set timeframe, and then sought judicial review of the decision on 19 October 2005. The court refused his claim on the ground that it only accepted a lawsuit until a government agency did not reply to a requester over 60 days. ${ }^{88}$ Thus, the court held that $\mathrm{Li}$ should file after 16 November 2005. It interpreted narrowly the Supreme Court's Explanation on Several Questions Related to the Implementation of the Administrative Litigation Law 1989. This document also allows the court to accept a lawsuit in relation to a government agency that does not perform its statutory duty within the set timeframe under rules, like the Shanghai FOI Rules. The Rules require government agencies to provide information within 30-day maximum after receiving access requests. As $\mathrm{Li}$ had lodged his lawsuit after more than 30 days of his request was sent, it appears that the court could have accepted Li's lawsuit, but opted not to do so. The court may have utilised the general timeline, 60 days, to give itself more time to consider the acceptance of a contentious case.

85 Article 20 of the Supreme Court's Explanation on Several Questions Related to Implementation of the Administrative Litigation Law 1989 only allows the government agency, rather than its instrumentalities to be the defending party, even if its instrumentalities make a concrete administrative action.

86 Lin, above $n 84$.

87 Public Interest Litigation, Inappropriateness of the Rejection of an FOI Lawsuit by the Shanghai Luwan District Court (in Chinese) (2005) <http://www.pil.org.cn/article_view.asp?uid=175>at 5 September 2007.

88 The Supreme Court allows courts to accept a lawsuit regarding a government agency which does not perform its statutory duty within 60 days. The Supreme Court's Explanation on Several Questions Related to the Implementation of the Administrative Litigation Law 1989 (China) Art 39. 
Unfortunately, courts have kept silent on some contentious FOI refusals. This was the case for the first FOI lawsuit after the FOI Regulations came into effect in China. The preceding Youjian Huang and other colleagues' information request may have revealed an illegal closing of the water supply company. ${ }^{89}$ Their request was refused by the government on the ground that the information requested fell outside the scope of information required to be disclosed. Hence, Huang and his colleagues filed a lawsuit to the Binzhou Intermediary Court, but the Court did not inform them as to whether it would accept or reject this complaint within seven days, the time limit set out in the Administrative Litigation Law 1989. ${ }^{90}$ The court explained that it could not inform, as the case was a waiting instruction from the Supreme Court. ${ }^{91}$ The reason for this delayed response is the court's reluctance to be the first to try a contentious case. One judge confessed that the acceptance of such a contentious case needed professional knowledge as well as courage. ${ }^{92}$

\section{Literally explaining the definition of government information}

Courts have interpreted the definition of government information in a literal way, as appears from the following. First, they have asserted that information compiled, rather than generated or acquired by a government agency is not subject to disclosure. This assertion was found in the Lian case. ${ }^{93}$ The court rejected Lian's claim on the ground that the documents requested were compiled by the defendant to facilitate its

89 Zhao, above $\mathrm{n} 8$.

90 Article 42 of the Administrative Litigation Law stipulates that when a court receives a bill of complaint, it shall, upon examination, file a case within seven days or decide to reject the complaint.

91 Zhao, above $\mathbf{n} 8$.

92 Lin, above $\mathrm{n} 84$.

93 In 2004, Lian submitted his request to the General Team of Transportation Police of the Shanghai Municipal Public Security Bureau (Transportation Police) for the following two documents: 1. suggestions about the trial on compensation arising from injuries; 2 . references concerning compensation occurring traffic accidents. The Transportation Police replied that it did not hold the information requested. Lian brought a lawsuit to the Shanghai Huangpu District Court. The Court rejected Lian's claim as it held that the information sought fell outside the scope of information that is defined under the Shanghai FOI Rules. Lian then filed a lawsuit to the Shanghai No 2 Intermediate Court. The Court upheld the judgment made by the Shanghai Huangpu District. It considered that the defendant had no duty to disclose such information as the information generated by the defendant was a category of internal working materials which did not fall within the scope of the information defined under the Shanghai FOI Rules. See The Lian case, above $\mathrm{n}$ 15. 
daily work, and thus fell outside the scope of information defined under the Shanghai FOI Rules. The case reveals that compiled government information falls outside the scope of information subject to disclosure. While this case was processed before the FOI Regulations took effect, it may set a precedent for similar cases in the future.

Second, courts have maintained that oral information is excluded from disclosure. The $S u$ case indicates that courts support the claim that information communicated in an oral form is not subject to disclosure. ${ }^{94}$ Third, courts have held that information irrelevant to the exercise of government responsibilities is excluded from disclosure. In the $S u$ case, the court adjudged that the information sought was related to the reform of salaries, which had no relation to economic, social management, or public service, and so was in the category of internal affairs that was not required to be disclosed. ${ }^{95}$

\section{Examining purposes for access requests}

Courts have used the purpose requirement under the FOI Regulations (see 8.3.2) to reject FOI legal actions, especially contentious ones. The rationale is that the requester's purpose must be examined to control the abusive use of access rights. ${ }^{96}$ Observers predict that the request for information on environmental pollution would be likely to be rejected by the court on the ground that it is irrelevant to requesters' special needs. ${ }^{97}$ Yulai Yuan filed a lawsuit to the Hefei Intermediary Court after his request for a letter sent by the Anhui government for instructions about laws and

94 In 2004, Su submitted his request to the Shanghai Huangpu District Personnel Bureau for the notice concerning the reform of salaries issued by this Bureau, the Shanghai Personnel Bureau's explanation for this reform, and the Shanghai Municipal Staff Quota Office's notice on this reform. The Bureau replied that it had no duty to disclose the last two pieces of information as they fell outside the scope of the information defined under the Shanghai FOI Rules. Su applied for external review by the Shanghai Huangpu District Court. The Court considered that the information requested was communicated orally, and thus did not meet the definition of government information under the Shanghai FOI Rules. As a result, the Shanghai Huangpu District Court rejected Su's claim. The Shanghai No 2 Intermediary Court upheld the judgment made by the Shanghai Huangpu District Court. See The $S u$ case, above $\mathrm{n} 18$.

95 Ibid.

96 Yong Yin, 'New Thoughts on Trying FOI Cases' (in Chinese) (2007) 5 Shanghai Journal of Law 51,52 .

97 Qin and Chen, above n 48. 
policies was refused. ${ }^{98}$ The court rejected this application on the basis that the information sought lacked relation to the requester's special needs.

\section{No legal interest in the information sought}

Courts have rejected an administrative lawsuit on the ground that the requester has no legal interest in the information sought. This rejection may have misunderstood the requirement under the Supreme Court's explanation, which states that only individuals who have legal interest with administrative actions are entitled to file an administrative lawsuit. ${ }^{99}$ This sets a limit on the qualification of a plaintiff. However, the legal interest limit should be understood between the requester and the request, rather than the requester and the information sought. ${ }^{100}$ Arguably, any government information is of interest to citizens from either a broad or narrow standard. However, the legal interest limit presents an opportunity for courts to support a narrow standard, in particular when they process contentious cases.

\section{Unreasonable burden of proof}

Courts have used the ambiguity of burden of proof to dismiss FOI legal actions, especially when reviewing FOI decisions in which officials claim that the information sought does not exist. Such claims create difficulties for courts, which must decide whether plaintiffs or defendants bear the burden of proof, and to what degree. ${ }^{101}$ While the government/defendant bears the burden for its concrete administrative action, ${ }^{102}$ this requirement contradicts a fundamental principle of the standard of proof; it is not a party's duty to provide evidence to support his allegation about the fact does not exist. ${ }^{103}$ This contradiction raises the possibility for courts to

Qin, above $\mathrm{n} 30$.

The Supreme Court's Explanation on Several Questions Related to Implementation of the Administrative Litigation Law 1989 (China) Art 12.

$100 \mathrm{Li}$, above $\mathrm{n} 11$.

101 Lin, above $n 84$.

102 The Administrative Litigation Law 1989 (China) Art 32.

103 Yin and Ding, above n 42, 43; Wu, above $n$ 5, 40. 
frustrate the requester or plaintiff, specifically when trying some contentious cases, as the Dong case indicates. ${ }^{104}$

\subsection{The demand side: diverse interests in the use of FOI legislation}

There is concern about a low use of China's FOI Regulations. ${ }^{105}$ It is difficult to obtain an accurate picture of the use of FOI legislation at present because official statistics about the types of FOI requesters are not available. However, secondary data gathered from a wide range of sources for this research shows that the public expressed interest in access to government information for varied purposes during the first six months after the FOI Regulations came into effect (1 May 2008-31 October 2008). This could lessen the concern about low use. However, the role of demand side players, especially journalists and lawyers, is constrained due to the government's controlling flow approach to FOI requests (see 10.1). Furthermore, diverse interests in the use of FOI legislation by demand side players have resulted in patchy, if not completely poor, FOI performance in terms of responses to requests.

\subsubsection{Chinese citizens: using FOI for various purposes}

Even in liberal democratic states, FOI scholars are concerned about citizens' low incentives to request government-held information, especially public information. ${ }^{106}$ The state's relation to the citizen in China magnifies this concern due to its concept

104 The first challenge to an FOI decision in Shanghai occurred only 10 days after the city brought its FOI Rules into effect. On 10 May 2004, Dong submitted a request to the Shanghai Xuhui District Real Estate Bureau for registration information concerning her father's purchase of a house and the government's takeover of the house from 1 September 1947 to 16 July 1968 . After the Real Estate Bureau refused to disclose the information, Dong brought an appeal to the Shanghai No 1 Intermediate Court, but the Court considered that there was no longer a need to decide whether it should be disclosed or not as the Real Estate Bureau argued that the information sought did not exist, and so it rejected Dong's appeal. See Daoquan Li and Xuqiang Wang, 'A Shanghaiese Lodged the First FOI Lawsuit' (in Chinese) Oriental Morning Post (Shanghai) 14 June 2004, A1; 'A 70-Year-Old Woman Lost Her Case Which Was the First FOI Case That Was Closed without Ending' (in Chinese) Oriental Outlook (Beijing) 19 August 2005.

105 Shixi Liu and Chao Wang, 'Citizens Challenge the Government through FOI Regulations' (in Chinese) China Youth Daily (Beijing) 6 May 2008, 7; Hanhua Zhou, Speech delivered at Seminar on the FOI Regulations, Beijing, 17 March 2007. See http://www.hongfan.org.cn/file/upload/2007 103/17/1215097825.pdf.

106 Alasdair Roberts, Blacked out: Government Secrecy in the Information Age (1 ${ }^{\text {st }}$ ed, 2006) 116-7. 
of citizenship as a tool for asserting rights against the state. ${ }^{107} \mathrm{~A}$ valid concern must be viewed against the backdrop of the changing situation in China. Indeed Chinese citizens have increased their rights consciousness, which may have resulted in access to information that involves immediate interests.

\section{Chinese citizens: increasing rights consciousness}

Chinese citizens' rising rights consciousness, which has been stimulated by the reform and opening up policy that commenced in the late 1970s, may benefit the use of FOI legislation. ${ }^{108}$ Before that, citizens' individual rights were largely neglected due to greater emphasis on national and collective interests. ${ }^{109}$ The amendment of the Constitution in 2004 responded to this trend, requiring the state to respect and preserve human rights. ${ }^{110}$ The following five aspects explain Chinese citizens' growing awareness of rights.

First, rights consciousness, property rights consciousness in particular, has increased. This prompted the amendment to the Constitution in March 2004, which announces that 'the state protects the right of citizens to own lawfully earned income, savings, houses and other lawful property'. ${ }^{111}$ This also resulted in the adoption of the Property Law in 2007, which confers on private property the same protection as state-owned assets. ${ }^{112}$

Second, Chinese citizens have an enhanced consciousness of personal freedom. The death of Zhigang Sun prompted three law postgraduates to jointly petition the Standing Committee of the National People's Congress to revoke the State Council's detention rules due to their unconstitutionality. ${ }^{113}$ The State Council was pressured by

107 Colin Darch and Peter Underwood, Freedom of Information and the Developing World: The Citizen, the State and Models of Openness ( $1^{\text {st }}$ ed, 2009) 173.

108 Feiyu Liu and Conghu Wang, Evaluating FOI from Different Perspectives (in Chinese) $\left(1^{\text {st }}\right.$ ed, 2005) 15.

109 Ibid.

110 The Constitution 1982 (China) Art 33.

111 The Constitution 1982 (China) Art 13.

112 The Property Law 2007 (China) Art 4.

113 Longyun Niu, 'Scrutinisation of the Constitutional Review System following the Sun Incident' (in Chinese) (2003) 22 Outlook Weekly 50, 50-1. Zhigang Sun was treated as a vagrant and detained 
this, replacing detention rules in June 2003 by new rules that change migrant detention centres into voluntary service ones. ${ }^{114}$

Third, Chinese citizens have armed themselves with the Constitution to reduce employment and gender discrimination. Many have called for a review of discriminatory employment against Hepatitis B virus carriers in recent years. ${ }^{15}$ This may have prompted the central government to adopt a new policy document in 2005 in order to resolve this discriminatory issue. ${ }^{116}$ Gender discrimination has also caught public attention, with a special focus on different retirement age for males and females. ${ }^{117}$ Chinese citizens have challenged this discriminatory requirement by referring to Article 48 of the Constitution, which entitles males and females to equal employment rights. ${ }^{18}$

Fourth, Chinese citizens have sought judicial review of administrative decisions to protect their own legal rights and interests. There were only 13,006 administrative lawsuits in 1990, the first year of operation of the Administrative Litigation Law 1989, but 52,792 in $2006 .{ }^{119}$ Fifth, Chinese citizens have strived for election as deputies of congresses by self-nomination to protect their interests more directly. A few citizens won election for deputies through self-nomination. ${ }^{120}$

in a repatriation centre in Guangzhou in March 2003. He was beaten to death by inmates a few days later.

114 Measures for the Administration of Relief for Vagrants and Beggars without Assured Living Sources in Cities 2003 (China).

1 is Xianzhu Zhang first sued a personnel bureau for its refusal of recruiting him due to his positive Hepatitis B virus status. In 2004, many Chinese citizens petitioned the Standing Committee of the National People's Congress to review discriminatory employment against Hepatitis B virus carriers. See Voices against Discrimination: An Update of Recent Cases and Developments (2006) China Law and Governance Review <http://www.chinareview.info/pages/case.htm> at 24 April 2008.

116 General Standards on Physical Examinations concerning the Employment of Civil Servants (for Trial) 2005 (China) Art 7.

117 In China, a general retirement age for females is 55 , but 60 for males.

118 Xianghua Zhou sued against the unconstitutionality of retirement age requirements in 2005 in China for the first time, but she lost her action. See Zhonghai Niu, 'The Latest Developments in the Case regarding Different Retirement Age for Males and Females in Pingdingshan: Review of the Constitution Recommended' (in Chinese) Dahe Daily (Zhengzhou) 24 July 2006, A09.

119 Yong Xia et al, The Development Report of Rule of Law in China (in Chinese) $\left(1^{\text {st }} \mathrm{ed}, 2006\right) 72$.

120 In 1998, Lifa Yao became the forerunner who was elected as a deputy of the fourth people's congress of Qianjiang City by a method of self-nomination. In 2003, Lian Wang won a deputy 


\section{Chinese citizens: primarily for information that involves their immediate interests}

Interviews conducted as fact of this thesis reveal that Chinese citizens have a strong interest in accessing information that involves their immediate interests. Yet, it is difficult to see a continuing motivation to use FOI legislation because the FOI Regulations have only devised a limited access mechanism that cannot become a realistic tool for solving their issues.

During the first six months of implementation of the FOI Regulations, Chinese citizens used FOI legislation for access to the following five main categories of government information, all closely related to their immediate interests. First, they applied for information to examine whether or not their interests had been violated. This occurred primarily in three areas: enterprise restructure, house demolition and land use. Given China's rapid marketisation and urbanisation in the last three decades, this is hardly surprising. Second, Chinese citizens used the FOI Regulations to better understand their personal legal matters, such as pending criminal and civil cases. Third, they filed access requests to learn more about how government agencies processed their business affairs. Fourth, they asked for historical records to solve their outstanding issues with the government, such as housing takeovers before and during the Cultural Revolution. FOI legislation provided an indirect opportunity for individuals aggrieved by the enforced takeovers to seek protection for their private property. Fifth, Chinese citizens requested information on their personnel files in order to claim benefits from the government (Appendix 8).

However, the preceding discussion of citizens' positive use of FOI legislation does not necessarily indicate an optimistic view. It is likely that Chinese citizens will not have steady impetus to use FOI legislation, especially when they find that the use cannot aid them to solve their issues. At the present stage of implementation, there are three problems concerning citizens' use of FOI legislation. First, there exists

election in Futian District of Shenzhen City as an independent candidate. In the same year, Zhiyong $\mathrm{Xu}$ and Hailian Lie also secured their self-nomination and won their deputy election in their own election districts in Beijing. 
doubt about the effectiveness of the access mechanism. In interviews, many citizens said that FOI requests did not assist in solving their problems. ${ }^{121}$ Some citizens displayed reluctance to request government information, fearing that they would be unable to obtain the information they wanted. ${ }^{122}$ Academics said that if he needed government information, his first course was to make full use of close relationships with government agencies, rather than sending direct access requests. ${ }^{123}$ Second, FOI officials complained that citizens did not really need government information, but instead official responses to their outstanding problems that could not be easily provided. ${ }^{124}$ This may lessen FOI officials' motivation for processing information requests.

Third, petitioners heavily used the access mechanism for information on various outstanding issues with the government, ${ }^{125}$ but the outcome of this use was generally negative. The access mechanism is becoming another petition mechanism. ${ }^{126}$ Petitioners expected that access to information regarding the process of their administrative disputes would enable the disputes to be reconsidered by government or retried in court. While petitioners have showed their special interest in access to information, they will likely lose their interest in this vehicle and discontinue using it once they find information access cannot assist them to solve their problems.

\subsubsection{Journalists: tentative use}

Chinese journalists have made tentative use of FOI legislation. Roberts argues that the effectiveness of FOI legislation in China will be limited by the lack of free press. ${ }^{127}$ Callick opines that the chances of Chinese journalists using the FOI

121 Interviews with Chinese citizens (Interview in Person, 17 June 2008).

122 Interviews with Chinese citizens (Interview in Person, 19 June 2008); Qingchang Huang, 'FOI Requests Confronted Difficulties' (in Chinese) People's Daily (Beijing) 12 November 2008, 13.

123 Interviews with Chinese academics (Interview in Person, 12 July 2008); Chang Yuan, 'What Effects of the Implementation of FOI Regulations in Haidian District?' (in Chinese) China Business News (Shanghai) 11 June 2008, A06.

124 Interview with Chinese Government Officials (Interview in Person, 18 June; 23 July 2008).

125 Hongchao Lin, 'What Factors Impede FOI Lawsuits' (in Chinese) Legal Daily (Beijing) 4 December 2008, 3.

126 Ibid.

127 Alasdair Roberts, Blacked out: Government Secrecy in the Information Age (1 ${ }^{\text {st }}$ ed, 2006) 121. 
Regulations are 'very slim,. ${ }^{128}$ This does not mean that Chinese journalists have not responded to FOI legislation now that media competition has increased and Chinese media groups enjoy greater freedom to publish. ${ }^{129}$ At this stage, Chinese journalists remain concerns over the sensitivity and likelihood of access, to government information, ${ }^{130}$ and so their use of FOI is cautious. Even though journalists apply for government information, they focus on information that is largely permitted (Appendix 9).

During the first six months after implementation of the FOI Regulations, Chinese journalists showed interest in access to information, but they had much less interest in filing direct requests than that in reporting government non-compliance and following it up. Weak press freedom was one factor. Chinese journalists were reluctant to use FOI legislation because they had limited capacity to act on the information sought. The controlling flow approach taken by the government also resulted in low direct use of FOI legislation. Like their counterparts in western democracies with long practice for FOI, Chinese journalists were most likely to face the problems coming from government agencies, such as long processing time, high fees, wholesale redactions and sweeping exemptions; ${ }^{131}$ and those stemming from themselves, such as heavy reliance on personal relationships, unwillingness to undertake difficult tasks and concern about readership (see 1.3.1). ${ }^{132}$

128 Rowan Callick, 'Chinese FOI Act Tied by Red Tape' The Australian (Sydney) 1 May 2008, 32.

129 Hachten and Scotton assert that ' $[w]$ hen the Communist leaders told government newspapers they had to start paying their own way, Chinese editors got much more freedom to publish material that would attract readers'. The publication of evening tabloids have prepared the ground for editors to 'publish almost anything they think will attract readers'. See William Hachten and James Scotton, The World News Prism: Global Information in a Satellite Age ( $7^{\text {th }}$ ed, 2006) 104.

130 In an interview with a Chinese government official, she said that several journalists went to her office and raised a similar question, 'is that true that you will answer our requests?', after the FOI Regulations took effect. Interviews with a Chinese government official (Interview in Person, 1 August 2008).

131 Simon James, 'The Potential Benefits of Freedom of Information' in Richard Chapman and Michael Hunt (eds), Open Government in a Theoretical and Practical Context (2006) 27, 27-8; Martin Rosenbaum, 'Open to Question - Journalism and Freedom of Information' (2004) 9 Communications Law 126, 131; Stephen Lamble, Computer-Assisted Reporting and Freedom of Information (D Phil Queensland University, 2002).

132 Jack Herman, The Urgent Need for Reform of Freedom of Information in Australia (Speech delivered at Conference on Public Right to Know, Sydney, 21 August 2004); Kavi 
Furthermore, FOI reform that emphasises information flow rather than media reform has caused Chinese journalists to be concerned over the use of FOI legislation. Thus, they applied for government information as ordinary citizens, rather than as journalists. This undoubtedly limited their use of FOI legislation as an investigative tool.

\subsubsection{Legal professionals: major requesters of public information}

During the first six months after implementation of the FOI Regulations, Chinese legal professionals were the most frequent requesters in China (Appendix 10). Their requests have the following four features. First, a wide range of legal professionals, such as lawyers, law academics and students, used FOI legislation to access government information. In particular, Chinese lawyers showed special interest in requesting information. Second, their requests were primarily for information in the public interest. The information sought covered a wide range of areas, such as the use of charges and public funds, and the exercise of administrative power. Third, legal professionals played an educational role in promoting information access. Professor Xixin Wang and his colleagues aimed at boosting the use of FOI legislation through their requests. ${ }^{133}$ Hongxiang Wen, a Shenyang lawyer, said that his requests were largely for teaching ordinary citizens how to request government information. ${ }^{134}$ Fourth, legal professionals understood how to work closely with media outlets in reporting the progress of their requests, thus bringing about a maximum propaganda effect.

Chongkittavorn, 'Thai Journalists and Access to Information' (Paper presented at Conference on Freedom of Information and Civil Society in Asia, Tokyo, 13-14 April 2001); Rick Snell, 'FOI and the Delivery of Diminishing Returns, or How Spin-Doctors and Journalists Have Mistreated a Volatile Reform' (2002) 3 The Drawing Board: An Australian Review of Public Affairs 187, 1989.

133 Shuming Li, Three Professors at Beijing University Watched Closely on the Tolls of Beijing Airport Expressway (in Chinese) (2008) Xinhua Net <http://big5.xinhuanet.com/gate/big5/news.xi nhuanet.com/legal/2008-06/18/content_8389725.htm> at 20 October 2008.

134 Xiaobo Wang, 'The First FOI Request for Government Financial Accounts in Northeast China Submitted' (in Chinese) Commercial Times (Shenyang) 25 October 2008, A03. 
Chinese legal professionals have an advantage over other groups when using FOI legislation. They have greater professional knowledge as they are likely to know which information is needed and which government agency holds the information, as well as how to use FOI legislation. They, especially lawyers, are also wealthier and more independent than other groups, and so have greater capacity and willingness to request public information. The use of FOI legislation by Chinese legal professionals is a positive response to the impetus of law-based administration for FOI reform in China, though they may use FOI legislation as part of their private commercial lawsuits. However, the use of FOI legislation by legal professionals is largely individualised. It is necessary to initiate a coalition of active FOI requesters to apply for public information in the future (see 11.5).

\subsection{Conclusion}

This chapter argues that the prospects for effective Chinese FOI reform, simply measured by reactive disclosure or the pull aspect of FOI (see 1.3.3), appear limited in the foreseeable future. The level of non-compliance with access requests for information that is not required to be proactively disclosed is currently high. The government's controlling flow approach to manage FOI requests is bolstered by courts, as shown by the various procedural and substantive restrictions placed on FOI lawsuits. This controlling flow approach thus constrains the role that demand side players, especially journalists and lawyers, can play. Ordinary citizens have found the access mechanism an impractical and unrealistic tool for solving their problems. Journalists have been largely restricted to reporting on government non-compliance. Legal professionals have used FOI legislation in a largely individualised way. Concern over compliance issues in China (see 1.3.2) is derived from this excessive focus on government non-compliance with reactive disclosure. 


\section{1: CONCLUSION}

\subsection{Introduction}

The purpose of this thesis is to more thoroughly analyse the Chinese FOI phenomenon. This thesis has used information flow analysis to examine this strange and intriguing phenomenon (see 1.0). It has argued that a sufficient understanding of the adoption of FOI legislation in China cannot be achieved without focusing on the capacity to accept FOI, through examining the development of local information flow over time due to changed social, political, legal and economic conditions. It has also argued that a sufficient understanding of the prospects for the implementation of FOI legislation in China cannot be achieved until equal attention is paid to both the push and pull aspects of information flow.

\subsection{Information flow analysis: explaining the adoption of FOI legislation in China}

Information flow analysis has been demonstrated in this thesis to have the power to explain the apparent paradox of the introduction of FOI legislation into China. This analysis, which focuses on the dynamic interaction between one stream of information flow (push) and another stream (pull) in an information environment, has been created and utilised in this thesis to examine the gradual development of China's capacity to accept FOI. The use of a new and effective explanatory model is necessary, because the explanatory models of accountability deficit, globalization, economic growth and anti-corruption have been arguably inadequate for an understanding of China's FOI phenomenon (see 1.2). Information flow analysis enables an adequate understanding (see Chapters 2, 3, 4 and 5). 
By applying information flow analysis, this thesis has demonstrated that China gradually increased its capacity to accept FOI through the move from an emphasis on proactive disclosure to one on reactive disclosure. This capacity increased after the formation of multiple paths for information flow in the longstanding secretive Chinese information environment (see Chapter 3). Two decades of Openness in Government Affairs coupled with a long term democratisation process also improved information flow between citizens and the state, thus increasing government receptivity to an access mechanism (see Chapter 4). Moreover, the focus for administrative law reforms moved to ex ante and procedural controls of government power improved information flow in the Chinese information environment. This thus raised China's capacity to accommodate FOI (see Chapter 5). In addition, economic growth and anti-corruption efforts were important rationales for increasing China's capacity to support FOI due to the advocacy of key individuals or agencies (see Chapter 6). However, these two driving forces played only a limited and indirect role in improving information flow. From this point of view, these two motives should be allocated important but secondary roles in understanding the development of FOI in China. Social, political and legal motives should be accorded central roles.

The thesis has argued that the gradual development of government receptivity to FOI (see Chapter 7), which began with the acceptance of proactive disclosure and then recognised the importance of reactive disclosure, resulted in China adopting a push model of FOI legislation with an emphasis on proactive disclosure (see Chapter 8). This model has accepted reactive disclosure as a basic element in improving information flow, but reduced the significance of reactive disclosure in this process.

This thesis has shown the explanatory power of information flow analysis for understanding the apparent paradox of the Chinese FOI phenomenon. The explanatory power has come from a dynamic and broad approach to examination of an FOI phenomenon. This analysis has not isolated FOI from a broad information environment, or viewed FOI as a timeless phenomenon. The application of information flow analysis to the Chinese case is the first significant step in gaining a better understanding of the divergence of FOI developments around the globe. 


\subsection{Information flow analysis: understanding the implementation of FOI legislation in China}

Apart from its capacity to explain the adoption of FOI legislation, this thesis has argued that information flow analysis also has the potential to improve the current compliance analysis, by moving toward a broad, dynamic and cross-jurisdictional analysis of FOI performance (see 1.3 and 2.4). The undue focus on reactive disclosure in the Roberts-Snell compliance analysis model limits its application to analysis of compliance issues in China, because the specifics of China's FOI reform, such as internally generated reform and the push model, have not been taken into account (see 1.3.3). This thesis has thus revised the compliance analysis model through the incorporation of the push and pull focus to allow a more effective and dynamic analysis of compliance issues in China (see 1.3.3).

By applying this revised compliance analysis model, the thesis has demonstrated that government willingness and capability, in conjunction with a push model of FOI legislation, can ensure a certain level of compliance with proactive disclosure requirements (see 9.1 and 9.2). This level of compliance has increased since active players on the demand side have been willing and able to redress government noncompliance with proactive disclosure via access requests (see 9.4). Yet the thesis has shown that the prospects for reactive disclosure of information that is not required to be proactively disclosed are limited in China in this early stage of implementation. A controlling flow approach to information requests has reflected the fact that government willingness to comply remains low (see 10.1). Furthermore, both the capacity and willingness of demand side players to use FOI legislation for information outside the scope of proactive disclosure have also been limited (see 10.2 and 10.3).

In this thesis, information flow analysis has been utilised to improve understanding of compliance issues in China. This analysis has indicated that the two-directional nature of FOI, the push and pull aspects of information flow, should be recognised in a compliance analysis model. Compliance with the push aspect of information flow is 
equally important to compliance with the pull aspect.

\subsection{FOI: moving from a beneficiary to a contributor to the Chinese information environment}

By applying information flow analysis, the thesis has demonstrated that FOI was first a beneficiary of, and then a contributor to the Chinese information environment (see 3.3 and 9.2). In order to improve the contributor role of FOI, it is necessary to upgrade the FOI Regulations to FOI law, through improving and strengthening the push nature under the Regulations. Future FOI law should move the factors undermining the push nature (see Chapter 8 ) by explicitly authorising an access right, deleting the purpose requirement for access requests, limiting and clarifying exemptions, and allowing a maximum disclosure principle.

Furthermore, the future of FOI reform should continue focusing on the supply side, which is the key to success in China. It is necessary to establish effective measures to sustain a constant strong central political commitment to FOI, and to maintain the interest of various transparency advocacy groups (see 9.1.1). Demand side players, both domestic and international non-government organisations, can cooperate with supply side drivers to create a more favourable environment for the implementation of FOI legislation in China. Apart from this, demand side players should also assist in improving the level of compliance in China, by focusing on rectification of noncompliance with proactive disclosure requirements. They can use this success as a tool for boosting public confidence with regard to reactive disclosure. It is also necessary to establish professional associations to provide training of potential requesters, increase public awareness of FOI and assess the degree of government compliance from a user perspective.

\subsection{Conclusion}

This thesis began with an inquiry as to whether or not China's FOI is a strange and intriguing phenomenon. By applying information flow analysis, it has argued that China's FOI is hardly strange, as it is deeply attached to social, political, legal and 
economic contexts of information flow in recent Chinese history. As a beneficiary of the gradually improving Chinese information environment, FOI is now becoming a contributor to this environment. Furthermore, China's FOI is far more intriguing than is currently recognised, as it is unique and has not been sufficiently understood.

The case study of China's FOI in this thesis has demonstrated that information flow is an effective analytical tool for coherently examining both the adoption and implementation of FOI legislation in a jurisdiction. In the future, a better understanding as to whether FOI legislation can be adopted or implemented should not ignore its interrelation with other streams of information flow in a broad information environment. This thesis thus calls for more empirical research to apply and develop information flow analysis. 


\section{APPENDICES}

\section{Appendix 1: Participant information sheet}

Title of investigation: Freedom of information reform in China: Information flow analysis

\section{Invitation}

You are invited to participate in a research study of Freedom of Information (FOI) reform in China. This study is being conducted by Weibing Xiao, a $\mathrm{PhD}$ student at the University of Tasmania's (UTAS) Faculty of Law.

\section{1. 'What is the purpose of this study?'}

This research seeks to more thoroughly analyse the Chinese FOI phenomenon. Its specific aims are to:

1.1 Better understand the adoption of FOI legislation in China. This thesis examines the nature and extent of the driving forces behind FOI reform in China;

1.2 Better elucidate the legislative process of FOI in China. This research examines the process of gradual legislative reforms leading up to the introduction of FOI legislation in China;

1.3 Analyse a limited push model of FOI legislation in China; and

1.4 More effectively assess the implementation of FOI legislation in China, and evaluate the strengths and weaknesses in the enforcement process.

\section{2. 'Why have I been invited to participate in this study?'}

You are invited to participate in this study because you have been identified from the literature, public records and discussions as one of the key persons that deal with issues pertaining to such matters. Rest assured that we have not accessed your personal contact details or any other information protected by privacy law.

\section{3. 'What does this study involve?'}

If you agree to participate in this study, it will involve an interview conducted by me.

The interview will be for approximately 60-90 minutes at a time and place convenient to you. My preference is to undertake the interview in person, but arrangements can be made for the interview to be conducted by email, fax or phone.

The interview will be recorded and you have the opportunity to peruse a transcript of your data, so as to edit, modify or withdraw it if necessary.

\section{4. 'Is my participation in this study entirely voluntary?'}

It is important that you understand that your involvement in this study is voluntary. While I would be pleased to have you participate, I respect your right to decline. There will be no consequences to you if you decide not to participate. If you decide to discontinue participation at any time, you may do so without providing an explanation. All information will be treated in a confidential manner, and your name will not be used in any publication arising out of the research. 


\section{Are there any possible benefits from participation in this study?}

The findings of this research may create flow-on benefits for your own research about the reform and improvement of FOI legislation in China. We will be interested to see if you experience any other benefits from this study.

It is possible that the results of this study will flow into law reform and future research on FOI, particularly, in China.

\section{Are there any possible risks from participation in this study?}

Some of the information sought in the interview may be potentially sensitive. Please note that you are entitled to decline to address any questions(s) for any reason(s) or to place limitations on the use and disclosure of any information you supply.

Please note that your identity and the name of your organisation will be mentioned in the thesis. However, if you do not wish to be identified or you do not wish for your organisation to be identified, please make this selection using the consent form (this is attached). In this event, your identity will be treated as confidential by the researchers and your contribution will be protected in a fashion that ensures anonymity.

Please note, however, that there is still potential for identification even if there is the use of anonymity in certain instances, for example, if you are the only leader in the organisation.

All data collected will be stored in a secure electronic format or locked cabinet at the University of Tasmania's Faculty of Law for five years, after which the data will be destroyed.

\section{What if I have questions about this research?}

If you would like to discuss any aspect of this study please feel free to contact me at Tel: +0086 213922 5221, email: xiaow@utas.edu.au. Alternatively, you may contact my supervisors at University of Tasmania:

Mr. Rick Snell (Tel: +61 36226 2062, email r.snell@utas.edu.au .

Prof. Donald Chalmers (Tel: +6136226 2071, email: Don.Chalmers@utas.edu.au .

Any of us would be happy to discuss any aspect of the research with you. Once we have analysed the information we will be mailing / emailing you a summary of our findings. You are welcome to contact us at that time to discuss any issue relating to the research study.

This study has been approved by the Tasmanian Health and Medical Human Research Ethics Committee. If you have concerns or complaints about the conduct of this study should contact the Executive Officer of the HREC (Tasmania) Network on +61 362267479 or email human.ethics@utas.edu.au. The Executive Officer is the person nominated to receive complaints from research participants. You will need to quote H9865. Alternatively, you may contact the Department of Research at Shanghai University of Political Science and Law on +0086 2139225085 or email kevan@shupl.edu.cn.

\section{Thank you for taking the time to consider this study.}

If you wish to take part in it, please sign the attached consent form.

This information sheet is for you to keep. 


\section{Appendix 2: Consent form}

\section{Title of Project: Freedom of information reform in China: Information flow analysis}

1. I have read and understood the 'Information Sheet' for this project.

2. The nature and possible effects of the study have been explained to me.

3. I understand that the study involves participation in an audio-taped interview which will take about $60-90$ minutes.

4. I understand that participation may involve disclosure of some sensitive information but I understand that I can elect not to address any question and I can specify how my response is to be reported.

5. I understand that all research data will be securely stored on the University of Tasmania premises for five years and will then be destroyed.

6. Any questions that $I$ have asked have been answered to my satisfaction.

7. I agree that research data gathered from me for the study may be published on the understanding that (tick one):

$\square$ Both I and the organisation I present will be identified

$\square$ Both $I$ and the organisation cannot be identified as participants.

8. I understand that any information I supply to the researcher(s) will be used only for the purposes of the research.

9. I agree to participate in this investigation and understand that I may withdraw at any time without any effect, and if I so wish, may request that any data I have supplied to date be withdrawn from the research.

Name of Participant:

Signature: Date:

\section{Statement by Investigator}

I have explained the project \& the implications of participation in it to this volunteer and I believe that the consent is informed and that he/she understands the implications of participation

If the Investigator has not had an opportunity to talk to participants prior to them participating, the following must be ticked.

The participant has received the Information Sheet where my details have been provided so participants have the opportunity to contact me prior to consenting to participate in this project.

Name of Investigator

Signature of

Investigator

Name of investigator

Signature of investigator

Date 


\section{Appendix 3: China's Freedom of Information Regulations}

An unofficial English version of China's Freedom of Information Regulations translated by the China Law Centre, Yale Law School

\section{http://www.law.yale.edu/documents/pdf/Intellectual_Life/CL-OGI-Regs-English.pdf}

\section{Key articles related to minimum standards of proactive disclosure (extracted from the preceding version)}

Article 10 requires government agencies at or above the county level to put emphasis on proactive disclosure of the following government information: 1. Administrative regulations, rules, and normative documents; 2. Plans for national economic and social development, plans for specific projects, plans for regional development and related policies; 3 . Statistical information on national economic and social development; 4 . Reports on financial budgets and final accounts; 5. Items subject to an administrative fee and the legal basis and standards therefor; 6. Catalogues of the government's centralised procurement projects, their standards and their implementation; 7. Matters subject to administrative permission and their legal bases, conditions, quantities, procedures and deadlines and catalogues of all the materials that need to be submitted when applying for the administrative permission, and the handling thereof; 8. Information on the approval and implementation of major construction projects; 9. Policies and measures on such matters as poverty assistance, education, medical care, social security and job creation and their actual implementation; 10. Emergency plans for, early warning information concerning, and counter measures against sudden public events; and 11. Information on the supervision and inspection of environmental protection, public health, safe production, food and drugs, and product quality.

Article 11 adds four extra categories of information for government agencies at the county level to disseminate: 1 . Important and major matters in urban and rural construction and management; 2. Information on operation of social and public interest business; 3 . Information on land requisition or land appropriation, household demolition and resettlement, and the distribution and use of compensation or subsidy funds relating thereto; and 4. Information on the management, usage and distribution of social donations in funds and in kind for emergency and disaster relief, special care for families of martyrs and military service personnel, and assistance to poverty stricken and low income families. 
Article 12 requires township government agencies to lay stress on disseminating the following information: 1 . Information on implementation of rural work policies of the state; 2 . Information on fiscal income and expenses and the management and use of various specialised funds; 3. Overall township (town) land use plans and information on the verification of land to be used by farmers for their primary residences; 4. Information on land requisition or land appropriation, household demolition and resettlement, and the distribution and use of compensation or subsidy funds; 5. Information on township (town) credits and debts, fund raising and labor levies; 6 . Information on the distribution of social donations in funds and in kind for emergency and disaster relief, special care for families of martyrs and military service personnel, and assistance to poverty stricken and low income families; 7 . Information on contracting, leasing and auctioning of township and town collectively owned enterprises and other township and town economic entities; and 8. Information on implementation of the family planning policy. 
Appendix 4: FOI legislation in comparatively larger cities

\begin{tabular}{|l|r|r||}
\hline CITY & DATE PASSED & DATE EFFECTIVE \\
\hline Guangzhou & 6 November 2002 & 1 January 2003 \\
\hline Hangzhou & 15 April 2004 & 1 October 2004 \\
\hline Changchun & N/A & 30 October 2004 \\
\hline Ningbo & 28 September 2004 & 1 November 2004 \\
\hline Chengdu & 4 March 2004 & 1 May 2004 \\
\hline Kunming & 8 April 2004 & 1 May 2004 \\
\hline Wuhan & 17 May 2004 & 1 July 2004 \\
\hline Datong & 30 March 2004 & 1 August 2004 \\
\hline Anshan & 23 September 2004 & 1 January 2005 \\
\hline Haikou & N/A & 1 June 2005 \\
\hline Guiyang & 25 April 2005 & 1 January 2006 \\
\hline Zhengzhou & 8 July 2005 & 1 October 2005 \\
\hline Wululmuqi & 26 September 2005 & 1 November 2005 \\
\hline Suzhou & 25 October 2005 & 1 January 2006 \\
\hline Handan & 16 May 2006 & 18 May 2006 \\
\hline Benxi & 20 May 2006 & 1 July 2006 \\
\hline Shenzhen & 22 September 2006 & 1 September 2006 \\
\hline \hline
\end{tabular}

\section{Appendix 5: FOI legislation in provinces and special municipalities}

\begin{tabular}{|l|r|r|}
\hline \hline PROVINCE & DATE PASSED & DATE EFFECTIVE \\
\hline Shanghai & 20 January 2004 & 01 May 2004 \\
\hline Chongqing & 2 June 2004 & 01 July 2004 \\
\hline Hubei & 18 May 2004 & 01 July 2004 \\
\hline Jilin & 22 July 2004 & 05 September 2004 \\
\hline Hebei & 29 March 2005 & 01 July 2005 \\
\hline Guangdong & 29 July 2005 & 01 October 2005 \\
\hline Hainan & 15 August 2005 & 01 October 2005 \\
\hline Shanxi & 10 December 2005 & 1 January 2006 \\
\hline Liaoning & 14 December 2005 & 1 February 2006 \\
\hline Heilongjiang & 30 December 2005 & 1 April 2006 \\
\hline Jiangsu & 07 August 2006 & 01 September 2006 \\
\hline Sichuan & 12 September 2006 & 12 September 2006 \\
\hline
\end{tabular}


Appendix 6: FOI proposals submitted by deputies of the National People's Congress

\begin{tabular}{||l|l|l||}
\hline DEPUTIES & YEAR & SESSION \\
\hline $\begin{array}{l}\text { Qi Cai and other deputies from Fujian } \\
\text { Province }\end{array}$ & March 2002 & $\begin{array}{l}\text { The Fifth Session of the } \\
\text { Ninth NPC }\end{array}$ \\
\hline $\begin{array}{l}\text { Suzhi Chen and other deputies from } \\
\text { Niaoning Province }\end{array}$ & March 2002 & $\begin{array}{l}\text { The Fifth Session of the } \\
\text { Ninth NPC }\end{array}$ \\
\hline $\begin{array}{l}\text { Zhihai Li and other deputies came from } \\
\text { Zhejiang Province }\end{array}$ & March 2003 & $\begin{array}{l}\text { The First Session of the } 10^{\text {th }} \\
\text { NPC }\end{array}$ \\
\hline $\begin{array}{l}\text { Huiqiang Zhen and other deputies from } \\
\text { Shanghai Special Municipality }\end{array}$ & March 2004 & $\begin{array}{l}\text { The Second Session of the } \\
10^{\text {th }} \text { NPC }\end{array}$ \\
\hline $\begin{array}{l}\text { Zhong Yang and other deputies from Shanxi } \\
\text { Province }\end{array}$ & March 2004 & $\begin{array}{l}\text { The Second Session of the } \\
10^{\text {th }} \text { NPC }\end{array}$ \\
\hline $\begin{array}{l}\text { Zhongchuan Dai and other deputies from } \\
\text { Fujian Province }\end{array}$ & March 2005 & $\begin{array}{l}\text { The Third Session of the } \\
10^{\text {th }} \text { NPC }\end{array}$ \\
\hline $\begin{array}{l}\text { Yongqiu Zhao and other deputies from } \\
\text { Hubei Province }\end{array}$ & March 2006 & $\begin{array}{l}\text { The Fourth Session of the } \\
10^{\text {th }} \text { NPC }\end{array}$ \\
\hline \hline
\end{tabular}

Source: The National People's Congress (NPC)

Appendix 7: The main economic indicators in 1978 and in 2007

\begin{tabular}{|l|l|l||}
\hline \multirow{2}{*}{} & \multicolumn{2}{|c|}{ YEAR AND FIGURES } \\
\cline { 2 - 3 } & \multicolumn{1}{|c|}{$\mathbf{1 9 7 8}$} & \multicolumn{1}{|c|}{$\mathbf{2 0 0 7}$} \\
\hline Foreign exchange reserves & \$US0.17 billion & \$US1.53 trillion \\
\hline Gross Domestic Product & \$US60.50 billion & \$US3.43 trillion \\
\hline Per capita Gross Domestic Product & 379 yuan (\$US48.62) & 17,657 yuan (\$US2456) \\
\hline Per capita disposable income & $\begin{array}{l}\text { Urban residents: 343 yuan } \\
\text { (\$US44) }\end{array}$ & 13,786 yuan (\$US1918) \\
\cline { 2 - 3 } & $\begin{array}{l}\text { Farmers: 134 yuan } \\
\text { (\$US17.19) }\end{array}$ & 4140 yuan (\$US576) \\
\hline
\end{tabular}

Source: The National Bureau of Statistics 
Note: there are no official statistics about the types of FOI requesters. The cases in the appendices $(8,9$ and 10$)$ were collected for this research through a wide range of sources.

\begin{tabular}{||l|l||}
\hline \multicolumn{1}{|c|}{ PURPOSE } & \multicolumn{1}{c|}{ REQUEST } \\
\hline \multirow{3}{*}{$\begin{array}{l}\text { To examine } \\
\text { whether their } \\
\text { interests are } \\
\text { violated or not }\end{array}$} & $\begin{array}{l}\text { On 4 May 2008, Youjian Huang and his colleagues applied for a } \\
\text { survey report on the restructure of a water supply company. }\end{array}$ \\
\cline { 2 - 2 } & $\begin{array}{l}\text { On 4 May 2008, Zhou filed a request for a building dismantlement } \\
\text { licence and other necessary legal documents. }\end{array}$ \\
\cline { 2 - 3 } & $\begin{array}{l}\text { On 26 May 2008, Yaofang Xu and 67 other villagers filed a request to } \\
\text { the Yuyao Government of Zhejiang Province for information on land } \\
\text { transfer. }\end{array}$ \\
\cline { 2 - 3 } & $\begin{array}{l}\text { In August 2008, Tianlin Liu requested information on his village's } \\
\text { household demolition, resettlement and compensation in 2000. }\end{array}$ \\
\hline $\begin{array}{l}\text { To better } \\
\text { understand their } \\
\text { personal legal } \\
\text { matters }\end{array}$ & $\begin{array}{l}\text { Mingxin Zhu lodged her request to the Beijing Municipal Public } \\
\text { Security Bureau for information on the progress of her daughter's } \\
\text { criminal case. }\end{array}$ \\
\cline { 2 - 2 } & $\begin{array}{l}\text { Family members of the victims of Baotou air crash in 2004 applied to } \\
\text { the Civil Aviation Administration of China for information on the } \\
\text { survey of this crash. }\end{array}$ \\
\hline $\begin{array}{l}\text { To know more } \\
\text { about how the } \\
\text { government } \\
\text { processes their } \\
\text { business affairs }\end{array}$ & $\begin{array}{l}\text { On 3 June 2008, Bin Qiao requested information on the Shenzhen } \\
\text { Justice Bureau's processing of his complaint about a public notary } \\
\text { office's rejection of his notary application. }\end{array}$ \\
\hline
\end{tabular}

1 The government refused their request. The court did not accept their legal action. See Wenming Zhao, 'Reflecting on the First Lawsuit after FOI Regulations Took Effect' (in Chinese) Legal Daily (Beijing) 6 May 2008, 8.

2 The government did not answer his request until he filed a lawsuit in the court. See Hong Chen et al, The First FOI Lawsuit in Nantong City Was Finalised (in Chinese) (2008) the Rugao Government <http://www.rugao.gov.cn/html/2008/08/20080818094116-1.htm> at 20 October 2008.

3 The government rejected their request, but the administrative reconsideration agency supported their application. See Junxiu Wang, 'Sixty-Eight Villagers in Yuyao City of Zhejiang Province Win Their FOI Lawsuit' (in Chinese) China Youth Daily (Beijing) 10 October 2008, 6.

4 The government refused his request on the ground that the information sought did not exist. See Hua Zhang and Shupei Song, 'The First FOI Case in Zhengzhou after Implementation of FOI Regulations' (in Chinese) Zhengzhou Evening (Zhengzhou) 7 August 2008, A12.

5 Mingxin Zhu is the mother of Ling Zhu who became the victim of an unsolved 1995 thallium poisoning case. The government has not yet given her any response. See Jun Ma et al, 'FOI Regulations Came into Force on 1 May: Obtaining a Real Picture of FOI' (in Chinese) Youth Weekend (Beijing) 15 May 2008, A08.

6 The government rejected their request. See Ma et al, above $\mathbf{n} 5$.

7 The government replied him in an unofficial way. See Lian Zhong, The Shenzhen Justice Bureau Was Sued for Replying to an FOI Request via a Private Email (in Chinese) (2008) $21^{\text {st }}$ Centuries Net <http://www.21cbh.com/HTML/2008/8/26/HTML_X87778CRQ1PG.html> at 22 October 2008. 


\begin{tabular}{||l|l|}
\hline \multicolumn{1}{|c|}{ PURPOSE } & \multicolumn{1}{|c|}{ REQUEST } \\
\hline $\begin{array}{l}\text { To solve their } \\
\text { outstanding } \\
\text { issues with the } \\
\text { government }\end{array}$ & $\begin{array}{l}\text { On 12 May 2008, Jin submitted a request to the Dongcheng District } \\
\text { Housing Management Bureau for information on the registration } \\
\text { records concerning over 50 houses which were purchased by her father } \\
\text { and subsequently taken over by the government. }\end{array}$ \\
\hline $\begin{array}{l}\text { To claim benefits } \\
\text { from the } \\
\text { government }\end{array}$ & $\begin{array}{l}\text { On 12 September 2008, Yang filed a request to a personnel department } \\
\text { for information on how his pension was calculated. }\end{array}$ \\
\cline { 2 - 2 } & $\begin{array}{l}\text { After the FOI Regulations took effect, veterans and former } \\
\text { government officials requested their personnel files stored at the } \\
\text { archives in order to claim benefits provided by the government. }\end{array}$ \\
\hline
\end{tabular}

8 The government refused her request. See Junjie Chen, 'The Beijing Court Accepted the First FOI Lawsuit' (in Chinese) The Beijing News (Beijing) 19 June 2008, A22.

9 The government rejected his request, but the administrative reconsideration agency supported the request. See Gensheng Lv, 'The First FOI Request Lodged in Taiyuan City for Protecting the Access Right' (in Chinese) Taiyuan Daily (Taiyuan) 14 November 2008, 3.

10 On many occasions, government agencies replied that the information sought did not exist. Interview with Archivists (Interview in person, 21 July; 30 July 2008). 


\section{Appendix 9: Examples of Chinese journalists' use of FOI legislation}

\begin{tabular}{||l|l||}
\hline & The information sought \\
\hline A Jiefang Daily journalist & $\begin{array}{l}\text { For information on the scope of site selection for the } \\
\text { Shanghai Metro Line 10. }\end{array}$ \\
\hline $\begin{array}{l}\text { A Henan Business Daily } \\
\text { journalist }\end{array}$ & $\begin{array}{l}\text { For information regarding a public transportation } \\
\text { company's financial reports to justify whether or not the } \\
\text { company's increase in bus fares was reasonable. }{ }^{12}\end{array}$ \\
\hline $\begin{array}{l}\text { A China Business Herald } \\
\text { News Weekly journalist }\end{array}$ & $\begin{array}{l}\text { For information on the process of examining and approving } \\
\text { a company's application for land use. } .^{13}\end{array}$ \\
\hline $\begin{array}{l}\text { Southern Weekend } \\
\text { journalists }\end{array}$ & $\begin{array}{l}\text { For information on real estate development agencies' land } \\
\text { use certificates and mortgage of land-use rights. }\end{array}$ \\
\hline Xin'an Evening journalists & $\begin{array}{l}\text { For various information to capture a real picture of the } \\
\text { operation of the FOI Regulations in Anhui province. }\end{array}$ \\
\hline $\begin{array}{l}\text { A China Industrial } \\
\text { Economy News journalist }\end{array}$ & $\begin{array}{l}\text { For information on a luxurious official building in } \\
\text { Dongguan City. }{ }^{16}\end{array}$ \\
\hline
\end{tabular}

11 Henan Zhen, 'Shortcomings for FOI: A Citizen's Fight with the Planning Bureau' (in Chinese) Procuratorial Daily (Beijing) 4 August 2008, 7.

12 Yanyan Lu and Lu Yang, 'Non-Compliance with FOI Regulations Found at the Sub-National Level' (in Chinese) Henan Business Daily (Shijiangzhuang) 12 June 2008, A10.

13 Non-Disclosure Problems for Several Local Governments (in Chinese) (2008) Xinhua Net $<$ http://news.xinhuanet.com/politics/2008-07/30/content_8851290.htm> at 10 October 2008.

14 Lin Su et al, 'Journalists' Real Experiences of "Non-Disclosure Information"' (in Chinese) Southern Weekend (Guangzhou) 10 July 2008, A05.

15 Lixia Xia et al, 'Let Us Put a Question on Openness in Government Affairs: Are FOI Offices Transparent Enough?' (in Chinese) Xin'an Evening (Hefei) 20 October 2008, A3.

16 Youyi Zhang, 'A Journalist Protects His Right to Interview according to FOI Regulations' (in Chinese) Legal Daily (Beijing) 23 March 2008, 2. 


\section{Appendix 10: Examples of Chinese legal professionals' use of FOI legislation}

\begin{tabular}{||l|l||}
\hline REQUESTER & THE INFORMATION SOUGHT \\
\hline A Beijing lawyer & $\begin{array}{l}\text { For information on the legal basis and use of airport construction } \\
\text { fees. }{ }^{17}\end{array}$ \\
\hline A Beijing lawyer & For information on investment in expressways. ${ }^{18}$ \\
\cline { 2 - 3 } & $\begin{array}{l}\text { For information concerning an audit report on the operation and } \\
\text { administration of 18 province and city toll roads. }\end{array}$ \\
\cline { 2 - 3 } & $\begin{array}{l}\text { For information on tuition fees paid to the Shanghai National } \\
\text { Accounting Institute for several senior figures' Executive Master of } \\
\text { Business Administration training courses. }\end{array}$ \\
\hline A Beijing lawyer & $\begin{array}{l}\text { For information on an investigation concerning the disclosure of } \\
\text { controversial pictures of a rare wild South China tiger. }\end{array}$ \\
\cline { 2 - 2 } & $\begin{array}{l}\text { For information on the process of a series of conflicts between } \\
\text { Yang Jia and police officials. }\end{array}$ \\
\hline A Beijing lawyer & $\begin{array}{l}\text { For information on a government agency's structure, function and } \\
\text { working procedures. }\end{array}$ \\
\hline A Shenyang lawyer & $\begin{array}{l}\text { For information concerning the supervision of illegal occupancy } \\
\text { before the completion of residential buildings. }{ }^{24}\end{array}$ \\
\cline { 2 - 2 } & For information on details of financial budgets and final accounts. \\
& ${ }^{25}$ \\
\hline A Shanghai lawyer & $\begin{array}{l}\text { For information on the process of a massive outbreak of EV71 in } \\
\text { Fuyang. }{ }^{26}\end{array}$ \\
\cline { 2 - 3 } & $\begin{array}{l}\text { For information on the prevention and control of water pollution } \\
\text { within the territory of the Huaihe River Valley. }{ }^{27}\end{array}$ \\
\hline
\end{tabular}

17 Dianxue Wang, 'Lawyer's Request on Airport Construction Fees Answered' (in Chinese) The Beijing News (Beijing) 17 July 2008, A23.

18 Haoning Lai, A PhD Candidate at Tisunghua University Took the Shanghai Government to Court for Charging Expressway Tolls (in Chinese) (2005) People.com <http://finance.people.com.cn/GB /1037/3821518.html> at 18 May 2007.

19 Yanxun Liu, 'Suing in the Name of FOI Regulations' (in Chinese) (2008) 21 New Centuries Weekly 46, 46-9.

20 Gang $\mathrm{Li}$, The Leal Action against the Shanghai Government for Refusing to Disclose Information on Tuition Fees Paid for Civil Servants' Executive Master of Business Administration Training Courses (in Chinese) (2008) Public Interest Litigation <http://www.pil.org.cn/article view.asp?uid $=964>$ at 10 October 2008.

21 Jinsong Hao v The Shaanxi Forestry Department (2008) I The Lianhu District People's Court of Xi'an.

22 Jun Ma et al, 'FOI Regulations Came into Force on 1 May: Obtaining a Real Picture of FOI' (in Chinese) Youth Weekend (Beijing) 15 May 2008, A08.

23 Doudou Tian, 'The Government Lost Its FOI Lawsuit for the First Time' (in Chinese) People 's Daily (Beijing) 10 October 2008, 10.

24 Hong Huo, 'A Lawyer in Shenyang City Requested Government Information for the First Time' (in Chinese) Shenyang Daily (Shenyang) 28 July 2008, A02.

25 Xiaobo Wang, 'The First FOI Request for Government Financial Accounts in Northeast China Submitted' (in Chinese) Commercial Times (Shenyang) 25 October 2008, A03.

26 Lian Chen, A Shanghai Lawyer Challenged the Henan Provincial Environmental Protection after the FOI Regulations Came into Force (in Chinese) (2008) Xinhua Net <http://news.xinhuanet.com /legal/2008-05/06/content_8114120.htm> at 7 May 2008 .

27 Ibid. 


\begin{tabular}{||l|l||}
\hline REQUESTER & THE INFORMATION SOUGHT \\
\hline A Ningbo lawyer & $\begin{array}{l}\text { For a letter sent by the Anhui government for instructions about } \\
\text { laws and policies in relation to the establishment of developmental } \\
\text { zones and industrial parks. }\end{array}$ \\
\hline A Luoyang lawyer & $\begin{array}{l}\text { For the ledger of the issue of the } 29^{\text {th }} \text { Olympic commemorative } \\
\text { currency. }\end{array}$ \\
\hline $\begin{array}{l}\text { Professors in law at } \\
\text { Beijing University }\end{array}$ & $\begin{array}{l}\text { For information on the total figure of the Beijing Airport } \\
\text { Expressway tolls and the way they were used. } .^{30}\end{array}$ \\
\hline $\begin{array}{l}\text { Professor in law at } \\
\text { Tstingua University }\end{array}$ & $\begin{array}{l}\text { For information on the seismic intensity distribution map of the } \\
\text { Sichuan earthquake. }\end{array}$ \\
\hline $\begin{array}{l}\text { Law postgraduates at } \\
\text { Xiangtan University }\end{array}$ & $\begin{array}{l}\text { For information on the total figure of bridge tolls and the way they } \\
\text { were used. }{ }^{32}\end{array}$ \\
\hline
\end{tabular}

28 Xudong Qin, An FOI Lawsuit Was Tried with the Anhui Government Being Sued (in Chinese) (2008) Caijing <http://www.caijing.com.cn/2008-10-09/110018705.html> at 10 October 2008.

29 Yihai Zhao and $\mathrm{Nan} \mathrm{Xu}$, 'Is Disclosure of the Details regarding the Issue of the Olympics Commemorative Currency Counted as Secret Divulgence?' (in Chinese) Southern Weekend (Guangzhou) 6 November 2008, C20.

30 Shuming Li, Three Professors at Beijing University Watched Closely on the Tolls of Beijing Airport Expressway (in Chinese) (2008) Xinhua Net <http://big5.xinhuanet.com/gate/big5/news.xi nhuanet.com/legal/2008-06/18/content_8389725.htm> at 20 October 2008.

31 Hujun Li, A Tisunghua Academic Requested Information on Seismic Intensity Distribution Map (in Chinese) (2008) Caijing <http://www.caijing.com.cn/2008-06-13/100069541.html> at 22 October 2008.

32 'The Government Which Rejected An Information Request Became a Defendant' Tianshui Evening (Tianshui) 7 June 2008, 11. 


\section{BIBLIOGRAPHY}

\section{References}

A Chronicle of Significant Events in Government Informatisation (in Chinese) (2003) China Net <http://www.china.com.cn/chinese/zhuanti/283818.htm> at 19 May 2008.

A Citizen's Story about Access to Government Information (in Chinese) (2008) Jiangsu Informatisation <http://www.jsia.gov.cn/Browse/noinfocontent.aspx?id=19 91\&tablename $=$ tnoinfo $>$ at 10 October 2008.

A Historical Overview of Development of Informatisation in China (in Chinese) (2007) E-Government Research <http://e-gov.nsa.gov.cn/digest.asp?articleid=335> at 5 April 2008.

Ackerman, John and Sandoval-Ballesteros, Irma, 'The Global Explosion of Freedom of Information Laws' (2006) 58 Administrative Law Review 85-130.

Aitken, Judith, 'Open Government in New Zealand' in Andrew McDonald and Greg Terrill (eds), Open Government: Freedom of Information and Privacy (1998) $117-42$.

Ali, Ahmad Mukhtar, Freedom of Information in South Asia: Comparative Perspectives on Civil Society Initiative (2003) Journalists for Democracy and Human Rights <http://www.jdhr.org/publications/papers/Mukhtar\%20A\%20Aliedia\%20panel-\%20Editited\%2027.4.pdf> at 25 February 2009.

Allport, Gordon and Postman, Joseph, The Psychology of Rumour ( $1^{\text {st }}$ ed, 1947).

'A Massive Incident Occurred in the Wudu District of the Longnan City' (in Chinese) Gansu Daily (Lanzhou) 18 November 2008, 1.

Article 19, Promoting Practical Access to Democracy: A Survey of Freedom of Information in Central and Eastern Europe (2002) <http://www.article19.org/pdfs/ publications/freedom-of-information-survey-of-central-and-e.pdf $>$ at 25 February 2009.

Right to Know: Principles on Freedom of Information Legislation (1999) <http://www.article19.org/pdfs/standards/righttoknow.pdf> at 1 July 2007.

A Model Freedom of Information Law (2001) $<\mathrm{http} / /$ www.article19.org/pdfs/standards/modelfoilaw.pdf $>$ at 18 August 2007.

'A 70-Year-Old Woman Lost Her Case Which Was the First FOI Case That Was Closed without Ending' (in Chinese) Oriental Outlook (Beijing) 19 August 2005. 
A Summary of the Work of Civil Servants' Resignation and Dismissal (in Chinese) (2003) China Net <http://www.china.com.cn/chinese/zhuanti/gwy/385982.htm > at 11 March 2009.

Australia, Attorney-General's Department, Proposed Freedom of Information Legislation: Report of Interdepartmental Committee, AGPS, Canberra, 1974.

Bambauer, Derek et al, 'Internet Filtering in China in 2004-2005: A Country Study' (Research Publication No 2005-10, Berkman Centre for Internet \& Society at Harvard Law School, 2005).

Ban, Gu, Han Shu: The Biography of Kong Guang. See http://www.guoxue.com/ shibu/24shi/hansu/hsuml.htm.

Banisar, David, Effective Open Government: Improving Public Access to Government Information (2005) OECD <http://www.olis.oecd.org/olis/2005doc.nsf /0/cb40b8eb18975d01c1256fd300582d2d/\$FLLE/JT00181243.PDF> at 11 August 2007.

Freedom of Information around the World 2006: A Global Survey of Access to Government Information Laws (2006) Freedom of Information Organisation <http://www.freedominfo.org/documents/global_survey2006.pdf> at 9 November 2006.

Barzelay, Michael, 'Origins of the New Public Management: An International View from Public Administration/Political Science' in Kathleen McLaughlin and Stephen Osborne (eds), New Public Management: Current Trends and Future Prospects (2001) 15-33.

Bayne, Peter, Freedom of Information: An Analysis of the Freedom of Information Act 1982 (Cth) and a Synopsis of the Freedom of Information Act 1982 (Vic) (1 ${ }^{\text {st }}$ ed, 1984).

Becker, Jasper, 'Comrade Jiang Zemin Does Indeed Seem a Proper Choice' London Review of Books (London) 24 May 2001, 12.

Beijing TRS Information Technology Co., Ltd., Interview with Zhigeng Wang, Director of the Digital Resource and Service Department of the National Library (Beijing, 6 February 2009).

Bennett, Colin, 'Review Article: What Is Policy Convergence and What Causes It?' (1991) 21 British Journal of Political Science 215-33.

, 'Understanding Ripple Effects: The Cross-National Adoption of Policy

Instruments for Bureaucratic Accountability' (1997)10 Governance: An International Journal of Policy and Administration 213-33. 
Globalisation and Access to Information Regimes (2001) Access to Information Review Task Force <http://www.atirtf-geai.gc.ca/paper-globalisation1e.html> at 30 January 2008 .

Bergsten, Fred et al, China's Rise: Challenges and Opportunities ( $1^{\text {st }}$ ed, 2008).

Besley, Timothy et al, 'Mass Media and Political Accountability' in the World Bank (ed), The Right to Tell: The Role of Mass Media in Economic Development (2002) 45-60.

Birkinshaw, Patrick, 'Freedom of Information and Openness: Fundamental Human Rights' (2006) 58 Administrative Law Review 177-218.

Blanton, Thomas, 'The Openness Revolution: The Rise of a Global Movement for Freedom of Information’ (2002) 1 Development Dialogue 7-21.

Bookman, Zachary and Guerrero Amparan, Juan-Pablo, 'Two Steps forward, One Step Back: Assessing the Implementation of Mexico's Freedom of Information Act' (2009) 1 Mexican Law Review 3-51.

Brown, Archie, The Gorbachev Factor $\left(1^{\text {st }}\right.$ ed, 1997).

Brown, Stephen, 'Freedom of Information' (Paper presented at Seminar on Freedom of Information - A Cultural Perspective, Canberra, 21 February 2000).

Cai, Wu, Speech delivered at the Fourth National Spokespersons Training Session, Beijing, 2 December 2005.

Callick, Rowan, 'Chinese FOI Act Tied by Red Tape' The Australian (Sydney) 1 May 2008, 32.

Candler, Brian, 'The Australian Freedom of Information Act: A Personal View' in Robert Gregory (ed), The Official Information Act: A Beginning (1984) 16-30.

Cao, Kangtai and Zhang, Qiong, The Primer on China's FOI Regulations (in Chinese) $\left(1^{\text {st }}\right.$ ed, 2008).

Cao, Yu, 'The Gradual Trend toward Grassroots Democracy' (in Chinese) (2005) 9 People Forum 34-5.

Castells, Manuel, The Rise of the Network Society (1 ${ }^{\text {st }}$ ed, 1996).

, 'Materials for an Exploratory Theory of the Network Society' (2000)

51 British Journal of Sociology 5-24.

Chen, Fuzhi, 'Several Issues in Relation to FOI Regulations (Pt 1)' (in Chinese) (2007) 11 China Public Administration 21-3. 
, 'Several Issues in Relation to FOI Regulations (Pt 2)' (in Chinese) (2008) 1 China Public Administration 21-3.

Chen, Hong et al, The First FOI Lawsuit in Nantong City Was Finalised (in Chinese) (2008) The Rugao Government <http://www.rugao.gov.cn/html/2008/08/ 20080818094116-1.htm> at 20 October 2008.

Chen, Huanchang, Setting up a Correct Role for Audits to Promote New Development of Audit Work (in Chinese) (2003) The National Audit Office <http://www.audit.gov.cn/n1057/n1072/n1342/14784.html> at 5 May 2008.

Chen, Jianfu, Chinese Law: Towards an Understanding of Chinese Law, Its Nature, and Development ( $1^{\text {st }}$ ed, 1999).

Chen, Junjie, 'The Beijing Court Accepted the First FOI Lawsuit' (in Chinese) The Beijing News (Beijing) 19 June 2008, A22.

Chen, Lian, A Shanghai Lawyer Challenged the Henan Provincial Environmental Protection after the FOI Regulations Came into Force (in Chinese) (2008) Xinhua Net <http://news.xinhuanet.com/legal/2008-05/06/content_8114120.htm> at 7 May 2008 .

Chen, Lidan and Chen, Junni, 'On Impediments to Information Flow during the Crisis of the Songhuajiang River Contamination' (in Chinese) (2005) 6 Press Circles 19-22.

Chen, Liping, 'Likely Adoption of FOI Regulations This Year' (in Chinese) Legal Daily (Beijing) 27 September 2006, 1.

Chen, Mo, 'Hanhua Zhou: 'The Key of FOI Regulations Is to Make FOI Become the Duty of the Government' (in Chinese) $21^{\text {st }}$ Century Business Herald (Beijing) 27 April 2007, 1.

Chen, Xuan and Guo, Jinchun, 'Lessons from "Audit Storm" in China' (in Chinese) (2005) 4 Chinese Business Review 1-7.

Chen, Yimin, 'Grassroots Democratisation and Democracy at the Grassroots Level' (in Chinese) (2007) 9 China Reform 27-30.

Cheng, Jie, 'FOI Regulations and Public Libraries' (in Chinese) (2008) 4 Information and Documentation Services 16-8.

, 'Investigation Report on Implementation of Sub-National FOI Rules:

What Can We Expect Now That FOI Regulations Are in Effect?' (in Chinese) Legal Daily (Beijing) 11 May 2008, 3. 
,' 'Research on the Application of Law to Government Information Disclosure' (in Chinese) (2009) 3 Political Science and Law 28-36.

'Toward Open Society: Examination on Policies Concerning Access to Public Information and Openness in Government Affairs' (in Chinese) (2002) 3 Tsinghua Forum of Rule of Law 460-76.

Cheng, Meidong, Reflection on Major Crises in Contemporary China (in Chinese) ( ${ }^{\text {st }}$ ed, 2008).

Cheng, Zhen, Call for Establishing a Private Channel for Releasing Government Information (in Chinese) (2009) The China Law Library <http://www.chinalaw lib.org.cn/LunwenShow.aspx?CID=20081224141625700185\&AID=200902231953 $02737037 \& \mathrm{FID}=20081224141208467131>$ at 4 May 2009.

Cheung, Arthur, 'China's Administrative Litigation Law' (2005) Autumn Public Law 549-70.

China Central Television, 'The Ministry of Agriculture Denied the Rumour Saying That Bananas Had Viruses Similar to SARS' News $360^{\circ}, 23$ May $2007<\mathrm{http}: / /$ vsearch.cctv.com/plgs_play.php?ref=cctvcomprog_20070523_150648 $7>$ at 2 December 2008.

, 'Guoqing Wang Talks about the Spokesperson System', People in the News, 13 July $2007<\mathrm{http}: / /$ news.cctv.com/china/20070713/109210.shtml> at 7 August 2007.

, 'The Booklet on the Reduction of the Farmers' Burden Was Forbidden to Be Distributed in Jiangxi Province' The 30 Minutes' Economics, 11 November $2000<\mathrm{http} / / / \mathrm{www} . c c t v . c o m /$ financial/jingji/sanji/zhoume/0102_22/z22_17.html > at 22 March 2008.

China Internet Network Information Centre, $19^{\text {th }}$ Statistical Survey Report on the Internet Development in China (2007) <http://www.cnnic.net.cn/download/2007/ cnnic19threport.pdf $>$ at 7 August 2008.

, The $22^{\text {nd }}$ Statistical Survey Report on the Internet Development in China (2008) <http://www.cnnic.cn/download/2008/CNNIC22threport-en.pdf> at 28 November 2008.

Chongkittavorn, Kavi, 'Thai Journalists and Access to Information' (Paper presented at Conference on Freedom of Information and Civil Society in Asia, Tokyo, 13-14 April 2001).

Chu, Chaoxin, 'The Hubei Government Issued a Bulletin on the Government's First Failure in Relation to FOI Lawsuits' (in Chinese) The Beijing News (Beijing) 11 October 2008, A13. 
Clark, David, 'Open Government in Britain: Discourse and Practice' (1996) 16 Public Money \&Management 23-30.

Cohen, Bernard, The Press and Foreign Policy $\left(1^{\text {st }} \mathrm{ed}, 1963\right)$.

Commonwealth, Parliamentary Debates, House of Representatives, 2 April 1981, 1059 (Senator Durack, the Attorney-General of Western Australia).

(Senator Evans).

Parliamentary Debates, House of Representatives, 8 April 1981, 1232

Confucius, Lun $Y u$. See http://www.guoxue.com/jinbu/13jing/lunyu/13j lyml.htm.

Craglia, Massimo and Blakemore, Michael, 'Access Models for Public Sector Information: The Spatial Data Context' in Georg Aichholzer and Herbert Burkert (eds), Public Sector Information in the Digital Age: Between Markets, Public Management and Citizens' Rights (2004) 187-209.

Crano, William, 'Primacy versus Recency in Retention of Information and Opinion Change' (1977) 101 Journal of Social Psychology 87-96.

Cui, Dianchao, 'The Russian Reform Fell into the Trap of Democratisation' (in Chinese) (2000) 1 China National Conditions and Strength 34-5.

Cuillier, David and Piotrowski, Suzanne, 'Internet Information-Seeking and Its Relation to Support for Access to Government Records' (2009) 26 Government Information Quarterly 441-9.

Darch, Colin and Underwood, Peter, 'Freedom of Information Legislation, State Compliance and the Discourse of Knowledge: The South African Experience' (2005) 37 International Information and Library Review 77-86.

Freedom of Information and the Developing World: The Citizen, the State and Models of Openness ( $1^{\text {st }}$ ed, forthcoming 2009).

Declassified Foreign Affairs Archives from between 1956 to 1960 Were Accessible in China (in Chinese) (2006) Xinhua Net<http://news.xinhuanet.com/banyt/200607/19/content_4852638.htm> at 29 March 2008.

Delagrave, Andrée, Creating a Culture of Openness \& Transparency (2001) Access to Information Review Task Force $<$ http://www.atirtf-geai.gc.ca/speeches/ london01-e.html $>$ at 18 August 2009.

Deng, Xiaoping, Selected Works of Xiaoping Deng (Volume II) (in Chinese) (2 ${ }^{\text {nd }}$ ed, 1994). 
1994).

, Selected Works of Xiaoping Deng (Volume III) (in Chinese) $\left(2^{\text {nd }}\right.$ ed,

Deng, Yifu, 'Ten County Deputy Mayors in the Pingjiang County of Hunan Province' (in Chinese) New Express Daily (Guangzhou) 4 December 2008, A26.

Doty, Philip, Freedom of Information in the United States: Historical Foundations and Current Trends (2000) The University of Texas at Austin <www.utexas.edu/ research/tipi/reports2/foia_doty.pdf.> at 8 September 2006.

Dun, Hongqing and Ye, Doudou, The Beginning of FOI Work (in Chinese) (2007) Caijing <http://www.caijing.com.cn/newcn/ruleoflaw/other/2007-04-30/18768.s $\mathrm{html}>$ at 31 August 2007.

Dun, Wen, Interview with Ming'an Jiang, Professor of Peking University (Beijing, 29 September 2003).

Eagles, Ian et al, Freedom of Information in New Zealand ( $1^{\text {st }}$ ed, 1992).

Elster, Jon, Deliberative Democracy $\left(1^{\text {st }} \mathrm{ed}, 1998\right)$.

The Draft of FOI Regulations 2002 (China).

Finn, Chris, 'Rethinking Commercial Confidentiality in the Decade of Competition Policy’ (2003)106 Freedom of Information Review 60-7.

FlorCruz, Jaime, China's Government Gives Rare Transparent Look at Disaster (2008) CNN <http://www.cnn.com/2008/WORLD/asiapcf/05/15/florcruz.china/> at 22 May 2008.

Foerstel, Herbert, Freedom of Information and the Right to Know: The Origins and Applications of the Freedom of Information Act $\left(1^{\mathrm{st}} \mathrm{ed}, 2000\right)$.

"FOI" Is the Prelude to Civil Society' (in Chinese) Southern Daily (Guangzhou) 15 February 2007, A02.

Ford, Peter, 'This Time, Beijing's Disaster Response Is Open, Sensitive' Christian Science Monitor (Boston) 4 February 2008, 6.

Frankel, Maurice, Freedom of Information: Some International Characteristics (2001) The Campaign of Freedom of Information <http://www.cfoi.org.uk/pdf/ams terdam.pdf $>$ at 13 November 2006.

'Freedom of Information Draft Bill', Public Administration Committee, HC 570, 3rd Report Session 1998-99, HC 570-I.

Gan, Yisheng, 'Speech by Yisheng Gan at the Teleconference on Training in FOI Regulations' (Speech delivered at Beijing, 17 May 2007). 
Gellman, Robert, 'The Foundation of United States Government Information Dissemination Policy' in Georg Aichholzer and Herbert Burket (eds), Public Sector Information in the Digital Age: Between Markets, Public Management and Citizens' Rights (2004) 123-35.

Geoffrey, Fowler and Qin, Juying, 'China Moves to Boost Transparency, But Much Is Kept Hidden' Wall Street Journal (New York), 25 April 2007, A6.

Gillis, Robert, 'Freedom of Information and Open Government in Canada' in Andrew McDonald and Greg Terrill (eds), Open Government: Freedom of Information and Privacy (1998) 143-66.

Gittings, John, The Changing Face of China: From Mao to Market $\left(1^{\text {st }}\right.$ ed, 2005).

Goldring, John, "The Foundations of the "New Administrative Law" in Australia' (1981) 40 Australian Institute of Public Administration 79-102.

Gorbachev, Mikhail, Selected Comments of Gorbachev (1 ${ }^{\text {st }}$ ed, 1987).

Grugel, Jean, Democratisation: A Critical Introduction (1 ${ }^{\text {st }}$ ed, 2002).

Guan, Si, 'Rapid Development, Broad Coverage and Various Methods: Discussion of the Use of Current Documents' (in Chinese) (2004) 2 China Archives 7-9.

Guo, Jinjin and Liu, Wei, 'Twenty Deputy Secretary-Generals in the Tielin Government Sparked Heated Discussion' (in Chinese) Chengdu Business Daily (Chengdu) 27 November 2008, 7.

Hachten, William and Scotton, James, The World News Prism: Global Information in a Satellite Age ( $\left.7^{\text {th }} \mathrm{ed}, 2006\right)$.

Han, Han, 'Transparency in Earthquake Information as a Tool for Maintaining Social Order' (in Chinese) The Economic View (Zhengzhou) 15 May 2008, A04.

Han, Jian and Wang, Junliang, The Basic Theory and Practice of Law-Based Administration in China (in Chinese) $\left(1^{\text {st }} \mathrm{ed}, 2006\right)$.

Hao, Xiang, 'SMS Messages - The Communication Potential and Development Problems of "the Fifth Medium"' (in Chinese) (2006) 1 Southeast Communication 15-16.

Hart, David, 'Entrepreneurship Policy: What It Is and Where It Came from' in David Hart (ed), The Emergence of Entrepreneurship Policy: Governance, Startups, and Growth in the U.S. Knowledge Economy (2003) 3-19. 
Hart, Thomas, 'Freedom of Information/Access to Government Information Checklist: Minimum Requirements for a Freedom of Information Act (FOIA) and Its Implementation' (EU-China Information Society Project, 2005-2009).

He, Baogang, 'Deliberative Democracy and Democratisation' (in Chinese) (2007) 4 China Institute of Theory on the Chinese People's Political Consultative Conference 34-9.

, 'The Theory and Practice of Chinese Grassroots Governance: Five Models' (2003) 4 Japanese Journal of Political Science 293-314.

He, Yong, 'The Leading Group on National Openness in Government Affairs Answered the Questions from Journalists about the Notice on Further Promoting Openness in Government Affairs' (Press Release, 27 April 2005).

'The Speech of Yong He at the Second Meeting of the Leading Group on National Openness in Government Affairs' (Speech delivered at Beijing, 29 April 2004).

, 'The Speech of Yong He at the Fourth Meeting of the Leading Group on National Openness in Government Affairs' (Speech delivered at Beijing, 25 March 2005).

, 'The Speech of Yong He at the Sixth Meeting of the Leading Group on National Openness in Government Affairs' (Speech delivered at Beijing, 31 March 2006).

, 'The Speech of Yong He at the Seventh Meeting of the Leading Group on National Openness in Government Affairs' (Speech delivered at Beijing, 21 March 2007).

, 'The Speech of Yong He at the Eighth Meeting of the Leading Group on National Openness in Government Affairs' (Speech delivered at Beijing, 24 March 2008).

$\mathrm{He}$, Zhong and $\mathrm{Pu}$, Jinli, 'The First FOI Lawsuit in Henan Province Reached out of Court Settlement' (in Chinese) Workers ' Daily (Beijing) 28 August 2008, 6.

He, Zongzhi, 'FOI Still Has a Long Way to Go' (in Chinese) $21^{\text {st }}$ Century Business Herald (Guangzhou) 8 July 2008, 8.

Heald, David, 'Varieties of Transparency' in Christopher Hood and David Heald (eds.), Transparency: The Key to Better Governance? (2006) 25-43.

Herman, Jack, 'The Urgent Need for Reform of Freedom of Information in Australia' (Speech delivered at Conference on Public Right to Know, Sydney, 21 August 2004). 
Hood, Christopher, 'A Public Management for All Seasons' (1991) 69 Public Administration 3-19.

Horsley, Jamie, 'Introduction on Open Government Information Implementation' (2006) 23 Government Information Quarterly 5-10.

, 'Toward a More Open China?' in Florini Ann (ed), The Right to Know: Transparency for an Open World (2007) 54-91.

China Adopts First Nationwide Open Government Information Regulations (2007) Freedom of Information Organisation <http://www.freedom info.org/features/20070509.htm> at 28 August 2007.

, China's Pioneering Foray into Open Government: A Tale of Two Cities (2003) Freedom of Information Organisation <http://www.freedom info.org/news/20030714.htm $>$ at 23 August 2006.

Shanghai Advances the Cause of Open Government Information in China (2004) Freedom of Information Organisation <http://www.freedom info.org/news/20040420.htm > at 23 August 2006.

Hou, Ting et al, 'On the Construction of an Online Information System for Seeking Public Opinions on Drafts of Administrative Rules' (in Chinese) (2008) $7 E$ Government 90-3.

$\mathrm{Hu}$, Angang, 'Public Exposure of Economic Losses Resulting from Corruption' (2002) 4 China \& World Economy 44-9.

$\mathrm{Hu}$, Chaohong, 'The FOI Mechanism' in Yuchuan Mo and Hongchao Lin (eds), Interpretations of the FOI Regulations in China (2008) 89-118.

$\mathrm{Hu}$, Jianmiao and Ma, Lianji, 'The Legal Foundation for Government Management and FOI' (in Chinese) (2005) 4 Legal Forum 13-20.

Hu, Jintao, 'Fully Implementing the Constitution to Provide Legal Guarantees for Building a Well-Off Society in All Aspects' (in Chinese) (Speech delivered at the $20^{\text {th }}$ Anniversary of the Adoption of the Constitution, Beijing, 4 December 2002).

, 'Hold High the Great Banner of Socialism with Chinese Characteristics and Strive for New Victories in Building a Moderately Prosperous Society in All Respects' (in Chinese) (Speech delivered at the $17^{\text {th }}$ National Congress of the CPC, Beijing, 24 October 2007).

(Beijing) 20 June 2008, 4. 
Speech delivered at the $50^{\text {th }}$ Anniversary of the National People's Congress, Beijing, 15 September 2004.

, Speech delivered at the Party School of the CPC Central Committee, Beijing, 25 June 2007.

$\mathrm{Hu}$, Yaobang, 'Comprehensively Create a New Situation in Building Socialism with Chinese Characteristics' (in Chinese) (Speech delivered at the $12^{\text {th }}$ National Congress of the CPC, Beijing, 1 September 1982).

Huang, Qingchang, 'FOI Requests Confronted Difficulties' (in Chinese) People 's Daily (Beijing) 12 November 2008, 13.

Huang, Shihong, 'Pay Attention to the Sessions of the Chinese People's Political Consultative Conference and the National People's Congress'(in Chinese) Fujian Daily (Fuzhou) 12 March 2007, 2.

Huang, Xinghang et al, 'I Am an Ungrateful and Disloyal Man' (in Chinese) People's Court Daily (Beijing) 21 February 2004, 4.

Huang, Zongliang, 'Learning Experiences and Lessons from Ruling Parties in Foreign Countries to Strengthen the Building of Governance Capabilities of the CPC' (in Chinese) (2004) 4 Journal of the Party School of Tianjin Committee of the CPC 41-9.

Hubbard, Paul, 'Accountability in the Grey Area: Employing Stiglitz to Tackle Compliance in a World of Structural Pluralism: A Comparative Study' (2004) 111 Freedom of Information Review 26-32.

, 'China's Regulations on Open Government Information: Challenges of Nationwide Policy Implementation' (2008) 1 Open Government: A Journal on Freedom of Information <http://www.opengovjournal.org/article/viewArticle/ $2651>$ at 22 July 2009.

, 'Freedom of Information and Security Intelligence: An Economic Analysis in an Australian Context' (2005) 1 Open Government: A Journal on Freedom of Information <http://www.opengovjournal.org/article/view/334/286> at 22 July 2009.

Hunt, Michael and Chapman, Richard, 'Open Government and Freedom of Information' in Richard Chapman and Michael Hunt (eds), Open Government in a Theoretical and Practical Context (2006) 1-10.

Huo, Hong, 'A Lawyer in Shenyang City Requested Government Information for the First Time' (in Chinese) Shenyang Daily (Shenyang) 28 July 2008, A02. 
Information Clearinghouse Japan, Breaking down the Walls of Secrecy: The Story of the Citizen's Movement for an Information Disclosure Law (2002) Freedom of Information Organisation <http://www.freedominfo.org/features/20020727.htm> at 26 July 2008.

Iyer, Venkat, Freedom of Information: Principles for Legislation (2000) UNPAN $<$ http://unpan1.un.org/intradoc/groups/public/documents/APCITY/UNPAN002177. pdf $>$ at 13 July 2007.

James, Simon, 'The Potential Benefits of Freedom of Information' in Richard Chapman and Michael Hunt (eds), Open Government in a Theoretical and Practical Context (2006) 27-32.

Jia, Qingjun, 'Introduction of Experience in Russia by Hongzhang Li' (in Chinese) (2004) 8 Insight China 73-5.

Jiang, Bixin and Li, Guangyu, 'Discussion of Issues Related to FOI Lawsuits' (in Chinese) (2009) 3 Political Science and Law 12-26.

Jiang, Zemin, 'Accelerate Strides toward Reform and Opening up and Modernism, Strive for Greater Victories in Building Socialism with Chinese Characteristics' (in Chinese) (Speech delivered at the $14^{\text {th }}$ National Congress of the CPC, Beijing, 12 October 1992).

, 'Build a Well-off Society in an All-Round Way and Create a New Situation in Building Socialism with Chinese Characteristics' (in Chinese) (Speech delivered at the $16^{\text {th }}$ National Congress of the CPC, Beijing, 8 November 2002).

, 'Hold High the Great Banner of Deng Xiaoping Theory for an Allround Advancement of the Cause of Building Socialism with Chinese Characteristics to the $21^{\text {st }}$ Century' (in Chinese) (Speech delivered at the $15^{\text {th }}$ National Congress of the CPC, Beijing, 12 September 1997).

, Selected Works of Zemin Jiang (Volume I) (in Chinese) (1 ${ }^{\text {st }}$ ed, 2006).

Jie, Lin and Sun, Xiangyang, 'Twenty Six Guangzhou Citizens Took the Guangzhou Labour Bureau to Court' (in Chinese) China Youth Daily (Beijing) 7 January 2008,7 .

$\mathrm{Ju}$, Lianhe and Wang, Yafan, 'Four Factors of the Operation System of Current China's Openness in Government Affairs' (in Chinese) (2005) 6 Journal of Northeast Normal University 43-7.

Kolhammar, Jens, The Challenge to Implement the Open Government Information Regulation in China (2008) China Elections <http://en.chinaelections.org/news info.asp?newsid=17891 $>$ at 2 October 2008. 
Kreisler, Harry, Interview with Manuel Castells (Berkeley, 9 May 2001).

Kubicek, Herbert, 'Third-Generation Freedom of Information in the Context of EGovernment: The Case of Bremen, Germany' in Georg Aichholzer and Herbert Burkert (eds), Public Sector Information in the Digital Age: Between Markets, Public Management and Citizens' Rights (2004) 275-86.

Lai, Haoning, A PhD Candidate at Tisunghua University Took the Shanghai Government to Court for Charging Expressway Tolls (in Chinese) (2005) People.com <http://finance.people.com.cn/GB/1037/3821518.html> at 18 May 2007.

Lai, Yulian, 'The Harbin Government Works out the Emergency Plan for Water Supply' (in Chinese) Heilongjiang Daily (Harbin) 22 November 2005, 1.

Lamble, Stephen, 'FOI as a United States' Foreign Policy Tool: A Carrot and Stick Approach' (2003) 105 Freedom of Information Review 38-43.

'Media Use of FOI Surveyed: New Zealand Puts Australia and Canada to Shame' (2004)109 Freedom of Information Review 5-9.

Computer-Assisted Reporting and Freedom of Information (D Phil Queensland University, 2002).

Lan, Ling, 'Open Government and Transparency Policy: China's Experience with SARS' (2005) 6 International Public Management Review 60-75.

Lang, Youxing, 'Deliberative Democracy and Local Experiences in China: A Case Study on the "Democratic Talkfest" in Zhejiang Province' (in Chinese) (2005) 1 Zhejiang Social Science 33-8.

Lao, Zi, Tao De Jing. See http://www.guoxue.com/zibu/zibu zhuziml/laozi.htm.

'Law-Based Administration: From Government Ruled by Law to Government under the Rule of Law' (in Chinese) Legal Daily (Beijing) 6 July 2008, 6.

Lenin, Vladimir, Lenin Collected Works (Volume 5) $\left(1^{\text {st }}\right.$ ed, 1961).

, Lenin Collected Works (Volume 10) $\left(1^{\text {st }}\right.$ ed, 1962).

, Lenin Collected Works (Volume 29) $\left(1^{\text {st }}\right.$ ed, 1961)

Lewis, Jeremy, FOIA Blog: Freedom of Information Laws and Policies (2009) Huntingdon College <http://ww1.huntingdon.edu/jlewis/FOIA/FOIAlog.htm $>$ at 19 August 2009.

Li, Daoquan and Wang, Xuqiang, 'A Shanghaiese Lodged the First FOI Lawsuit' (in Chinese) Oriental Morning Post (Shanghai) 14 June 2004, A1. 
Li, Datong, An End to Exclusivity (2007) Open Democracy <http://www.open democracy.net/node/4585> at 7 March 2009.

$\mathrm{Li}$, Donghong and Li, Junde, 'Why Is There Glass Door Effect of Sunshine Government?' (in Chinese) Henan Daily (Shijiazhuang) 22 June 2006, 12.

Li, Fan, 'The Practice of Democratic Elections in China' (in Chinese) (2005) 9 China Reform 15-21.

Li, Gang, The Legal Action against the Shanghai Government for Refusing to Disclose Information on Tuition Fees Paid for Civil Servants' Executive Master of Business Administration Training Courses (in Chinese) (2008) Public Interest Litigation <http://www.pil.org.cn/ article_view.asp?uid=964> at 10 October 2008.

Li, Guangyu, 'Parties to FOI Lawsuits' (2009) 4 E-Government 43-51.

, 'Several Intangible Areas Related to FOI' (in Chinese) People's Court Daily (Beijing) 15 August 2008, 6.

, 'Several Issues concerning the Acceptance of FOI Lawsuits (Pt 1)' (in Chinese) People's Court Daily (Beijing) 31 May 2007, 6.

Li, Hua, 'Political Publicity: Significance, Pitfalls and Inspiration' (in Chinese) (2004) 8 Nanjing Social Science 44-53.

Li, Hujun, A Tisunghua Academic Requested Information on Seismic Intensity Distribution Map (in Chinese) (2008) Caijing <http://www.caijing.com.cn/200806-13/100069541.html> at 22 October 2008.

Li, Kecheng and Wu, Yurong, 'Eight Deputy Mayors in Xinxiang Did not Exceed Personnel Quotas' (in Chinese) Oriental Morning Post (Shanghai) 3 December 2008, A20.

'Li on American Hatred' The New York Times (New York) 3 September 1896, 10.

Li, Peng, Report on the Work of the Government to the National People's Congress (Speech delivered at the First Session of the Eighth National People's Congress, Beijing, 15 March 1993).

Li, Sheng, 'The Background, Main Contents and Inventory Compilation concerning China's FOI Regulations' (in Chinese) (2008) 5 E-Government 21-6.

Li, Shuming, Three Professors at Beijing University Watched Closely on the Tolls of Beijing Airport Expressway (in Chinese) (2008) Xinhua Net $<$ http://big5.xinhuanet.com/gate/big5/news.xinhuanet.com/legal/2008-06/18/conten t_8389725.htm> at 20 October 2008. 
Li, Tieying, 'A Speech at the Spring Festival Forum Held by the Contemporary China Institute' (in Chinese) (2002) 2 Contemporary China History Studies 4-8.

$\mathrm{Li}$, Weiao and Deng, Hai, Chaotic Taxi Strike Pays off in Chongqing (in Chinese) (2008) Caijing <http://english.caijing.com.cn/2008-11-15/110028781.html> at 2 December 2008.

Li, Xiaomei and Le, Wei, 'Judicial Review of FOI Lawsuits' (in Chinese) People's Court Daily (Beijing) 10 October 2008, 6.

Li, Yajie, The Decision on Awarding Agencies for Their Excellent Work on Openness in Government Affairs Issued (in Chinese) (2007) Xinhua Net $<$ http://news.xinhuanet.com/newscenter/2007-09/03/content_6657106.htm> at 6 April 2008.

, The Decision on Nominating National Models of Openness in Government Affairs Issued (in Chinese) (2007) Xinhua Net <http://news.xinhuanet.com/ newscenter/2007-09/03/content_6657023.htm $>$ at 6 April 2008.

Li, Yanjie and Zhang, Qin, Thirty-One Provincial Governments Adopted Rules on Openness in Government Affairs (in Chinese) (2006) Xinhua Net <http://news.xin huanet.com/politics/2006-12/10/content_5463360.htm> at 19 May 2008.

Li, Yulong and Wang, Shaowei, 'Fully Implementing the Work of Openness in Government Affairs in 2007 to Support the Openning of the $17^{\text {th }}$ National Congress of the Communist Party of China' (in Chinese) Discipline Inspection Daily (Beijing) 23 March 2007, 1.

Li, Zhongchang, 'The Relationship between FOI and the Right to Know' (in Chinese) (2003) 10 News Knowledge 16-17.

Liao, Zuobin and Cheng, Xiaozhen, 'Focus on the Sessions of the Chinese People's Political Consultative Conference and the National People's Congress' (in Chinese) Information Times (Beijing) 4 March 2003, A3.

Lim, Kang Benjamin and Guo, Shipeng, China Vows Government Transparency, within Limits (2007) Reuters <http://www.reuters.com/article/idUSPEK76492200 $70424>$ at 22 September 2008.

Lin, Hongchao, 'An Overview of FOI' in Yuchuan Mo and Hongchao Lin (eds), Interpretations of China's FOI Regulations (in Chinese) (2008) 27-57.

, 'What Factors Impede FOI Lawsuits' (in Chinese) Legal Daily (Beijing) 4 December 2008, 3.

Lin, Shijue, "FOI Requests Encounter "Difficulties at the Beginning", Similar to "Action Art" (in Chinese) Procuratorial Daily 23 July 2008, 5. 
Liu, Feiyu and Wang, Conghu, Evaluating FOI from Different Perspectives (in Chinese) $\left(1^{\text {st }}\right.$ ed, 2005).

Liu, Heng, FOI Legal Systems (in Chinese) $\left(1^{\text {st }}\right.$ ed, 2004).

Liu, Hong, 'The Revision of the Archives Law Initiated' (in Chinese) Legal Daily (Beijing) 1 May 2007, 4.

Liu, Hua, 'Several Legal Issues Related to FOI' (in Chinese) (2008) 6 Political Science and Law 66-71.

Liu, Jie, The Right to Know and the FOI Act (in Chinese) ( $1^{\text {st }}$ ed, 2005).

Liu, Junning, 'China's Reform: Approaching a Dead End' (2007) 3 China Security 90-102.

Liu, Shixi and Wang, Chao, 'Citizens Challenge the Government through FOI Regulations' (in Chinese) China Youth Daily (Beijing) 6 May 2008, 7.

Liu, Shixi, 'Yue Pan: "Environmental Protection Storms" Have Not Yet Made Environmental Agencies More Powerful' (in Chinese) China Youth Daily (Beijing) 6 April 2006, 7.

, 'Disclosure of Audit Results Will Be Institutionalised and Regularly in China Which Will Not Become Storms Any More' (in Chinese) China Youth Daily (Beijing) 4 November 2004.

Liu, Shupeng, 'The Suggestions of a Cangzhou Lawyer Attracted the Attention of the State Council' (in Chinese) Yanzhao City Daily (Shijiangzhuang) 5 August 2008,5 .

Liu, Wei, 'Eighty Percent of Netizens Support the Readjustment of Public Holidays' (in Chinese) Beijing Times (Beijing) 16 November 2007, 2.

Liu, Xiang, Shuo Yuan: Jin Shen. See http://www.shuku.net/novels/classic/ shuoyuan/shuoyuan.html.

Liu, Yanxun, 'Suing in the Name of FOI Regulations' (in Chinese) (2008) $21 \mathrm{New}$ Centuries Weekly 46-9.

Lou, Zhihao, The Choice of the People (in Chinese) $\left(1^{\text {st }}\right.$ ed, 1991).

Lovelock, Peter and Ure, John, 'Assessing China's Efforts in Constructing an EGovernment' in Junhua Zhang and Martin Woesler (eds), China's Digital Dream (2002) 151-76. 
$\mathrm{Lu}$, Yanyan and Yang, Lu, 'Non-Compliance with FOI Regulations Found at the Sub-National Level' (in Chinese) Henan Business Daily (Shijiangzhuang) 12 June 2008, A10.

Luo, Changping and Feng, Jie, 'The Classification System Rectified' (in Chinese) The Beijing News (Beijing) 20 September 2005, A22-23.

Luo, Haocai, The Current Trend in Modern Administrative Law (in Chinese) ( $1^{\text {st }}$ ed, 2004).

Lv, Gensheng, 'The First FOI Request Lodged in Taiyuan City for Protecting the Access Right' (in Chinese) Taiyuan Daily (Taiyuan) 14 November 2008, 3.

Ma, Fangmin, Explanations of Major Clauses in FOI Regulations (in Chinese) (2007) The Henan Government <http://www.henan.gov.cn/ztzl/system/2008/02/29 /010059943.shtml> at 12 March 2008.

$\mathrm{Ma}$, Jun et al, 'FOI Regulations Came into Force on 1 May: Obtaining a Real Picture of FOI' (in Chinese) Youth Weekend (Beijing) 15 May 2008, A08.

Ma, Li, "Trade Secrets" Cannot Become the Excuse for Standard-Exceeding Emission' (in Chinese) The Beijing News (Beijing) 23 May 2007, A19.

$\mathrm{Ma}$, Zongjin and Shi, Peijun, 'Issues on May 12 Wenchuan Earthquake and Damage Evaluation' (in Chinese) (Press Release, 4 September 2008).

Mann, James, The China Fantasy: Why Capitalism Will Not Bring Democracy to China $\left(1^{\text {st }}\right.$ ed, 2008).

Mao, Zedong, Collected Works of Zedong Mao (Volume IV) (in Chinese) ( $2^{\text {nd }}$ ed, 1991).

1953).

Selected Works of Zedong Mao (Volume III) (in Chinese) $\left(1^{\mathrm{st}} \mathrm{ed}\right.$, , Selected Works of Zedong Mao on Journalism (in Chinese) $\left(1^{\text {st }} \mathrm{ed}\right.$, 1982).

Margetts, Helen, 'Transparency and Digital Government' in Christopher Hood and David Heald (eds), Transparency: The Key to Better Governance? (2006) 197-207.

Marshall, Alfred, Principles of Economics (first published $1890,8^{\text {th }}$ ed, 1920).

Marx, Karl and Engels, Frederick, Marx and Engels Collected Works (Volume 22) (1 ${ }^{\text {st }}$ ed, 1986).

McCombs, Maxwell and Shaw, Donald, 'The Agenda-Setting Function of Mass Media' (1972) 36 Public Opinion Quarterly 176-87. 
McCrann, Grace-Ellen, 'An Examination of the Conditions Surrounding the Passage of the 1966 US Freedom of Information Act' (2007) 1 Open Government: A Journal on Freedom of Information <http://www.opengovjournal.org/article/ viewArticle/995> at 22 July 2009.

McDonagh, Maeve, Freedom of Information in Ireland ( $1^{\text {st }}$ ed, 1998).

McLeod, Ron, 'Freedom of Information' (Paper presented at the Seminar on Freedom of Information - A Current Perspective, 21 February 2000).

Mclsaac, Barbara, The Nature and Structure of Exempting Provisions and the Use of the Concept of a Public Interest Override (2001) Access to Information Review Task Force in Canada <http://www.atirtf-geai.gc.ca/paper-nature1-e.html> at 15 April 2008.

McMillan, John, 'Twenty Years of Open Government: What Have We Learnt?' (Law and Policy Paper No 21, The Federation Press, 2002).

McQuail, Denis, McQuail's Mass Communication Theory ( $\left.5^{\text {th }} \mathrm{ed}, 2005\right)$.

Meijer, Jacob Albert, 'Risk Maps on the Internet: Transparency and the Management of Risks' (2005) 10 Information Polity 105-13.

Mendel, Toby, Freedom of information: A Comparative Legal Survey $\left(2^{\text {nd }}\right.$ ed, 2008).

at 9 August 2008).

, 'Corruption, Access to Information and Human Development' (Draft

Missen, Alan, 'Freedom of Information - The Australian Experience' (2002) 100 Freedom of Information Review 42-6.

Mo, Yuchuan, 'From Sunshine Government to Government under the Rule of Law' in Yuchuan Mo and Hongchao Lin (eds), Interpretations of China's FOI Regulations (in Chinese) (2008) 1-26.

, 'How Can Power Be Exercised Well in a Transparent Way' (in Chinese) Legal Daily (Beijing) 13 February 2008, 3.

Neuman, Laura and Calland, Richard, 'Making the Law Work: The Challenges of Implementation' in Ann Florini (ed), The Right to Know: Transparency for an Open World (2007) 179-213.

New Regulation Approved to Boost Government Transparency (in Chinese) (2007) The Central Government <http://english.gov.cn/2007-01/17/content_499497.htm> at 12 March 2007. 
Niu, Longyun, 'Scrutinisation of the Constitutional Review System following the Sun Incident' (in Chinese) (2003) 22 Outlook Weekly 50-2.

Niu, Zhonghai, 'The Latest Development of the Case regarding Male and Female Different Retirement Age in Pingdingshan: The Review of the Constitution Recommended' (in Chinese) Dahe Daily (Zhengzhou) 24 July 2006, A09.

No Pork Meat Disease Outbreak in Beijing: Health Official (2007) People Net $<\mathrm{http}: / /$ english.peopledaily.com.cn/200701/14/eng20070114_341068.html> at 2 August 2008.

Non-Disclosure Problems for Several Local Governments (in Chinese) (2008) Xinhua Net <http://news.xinhuanet.com/politics/2008-07/30/content_8851290.h tm> at 10 March 2009.

North, Douglass, Institutions, Institutional Change and Economic Performance $\left(1^{\text {st }}\right.$ ed. 1990).

Oslo Governance Centre, UNDP and the Right to Information (2006) Freedom of Information Organisation <http://www.freedominfo.org/documents/Seminar_Re port_-_UNDP_and_the_Right_to_Information.pdf $>$ at 5 September 2008.

Ou, Yangwu and Lv, Yanbin, 'FOI System and Legislation of FOI in China' (in Chinese) (2006) 6 Journal of Guangxi Administrative Cadre Institute of Politics and Law 14-19.

Ou, Yangwu, Speech delivered at Seminar on the FOI Regulations, Beijing, 17 March 2007. See http://www.hongfan.org.cn/file/upload/2007/03/17/12150978 25.pdf.

Pasquier, Martial and Vileneuve, Jean-Patrick, 'The Totally Transparent Administration: Radical Change or Bureaucratic Illusion?' (Paper presented at Conference on Public Managers under Pressure between Politics, Professionalism and Civil Society, Milan, 6 September 2006).

Paterson, Moira, 'Transparency in the Modern State Happy Birthday FOI! or Commiserations?' (2004) 29 Alterative Law Journal 10-14.

, Freedom of Information and Privacy in Australia $\left(1^{\text {st }}\right.$ ed, 2005).

Pearlman, Mitchell, The Importance of Freedom of Information at the Sub-National Level (2008) State of Connecticut <http://www.state.ct.us/FOI/Articles/SunNational_Artic.htm> at 3 October 2008.

Peerenboom, Randall, China Modernises: Threats to the West or Model for the Rest? ( ${ }^{\text {st }}$ ed, 2007). 

, China's Long March toward Rule of Law ( $1^{\text {st }}$ ed, 2002).

Peterson, Warren and Noel, Gist, 'Rumour and Public Opinion' (1951) 57 The American Journal of Sociology 159-67.

Piotrowski, Suzanne et al, 'Key Issues for Implementation of the Chinese Open Government Information Regulations' (2009) 69 (Supplement 1) Public Administration Review 129-35.

Potter, Pitman, 'The Chinese Legal System: Continuing Commitment to the Primacy of State Power' (1999) 159 The China Quarterly 673-83.

Public Interest Litigation, Inappropriateness of the Rejection of an FOI Lawsuit by the Shanghai Luwan District Court (in Chinese) (2005) <http://www.pil.org.cn/ article_view.asp?uid=175> at 5 September 2007.

Qiao, $\mathrm{Mu}$, 'The Communication Effect and Political Impact of SMS Messages' (in Chinese) (2008) 4 Contemporary Communications 76-7.

Qin, Hai, Speech delivered at Seminar on the FOI Regulations, Beijing, 17 March 2007. See http://www.hongfan.org.cn/file/upload/2007/03/17/1215097825.pdf.

Qin, Xudong and Chen, Zhongxiaolu, 'Slowly Move toward Sunshine Government' (in Chinese) (2008) 9 Caijing 132-38.

Qin, Xudong and Chen, Zhongxiaolu, Citizens Applied for Government Information to Promote 'Sunshine Government' (in Chinese) (2008) Caijing $<$ http://www.caijing.com.cn/20080504/59254.shtml> at 17 May 2008.

, An FOI Lawsuit Was Tried with the Anhui Government Being Sued (in Chinese) (2008) Caijing <http://www.caijing.com.cn/2008-10-09/110018705.html> at 10 October 2008.

, Revision of the Law on the Protection of State Secrets Accelerated (in Chinese) (2009) Caijing <http://www.caijing.com.cn/2009-04-02/110132511.html> at 11 April 2009.

Qinghong Zeng Stresses the Comprehensive Recognition of the Significance of the Passage of the Civil Servant Law (in Chinese) (2005) The Central Government $<\mathrm{http} / / /$ www.gov.cn/zfjs/2005-09/22/content_68644.htm> at 9 February 2008.

Rare Snow Storms in China's 10 Provinces and Has Lasted for Half a Month with 32.87 Million People Being Caught up (in Chinese) (2008) China News $<$ http://www.chinanews.com.cn/gn/news/2008/01-26/1146727.shtml> at 15 April 2008. 
Ren, Guizhan, The Mine Water Leakage Accident in Nandan County and Its Lessons (in Chinese) (2002) People Net <http://www.people.com.cn/GB/shehui/21 2/6048/6320/20020109/644953.html> at 15 April 2008.

Report of the Special Rapporteur, Promotion and Protection of the Right to Freedom of Opinion and Expression, E/CN.4/1998/40, 28 January 1998.

Roberts, Alasdair, 'Structural Pluralism and the Right to Information' (2001) 51 University of Toronto Law Journal 243-71.

2006).

, Blacked out: Government Secrecy in the Information Age $\left(1^{\text {st }}\right.$ ed,

, 'Dashed Expectations: Governmental Adaptation to Transparency Rules' in Christopher Hood and David Heald (eds), Transparency: The Key to Better Governance? (2006) 107-25.

Freedom of Information: From Millions to Billions (2008) Sunshine Week <http://www.sunshineweek.org/sunshineweek/roberts08> at 2 October 2008.

'Future Challenges for the RTI Movement' (Speech delivered at the $5^{\text {th }}$ International Conference of Information Commissioners, Wellington, 26-29 November 2007).

Limited Access: Assessing the Health of Canada's Freedom of Information Laws (1998) Canadian Newspaper Association <http://www.cnaacj.ca/Client/CNA/cna.nsf/object/LimitedAccess/\$file/limitedaccess.pdf> at 17 November 2006.

, 'New Strategies for Enforcement of the Access to Information Act' (2002) 27 Queen's Law Journal 647-82.

Rosenbaum, Martin, 'Open to Question - Journalism and Freedom of Information' (2004) 9 Communications Law 126-35.

Schartum, Wiese Dag, 'Information Access Legislation for the Future? Possibilities according to a Norwegian Experience' in Georg Aichholzer and Herbert Burkert (eds), Public Sector Information in the Digital Age: Between Markets, Public Management and Citizens' Rights (2004) 69-90.

Schedler, Kuno and Proeller, Isabella, 'The New Public Management: A Perspective from Mainland Europe' in Kathleen McLaughlin and Stephen Osborne (eds), New Public Management: Current Trends and Future Prospects (2001) 16380 .

Sebina, Peter, Freedom of Information and Records Management: A Learning Curve for Botswana (D Phil Thesis, University College London, 2006). 
Shang, Yuguang, 'Discussion of the System of Administrative Openness' (in Chinese) (2005) 24 The Epochal Tide 48-9.

Sheng, Dalin, 'It Is Encouraging to Find That the Government Has Not Covered up Sensitive Events' (in Chinese) Qilu Evening (Jinan) 19 November 2008, A2.

Sheng, Ruowei, Interview with the Ministry of Personnel (Beijing, 12 August 2003).

Shi, Weimin, 'Many a Little Makes a Mickle - An Overview of the Building of Grassroots Democracy in China from 2000 to 2005' (in Chinese) (2005) 9 China Reform 15-21.

Snell, Rick and Sebina, Peter, 'Information Flows: The Real Art of Information Management and Freedom of Information' (2007) 35 Archives and Manuscripts 54-81.

Snell, Rick and Xiao, Weibing, 'Freedom of Information Returns to China' (2007)10 Public Administration Today, 44-7.

Snell, Rick, 'Administrative Compliance - Evaluating the Effectiveness of Freedom of Information' (2001) 93 Freedom of Information Review 26-32.

, 'Administrative Compliance and Freedom of Information in Three Jurisdictions: Australia, Canada and New Zealand' (Paper presented at Conference on Freedom of Information: One Year on, Dublin, 23 April 1999).

, 'Constructing a Field: Commonwealth FOI Studies' (Speech delivered at Comparative Administrative Law Lecture, Hobart, 7 August 2009).

$5-9$.

, 'Failing the Information Game' (2007) 10 Public Administration Today

, 'FOI and the Delivery of Diminishing Returns, or How Spin-Doctors and Journalists Have Mistreated a Volatile Reform' (2002) 3 The Drawing Board: An Australian Review of Public Affairs 187-207.

, 'Freedom of Information Practices' (2006) 13 Agenda 291-307.

, 'The Kiwi Paradox - A Comparison of Freedom of Information in Australia and New Zealand' (2000) 28 Federal Law Review 575-616.

, 'Opening up the Mindset Is Key to Change' (2008) The Canberra Times 4 November 2008, 10-11. 
, 'Releasing the Potential of FOI - Making the Transition from FOI Version 1.0 to FOI Version $2.0^{\prime}$ (Speech delivered at the University of Tasmania Law School Staff Seminar, Hobart, 5 November 2008).

, 'Using Comparative Studies to Improve Freedom of Information Analysis: Insights from Australia, Canada and New Zealand' (Paper presented at Sixth National and Second International Congress on the Right to Information, Mexico, 8-11 November 2005).

Song, Bing and Liu, Wen, 'Gradual Perfection of the Spokesperson System in China' (in Chinese) People's Daily Overseas Edition (Beijing) 7 November 2008, 1.

Stiglitz, Joseph, 'On Liberty, the Right to Know, and Public Discourse: The Role of Transparency in Public Life' (Speech delivered at Oxford Amnesty Lecture, Oxford, 27 January 1999).

, 'Transparency in Government' in the World Bank (ed), The Right to Tell: The Role of Mass Media in Economic Development (2002) 27-44.

Streets, Susan, Administrative Law ( $2^{\text {nd }}$ ed, 2000).

Stubbs, Rhys, 'FOI and Democracy in Australia and Beyond' (2008) 4 Australian Journal of Political Science 667-84.

Su, Lin et al, 'Journalists' Real Experiences of "Non-Disclosure Information"' (in Chinese) Southern Weekend (Guangzhou) 10 July 2008, A05.

$\mathrm{Su}$, Yongtong and Cai, Muzi, 'Implementation of FOI Regulations Challenged at the Beginning' (in Chinese) Southern Weekend (Guangzhou) 10 July 2008, A05.

Sun, Jibin and Ding, Jinfeng, 'Public Libraries Prepared Little for Providing Access to Government Information' (in Chinese) Legal Daily Weekly (Beijing) 25 August 2008.

Sun, Xuyang, 'The First FOI Case Suspended in Binzhou' (in Chinese) The Beijing News (Beijing) 13 May 2008, A21.

Suominen, Kati, 'Access to Information in Latin America and the Caribbean' (2003) 2 Comparative Media Law Journal 30-68.

Sutton, Graham and Holsen, Sarah, 'China Progresses Information Access and Data Protection Laws' (2006) 2 Open Government: A Journal on Freedom of Information <http://www.opengovjournal.org/article/view/621/482> at 22 July 2009. 
Tankersley, Michael, 'How the Electronic Freedom of Information Act Amendments of 1996 Update Public Access for the Information Age' (1998) 50 Administrative Law Review 421-57.

Tasmanian Department of Justice, Strengthening Trust in Government ... Everyone 's Right to Know Directions Paper (2009).

Taylor, John, 'Freedom with Information: Electronic Government, Information Intensity and Challenges to Citizenship' in Richard Chapman and Michael Hunt (eds), Open Government in a Theoretical and Practical Context (2006) 125-38.

, 'Governance and Electronic Innovation: Whither the Information Polity?' (1998) 1 Information Communication \& Society 144-62.

'Informatisation as X-ray: What Is Public Administration for the Information Age?' in I.Th.M. Snellen and W.B.H.J.van de Donk (eds), Public Administration in an Information Age: A Handbook (1998) 21-32.

, 'Rediscovering the Grand Narratives of the Information Polity: Reflections on the Achievement and Potential of the EGPA Study Group on ICT in Public Administration' (2007) 12 Information Polity 213-17.

, 'The Information Polity' in Willam Dutton (ed), Society on the Line: Information Politics in the Digital Age (1999) 197-98.

Terrill, Greg, 'Individualism and Freedom of Information Legislation' (2000) 87 Freedom of Information Review 30-2.

, 'The Rise and Decline of Freedom of Information in Australia' in

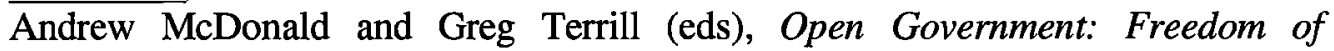
Information and Privacy (1998) 89-115.

Secrecy and Openness: The Federal Government from Menzies to Whitlam and beyond ( $1^{\text {st }}$ ed, 2000).

The Access to Information Review Task Force, Access to Information: Making It Work for Canadians (2002) <http://www.atirtf-geai.gc.ca/accessReport-e.pdf> at 28 August 2009.

The 11 Five-Year Plan for National Economy and Social Development (in Chinese) (2006) Xinhua Net <http://news.xinhuanet.com/misc/2006-03/16/content_430 9517_20.htm> at 7 May 2008.

The Attorney-General's Department, Commonwealth Copyright (2006) $<$ http://www.ag.gov.au/www/agd/agd.nsf/Page/Copyright_CommonwealthCopyrig htAdministration_Commonwealthcopyright> at 4 May 2008. 
The Australian Senate Standing Committee on Constitutional and Legal Affairs, Parliament of Commonwealth, Freedom of Information (1979).

The Centre for International Communications Studies of Tsinghua University, 'The Ruling Capability of the Chinese Government and the Institutionalisation of Spokesperson Systems' (in Chinese) (2005) 8 Today's Mass Media 7-9.

The Chinese Government Signed the United Nations Convention against Corruption and Put up Four Recommendations (in Chinese) (2003) Xinhua Net $<$ http://news.xinhuanet. com/world/2003-12/11/content_1224815.htm> at 5 April 2008.

The Commonwealth Human Rights Initiative, Open Sesame: Looking for the Right to Information in the Commonwealth (2003)<http://www.humanrightsinitiative.org/ publications/chogm/chogm_2003/chogm\%202003\%20report.pdf> at 25 May 2007.

The Commonwealth Ombudsman, Annual Report 1996-1997.

The CPC Central Committee, Communique of the Fifth Plenary Session of the $15^{\text {th }}$ CPC Central Committee (2000).

Communique of the Second Plenary Session of the $17^{\text {th }}$ CPC Central Committee (2008).

The Department of Premier and Cabinet in New South Wales, Open Government Information: FOI Reform in New South Wales Companion Guide to the Bills (2009).

The Development of Government Informatisation in China (in Chinese) (2003) China Net <http://www.china.com.cn/chinese/zhuanti/283258.htm> at 19 May 2008.

The EU Commission, Green Paper on Public Sector Information Com (1998).

The FOI Independent Review Panel, Enhanced Open and Accountable Government: Review of the Freedom of Information Act 1992, Discussion Paper (2009).

Information Act (2008).

, The Right to Information: Reviewing Queensland's Freedom of

The General Office of the Central Commission for Discipline Inspection, Openness in Government Affairs (in Chinese) (1 ${ }^{\text {st }}$ ed, 2004). 
The General Office of the Inner-Mongolia Autonomous Region, The General Office's FOI Guide (in Chinese) (2008) <http://zfxxgk.nmg.gov.cn/default/modu les/gkzn/znmx.jsp?columnid=iroot19001\&articleid=15160> at 10 October 2008.

The General Office of the State Council, Freedom of Information Regulations 2007 Annual Report 2008.

Preparation for Implementation of FOI Regulations in Sichuan Was Tremendously Effective (in Chinese) (2008) The Central Government $<$ http://www.gov.cn/zfjs/2007-09/18/content_753799.htm> at 19 March 2009.

The Hon. Sir Mason. Anthony, 'The Relationship between Freedom of Expression and Freedom of Information' in Jack Beatson \& Yvonne Cripps (eds), Freedom of Expression and Freedom of Information (2000) 225-348.

The Hunan Government, Freedom of Information Regulations 2007 Annual Report 2008 .

The Indicator System for Assessing the Performance of Government Websites in 2008 (in Chinese) (2008) The Ministry of Industry and Information Technology <http://xxhs.miit.gov.cn/n11293472/n11295327/n11297217/11746784.html> at 17 May 2009.

'The Institutional Framework of the Personnel System Has Been Formed on a Preliminary Basis' (in Chinese) (2006) 32 Information for Deciders 7.

The Journalist in the China Legislative Information Network System, Interview with a Leader in the State Council Legislative Affairs Office (Beijing, 25 April 2007).

The Legislative Affairs Office of the Guangdong Province, A Series of Administrative Reconsideration Cases Solved Successfully in Shenzhen (in Chinese) (2006) China Legislative Information Network System <http://www.china law.gov.cn/jsp/contentpub/browser/contentpro.jsp?contentid $=\mathrm{co} 2381312326>$ at 7 June 2007.

The Legislative Plan of the $11^{\text {th }}$ Standing Committee of the National People's Congress (in Chinese) (2008) The National People's Congress <http://www.npc. gov.cn/npc/xinwen/syxw/2008-10/29/content_1455985.htm> at 31 October 2008.

The Legislative Plan of the $10^{\text {th }}$ Standing Committee of the National People's Congress (in Chinese) (2003) The National People's Congress < http://www.npc. gov.cn/npc/xinwen/rdyw/wj/2004-02/23/content_328577.htm> at 31 May 2008. 
The M8.0 Earthquake Intensity Distribution Map in Wenchuan (in Chinese) (2008) China Earthquake Administration <http://www.cea.gov.cn/manage/html/8a858788 1632fa5c0116674a018300cf/_content/08_09/01/1220238314350.html> at 22 October 2008.

The Ministry of Civil Affairs, The Main Achievements in Villagers' Autonomy (in Chinese)<http://www1.mca.gov.cn/artical/content/WCM_YWJS/20031224145129. htm>at 2 April 2008.

The National Corruption Prevention Bureau Established: Speech by the First Head Ma Wen (in Chinese) (2007) China News <http://www.chinanews.com.cn/gn/news/ 2007/09-13/1025663.shtml> at 13 September 2007.

The National Corruption Prevention Bureau, Departments and Responsibilities of the National Corruption Prevention Bureau (in Chinese) (2007) <http://yfj.mos. gov.cn/yfj/news.jsp?mid=20071109026298> at 5 February 2008.

The National Development and Reform Commission, Public Notice on Openly Soliciting Comments on 'Opinions about Deepening China's Healthcare Reform [Draft for Input]' (in Chinese) (2008) <http://shs.ndrc.gov.cn/yg/qianyan/t2008 0401_202368.htm>at 15 December 2008.

The National Development and Reform Commission and other Authorities Publicised the Draft Scheme on Fuel Taxation and Reform of the Refined Oil Pricing Mechanism to Seek Public Comments (in Chinese) (2008) $<$ http://www.ndrc.gov.cn/xwfb/t20081205_250290.htm>at 8 December 2008.

The New Zealand Committee on Official Information, Towards Open Government: General Report (1980).

The Open Society Justice Initiative, Claude et al $v$ Chile (2007) <http://www.justiceinitative.org/db/resource2?res_id=102628> at 1 March 2009.

Transparency \& Silence: A Survey of Access to Information Laws and Practices in 14 Countries (2006) Open Society Institute \& Soros Foundations Network<http://www.soros.org/resources/articles_publications/publications/transpa rency_20060928/transparency_20060928.pdf> at 12 November 2006.

'The Plan for Restructuring the State Council' (in Chinese) People's Daily (Beijing) 16 March 2008, 5.

The Report on the Review Results of the Proposals from the Deputies of the Second Plenary Session of the $10^{\text {th }}$ National People's Congress by the Internal and Judicial Affairs Committee of the National People's Congress 27 October 2004.

The Retrospective of the 25-Year Spokesperson System (2008) Spokesmen $<$ http://www.51fayan.com/fyrzd25/> at 8 December 2008. 
The Shanghai Government, Freedom of Information Rules 2004 Annual Report 2008 .

The Shanghai Legislative Affairs Office and the Shanghai Institute for Administrative Law Studies, 'Analysis of Discrimination between Access Requests and Petitions' (in Chinese) (2008) 5 The Brief Report on the Shanghai Government Rule of Law.

, 'The Methods of Replying to Access Requests' (in Chinese) (2008) 16 The Brief Report on the Shanghai Government Rule of Law.

, 'Work Review for 2006 and Work Outline for 2007 of the Shanghai Legislative Affairs Office' (in Chinese) (2007) 4 The Brief Report on the Shanghai Government Rule of Law.

The Shanghai Science and Technology Commission, Freedom of Information Rules 2004 Annual Report 2005.

'The Shijiangzhuang Government Apologised for the Sanlu Milk Power Scandal' (in Chinese) Nanjing Daily (Nanjing) 1 October 2008, A01.

The State Council Informatisation Office, Informatisation Development Report in China (in Chinese) (2006) E-Gov Net <http://www.e-gov.org.cn/ziliao $\mathrm{ku} / \mathrm{news} 003 / 200606 / 28025 . \mathrm{html}>$ at 22 June 2007.

The State Council Information Office, The White Paper on China's Efforts and Achievements in Promoting the Rule of Law (Beijing, 28 February 2008). 2007, Beijing). The White Paper on China's Political Party System (15 November The White Paper on the Building of Political Democracy in China (19 October 2005, Beijing).

The Tonghai Earthquake Was Declassified after 30 Years' (in Chinese) Digest (Shanghai) 16 January 2000, 3.

The Trial of the First FOI Case in Wuhan City Was Completed with the Judgment of the Labor Bureau Violating Wuhan FOI Interim Rules (in Chinese) (2004) The Rule of Law in Qiantan <http://www.qtfz.gov.cn:8080/show.jsp?id=3303> at 7 May 2008.

The UK Advisory Panel on Public Sector Information, Public Sector Information Policy in Australia (2006)<http://www.appsi.gov.uk/reports/policy-australia.pdf> at 5 January 2008. 
The US National Commission Libraries and Information Science, The Comprehensive Assessment of Public Information Dissemination (2001) $<\mathrm{http}: / /$ www.nclis.gov/govt/assss/assess.execsum.pdf> at 27 March 2008.

The World Bank, Definition of E-Government <http://web.worldbank.org/WBS ITE/EXTERNAL/TOPICS/EXTINFORMATIONANDCOMMUNICATIONAND TECHNOLOGIES/EXTEGOVERNMENT/0,,contentMDK:20507153 menuPK:70 2592 pagePK:148956 piPK:216618 theSitePK:702586,00.html> at 14 September 2009.

There Were 72 Killed in Train Collision in Shandong (in Chinese) (2007) 163.com <http://news.163.com/08/0503/00/4AVRQBG40001124J.html> at 3 May 2008.

Thirty-Year Reform of the Cadre of Personnel System Overviewed by the Ministry of Personnel with Three Phases (in Chinese) (2008) China Net <http://www.china. com.cn/news/txt/2008-04/11/content_14937807.htm> at 14 April 2008.

"Three Kinds of Openness" Record the Historical Development of Democracy and Legal Systems' China Discipline Inspection Daily (in Chinese) (Beijing) 3 September 2007, 01 .

Tian, Doudou, 'The Government Lost Its FOI Lawsuit for the First Time' (in Chinese) People's Daily (Beijing) 10 October 2008, 10.

Tian, Shuangyue and Xin, Hua, 'Public Hearings will be Held for the Guangdong Oil Refinery Project' Southern Metropolis Daily (in Chinese) (Guangzhou) 11 March 2008, A09.

'Upright Jinhua Li Left the Office with Audit Storms still Going on' (in Chinese) Guangzhou Daily (Guangzhou) 18 March 2008, A4.

Van de Donk, W.B.H.J. and Snellen, Th.M. Ignace, 'Towards a Theory of Public Administration in an Information Age?' in I.Th.M. Snellen and W.B.H.J.van de Donk (eds), Public Administration in an Information Age: A Handbook (1998) 320.

Voices against Discrimination: An Update of Recent Cases and Developments (2006) China Law and Governance Review <http://www.chinareview.info/pages/ case.htm> at 24 April 2008.

Volman, Yvo, 'Exploitation of Public Sector Information in the Context of the eEurope Action Plan' in Georg Aichholzer and Herbert Burkert (eds), Public Sector Information in the Digital Age: Between Markets, Public Management and Citizens' Rights (2004) 93-107.

Wang, Chen, 'Present a Real China to the World in a More Transparent Way' (in Chinese) (Press Conference, 30 December 2008). 
Wang, Dianxue, 'Lawyer's Request on Airport Construction Fees Answered' (in Chinese) The Beijing News (Beijing) 17 July 2008, A23.

Wang, Junxiu, 'Sixty-Eight Villagers in Yuyao City of Zhejiang Province Won Their FOI Lawsuit' (in Chinese) China Youth Daily (Beijing) 10 October 2008, 6.

, 'A Lawyer Discussed Various Strange Phenomena regarding FOI' (in Chinese) China Youth Daily (Beijing) 10 May 2008, 3.

Wang, Weijian and Yu, Jiming, 'Are Government Agencies Getting Used to FOI?' (in Chinese) People's Daily (Beijing) 8 May 2008, 10.

Wang, Xiaobo, 'The First FOI Request for Government Financial Accounts in Northeast China Submitted' (in Chinese) Commercial Times (Shenyang) 25 October 2008, A03.

Wang, Yijun, 'The Breakthrough of Legislating on FOI after a Decade' (in Chinese) China Youth Daily (Beijing) 25 April 2007, 3.

Weiss, Peter, 'Borders in Cyberspace: Conflicting Public Sector Information Policies and Their Economic Impacts' in Georg Aichholzer and Herbert Burket (eds), Public Sector Information in the Digital Age: Between Markets, Public Management and Citizens' Rights (2004) 137-59.

Wen, Jiabao, 'Our Historical Tasks at the Primary Stage of Socialism and Several Issues concerning China's Foreign Policy' People's Daily (in Chinese) (Beijing) 27 February 2007, 2.

, 'Jiabao Wen Meets with UN Secretary-General Ban Ki-moon in the Quake-Hit Area' (Press Release, 24 May 2008).

, 'Our Historical Tasks at the Primary Stage of Socialism and Several Issues concerning China's Foreign Policy' (in Chinese) People's Daily (Beijing) 27 February 2007, 2.

, 'Pushing forward Administration by Law in an All-Round Way to Build a Government under the Rule of Law' (in Chinese) (Speech delivered at the National Picturephone Conference on the Work of Law-Based Administration, Beijing, 28 June 2004).

'Report on the Work of the Government to the National People's Congress' (Speech delivered at the First Session of the $11^{\text {th }}$ National People's Congress, Beijing, 5 March 2008).

, 'Report on the Work of the Government to the National People's Congress' (Speech delivered at the Second Session of the $10^{\text {th }}$ National People's Congress, Beijing, 16 March 2004). 
, 'Report on the Work of the Government to the National People's Congress' (Speech delivered at the Second Session of the $11^{\text {th }}$ National People's Congress, Beijing, 5 March 2009).

, 'Seriously Adhere to the Spirits of the $17^{\text {th }}$ National Congress of the CPC to Promote Vigorously the Work of Incorruptibility Construction and AntiCorruption' (in Chinese) (2008) 9 Qiushi 3-8.

Wen, Weipo, Chinese Scholars Hail Government Information Transparency Regulations (2008) China Elections <http://en.chinaelections.org/newsinfo.asp? newsid $=17678>$ at 2 October 2008.

Whitlam, Gough, 'It Is Time for Leadership' (Speech delivered at the Blacktown Civic Centre, Sydney, 13 November 1972).

World Trade Organisation, Protocol on the Accession of the People's Republic of China, (WT/L/432) 23 November 2001, Part I, C (1).

Wu, Jielin, 'Issues Related to FOI Lawsuits' (in Chinese) (2009) 4 E-Government $39-42$.

Wu, Jinlian, 'Which Path of Industrialisation Should China Take?' (in Chinese) (2006) 8 Management World 1-7.

$\mathrm{Wu}$, Weizhong and $\mathrm{Li}$, Xiaohua, 'Weak Supervision of the Short Message Communication' (in Chinese) (2006) 12 Journal of Harbin University 85-8.

Wu, Yanxia, 'A Cangzhou Lawyer Complained to Several State Agencies about the Failure to Disclose Information' (in Chinese) Yanzhao City Daily (Hebei) 6 May 2008,5 .

$\mathrm{Xi}$, Fengyu, '12-Year Consideration of Revising the Law on the Protection of State Secrets' (in Chinese) Legal Daily (Beijing) 22 July 2008, 4.

Xia, Lixia et al, 'Let us Put a Question on Openness in Government Affairs: Are FOI Offices Transparent Enough?' (in Chinese) Xin'an Evening (Hefei) 20 October 2008, A3.

Xia, Yong et al, The Development Report of Rule of Law in China (in Chinese) ( $1^{\text {st }}$ ed, 2006).

Xiao, Wei, 'Ensure Smooth Enforcement of FOI Regulations' (in Chinese) Discipline Inspection Daily (Beijing) 25 March 2008, 01.

Xie, Yongqiang, 'Villagers Filed Two Lawsuits against the Township Government' (in Chinese) Huashang Newspaper (China) 16 October 2008, A14. 
Xin, Chunying and Feng, Jun, WTO and China's Administrative Law Reforms (in Chinese) $\left(1^{\text {st }}\right.$ ed, 2005).

$\mathrm{Xu}$, Xuejiang, 'Death Toll of the Tangshan Earthquake Is More Than 240,000' (in Chinese) People's Daily (Beijing) 23 November 1979.

Xue, Gangling, Discovering the Roadmap for the Rule of Administrative Law: Combined Works of Professor Gangling Xue (in Chinese) ( $\left.1^{\text {st }} \mathrm{ed}, 2006\right)$.

Yan, Jian, Make Democracy Benefit China: Dialogue with Professor Keping Yu (in Chinese) ( $\left.1^{\text {st }} \mathrm{ed}, 2009\right)$.

Yan, Hai, Theory and Practice in Government Information Publicity (in Chinese) $\left(1^{\text {st }}\right.$ ed, 2008).

Yan, Wu, 'The "Glass Door" Effect Need to be Broken by FOI' (in Chinese) People's Daily (Beijing) 9 May 2008, 11.

Yang, Lei, A Citizen Requested Government Information from 10 Agencies and Achieved Success with the Support of the Wuhan Legislative Affairs Office (in Chinese) (2005) The Wuhan Legislative Affairs Office <http://www.whfzb.gov.cn/ Article,868.html > at 21 October 2008.

Yang, Xueshan, 'Subsidiary Report on Learning FOI Regulations' (Speech delivered at Conference on Learning FOI Regulations, Beijing, 19 May 2007).

Speech delivered at the Press Conference on the Seventh Assessment of the Performance of China's Government Websites, Beijing, 11 January 2009.

Ye, Doudou, Openness in Law-Making Activity Is Underway (in Chinese) (2008) Caijing <http://www.caijing.com.cn/2008-09-03/110009953.html> at 3 October 2008.

Yi, Fei, Don't Misunderstand Deng's Warning on 'Saying Less and Doing More' (in Chinese) (2007) Xinhua Net <http://news.xinhuanet.com/comments/200702/09/content_5712689.htm> at 23 March 2009.

Yin, Chi Sim, China's Handling of Quake News 'Novel' (2008) The Straits Times $<$ http://www.straitstimes.com/Free/Story/STIStory_238121.html> at 17 May 2008.

Yin, Yong and Ding, Yong, 'On Legal Issues of FOI Lawsuits' (in Chinese) (2007) 1 Shanghai Journal of Law 40-3.

Yin, Yong, 'New Thoughts on Trying FOI Cases' (in Chinese) (2007) 5 Shanghai Journal of Law 51-2. 
Ying, Songnian, 'Overview and Expectations of China's Administrative Law' (in Chinese) (2008) 2 The Rule of Law Forum 1-8.

, 'Overview and Expectations of China's Administrative Law' (Speech delivered at Zhongshan University, Zhongshan, 6 January 2006).

, 'The Establishment of China's Administrative Law and the Problems Encountered' (in Chinese) (2001) 1 Journal of Jianghai Academia 60-4.

$\mathrm{Yu}$, Guoming, 'Guaranteeing the People's Right to Know Is the Fundamental Principle for Building the State's Information Security System'(in Chinese) (2003) 6 Practical Journalism 27-8.

Yu, Keping, 'Democracy Is the Lifeblood of the People's Republic of China' (in Chinese) (2007) 22 People Forum 6-8.

, 'Emancipation of Mind and Political Progress' (in Chinese) Beijing Daily (Beijing) 17 September 2007, 18.

Yu, Loong Au, 'Alter-Globo in Hong Kong' (2006) 42 New Left Review 117-30.

Yuan, Chang, 'What Effects of the Implementation of FOI Regulations in Haidian District?' (in Chinese) China Business News (Shanghai) 11 June 2008, A06.

Yuan, Shuang and Jiang, Yun, The Hangzhou Subway Collapse: The Party Secretary Calls for Eight Requirements (in Chinese) (2008) China News $<$ http://www.chinanews.com.cn/gn/news/2008/11-16/1451030.shtml> at 3 December 2008.

Yun, Guoqiang and Lv, Pin, The Relationship between the Media and the Government: Taking the Example of the SARS Incident (in Chinese) (2003) $21^{\text {st }}$ Century <http://www.cuhk.edu.hk/ics/21c/supplem/essay/0304069.htm>at 21 April 2008.

Van Dijk, Jan, The Network Society: Social Aspects of New Media $\left(2^{\text {nd }}\right.$ ed, 2006).

Vaughn, Robert, 'Introduction' in Robert Vaughn (ed) Freedom of Information (2000).

Vleugels, Roger, Overview of FOIA Countries Worldwide - February 12006 (2006) State Watch <http://www.statewatch.org/news/2006/feb/foia-feb-2006.pdf> at 3 October 2008. 
Zeng, Xiaodong, The General Administration of Quality Supervision, Inspection and Quarantine Was Asked to Disclose the Investigation Report on the Quality of the Mills Produced by a Top Company in Zhengzhou (in Chinese) (2008) China Radio <http://www.cnr.cn/news/200810/t20081017_505126016.html> at 18 November 2008.

Zhang, Hua and Song, Shupei, 'The First FOI Case in Zhengzhou after Implementation of FOI Regulations' (in Chinese) Zhengzhou Evening (Zhengzhou) 7 August 2008, A12.

Zhang, Jingyong et al, The 'Sunshine Project' Benefits the Masses: China Actively Promotes Openness in the Process of Administrative Affairs (in Chinese) (2003) Xinhua Net <http://news.xinhuanet.com/newscenter/2003-12/30/content_12543 92.htm > at 10 February 2008.

Zhang, Mingiie, Open Government: Research on FOI Laws (in Chinese) ( $1^{\text {st }}$ ed, 2003).

Zhang, Qiong, 'The Legislative Affairs of the State Council Introduces FOI Regulations' (in Chinese) (Press Release, 24 April 2007).

Zhang, Ruiqian, 'Strengthening Guidance of Public Opinion to Improve the Ruling Capability' (in Chinese) Yanzhao Evening (Shijiangzhuang) 15 December 2008, A3.

Zhang, Wenjie, 'Introduction on Shanghai Major Construction Projects in 2008' (in Chinese) (Press Release, 19 March 2008).

Zhang, Xuan, Su Sued against the Personnel Management Bureau for Not Disclosing Government Information (in Chinese) (2005) Shanghai No 2 Intermediate People's Court <http://www.shezfy.com/spyj/alpx_view.aspx? id= $2905>$ at 11 May 2008.

Zhang, Yinghui, 'The Incapability of Controlling the Transmission of SMS Messages and the Solutions' (in Chinese) (2008) 1 News Window 104-6.

Zhang, Youyi, 'A Journalist Protects His Right to Interview according to FOI Regulations' (in Chinese) Legal Daily (Beijing) 23 March 2008, 2.

Zhao, Lei and Su, Yongtong, 'Many Doubts about Government Information Disclosure' (in Chinese) Southern Weekend (Guangzhou) 8 May 2008, A04.

Zhao, Wenming, 'Reflecting on the First Lawsuit after FOI Regulations Took Effect' (in Chinese) Legal Daily (Beijing) 6 May 2008, 8. 
Zhao, Yihai and Xu, Nan, 'Is Disclosure of the Details regarding the Issue of the Olympics Commemorative Currency Counted as Secret Divulgence?' (in Chinese) Southern Weekend (Guangzhou) 6 November 2008, C20.

Zhao, Zhengqun, 'Discussion of Anti-Corruption through Openness in Government Affairs' (in Chinese) (2001) 6 Theory and Modernisation 51-6.

Zhao, Ziyang, 'Take Strides along the Road to Socialism with Chinese Characteristics' (in Chinese) (Speech delivered at the $13^{\text {th }}$ National Congress of the CPC, Beijing, 25 October 1987).

Zhen, Henan, 'Shortcomings for FOI: A Citizen's Fight with the Planning Bureau' (in Chinese) Procuratorial Daily (Beijing) 4 August 2008, 7.

Zheng, Lei, 'Enacting and Implementing Open Government Information Regulations in China: Motivations and Barriers' (Paper presented at the First International Conference on Theory and Practice of Electronic Governance, Macao, 10-13 December 2007).

Zhong, Lian, The Shenzhen Justice Bureau Was Sued for Replying to an FOI Request via a Private Email (in Chinese) (2008) $21^{\text {st }}$ Centuries Net <http://www.21cbh.com/HTML/2008/8/26/HTML_X87778CRQ1PG.html> at 22 October 2008.

Zhou, Enlai, Selected Works of Enlai Zhou (in Chinese) (1 $\left.{ }^{\text {st }} \mathrm{ed}, 1984\right)$.

Zhou, Hanhua, 'FOI Regulations Will Bring about Six Changes' (in Chinese) People's Daily (Beijing) 14 February 2007, 13.

, 'Open Government in China: Practice and Problems' in Ann Florini (ed), The Right to Know: Transparency for an Open World (2007) 92-115.

, 'Regulation on Government Information Publication in China: Practice, Problems and Prospect' (Speech delivered at Conference on China Policy Dialogue 2005, Columbia, 1 June 2005).

, 'Significance and Features of Introducing FOI Legislation in China' (in Chinese) (2007) 6 China Today Forum 29-30.

(2008) 7 E-Government 15-17.

, 'The Legislative History of FOI Regulations in China' (in Chinese) (Speech delivered at the Second Summit on E-Government, Beijing, 28 June 2007).

, Academic Draft of FOI Regulations (in Chinese) $\left(1^{\text {st }} \mathrm{ed}, 2003\right)$. 
ed, 2007).

, Government Governance and Administrative Law (in Chinese) $\left(1^{\text {st }}\right.$

, Speech delivered at Seminar on the Challenges and Possibilities for Government Information Disclosure, Beijing, 25 June 2008.

March 2007.

, Speech delivered at Seminar on the FOI Regulations, Beijing, 17

Zhou, Kai, 'The Proposed Shanghai Maglev Construction Project Available for Public Opinion' (in Chinese) China Youth Daily (Beijing) 14 January 2008, 7.

Zhou, Yunfan, 'Analysis of FOI Law-Making Activities in China' (in Chinese) (2005) 6 Journal of Jinan University 54-61.

Zhu, Hongjun, "“I Will Fight to Death for Your Right to Say It" - Full Transcripts of Public Hearings about the Xiamen Paraxylene Project Environmental Impact Assessment' (in Chinese) Southern Weekend (Guangzhou) 20 December 2007, $\mathrm{A} 02$.

, 'The Xiamen Government's Consideration of Public Participation' (in Chinese) Southern Weekend (Guangzhou) 20 December 2007, A01.

Zhu, Huaxin et al, 'Analysis Report on Public Opinions on the Internet in China in 2007' (in Chinese) (2008) 2 Today's Mass Media 31-40.

Zhu, Songyan, 'Analysis of and Thoughts on the Current Situation of FOI in China' (in Chinese) (2003) 3 Expanding Horizons 31-33.

Zimmerman, James, China Law Deskbook ( $2^{\text {nd }}$ ed, 2005).

Zuo, Qiuming, Chunqiu Zuozhuan. See http://www.guoxue.com/jinbu/13jing/cqzz/ cqzz_ML.htm. 


\section{Cases}

Forests Survey Inspection Request Case, 1 KCCR 176, 88 Hun-Ma 22, September 4, 1989.

Gao v Ninghai County People's Government (2006) 3 The People's Court of Fenghua City (The First Instance).

Goldberg v Kelly, 397 US 254, 267-68 (1970).

Inter-American Court of Human Rights, Claude Reyes et al v Chile Judgment of September 19, 2006.

Jinsong Hao $v$ The Shaanxi Forestry Department (2008) 1 The Lianhu District People's Court of Xi'an.

Jordan v United States Dept of Justice, 591 F 2d 753, 772-3 (1978).

Kenedi v Hungary No 31475/05, 26.5.2009.

Lian $v$ The General Team of Transportation Police (2005) 165 The Shanghai No 2 Intermediary People's Court (The Second Instance).

Liying Gao v The Beijing Sijiqing Township Government (2008) 201 The Haidian District People's Court of Beijing (The First Instance).

Military Secret Leakage Case KCCR 64, 89Hun-Ka104, February 25, 1992.

S.P. Gupta v President of India and others etc. AIR 1982 SC 149.

Su $v$ Shanghai Huangpu District Personnel Bureau (2005) 72 The Shanghai No 2 Intermediary People's Court (The Second Instance).

Társaság a Szabadságjogokért v Hungary No 37374/05, 14.4.2009.

Yuhua Chen v The Beijing Municipal Public Security Bureau (2008) 155 The Dongcheng District People's Court of Beijing (The First Instance). 


\section{Legislation}

Administrative Appeals Tribunal Act 1975 (Australia)

Administrative Decisions (Judicial Review) Act 1977 (Australia)

Administrative Litigation Law 1989 (China)

Administrative Penalty Law 1996 (China)

Administrative Permission Law 2003 (China)

Administrative Procedure Act, 5 USC (1946).

Administrative Reconsideration Law 1999 (China)

Administrative Supervision Law 1997 (China)

American Convention on Human Rights

Anti-trust Law 1993 (China)

Archives Law 1987 (China)

Audit Law 1995 (China)

Civil Procedure Law 1982 (China)

Civil Servant Law 2005 (China)

Constitution 1982 (China)

Copyright Act, 17 USC (1994)

Criminal Law 1997 (China)

Criminal Litigation Law 1996

Directive (EC) No 98/2003 of 17 November 2003 on the Re-use of Public Sector Information [2003] OJ L 345/90.

Federal Transparency and Access to Public Government Information Law 2002 (Mexico)

Federal Register Act, 44 USC (1935)

Freedom of Information Act 2000 (UK)

Freedom of Information Regulations 2007(China) 
Freedom of Information Rules of the Archives Bureau 2008 (China)

Freedom of Information Rules of the Commission of National Defence and Science Industry 2007 (China)

Freedom of Information Rules of the Ministry of Education 2008 (China)

Freedom of Information Rules of the National Bureau of Tax 2008 (China)

Freedom of Information Rules 2004 (Shanghai)

General Standards on Physical Examinations concerning the Employment of Civil Servants (for Trial) 2005 (China)

Government Information (Public Access) Act 2009 (NSW)

Green Paper on Public Sector Information Com (1998) 585

Interim Measures for Public Participation in Environmental Impact Assessment 2005 (China)

Interim Rules on Freedom of Information of the Bureau of Intellectual Property 2008 (China)

Interim Rules on Freedom of Information on the Government Website of the Commission of National Defence and Science Industry 2007 (China)

Interim Rules on the Tenure System of Leading Cadres of the Party and Government 2006 (China)

International Covenant on Civil and Political Rights

Law on Administrative Penalties for Public Security 2005

Law on the Prevention and Cure of Infectious Diseases 1989 (China)

Law on the Protection of State Secrets 1988 (China)

Legislation Law 2000 (China)

Measures for the Administration of Relief for Vagrants and Beggars without Assured Living Sources in Cities 2003 (China)

Ombudsman Act 1976 (Australia)

Organic Law of the Urban Residents Committees 1989 (China)

Organic Law of the Villagers ' Committee 1998 (China) 
Organic Law of the Villagers' Committees (for trial) 1987 (China)

Paperwork Reduction Act 44 USC (1995)

Police Law 1995 (China)

Prevention and Cure of Infectious Diseases Law 1989 (China)

Provisional Regulations on the Open Selection of Leading Cadres of the Party and Government 2004 (China)

Price Law 1997 (China)

Property Law 2007 (China)

Regulations on Preparedness for and Response to Emergent Public Health Hazards 2003 (China)

Rules on the Intercommunication System of Leading Cadres of the Party and Government 2006 (China)

Regulations on the Work of Selecting and Appointing Leading Party and Government Cadres 2002 (China)

Supreme Court's Explanation on Several Questions Related to the Implementation of the Administrative Litigation Law 1989 (China)

Supreme Court's Several Issues Related to the Trial of Civil Dispute Cases Related to Restructuring of Enterprises Provisions 2003 (China)

Trade Union Law 1992 (China)

Universal Declaration of Human Rights 


\section{Policy documents}

Decision of Administrative Reconsideration Made by the Zhuhai People's Government No 8 [2006] of the Zhuhai People's Government

Decision of the CPC Central Committee on Strengthening the Building of the Party's Ruling Capability No 18 [2004] of the Central Committee of the CPC

Decision of the State Council on Strengthening Administration by Law in the Municipal and County Governments No 17 [2008] of the State Council

Decision of Pushing forward Administration by Law in an All-Round Way No 23 [1999] of the General Office of the State Council

Guidance on the Leading Group of National Informatisation for China's EGovernment Construction No 17 [2002] of the General Office of the CPC Central Committee

Guidance on Building E-Government No 17 [2002] of the General Office of the CPC Central Committee

Implementation Outline for Pushing forward Administration by Law in an AllRound Way No 10 [2004] of the General Office of the State Council

Notice on Enforcement Outline for the Establishment and Improvement of a Corruption Punishing and Prevention System with Equal Attention Paid to Education, Institutions and Supervision No 3 [2005] of the Central Committee of the CPC

Notice on Comprehensively Implementing Openness in Village Affairs and Democratic Management No 9 [1998] of the General Office of the CPC Central Committee

Notice on Declassifying Death Tolls from Natural Disasters and the Related Information No 116 [2005] of the Ministry of Civil Affairs

Notice on Disclosure of Death Tolls and Related Natural Disasters Information 2005 (China)

Notice on Enhancing the Construction of Grassroots Organisations in the Rural Areas No 10 [1994] of the General Office of the CPC Central Committee

Notice on Further Governing the Abusive Distribution of Party and Official Publications by Taking Advantage of Their Position and Power to Alleviate Primary Levels and Farmers' Burden No 19 [2003] of the General Office of the CPC Central Committee 
Notice on Further Promoting Openness in Government Affairs in All Administration by Industry and Commerce Agencies No 154 [2000] of the General Office of the State Administration for Industry and Commerce

Notice on Further Promoting Openness in Government Affairs No 12 [2005] of the General Office of the CPC Central Committee

Notice on Implementing Openness in Police Affairs in All Public Securities Agencies No 43 [1999] of the Ministry of Public Security

Notice on Preparing for the Implementation of FOI Regulations No 54 [2007] of the General Office of the State Council

Notice on Promoting Openness in Government Affairs around All Government Agencies at the Township Level No 25 [2000] of the General Office of the CPC Central Committee

Notice on Rules on Major Responsibilities, Divisions and Personnel Quotas of the General Office of the State Council No 60 [2008] of the General Office of the State Council

Notice on Standardising the Quotas of Assistants and Deputy Secretary-Generals at the Local Level No 3 [2009] of the Organisation Department of the CPC Central Committee

Notice on Suggestions for Enforcing 2006's Legislation Work and 2006's Legislative Plan No 2 [2006] of the General Office of the State Council

Notice on Suggestions for Further Implementing 'Eight Openness Items' concerning Civilised Tax Collection in All Tax Agencies No 144 [2000] of the State Administration of Taxation

Notice on the Pilot Project for Developing the Administrative Reconsideration Committee in Several Provinces and Special Municipalities No 71 [2008] of the Legislative Affairs Office of the State Council

Notice on Training Sessions for FOI Regulations [2007] of the Legislative Affairs Office of the State Council

Opinions on Strengthening the Work of the Chinese People's Political Consultative Conference No 5 [2006] of the CPC Central Committee

Overall Framework of National E-Government No 2 [2006] of the State Council Informatisation Office

Resolution on Certain Questions in the History of Our Party since the Founding of the People's Republic of China (1981) 
Resolution on Major Issues regarding the Building of a Harmonious Socialist Society No 19 [2006] of the Central Committee of the CPC

Rules on the Scope of State Secrets and Secrecy Levels in the Work of Civil Affairs No 17 [2000] of the Ministry of Civil Affairs

Several Suggestions on the Implementation of China's FOI Regulations No 36 [2008] of the General Office of the State Council

Suggestions on Fully Establishing and Enhancing Openness in Village Affairs and Democratic Management No 17 [2004] of the General Office of the CPC Central Committee

Suggestions on Further Promoting Openness in Government Affairs No 69 [2006] of the State Administration of Taxation

Suggestions on Strengthening Exploitation and Use of Information Resources No 34 [2004] of the General Office of the CPC Central Committee

Working Rules of the State Council No 14 [2008] of the State Council 